\title{
Az Arabidopsis E2FB transzkripciós faktor funkcionális jellemzése
}

\author{
Ph.D. értekezés
}

Készítette: Öszi Erika

Témavezetö: Dr. Magyar Zoltán

Szegedi Biológiai Kutatóközpont

Növénybiológiai Intézet Növényi Morfogenezis Szabályozása Csoport

és

Szegedi Tudományegyetem Természettudományi és Informatikai Kar

Biológia Doktori Iskola

Szeged

2020 


\section{Tartalomjegyzék}

RÖVIDÍTÉSEK JEGYZÉKE.................................................................... 3

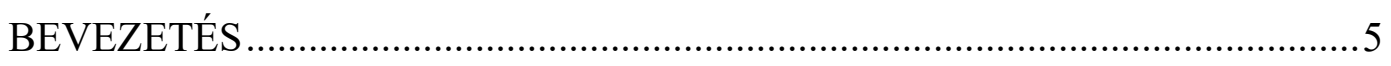

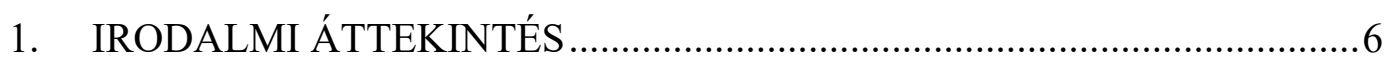

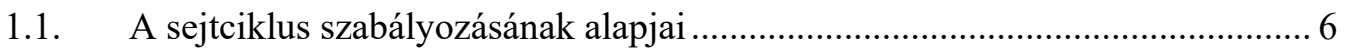

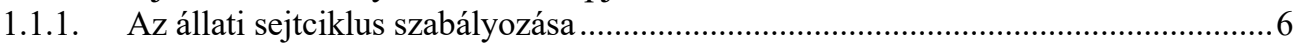

1.1.2. A növényi sejtciklus szabályozása ........................................................................9

1.1.3 Az evolúciósan konzerválódott retinoblasztóma-E2F transzkripcionális szabályozás

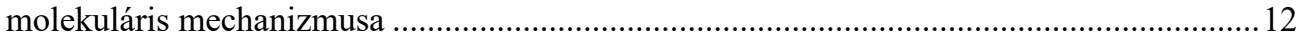

1.1.4. Az E2F transzkripciós faktorok felépítése és a sejtciklus során betöltött szerepe

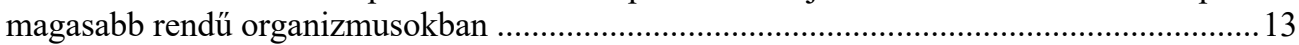

1.1.5 Az RB tumorszupresszor szerkezete és funkciója …………………………….....15

1.1.6. A növényi RBR/E2F szabályozási mechanizmus...................................................17

1.2. A levél, mint a növényi szervfejlődés modellje........................................... 20

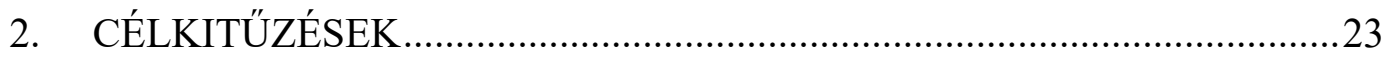

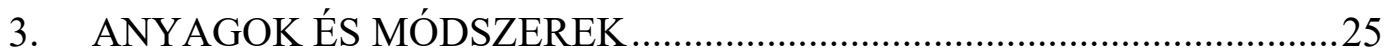

3.1. Plazmid konstrukciók és transzgenikus növények generálása.......................... 25

3.1.1. Fluoreszcens taggel jelölt E2F transzlációs konstrukciók és transzgenikus

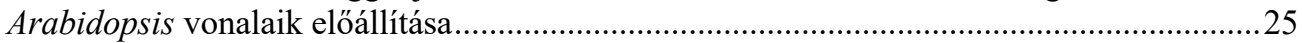

3.1.2. p35S:HA-E2FB-DPA ${ }^{\mathrm{OE}}$ koexpresszáló transzgenikus Arabidopsis vonalak

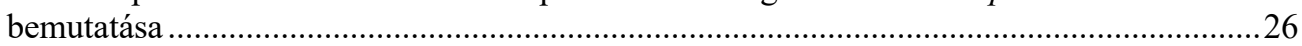

3.1.3. Deléciós E2F konstrukciók elöállítása...............................................................22

3.1.4. E2F T-DNS inszerciós funkcióvesztéses mutánsok...............................................27

3.1.5. Mesterséges mikroRNS konstrukciók készítése az RBR csendesítésére, és

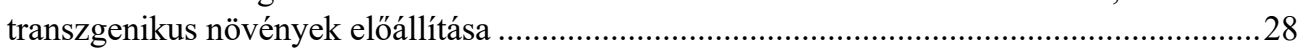

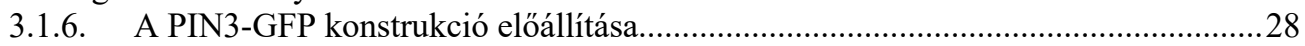

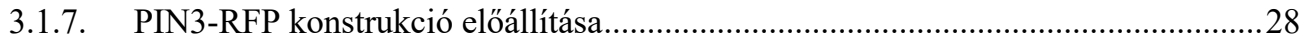

3.2. Arabidopsis thaliana növények transzformációja virág merítéses

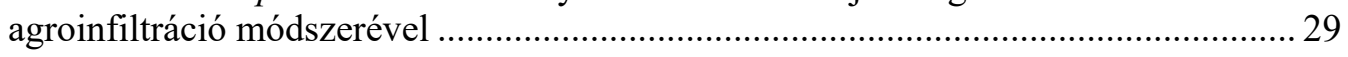

3.3. Nicotiana benthamiana növényi levelek agroinfiltrációja ............................. 29

3.4. In vitro növény kultúrák és kísérleti növényi anyag előállítása ...................... 29

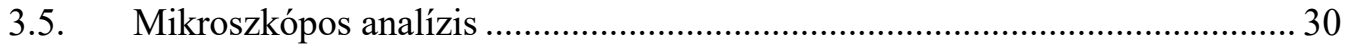

3.5.1. Levél agaróz lenyomat készítés ……………......................................................30

3.5.2. Gyökércsúcs Lugol festése...........................................................................

3.5.3. Levél és gyökér szövetek propídium-jodid festése és konfokális mikroszkópos

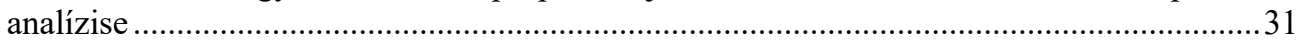

3.5.4. Gyökerek EdU (5-Etinil-2-DeoxiUridin) festése.......................................................31

3.5.5. A különböző fluoreszcens tagek konfokális lézermikroszkópos analízise ................31

3.6. A levél kinematikai jellemzése ................................................................. 32

3.7. A sejtek DNS tartalmának meghatározása áramlási citometriával....................... 33

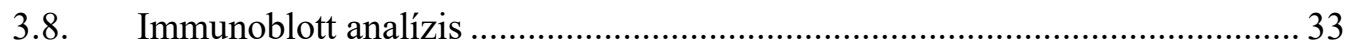

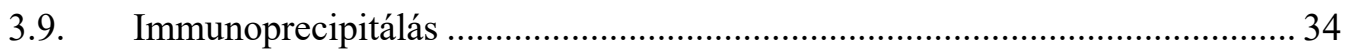

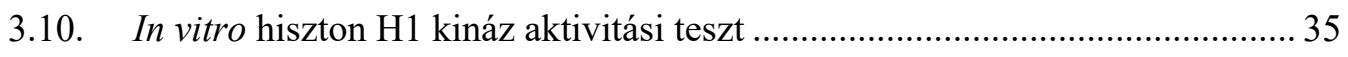

3.11. Membrán preparáció differenciál centrifugálással ....................................... 35

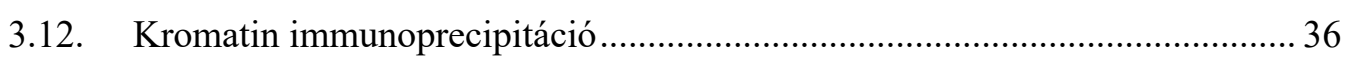

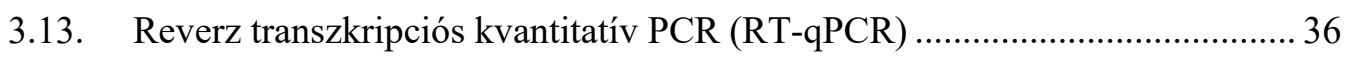


3.14. Termikus aszimmetrikus átfedő PCR (TAIL-PCR)

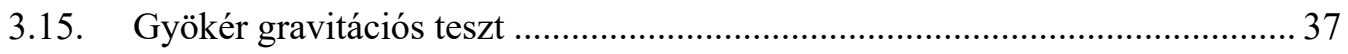

3.16. Agroinfiltrált Nicotiana dohánylevél és transzgenikus Arabidopsis növények

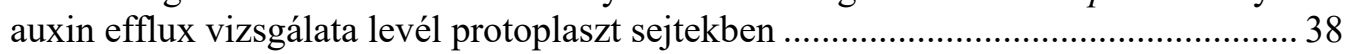

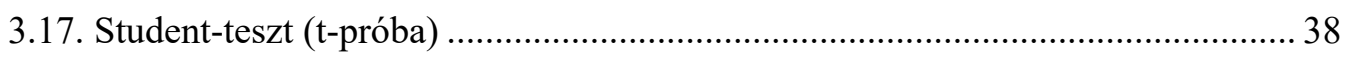

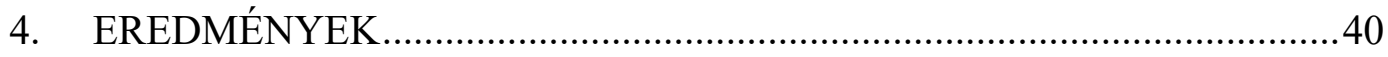

4.1. Az Arabidopsis E2FB fehérje megjelenése a fejlődő levél epidermiszében ... 40

4.1.1. Az E2FB túltermeltetése gátolja a sejtosztódást és a levél növekedését ..................41

4.1.2. Az E2FB túltermeltetése gátolja a sejtciklus gének kikapcsolódását a levélfejlődés

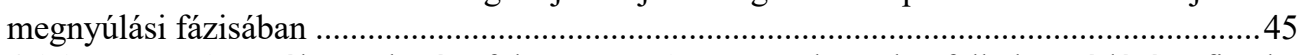
4.1.3. Az E2FB túltermeltetése fokozza az E2FB-RBR komplex felhalmozódását a fiatal, még osztódó levélben, amely feltehetően meggátolja és késlelteti a sejtek osztódásba

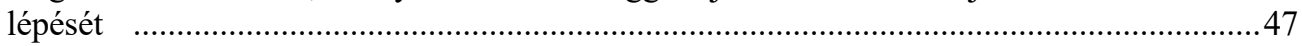

4.1.4. Az E2FB funkció hiánya serkenti a merisztematikus levélsejtek osztódását a fejlődő

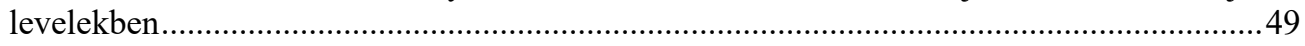

4.1.5. Az E2FA és E2FB képesek egymást kompenzálni, de eltérő molekuláris

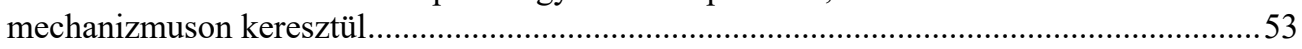

4.1.6. Az E2FB közvetlenül szabályozza a müködéséért felelös $R B R$ és $C Y C D 3 ; 1$.............

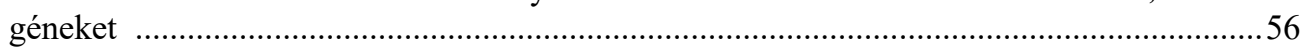

4.1.7. Az E2FB és a DPA együttes túltermeltetése nem vezet hiperproliferációhoz a

fejlödö levelekben ..................................................................................................57

4.1.8. Az E2FB az RBR fehérjével komplexben korlátozza a zárósejt merisztemoidok

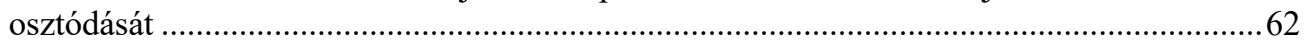

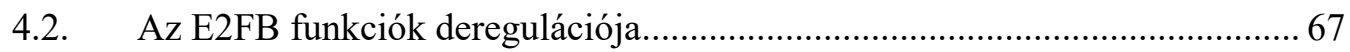

4.2.1. Az Arabidopsis RBR funkció gátlása mikroRNS segítségével specifikusan az

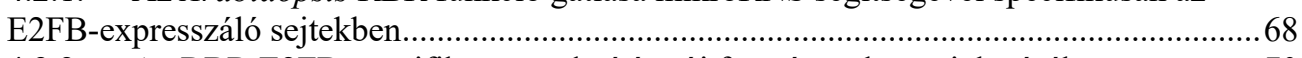

4.2.2. Az RBR E2FB-specifikus csendesítése új fenotípusok megjelenéséhez vezetett....70

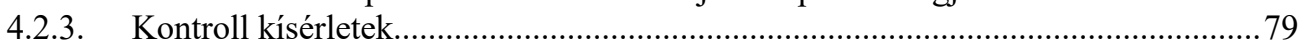

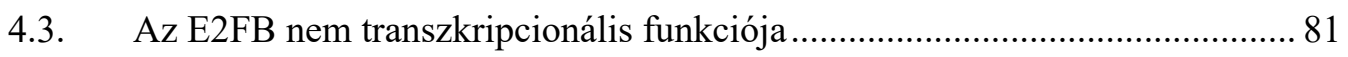

4.3.1. Az E2FB fehérje membrán-lokalizációja............................................................. 81

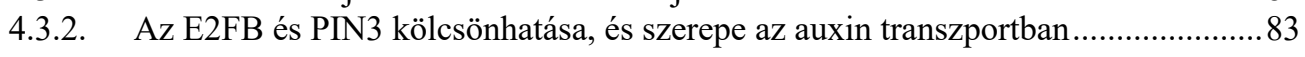

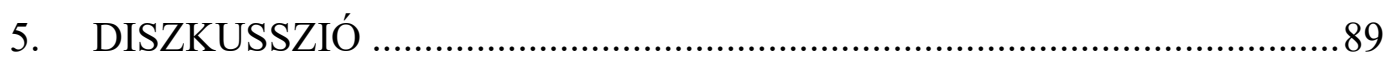

5.1. Az E2FB a levélben fejlődési stádiumtól függő módon aktivátor és represszor

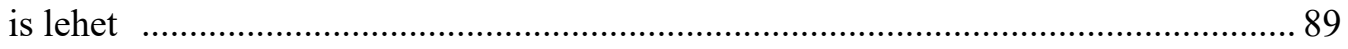

5.2. Az E2FB levélsejttípustól függően aktivátor és represszor is lehet ................ 92

5.3. Az E2FB és az E2FA egymást ellentétesen szabályozzák, ami a kompenzációs

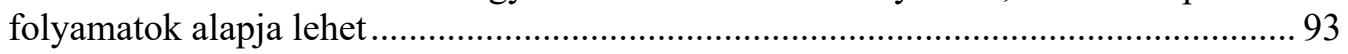

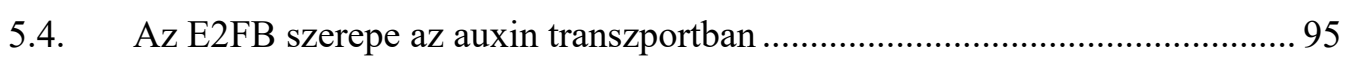

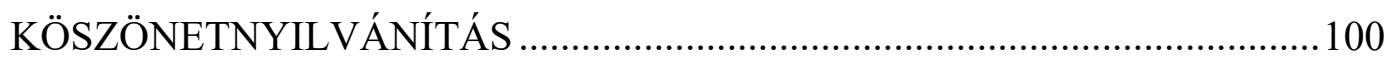

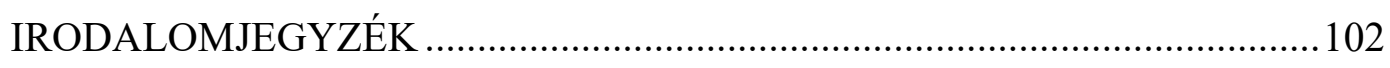

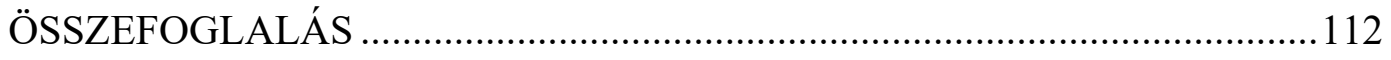

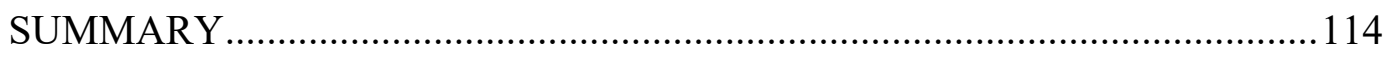

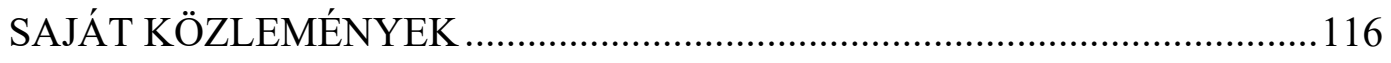

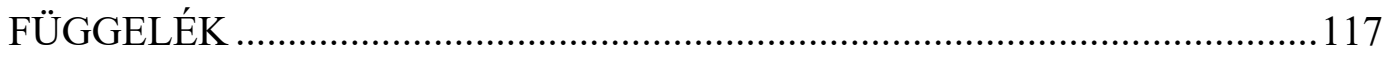




\section{RÖVIDÍTÉSEK JEGYZÉKE}

1/2 GM 1/2 Murashige and Skoog tápanyag tartalmú csírázási médium (Germination Medium)

amiRBR RBR-specifikus mikroRNS (Artificial MIcroRNA)

AP adaptor protein komplex (Adaptor Protein complex) - a dolgozatban a komplex több fajtája is említésre kerül

AP2S adaptor protein komplex 2 kis alegysége (Adaptor 55 Protein 2 Small Subunit)

BA benzoesav (Benzoic Acid)

CAK CDK aktiváló kináz (Cyclin-dependent kinase Activating Kinase)

CDK ciklin-függő kináz (Cyclin-Dependent Kinase) - a dolgozatban több fajtája is említésre kerül, amelyeket az 1. táblázat foglal össze

CHC klatrin nehéz lánc fehérje (Clathrin Heavy Chain)

ChIP kromatin immunprecipitáció (CHromatin ImmunoPrecipitation)

DAG a csírázástól eltelt napok száma (Days After Germination)

DEL növényi E2F alcsalád (DP-E2F-Like 1-3)

DP dimerizációs partner (Dimerization Partner) - a dolgozatban több fajtája is említésre kerül

DR5 szintetikus auxinra érzékeny promóter

DREAM transzkripcionális komplex (DP-RBF-E2F-And-MYB komplex)

$\mathrm{E} 2 \mathrm{~F}$ adenovírus E2 Faktor - a dolgozatban több fajtája is említésre kerül

EdU 5-Etinil-2-DeoxiUridin

G0 a sejtciklus nyugalmi fázisa (Gap-0)

G1 a sejtciklus 1. fázisa (Gap-1)

G2 a sejtciklus 2. fázisa (Gap-2)

GFP zöld fluoreszcens fehérje (Green Fluorescent Protein)

H1 Hiszton 1 fehérje

HA emberi influenza HemAgglutinin

IAA indol-3-ecetsav (Indole-3-Acetic Acid)

INK4 a CKI-k egy fajtája (INhibitors of CDK4)

IP ImmunoPrecipitáció

KRP Kip-rokon fehérjék (Kip-Related Protein) - a dolgozatban több fajtája is említésre kerül

M a Mitózis fázisa

MCM3 sejtciklus szabályozó (MiniChromosome Maintenance Complex Component 3)

MTF Membrán kötött Transzkripciós Faktor

ORC2 sejtciklus S fázisát szabályozó fehérje (Origin Recognition Complex 2) 
p107 emlös retinoblasztóma-rokon zsebfehérje, tumorszupresszor

p130 emlős retinoblasztóma-rokon zsebfehérje, tumorszupresszor

p13 ${ }^{\mathrm{SUC1}} \quad$ élesztő sejtciklus szabályozó fehérje

p35S dohány mozaik vírus promóter

PCNA1 S fázis-specifikus E2F célgén (Proliferating Cellular Nuclear Antigen 1)

PCR polimeráz láncreakció (Polymerase Chain Reaction)

PIN auxin efflux csatorna (Peptidyl-prolyl cis-trans Isomerase NIMA-interacting) - a dolgozatban több fajtája is említésre kerül

QC nyugvó centrum (Quiescent Center)

qPCR valós idejü kvantitatív PCR (Quantitative Polymerase Chain Reaction)

RB RetinoBlasztóma fehérje - a dolgozatban több fajtája is említésre kerül

RBR növényi retinoblasztóma-rokon fehérje (RetinoBlastoma-Related protein)

RFP piros fluoreszcens fehérje (Red Fluorescent Protein)

RT-qPCR reverz transzkripciós kvantitatív PCR (Quantitative Reverse Transcription PCR)

S fázis a DNS Szintézis fázisa

SDS-PAGE nátrium -dodecil-szulfát poliakrilamid gélelektroforézis (Sodium Dodecyl-Sulfate PolyAcrylamide Gel Electrophoresis)

T-DNS Transzfer DNS

t-Z Transz-Zeatin

TAIL-PCR termikus aszimmetrikus átlapolt PCR (Thermal Asymmetric InterLaced PCR)

TF Transzkripciós Faktor

TMM a zárósejt merisztemoid sejtekben müködő transzkripciós faktor (Too Many Mouth)

WT $\quad$ vad típusú növények (Wild Tipe)

YFP sárga fluoreszcens fehérje (Yellow Fluorescent Protein) 


\section{BEVEZETÉS}

Napjainkban a növénybiológiai és mezőgazdasági kutatások komoly kihívások elé néznek. A globális felmelegedés kedvezőtlen éghajlati változásokhoz vezet, amely megnehezíti a mezőgazdasági termelést. Ráadásul, az emberiség létszáma folyamatosan gyarapodik, miközben a termőterületek nagysága tovább már nem növelhető, azaz olyan megoldásokra van szükség, amelyekkel nemcsak fenn lehet tartani a mezőgazdasági termelés jelenlegi magas szintjét, de az növelhetö is lesz. Fontos, hogy a tudomány lépést tartson ezekkel a megnövekedett igényekkel. Ezért lényeges, hogy megértsük a növények növekedését és fejlödését szabályozó molekuláris folyamatokat, hogy a környezeti tényezőknek ellenállóbb, magasabb terméshozamot és biomasszát produkáló növényeket tudjunk előállítani.

A növények fejlődése, növekedése és új szerveik kialakulása döntően a sejtosztódás szabályozásán alapszik. Szemben az állatokkal, a növények esetében nemcsak a fejlődésgenetikai program, de a környezeti változások is meghatározzák a sejtosztódás mértékét, valamint a kialakuló növények méretét és formáját is. A fejlődő növényekben az osztódások helye és ideje komplex szabályozási mechanizmusok ellenőrzése alatt áll, ezek pontos múködése azonban még nem teljesen ismert. Az osztódások alakulásában meghatározó szerepet játszanak a növényi hormonok, különösen az auxin, amely koncentrációfüggő módon képes befolyásolni az osztódások aktivitását. Az osztódási ciklusba történő be- és kilépést egy evolúciósan konzerválódott transzkripcionális mechanizmus szabályozza, amit a benne részt vevő komponensekröl E2F-RB szabályozásnak nevezünk. A retinoblasztóma $(R B)$ volt az első azonosított sejtburjánzást gátló gén, amelyet emlős sejtekből izoláltak, míg az E2F (ADENOVÍRUS E2 FAKTOR) transzkripciós faktort az RB-vel komplexet formáló képessége alapján azonosították. A növények és állatok életmódjának és fejlödésének nyilvánvaló különbözősége ellenére ez a szabályozási mechanizmus meglepően jól konzerválódott. A növényi molekuláris fejlödésbiológiai kutatások modellnövénye, az Arabidopsis thaliana egyetlen RB-rokon molekulával rendelkezik (RETINOBLASZTÓMA-ROKON, röviden RBR), ami az E2F transzkripciós faktorokon keresztül szabályozza a sejtek osztódását. Központi szerepet játszik ebben a szabályozásban a három Arabidopsis E2F transzkripciós faktor (E2FA, E2FB és E2FC). Az E2FB aktiválja a sejtosztódásba lépéshez szükséges gének müködését, míg az RBR-rel komplexben gátolja öket. A legújabb eredmények alapján ez az egyszerü és éppen ezért attraktív modell sokkal komplexebbé vált. A különböző E2F-ek nemcsak egymással átfedő, hanem különbözö, egyedi funkciókat is betöltenek, ezen felül az E2F-ek szövet- és szervspecifikus funkcióval is rendelkezhetnek. Az E2F transzkripciós faktorok müködésének mélyebb megismerése közelebb visz bennünket a növekedés és fejlődés hátterében meghúzódó folyamatok megértéshez, amely a közeljövőben a gazdaságilag hasznos növények nemesítési programjai számára kínálhat új lehetőséget. 


\section{IRODALMI ÁTTEKINTÉS}

\subsection{A sejtciklus szabályozásának alapjai}

Minden élőlény építőkövei a sejtek, amelyek osztódási és differenciálódási folyamatok révén szöveteket és szerveket hoznak létre. A sejtosztódásnak köszönhetően az emberi szervezetben percenként mintegy 300 millió új sejt születik, annak ellenére, hogy az emberi szervek és szövetek már az embrionális fejlődés során kialakulnak. Az új sejtek az elöregedett és elhasználódott sejtek helyébe lépnek, és a már meglévő szervek megújítása a feladatuk. A növények életciklusa az állatokétól lényegesen eltér. Szerveik jelentős része ugyanis az embrionális fejlődés után alakul ki, és a teljes életciklus folyamán képesek új szerveket létrehozni. A sejtosztódás szabályozása a növekedés és fejlődés egyik fontos komponense, de nem az egyedüli mozgatórugója. Az újonnan létrejött sejtek differenciálódása és növekedése épp úgy meghatározó szerepet játszik a szövetek és szervek kialakulásában és müködésében. Tehát az osztódás és a differenciálódás egymással szoros kapcsolatban álló folyamatok, amelyek között az egyensúlyt a környező sejtek által kibocsátott extracelluláris jelek (mitogén jelek, növekedési faktorok, és hormonok) valamint a környezeti faktorok együttesen befolyásolják.

A szomatikus (testi) sejtek osztódását mitózisnak nevezzük, mely egy jól meghatározott, evolúciósan konzervált folyamaton, a sejtcikluson keresztül szabályozódik, ahol az osztódó sejt egymást szigorúan követő fázisokon megy keresztül. A sejtciklus első három fázisát együttesen interfázisnak nevezzük, melynek során megduplázódik a sejtek DNS tartalma, majd a sejt a mitózis (profázis - metafázis - anafázis - telofázis) során kettéosztódik. Az interfázisban a sejtek a Gap-1 (G1) fázisban növekednek, elérik az osztódásba lépéshez szükséges sejtméretet, tápanyagot és energiát gyüjtenek. A sejtek belépve a sejtciklusba először a DNS-szintézis fázisába (röviden S fázis) érkeznek, ahol a kromoszómák DNS állománya kettőződik meg, majd ezt követően a Gap-2 fázisban (G2) a sejtek felkészülnek a megduplázódott DNS kópiák egyenlő mértékủ szétosztására a leánysejtekbe. A sejtciklus kontroll pontjaiban ellenőrzésre kerül, hogy a folyamatok (DNS replikáció, kromoszómák szegregációja) hibátlanul végbementek-e, és beléphet-e a sejt a mitózis következő szakaszába. A mitózis (M) fázisa alatt a megduplázódott génállomány egyenlő mértékben kettéosztódik, és bekövetkezik a citokinézis, a leánysejtek szétválása (Fehér és Magyar, 2015).

\subsubsection{Az állati sejtciklus szabályozása}

A sejtciklus szabályozás központi elemei a CIKLIN-FÜGGÖ KINÁZ enzimek (angol elnevezésük CYCLIN-DEPENDENT KINASE, röviden és a későbbiekben CDK); azok a szerin/treonin kinázok, amelyek szabályozó alegységei a sejtciklus során periodikusan megjelenő 
ciklinek (innen ered az elnevezésük is). Egyes CDK-k és ciklinek a sejtciklus során fázisspecifikusan formálódnak (Morgan, 1995).

A sejtciklus kutatások genetikai modellorganizmusai, a Saccharomyces pombe (hasadó élesztő) és a Saccharomyces cerevisiae (sarjadzó élesztö) esetében egyetlen, ciklin-kötő PSTAIRE motívummal (konzerválódott aminosav szekvencia) rendelkező CDK található (a hasadó élesztőben ez CDC2, míg a sarjadzó élesztőben CDC28 néven lett ismert), amely az egész sejtciklus szabályozásáért felelős. Ez az egy CDK elengedhetetlen az élesztő osztódásához (Gutiérrez-Escribano és Nurse, 2015; Harashima, Dissmeyer és Schnittger, 2013). A több tagból álló és eltérő funkcióval rendelkező CDK család a metazoáknál (többsejtűeknél) jelent meg először. Az állati CDK1 (az élesztő CDC2/CDC28 funkcionális és strukturális megfelelője) feladata döntően a sejtciklus M fázisának a szabályozása, míg az interfázisú CDK-k, mint a CDK2, CDK4 és CDK6 az osztódásba lépést, és az S fázis folyamatait szabályozzák (1. táblázat). Az interfázisú CDK-k nem képesek helyettesíteni az élesztő CDC2/CDC28-at (CDK1), egyrészt mert eltérő ciklin-kötő motívummal rendelkeznek, másrészt csak kismértékü homológiát mutatnak a CDC2/CDC28-cal. A CDK2, amely PSTAIRE motívummal rendelkezik emberben, egérben, Xenopus-ban (karmosbékában), és Drosophila-ban (muslicában), és PSTCLRE motívummal a Caenorhabditis-ben (fonalféregben), nemcsak a G1/S, hanem a G2/M fázisátmenetben is szerepet játszik (1. ábra A; Guadango és mtsai., 1996). A későbbi kutatások azonban kimutatták, hogy az interfázisú CDK2, -4 és -6 kinázok szerepe nem esszenciális a sejtciklus elörehaladásához, míg a CDK1 nélkül nincs sejtosztódás, az élesztő CDC2/CDC28hoz hasonlóan (Santamaría és mtsai., 2007). Hiányában az embrionális sejtek sem képesek az osztódásra. Bizonyítja ezt, hogy a $c d k 2$ cdk4 cdk6 hármas knockout mutáns egerekben az embrionális sejtosztódás nem áll le és csak a fejlödés egy kései stádiumában halnak el. Ennek oka lehet, hogy az interfázisú CDK-k szerepe feltehetően szövetspecifikus, és a differenciálódási folyamatokban vesznek részt. Ezzel szemben a $c d k l$ knockout egerek az embriogenezis rendkívül korai, osztódási szakaszában elpusztulnak, bizonyítva a CDK1 kulcsfontosságát a sejtosztódás során (Harashima, Dissmeyer és Schnittger, 2013).

A CDK-k irányítják a sejtciklus fő lépéseit, de aktivitásukat komplex folyamatok szabályozzák. A CDK-k maximális aktivációjához a ciklin kötődés mellett az aktív centrum közelében lokalizálódó treonin aminosav (röviden T) foszforilációja is szükséges (ami a CDK1 esetében a 161-es, míg a CDK2-nél a 160-as pozícióban található), amelyet a CDK-AKTIVÁLÓ KINÁZ (CAK) hajt végre. Ez a foszforiláció jelentősen, akár háromszázszorosára is megnövelheti a kináz affinitását a szubsztrát fehérje irányába. Ezzel szemben a 14-es pozíciójú treonin (T14) és a 15ös tirozin (Y15) foszforilációja gátolja a CDK2 és CDK1 enzimek aktivitását. A WEE1 (név eredete: a skót wee szóból származik, jelentése kicsi) és MYT1 (MEMBRANE ASSOCIATED TYROSINE / THREONINE 1) kinázok felelősek a T14/Y15 helyek foszforilációjáért. Az inhibitor foszfát csoportok eltávolítását a CDC25 (CELL DIVISION CYCLE 25) foszfatáz végzi 
(Vigo és mtsai., 1999; Perry és Kornbluth, 2007). A CDK-k gátlását okozhatják a CDK inhibitorok (CKI) is, amelyeken belül két csoportot különböztetünk meg: a CDK4 inhibitorokat (INHIBITOR OF CDK4 - INK4), melyek a CDK4 mellett a CDK6 inhibitorai is, és a CDK-kal kölcsönhatásba lépő proteint/kinázt gátló fehérje családot (CIP/KIP - CDK INTERACTING PROTEIN/KINASE INHIBITOR PROTEIN), amely a G1 és G1/S fázisátmenetre specifikus CDK-ciklin komplexeket gátolja (Risal, Adhikari és Liu, 2016).

\begin{tabular}{|c|c|c|c|c|}
\hline Faj & Név & Eredeti név & Méret (aminosav) & Funkció \\
\hline Saccharomyces cerevisiae & CDK1 & CDC28 & 298 & Minden sejtciklus fázisban \\
\hline Schizosaccharomyces pombe & CDK1 & CDC2 & 297 & Minden sejtciklus fázisban \\
\hline Drosophila melanogaster & CDK1 & CDC2 & 297 & G2/M \\
\hline & CDK2 & CDC2C & 314 & G1/S, S (G2/M-ben lehetséges) \\
\hline & CDK4 & CDK4/6 & 317 & G1 \\
\hline Xenopus laevis & CDK1 & CDC2 & 301 & G2, M \\
\hline & CDK2 & CDK2 & 297 & S (G2/M-ben lehetséges) \\
\hline Homo sapiens & CDK1 & CDC2 & 297 & G2, M \\
\hline & CDK2 & CDK2 & 298 & G1, S (G2/M-ben lehetséges) \\
\hline Arabidopsis thaliana & CDK4 & CDK4 & 301 & G1 \\
\hline & CDK6 & CDK6 & 326 & G1 \\
\hline & & CDKA;1 & 294 & G1/S, G2/M \\
\hline & & CDKB1;1 & 309 & S2/M \\
\hline & & CDKB1;2 & 311 & GD/M \\
\hline
\end{tabular}

1. táblázat. A sejtciklusban közvetlenül szabályozó szerepet játszó eukarióta CDK-k listája a modellorganizmusok alapján

A sejtciklus szabályozását a ciklin függő protein kinázok (CDK) a ciklinekkel komplexben végzik. A különböző organizmusokban eltérő számú és funkciójú CDK-k találhatóak, amelyek sejtciklus-specifikusan, különböző fázisokban (G1, S, G2 és M fázisok) működhetnek. A B típusú növényspecifikus CDK-knak nincs állati megfelelője, így a „Név” oszlop sorait üresen hagytuk (Morgan, 2007; Adachi, Uchimiya és Umeda, 2006; https://www.uniprot.org).

A CDK-k irányítják a sejtciklus fő lépéseit, de aktivitásukat komplex folyamatok szabályozzák.

A CDK-k maximális aktivációjához a ciklin kötődés mellett az aktív centrum közelében lokalizálódó treonin aminosav (röviden T) foszforilációja is szükséges (ami a CDK1 esetében a 161-es, míg a CDK2-nél a 160-as pozícióban található), amelyet a CDK-AKTIVÁLÓ KINÁZ (CAK) hajt végre. Ez a foszforiláció jelentősen, akár háromszázszorosára is megnövelheti a kináz affinitását a szubsztrát fehérje irányába. Ezzel szemben a 14-es pozíciójú treonin (T14) és a 15ös tirozin (Y15) foszforilációja gátolja a CDK2 és CDK1 enzimek aktivitását. A WEE1 (név eredete: a skót wee szóból származik, jelentése kicsi) és MYT1 (MEMBRANE ASSOCIATED TYROSINE / THREONINE 1) kinázok felelősek a T14/Y15 helyek foszforilációjáért. Az inhibitor foszfát csoportok eltávolítását a CDC25 (CELL DIVISION CYCLE 25) foszfatáz végzi (Vigo és mtsai., 1999; Perry és Kornbluth, 2007). A CDK-k gátlását okozhatják a CDK inhibitorok (CKI) is, amelyeken belül két csoportot különböztetünk meg: a CDK4 inhibitorokat (INHIBITOR OF CDK4 - INK4), melyek a CDK4 mellett a CDK6 inhibitorai is, és a CDK-kal kölcsönhatásba lépő proteint/kinázt gátló fehérje családot (CIP/KIP - CDK INTERACTING 
PROTEIN/KINASE INHIBITOR PROTEIN), amely a G1 és G1/S fázisátmenetre specifikus CDK-ciklin komplexeket gátolja (Risal, Adhikari és Liu, 2016).

\subsubsection{A növényi sejtciklus szabályozása}

A növényekben is megtalálhatóak a CDK-rokon fehérjék (1. táblázat), amelyek a sejtciklus különböző fázisaira specifikus ciklinekkel formálnak komplexet. A CDK-k és ciklinek száma növényfajonként változhat. Az Arabidopsis thaliana genom 29 különböző ciklin-függő protein kinázt $(C D K A-F)$ tartalmaz - ezek 8 alcsoportba sorolhatók - és több mint 49 ciklint kódol, míg például az egyszikü rizsben 25 CDK-t és 49 ciklint azonosítottak (Wang és mtsai., 2004; La és mtsai., 2006; Guo és mtsai., 2007; Dudits, 2007). A sejtciklus szabályozásában közvetlenül csak az A- és B-típusú CDK-k vesznek részt (1. táblázat). Az A-típusú CDK (CDKA;1), strukturálisan és funkcionálisan a CDC2/CDC28, azaz a CDK1 növényi megfelelöje, amely képes a $c d c 2$ knockout élesztőben helyettesíteni a CDC2 funkcióját (Hirt és mtsai., 1991; Ferreira és mtsai., 1991). A B-típusú növényspecifikus CDK-k kevésbé hasonlítanak az élesztő CDC2/CDC28 kinázhoz (pl. a konzervált PSTAIRE ciklin-kötő motívum változataival rendelkeznek - 1 . táblázat), és nem képesek helyettesíteni az élesztő CDC2/CDC28 mutánsokat (Hirayama és mtsai., 1991; Hirt és mtsai., 1991). A növényi A-típusú CDK konstitutívan jelen van a sejtciklus minden fázisában, de a kináz aktivitása fázis-specifikusan változik, és a G1-S és a G2-M fázisátmenetekben éri el a maximális aktivitását (Magyar és mtsai., 1993; Magyar és mtsai., 1997). A sejtciklusba lépést, a G1/S fázisátmenetet a CDKA;1 a D-típusú ciklinekkel (CYCD) együtt szabályozza. A G2 fázisban a CIKLIN A-val (CYCA), míg az M fázisban a CIKLIN Bvel (CYCB) alakít aktív komplexet. A növényi ciklinek az állati ciklinekhez hasonlóan vannak elnevezve, köszönhetően a nagymértékü homológiának (Nieuwland és mtsai., 2007).

A növényi interfázisú CDK-k a B-típusú CDK-k, amelyek az állati interfázisú CDK-kal szemben döntően a G2 és $M$ fázisok koordinálásában vesznek részt, komplexben a ciklin A és $B$ fehérjékkel (Magyar Z, 1997; Dudits, 2007). Ezek a B-típusú CDK-k a CDKA;1-gyel szemben sejtciklus-specifikusan fejeződnek ki, elsősorban a G2 és M fázisokban. A B-típusú CDK-kat két alcsaládra osztjuk (CDKB1 és CDKB2, két-két taggal mindegyikben), amelyeket szerkezetileg az eltérő ciklin-kötő motívumaik alapján különítünk el (Arabidopsisban: PPTALRE a CDKB1ben és PS/PTTLRE a CDKB2-ben, a betük a konzervált aminosavakat jelölik). A CDKB1 szerepet játszik az M fázis szabályozásában, és a levél zárósejtek fejlődésében és osztódásában (Boudolf és mtsai., 2004a; Xie és mtsai., 2010). A gyökér merisztémában a CDKB1;1 a CYCD6;1-gyel komplexben szabályozza az iniciálisok aszimmetrikus osztódását (Cruz-Ramirez és mtsai., 2012). A funkcionális vizsgálatok arra utalnak, hogy a CDKB2-k fontos szerepet játszanak a hajtás merisztéma szerveződésében és müködésében (Andersen és mtsai., 2008). Mindezek alapján a B-típusú CDK-k fontos szerepet játszanak a merisztematikus sejtek osztódásában és fenntartásában. Fontos megemlíteni, hogy az E2F transzkripciós faktorok 
(amelyek az osztódásba lépést is aktiválják, lásd később) szabályozzák a $C D K B$-k expresszióját, mégpedig a promóter régiójukban megtalálható cisz-ható E2F-kötő elemeken keresztül, ezáltal összekapcsolva a G1/S és a G2/M fázisátmeneteket (Boudolf és mtsai., 2004b). Korábban feltételezték, hogy a CDKA;1 a többi CDK1-hez hasonlóan a növényi sejtosztódás esszenciális faktora, és hiányában nem jöhet létre életképes növény. Azonban Nowacknak és munkatársainak sikerült cdka;1 mutáns növényeket előállítani (Nowack és mtsai., 2012). A cdka;1 mutáns embrióban az összsejtszám ugyan drámaian lecsökkent (a kontrollhoz képest csak 10\%-nyi keletkezett), de a növényi fejlődés rugalmasságának köszönhetően még ilyen drasztikusan kevés sejttel is életképes embrió jött létre. Ez egyben azt is jelenti, hogy a B-típusú CDK-k jelenlétében az irányított embrionális osztódások sikeresen megtörténtek, és bizonyos mértékig képesek voltak helyettesíteni a CDKA;1 funkcióját az osztódások szabályozásában is. Ezzel összhangban a $c d k a ; 1 ~ c d k b 1 ; 1 ~ c d k b 1 ; 2$ tripla mutánsok elóállítása már nem volt lehetséges (Nowack és mtsai., 2012)

Az állatokhoz hasonlóan a növényekben is szerepet játszanak más faktorok a CDK-k szabályozásában és a sejtosztódás koordinálásában. A maximális CDK-ciklin komplex aktivitásához, akárcsak az állatokban, a növényekben sem elegendő a komplexek megnövekedett mennyisége. A CDK-k már korábban leírt PSTAIRE aminosav motívuma szolgál a ciklinek megkötésére. A PSTAIRE motívum T-loop/aktivációs T-hurkának foszforilációja biztosítja a CDK-k aktivációját, amelyet itt is a CDK aktiváló kinázok (CAK) hajtanak végre. A növényekben a CAK-okat két csoportba soroljuk, ezek a D- és F-típusú CDK-k (Umeda és mtsai., 1998; Takatsuka, Ohno és Umeda, 2009). Habár a növényi CDKA1 is tartalmazza azokat a konzervált motívumokat, amelyeket az állati CDK1-ek (T14 és Y15), érdekes módon a növényekben nincs CDC25 foszfatáz, és bár WEE1 kináz homológ ugyan van, de szerepe a DNShibajavítási folyamatokra korlátozódik (Boudolf, Inzé és De Veylder, 2006; De Schutter és mtsai., 2007). A növényi sejtciklus fö negatív regulátorai a CIKLIN-FÜGGÖ PROTEIN KINÁZ INHIBITOROK (CKI), amelyeknek két családja ismert: a KIP-ROKON FEHÉRJÉK (KRP) és a SIAMESE és rokon fehérjéik (SIM/SMR), amelyek az S és M fázisú CDK-ciklin komplexeket képesek inaktiválni (1. ábra B; Torres Acosta, Fowke és Wang, 2011; Churchman és mtsai., 2006). Ez a mechanizmus felelős az M fázisba lépés és a citokinézis gátlásáért, mely gyakran endoreduplikációhoz vezet, azaz a sejtek ploiditásának és ezáltal méretének megnövekedéséhez (Kumar és Larkin, 2017). 


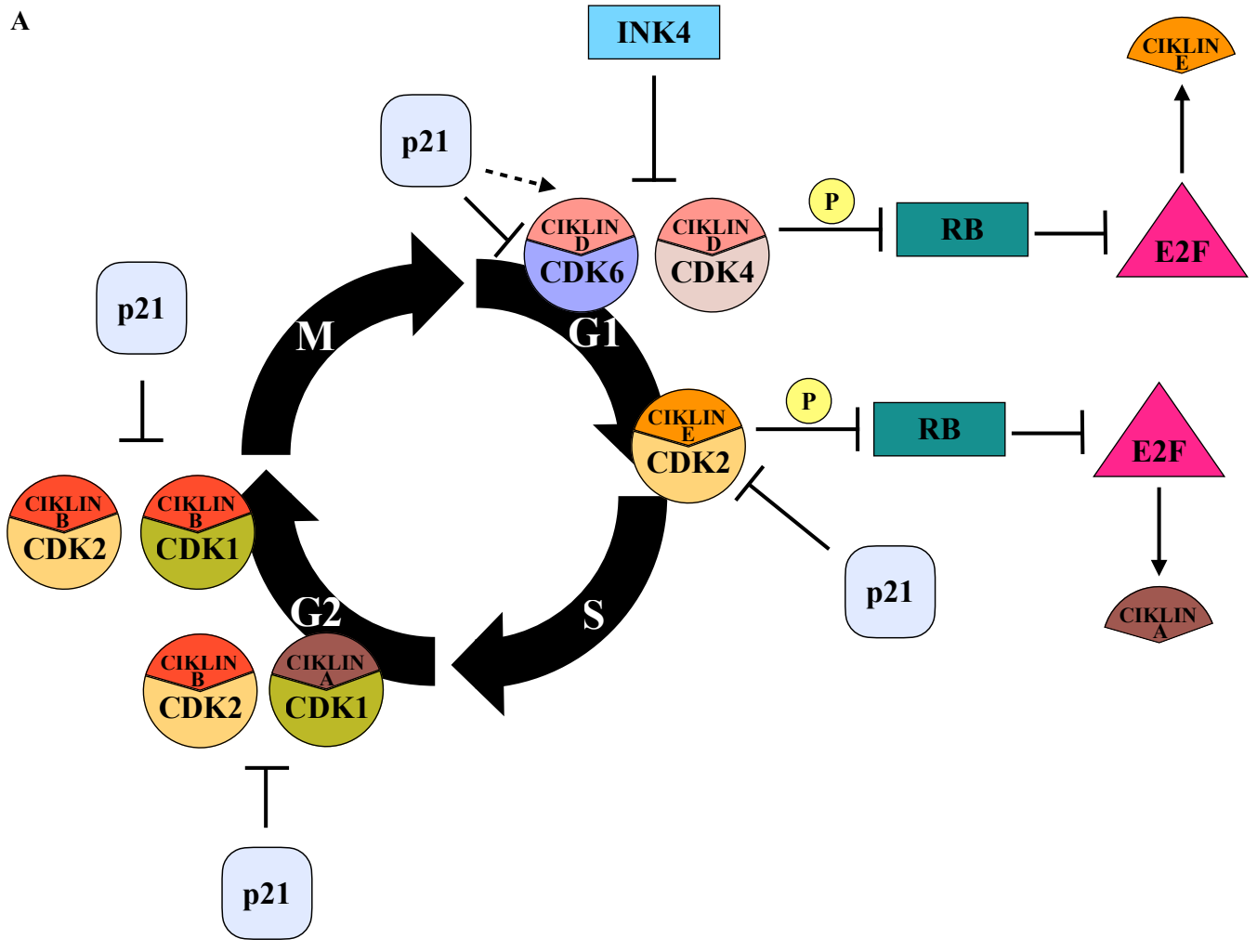

B

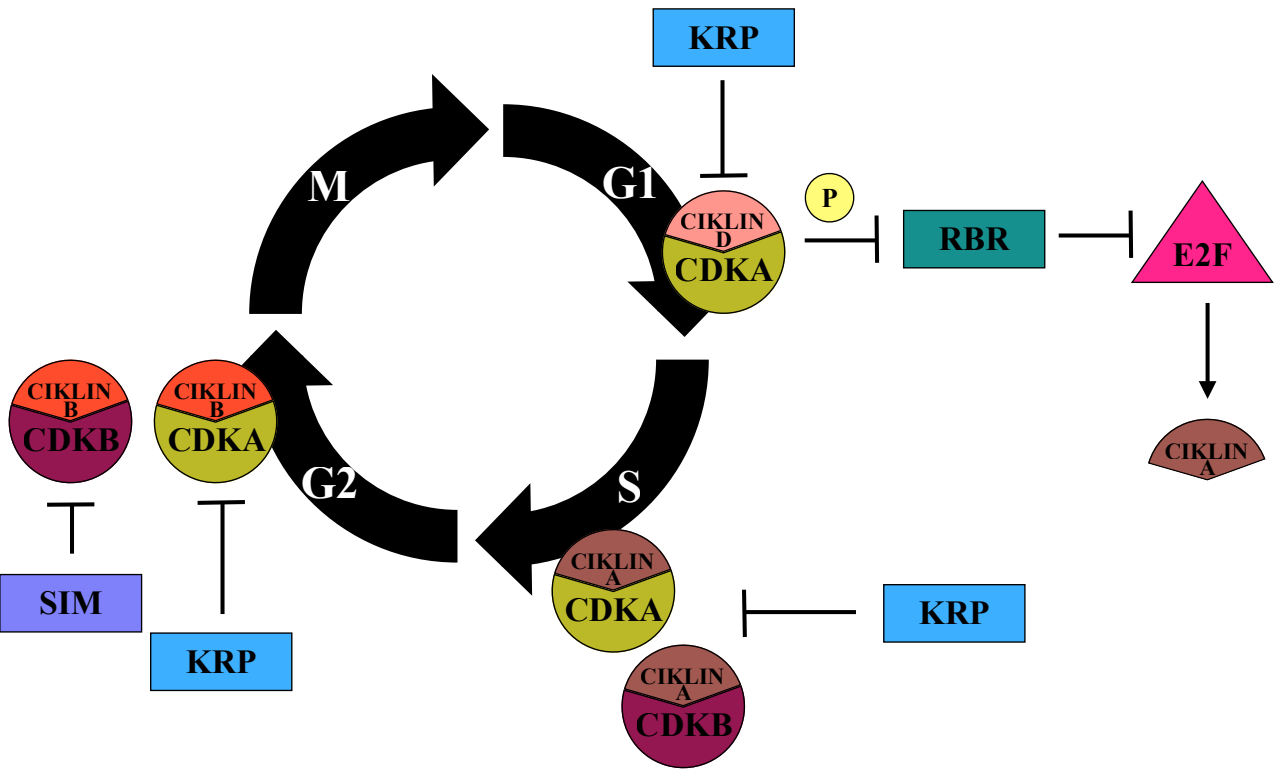

1. ábra. Az emlős és a növényi sejtciklus szabályozó molekulái

Az állati és növényi sejtciklus négy jól meghatározott fázisát (G1 = Gap-1, S = DNS-szintézis, G2 = Gap-2, M = mitózis) periodikusan aktiválódó ciklin-függő protein kinázok (CDK) szabályozzák, amelyek irányításában a különféle ciklin-szabályozó alegységek (A, B, D, E), és CDK-gátló fehérjék (INK4, p21, KRP, SIM) játszanak szerepet. Mind az A) emlős, mind a B) növényi sejtciklus során a késői G1 vagy G1/S fázisátmenethez a negatív regulátor - retinoblasztóma $(\mathrm{RB})$ vagy retinoblasztóma-rokon (RBR) fehérjék - CDK által közvetített foszforilációja szükséges (P), ami az E2F transzkripciós faktorok felszabadulását eredményezi. Az E2F-ek aktiválják a ciklin gének expresszióját, amely szükséges a sejtciklusba lépéshez. Az állati és növényi sejtciklus során a szabályozó molekulák sok esetben homológiát mutatnak egymással, ezek jelölése az A és B ábrán azonos színnel történt. A szabályozás hasonlóságai ellenére az állati és növényi sejtek különböző CDK-ciklin komplexekkel rendelkeznek. A nyilak az aktivációs lépéseket, a tompa végü nyilak a gátlási folyamatokat, P a foszforilációt jelzi (Fehér és Magyar, 2015). 


\subsubsection{Az evolúciósan konzerválódott retinoblasztóma-E2F transzkripcionális szabályozás molekuláris mechanizmusa}

$\mathrm{Az}$ eukarióta szervezetek az RB-E2F szabályozást már az evolúció korai stádiumában kifejlesztették, habár a szabályozás egyes organizmusokból, mint például a gombák Dikarya alországából teljesen hiányzik (ide tartoznak a $S$. pombae és $S$. cerevisiae élesztő fajok is, Függelék I. ábra). Az élesztősejtekben strukturálisan nincsen E2F és RB fehérje, azonban jelen van bennük egy funkcionálisan hasonló szabályozási mechanizmus. Ebben a fő transzkripciós represszor a WHISKEY 5 (WHI5), amely képes az SBF (SCB-BINDING FACTOR) és a MBF (MCB-BINDING FACTOR) transzkripciós faktorok gátlására egyaránt. Az SBF és MBF szabályozzák a G1/S fázisátmenetet, koaktivációs komplexet alkotva két szekvenciaspecifikus DNS-kötő proteinnel; ezek az SWI6P (CELL-CYCLE BOX FACTOR SUBUNIT SWI6), illetve az SBF esetében a SWI4P (CELL-CYCLE BOX FACTOR SUBUNIT SWI4), az MBF esetében pedig a MBP1P (Breeden, 2003; Costanzo és mtsai., 2004; de Bruin és mtsai., 2004; Bähler, 2005; Pramila és mtsai., 2006). Ezek a komplexek kötődnek az SCB (SWI CELL CYCLE BOX) és MCB (MLUL CELL CYCLE BOX) upstream szabályozó elemekhez, ezzel aktiválva gének százainak expresszióját (Iyer és mtsai., 2001; Simon és mtsai., 2001). Az egysejtű zöld algában (Chlamydomonas reinhardtii) egy-egy kópia kódolja az E2F-RB transzkripcionális szabályozásban résztvevő $R B$ (MAT3), E2F (E2F1) és DP (DP1-DIMERIZATION PARTNER1) homológ géneket (Bisova, Krylov és Umen, 2005). Az állati E2F-RB modell szerint, amelyet a 2. ábra mutat be, a sejtosztódás szabályozásában részt vevő gének kifejeződését az E2F aktiválja, míg az RB fehérje az E2F-hez kapcsolódva gátolja. Az RB sejtosztódást gátló funkcióját az RBkinázok, specifikus ciklin-függő protein kinázok (CDK-k) semlegesítik (Magyar, 2008). Ez az egyszerü, úgynevezett klasszikus E2F-RB modell az utóbbi évek kutatásai alapján lényegesen komplexebbé vált. Az ecetmuslicában (Drosophila melanogaster) is megtalálható az E2F/RB szabályozás, de még kevésbé komplex formában, amely megkönnyítette a „szereplők” funkcionális jellemzését. Az ecetmuslica két RB homológgal (retinoblasztóma faktor 1 és 2; RBF1 és RBF2), és egyetlen DP-vel (dDP) rendelkezik, amely a légy két E2F faktorával (dE2F1és dE2F2) formál heterodimert (a „d” a rövidítések elején a Drosophilára utal; Dimova és mtsai., 2005; Stevaux és Dyson, 2002; van den Heuvel és Dyson, 2008). A dE2F1 a sejtciklus aktivátora, a dE2F2 pedig a represszora. A dE2F1 nélkül redukálódik az $\mathrm{S}$ fázisba lépő sejtek száma, és az E2F célgének expressziója, aminek köszönhetően kisebb méretű lárva fejlődik. Amikor a $d E 2 F 1$ mellett a $d E 2 F 2$-t is inaktiválták, a lárva előzőekben leírt növekedési fenotípusa helyreállt. Ez arra engedett következtetni, hogy a két dE2F antagonisztikus viszonyban áll egymással, és a de2f1 mutánsban a represszor dE2F2 gátló hatása érvényesül. A két dE2F hiányában ugyanakkor nem állt le a sejtosztódás, ami alapján a dE2F-ek funkciója nem esszenciális komponense a sejtosztódás szabályozásának (Frolov és mtsai., 2001). A későbbi vizsgálatok kimutatták, hogy a dE2F2 része egy többkomponensủ fehérje komplexnek, amely 
osztódó sejtekben differenciálódási géneket represszálhat (Lee és mtsai.; 2010). A komplexet a benne résztvevő komponensekről dDREAM-nek nevezték el (DP-RBF-E2F-And-MYB (VMYB AVIAN MYELOBLASTOSIS VIRAL ONCOGENE HOMOLOG)). A fonalféreg (Caenorhabditis elegans) szintén rendelkezik E2F- és DP-rokon fehérjékkel. Ezek fö szerepe viszont nem a sejtosztódás koordinálása, inkább a differenciálódási és fejlődési folyamatok szabályozása és az embrionális fejlődés irányítása (szimmetria kialakítása), ezen kívül a RAS/MAPK (MITOGEN-ACTIVATED PROTEIN KINASE) jelátviteli út részét képzik (Page és mtsai., 2001). Ezen felül a Drosophila DREAM komplexhez hasonló összetételü E2F- és RBtartalmú multikomponensủ fehérje komplexet izoláltak a fonalféregből is (DP-RB, MuvB MULTI-VULVAL CLASS B - röviden DRM komplex, Sadasivam és DeCaprio, 2013). Az emlösállatokban és növényekben az E2F-ek és az RB-k egyaránt egy több tagból álló család részei, ahol a funkciók részben átfednek, részben pedig egyediek. Ezekre részletesen az E2F-ek és RB-k szerkezeti leírásánál fogok kitérni.
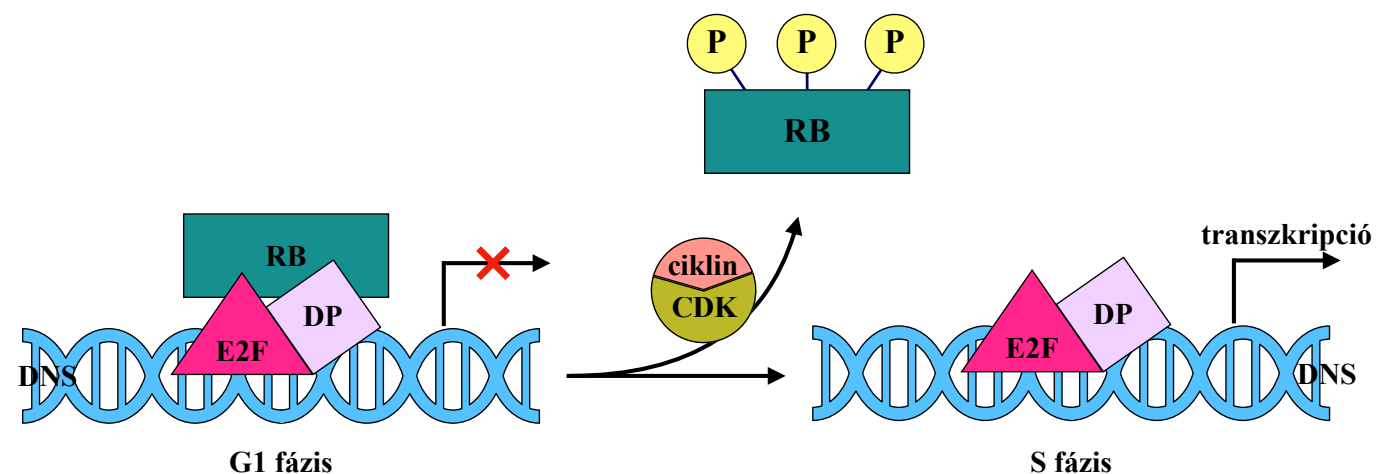

2. ábra. Az E2F-RB szabályozási mechanizmus az osztódásba lépés során, a G1/S fázisátmenetben

A korai állati modellorganizmusokban és sejtkultúrákban végzett kísérletek eredményein alapuló modell. A kezdeti G1 fázisban az alulfoszforilált RB az E2F-DP heterodimerhez kötődik és így megakadályozza a sejtciklus gének aktiválódását. A késői $\mathrm{G1}$, majd az $\mathrm{S}$ fázis során mitogének hatására (az ábrán nincs feltüntetve) CDK-ciklin komplexek aktiválódnak, elsőként a CDK-CIKLIN D, majd később a CDK-CIKLIN A. Hatásukra az RB felülfoszforilálódik, amely szabadon engedi az E2F-DP heterodimert. Az aktív E2F-DP indukálja a sejtciklus célgének expresszióját, amelyek fontos szerepet játszanak az osztódásba lépésben, a DNS szintézisében, és a kromatin összeszerelödésben is (Shen, 2002).

\subsubsection{Az E2F transzkripciós faktorok felépítése és a sejtciklus során betöltött szerepe magasabb rendü organizmusokban}

Az emlősökben több tagból áll az E2F transzkripciós faktor család, és jellemzésüket lényegesen megnehezíti, hogy szerepeik egymással átfednek. Általánoságban elmondható, hogy az E2F család tagjai a sejtciklus szabályozásában vesznek részt; lehetnek transzkripcionális aktivátorok (E2F1, E2F2, E2F3a) és represszorok (E2F3b, E2F4, E2F5, E2F6, E2F7, E2F8). Az E2F-ek heterodimerként funkcionálnak; egy E2F egy DP fehérjével dimerizál (kivéve E2F7 és E2F8). A legtöbb E2F szerkezeti felépítése hasonló, és az N-terminálistól a C-terminális felé haladva sorrendben a következő konzervált régiókból áll: DNS-kötő domén, dimerizációs domén, „marked-box”, RB-kötő domén, transzaktivációs domén (ez utóbbi nincs az E2F6 és E2F8 faktorokban, Johnson és Schneider-Broussard, 1998). Az emlösállatokban kilenc különbözö 
E2F-et, két dimerizációs partnert (DP1 és DP2), valamint három retinoblasztóma-rokon úgynevezett zsebfehérjét (pocket proteins, RB, p107, p130) különböztetünk meg. Az E2F1, E2F2 és az E2F3a erős transzkripciós aktivátorok, amelyek nyugvó sejtekben egyáltalán nem, vagy csak alacsony szinten vannak jelen, ezzel szemben magas szinten expresszálódnak a G1 fázisban, serkentve ezzel a G1/S fázisátmenetet (Dyson, 1998). A represszor alcsalád tagjai közül az E2F3b, E2F4 és E2F5 a sejtciklus során végig jelen vannak, a retinoblasztóma-rokon fehérjékkel komplexet alkotva, korepresszorként célgének promótereihez kapcsolódnak, így gátolva a transzkripciót (Attwooll, Lazzerini Denchi és Helin, 2004). Az E2F6 nem képes kötődni a retinoblasztóma-rokon fehérjékhez, azonban egy több tagból álló komplex részeként (amely tartalmazza a polycomb fehérjecsalád egyes tagjait is) fejti ki gátló hatását (Ogawa és mtsai., 2002; Giangrande és mtsai., 2004). Az E2F7 és E2F8 transzkripciós faktorok megfelelöit elöször növényekben írták le (DP-E2F-LIKE, röviden DEL1-3, Kosugi és Ohashi, 2002; de Bruin és mtsai., 2003; Logan és mtsai., 2005). Ez utóbbi E2F-ek csak távoli rokonságban állnak a többi E2F-fel (lásd később), és akárcsak az E2F6, nem képesek kötődni a retinoblasztóma-rokon fehérjékhez (Dimova és Dyson, 2005; Cobrinik, 2005; Li és mtsai., 2008).

Az Arabidopsis modellnövényben 6 funkcionális E2F gént különíthetünk el, amelyek in vitro képesek ugyanazokhoz a DNS motívumokhoz kötődni, azonban szerkezetükben és funkciójukban eltérnek egymástól. Konzervált régióik összetétele alapján 2 alcsaládra oszthatjuk őket (3. ábra). Az egyik alcsaládba azok az E2F-ek tartoznak (DEL1/E2FE, DEL2/E2FD, DEL3/E2FF), amelyek a többi E2F-hez csak a DNS-kötö régiójukban hasonlítanak, ebböl azonban kettő található bennük tandem elrendeződésben (emlős rokonaik az E2F7 és E2F8). Ezek a transzkripciós faktorok nem dimerizálnak a DP fehérjékkel, RBR-függetlenek, és transzaktiválásra sem képesek. A DNS-kötő doménjeik révén azonban ugyanazokhoz a célgénekhez kötődhetnek, mint a többi E2F, és így mind a represzor mind pedig az aktivátor E2F-k müködését befolyásolhatják (Kosugi és Ohashi, 2002).

A másik alcsaládban három E2F-rokon fehérje található, ide tartozik az E2FA, E2FB és E2FC, amelyek az E2F transzkripciós faktorokra jellemző összes konzervált domént tartalmazzák. A DNS-kötő domén egy úgynevezett winged hélix-turn-hélix motívum, ahol a „szárnyakat” $\beta$ lemezek alkotják. A hélix-turn-hélix szerkezet a DNS-en a specifikus szekvencia felismerést teszi lehetővé, míg a $\beta$-lemezek a DNS és a transzkripciós faktor közti kapcsolatot stabilizálják (Gajiwala és Burley, 2000). Azonban ez nem elégséges feltétele a DNS kötésnek. Ehhez szükség van az E2F-eknek dimerizálni a velük rokon fehérjékkel, a DPA és DPB dimerizációs partnerekkel (De Veylder, Beeckman és Inzé, 2007), amely egy leucin heptád ismétlődést tartalmazó dimerizációs doménen keresztül valósul meg (Vidal és mtsai.,1996). Így az E2F-DP heterodimer együttesen képes kötődni az E2F-specifikus promóter régiókhoz, amelyek befolyásolják a környező gének átíródását (cisz-elemek). A dimerizációs domén mellett a Cterminális irányban foglal helyet az úgynevezett marked-box domén, amelynek szerepe van a 
heterodimer kialakításában és a DNS geometriai szerkezetének módosításában is. A módosítás hatására az egymástól távol bekötődött transzkripciós faktorok közelebb kerülnek egymáshoz, és transzkripciós komplexeket hoznak létre (van der Vliet és Verrijzer, 1993; Vidal és mtsai., 1996, Cress és Nevins, 1996; Black és mtsai., 2005). A fehérje C-terminálisának legutolsó konzervált doménja a transzaktivációs domén, amelyen belül található az RBR-kötő régió is (3. ábra; Mariconti és mtsai., 2002; Magyar, 2008).

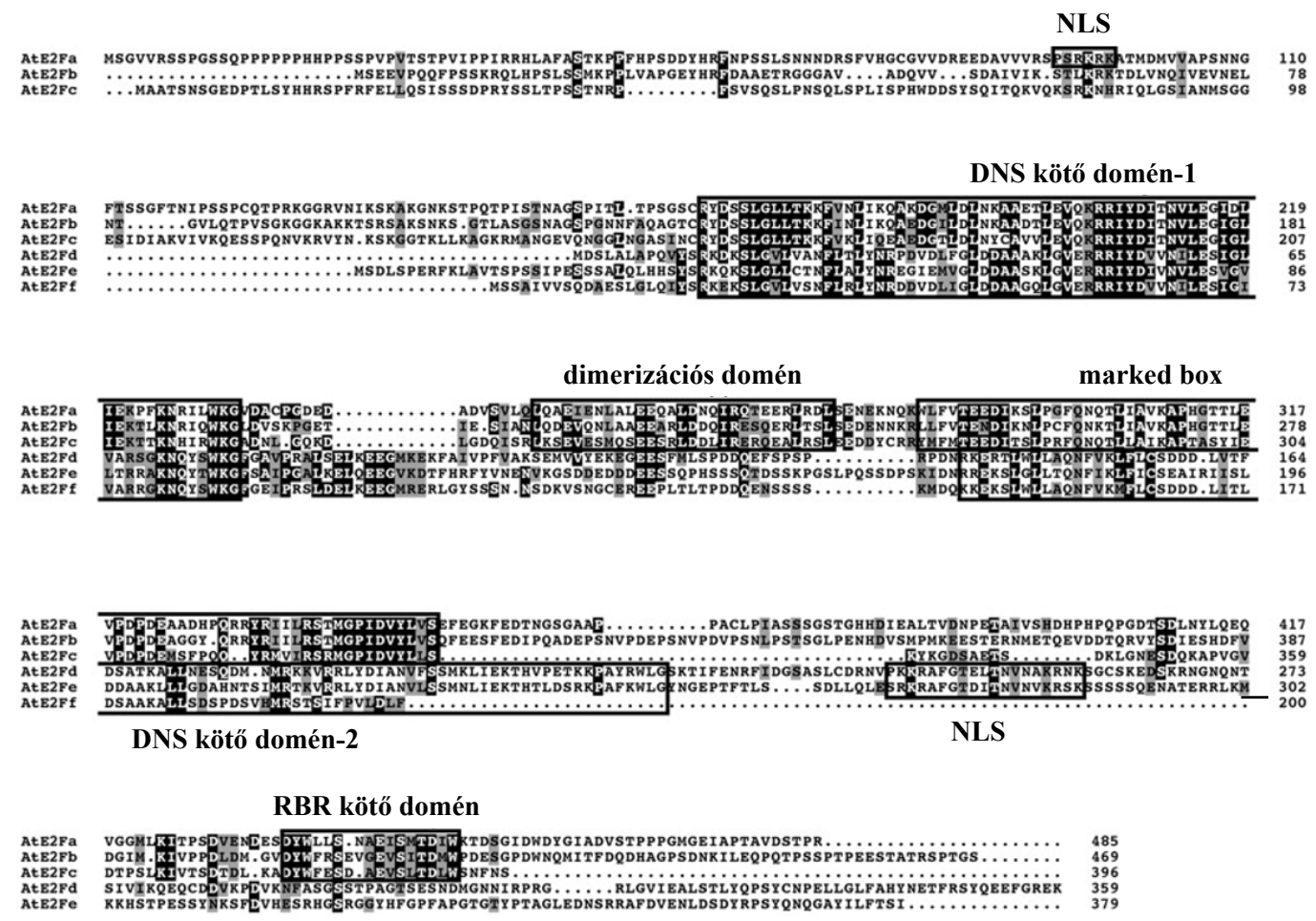

3. ábra. Az Arabidopsis E2F transzkripciós faktorok aminosav-sorrendje és konzervált doménjei

Fekete háttéren fehér betük jelzik az egyező aminosavakat, míg szürke háttéren fekete betük jelölik a hasonló aminosavakat. A konzervált régiókat a fekete keretek mutatják. A konzervált régiók: NLS = nukleáris lokalizációs szignál; DNS-kötő domén-1, minden E2F-ben megtalálható; dimerizációs domén; marked box; DNS-kötő domén-2, csak az E2FD, E2FE és E2FF-re jellemző; RBR-kötő domén (Mariconti és mtsai., 2002).

\subsubsection{Az RB tumorszupresszor szerkezete és funkciója}

A retinoblasztóma $(R B)$ gént tumorszupresszorként azonosították, amelynek a csíravonalban történő mutációja rosszindulatú daganatot okoz a retinában. Az RB további jellemzése kiderítette, hogy számos más folyamatban is szabályozó szerepet játszik, nemcsak a sejtciklusban, de az endoreduplikációban, a transzkripciós szabályozásban, kromatin átalakításban, fehérjék lebontásában, kromoszóma stabilitásban, DNS rekombinációs folyamatokban, őssejt állapot megőrzésében, sejtnövekedésben, sejthalálban, és a differenciálódásban is (Desvoyes és mtsai., 2014).

Az RB az úgynevezett „zsebfehérjék” (pocket proteins) családjába tartozik, amelyből emberben összesen hármat izoláltak (RB, p107 és p130). A daganatos megbetegedések egy jelentős százalékáért az RB mutációja, illetve az RB-útvonal egyéb hibái tehetők felelössé (Vélez-Cruz és G. Johnson, 2017). Az RB család tagjai különböző E2F-ekkel a sejtciklus eltérő szakaszaiban 
lépnek kölcsönhatásba. Az RB elsősorban az aktivátor E2F1, E2F2 és E2F3 faktorokkal alkot komplexet, és a G1/S fázisátmenetnél aktív. Ezzel szemben a p130 elsősorban a represszor E2F4gyel és E2F5-tel lép kölcsönhatásba, és a G0-ban - a sejtciklus nyugalmi fázisában - müködik aktívan (Lee és mtsai., 2013). Az RB fehérjék kötődése az E2F fehérjékhez blokkolja az E2F célgének aktiválódását, és serkenti a transzkripciós korepresszorok kötődését. Az RB az E2F faktorok mellett egyidejüleg kromatin szerkezetet befolyásoló enzimekkel is kölcsönhat, mint a HDAC1 (HISZTON-DEACETILÁZ-1), amely csökkenti a DNS hozzáférhetőségét, meggátolva azon gének transzkripcióját, amelyek a G1/S fázisátmenetet serkentik (Ferreira és mtsai., 1998). Az RB nemcsak az E2F TF-ral, hanem számos más fehérjével, további transzkripciós faktorokkal is képes komplexbe lépni; mint a SWI/SNF (SWITCH / SUCROSE NON-FERMENTABLE), amely egy ATP-függő kromatin remodelling komplex, a represszor PRC2-vel (POLYCOMB REPRESSIVE COMPLEX 2), amellyel együtt a gaméta fejlődést szabályozzák, vagy a MET1gyel (DNA METHYLTRANSFERASE 1), amely biztosítja a magkezdemény centrális sejtjében a heterokromatin állapot fenntartását (Zhang és mtsai., 2000; Johnston és mtsai., 2008). Egyes kis DNS tumor vírusok onkoproteinjei, mint például az adenovirus E1A, SV40 nagy T antigén vagy humán papillomavirus E7 direkt módon kötődhetnek az RB-hez, inaktiválhatják, és ezzel sejtburjánzást, rákos daganatok kialakulását indukálhatják (Dyson, 1998; Classon és Dyson, 2001).

Az RB evolúciósan konzerválódott fehérje, rokonai mind az állatokban, mind a növényekben megtalálhatók, különböző számban (Függelék I. ábra, Függelék III. ábra). Az Arabidopsisban, mint a kétsziküekben általánosan, egy RB-rokon fehérje található, ez az RBR vagy RBR1. Az egyszikű Brachypodium distachyon (szálkaperje) esetében viszont kettő, míg a Sorghum bicolor (tarka cirok), a kukorica és a rizs esetében három RBR-t találtak (Desvoyes és mtsai., 2014; Lendvai és mtsai., 2007).

Az RB fehérjék 3 szerkezeti egységre bonthatók (4. ábra, Függelék III. ábra). Az amino terminális domén (RBN), amely szerkezetileg nagymértékben hasonlít az őt követő doménre, a középső úgynevezett pocket (zseb) régióra, amelyről a fehérjecsalád a nevét kapta. Az A és B zsebből felépülő centrális domén teszi alkalmassá az RB-t az E2F-kötésre, de ide kötődnek más fehérjék is (pl. kromatin remodelling enzimek, hiszton modifikáló enzimek, ciklinek és a virális onkoproteinek is). Minderre a zseb doménen lokalizálódó LXCXE-kötő motívum konzervált ciklin redője (ciklinekben is megtalálható motívum) teszi képessé (Lee, Russo és Pavletich, 1998; Dahiya és mtsai., 2000), ami független az RB-ben található E2F-kötő helytől. A harmadik konzervált alegység a karboxi terminális domén (RBC), ami az E2F-ek marked boxának és az E2F dimerizációs partnerének megkötésért, illetve a kináz és foszfatáz dokkolásért is felelős (Rubin és mtsai., 2005; Hirschi és mtsai., 2010). A domének közötti részeken helyezkednek el a kapcsoló szekvenciák, amelyek az RB legkevésbé konzervált szakaszai, azonban ezek tartalmazzák a CDK-függő foszforilációs helyeket, amelyek meghatározó szerepet játszanak az 
RB működésében, szerkezetének átrendezésében és ezúton történő inaktiválásában. (4. ábra; Adams és mtsai.,1999; Dick és Rubin, 2013).

A

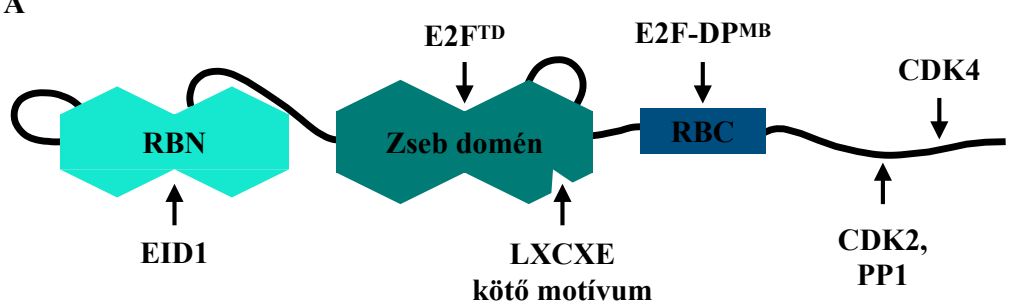

B

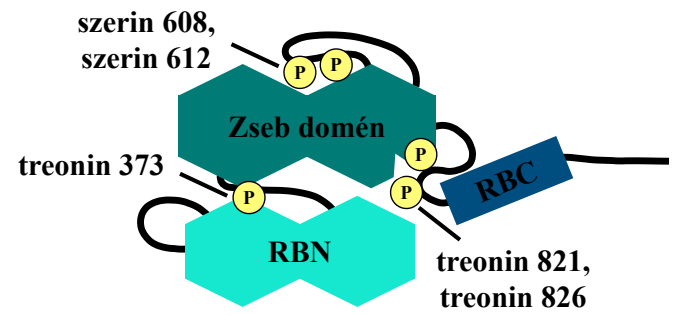

4. ábra. Az emlős RB egy többfunkciós multidomén fehérje

A) Az RB struktúrájának és ismert fehérjekötő helyeinek sematikus ábrája. B) Az RB foszforilált, inaktivált konformációja. A 373-as treonin foszforilációja az RBN és a zseb domén szoros összekapcsolódásához vezet, míg a 608-as és 612-es számú szerin és a 821 és 826-os számú treonin foszforilálódása a zseb domén hurkát és az RBC domént kapcsolja a zseb doménhez. Ezek a konformáció változások vezetnek a specifikus RB-fehérje interakciók gátlásához. $\mathrm{CDK}=$ CIKLIN-FÜGGÖ PROTEIN KINÁZ; DPMB = DIMERIZÁCIÓS PARTNER és marked box; $\mathrm{E} 2 \mathrm{~F}^{\mathrm{TD}}=\mathrm{E} 2 \mathrm{~F}$ transzaktivációs domén; EID1 = E1A-SZERÜ DIFFERENCIÁLÓDÁS INHIBITOR 1; PP1 = PROTEIN FOSZFATÁZ 1 (Dick és Rubin, 2013)

\subsubsection{A növényi RBR/E2F szabályozási mechanizmus}

Az Arabidopsis thalianaban a gének mintegy 25\%-a tartalmaz E2F-kötő elemet a promóter régióban, amely lényegesen gyakoribb, mint amit az emlős gének esetében figyeltek meg $(\sim 2 \%$, Vandepoele és mtsai., 2005). A különböző E2F-ek pontos szabályozási szerepe még nem teljesen ismert, sem az, hogy funkcióik mennyire egyediek vagy menyire átfedők. A különbözö növényi szervekben az expressziós analízisük eltér egymástól (Függelék II. ábra), ami alapján a különböző E2F-ek eltérő funkciókat is betölthetnek a fejlődő Arabidopsis növényekben. Az E2FA, E2FB és E2FC fehérjék megjelenésük alapján a gyökér merisztémában is specifikus tulajdonságokkal rendelkeznek (5. ábra; Magyar és mtsai., 2012, és nem közölt eredményeink alapján). Az E2FA elsősorban a gyökér merisztéma központjában, elsősorban az osztódó régió sejtjeiben jelenik meg a legerősebben, míg az E2FB esetében épp ellenkezőleg, a merisztéma távolabbi zónájában, a megnyúlásnak induló poszt-mitotikus sejtekben a legerösebb a jel. A represszor típusú E2FC kizárólag az osztódó gyökér merisztéma sejtekben detektálható, de nemcsak a sejtmagban, hanem a citoplazmában is elöfordul. Az RBR fehérje a gyökérben mindenhol magas szinten fejeződött ki, ennek megfelelően a különböző E2F-RBR komplexek specifikusan, a gyökér más és más régióiban jöhetnek létre. 

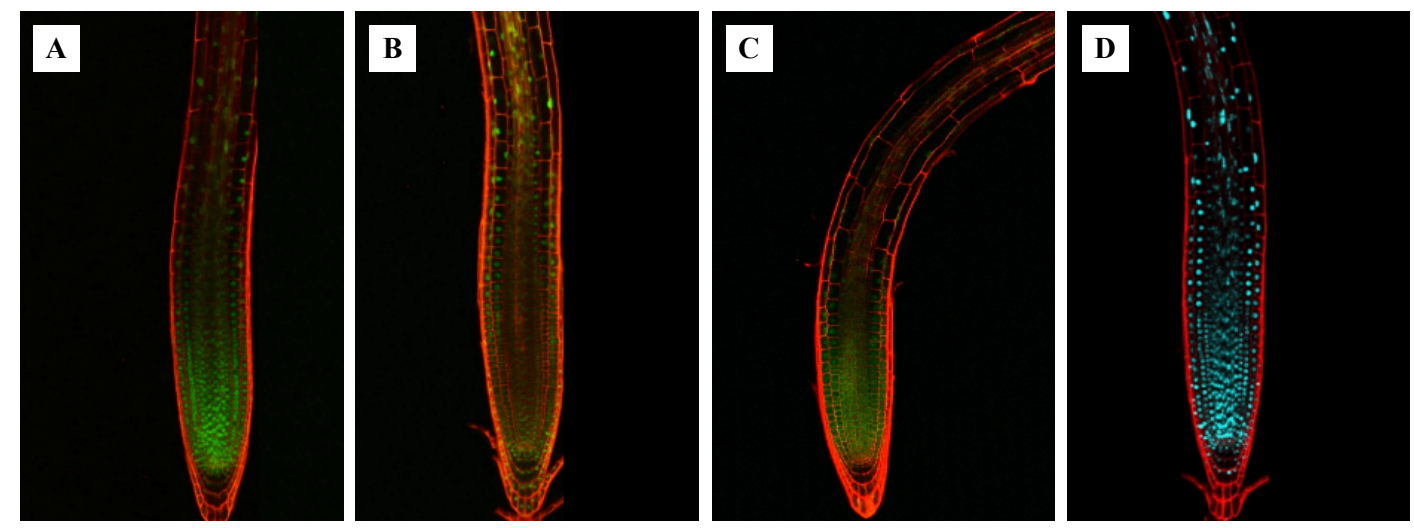

5. ábra. Az Arabidopsis E2FA, E2FB, E2FC és RBR fehérjék gyökér merisztéma-specifikus kifejeződése Transzgenikus Arabidopsis transzlációs riporter vonalak: A) pgE2FA-3xvYFP, B) pgE2FB-3xvYFP, C) pgE2FC-GFP és D) pgRBR-3xCFP. Az egyes vonalak gyökércsúcsait propídium-jodid festést követően konfokális mikroszkópia segítségével vizsgáltuk. A kísérletben a jelzett fehérjék genomikus klónjainak YFP/GFP (zöld szín; E2FA és E2FB, E2FC) vagy RBR esetében CFP (a GFP egy módosított, kék színü változata, cián fluoreszcens fehérje) riporter fehérjékkel egyesített változatai a rájuk jellemző szövetekben fejeződtek ki, miután a saját szabályozó régiójuk irányította az expressziójukat. Az E2FA és E2FB fehérjék expressziója egymás komplementere; az E2FA főleg a merisztéma centrumában, míg az E2FB inkább a gyökér proximális sejtjeiben fejeződik ki. Az RBR a gyökér merisztémában egyenletesen kifejeződő fehérje, mely így mind a három E2F transzkripciós faktor müködését szabályozhatja (Magyar és mtsai., nem közölt adatok alapján).

Hasonlóan az állatokhoz, a sejtosztódási gének expressziójára kifejtett hatásuk alapján a növényi E2F fehérjéket aktivátor (E2FA és E2FB) és represszor (E2FC) alcsoportba osztották, bár ezek a csoportosítások többnyire az E2F-ek túltermeltetési eredményeire támaszkodnak (Magyar, 2008). Az E2FA-DPA-t együttesen túltermeltető transzgenikus Arabidopsis növényekben ugyanakkor a teljes genom expresszionális vizsgálat az aktiválódó gének mellett represszálódó géneket is kimutatott. Ez arra utal, hogy a növényi E2F transzkripciós faktorok bizonyos gének esetében aktivátor, míg más gének esetében gátló funkciót tölthetnek be. Az E2FA-DPA heterodimer túltermeltetése aktiválja a sejtosztódást és késlelteti a differenciálódást, emellett a transzgenikus növények növekedése is erösen gátlódott. Érdekes módon azonban nemcsak a mitózis, hanem a differenciálódó sejtekre jellemző endociklus is aktiválódott, és ennek köszönhetően jelentősen megnőtt a ploid szint ezekben a növényekben (De Veylder és mtsai.; 2002, Magyar és mtsai., 2012). De Veylder és munkatársai egy modellt állítottak fel, ami szerint az extra E2FA belépteti a sejteket az osztódásba, miután a mennyisége meghaladja az RBR mennyiségét (De Veylder és mtsai., 2002). Azokban a sejtekben, amelyek a merisztémában vannak, a sejtciklus tovább folytatódik az M fázisban is, mivel rendelkeznek mitózis-indukáló faktorral (MIF), míg azok a sejtek, amelyek már a merisztémán kívül találhatóak, már nem rendelkeznek MIF-fel és így csak az S fázis ismétlődik. Egy másik elmélet szerint az E2FA az RBR-rel a merisztematikus, tehát osztódó sejtekben lép represszor komplexbe, és gátolja azoknak a géneknek a kifejeződését, amelyek az endociklus aktivációjában vesznek részt. Ezt az elméletet támasztotta alá, hogy az E2FA egy RBR-kötésre és transzaktiválásra képtelen mutáns változatának a túltermeltetésével az $\mathrm{S}$ fázis-specifikus gének mellett az ANAPHASE PROMOTING COMPLEX (APC) aktivátorai, a CCS52A1 és A2 (CELL CYCLE SWITCH 
PROTEIN 52 A1 és 2) is hiperaktiválódtak (Magyar és mtsai., 2012). Az APC fontos szerepet játszik az endociklus szabályozásában, mert lebontja a mitotikus ciklineket, és megakadályozza az M fázisba lépést. Ezekkel az eredményekkel összhangban kimutatták, hogy az E2FA-RBR komplex mennyisége nem csökkent, sőt emelkedett a CYCD3;1-túltermelő, erős osztódási fenotípust mutató növényekben, míg az E2FB csak RBR-mentes szabad formában volt kimutatható.

Az E2FB-DPA heterodimer túltermeltetése a növényi növekedési hormon, az auxin hiányában is aktiválta a sejtosztódást, míg az E2FA-DPA erre nem volt képes (Magyar és mtsai., 2005). Ez alapján az E2FB hasonló tulajdonsággal bír, mint az állati aktivátor E2F1, amely növekedési faktorok hiányában is képes aktiválni a DNS szintézist (Magyar és mtsai., 2005). Az E2FA és E2FB transzkripciós faktorok sejtciklusfüggő expressziója között is lényeges különbség van: amíg az E2FA kizárólag a sejtciklus S fázisában fejeződik ki, addig az E2FB a későbbi sejtciklusfázisokban is jelen van (Magyar és mtsai., 2000; Magyar és mtsai., 2005). Az E2FB ezért nemcsak az osztódásba lépést, de az M fázisba haladást is szabályozhatja. Ezzel összhangban kimutatták, hogy az E2FB szabályozza az M fázis-specifikus CDKB1;1 gén expresszióját (Magyar és mtsai., 2005; Henriques, Magyar és Bögre, 2013). Ezek az eredmények arra utalnak, hogy a két aktivátor E2F szerepe nem teljesen átfedő.

$\mathrm{Az}$ Arabidopsis RBR fehérje mind a három E2F funkcióját szabályozhatja, de a pontos mechanizmus, valamint a komplexek növekedésben és fejlödésben betöltött szerepe még nem teljesen tisztázott. Az Arabidopsis RBR funkciója esszenciális, hiányában nem képződnek egészséges ivarsejtek (Ebel, Mariconti és Gruissem, 2004) és a posztembrionális fejlődés is gátlódik (Borghi és mtsai., 2010; Gutzat és mtsai., 2011). Az RBR túltermeltetése ugyanakkor a merisztéma differenciálódásához vezet, míg az RBR funkció gátlása több őssejtet eredményez a gyökérmerisztémában és a levél zárósejtek képzésében részt vevő úgynevezett zárósejt merisztemoidokban is (Magyar, 2008; Wildwater és mtsai., 2005). Amikor az RBR funkciót az embrionális fejlödés után gátolták, a növények növekedése is gátlódott; az RBR hiányában több, de kisebb sejt keletkezett (Gutzat és mtsai., 2011). Mindez megerősíti, hogy az RBR a növények esetében is központi szerepet játszik a differenciálatlan és a differenciált állapotok közti átmenet szabályozásában. Állatokban az RB tumort indukáló hatását gátolni lehetett az E2F aktivátor transzkripciós faktorok egyidejü mutációjával (Chen, Tsai és Leone, 2009). Pontosan még nem ismert, hogy az Arabidopsis RBR szabályozás mennyire az E2F transzkripciós faktorokon keresztül érvényesül, de az eddigi eredmények alapján a növényekben is az E2F-ek az RBR elsődleges effektorai (6. ábra; Horváth és mtsai., 2017). 


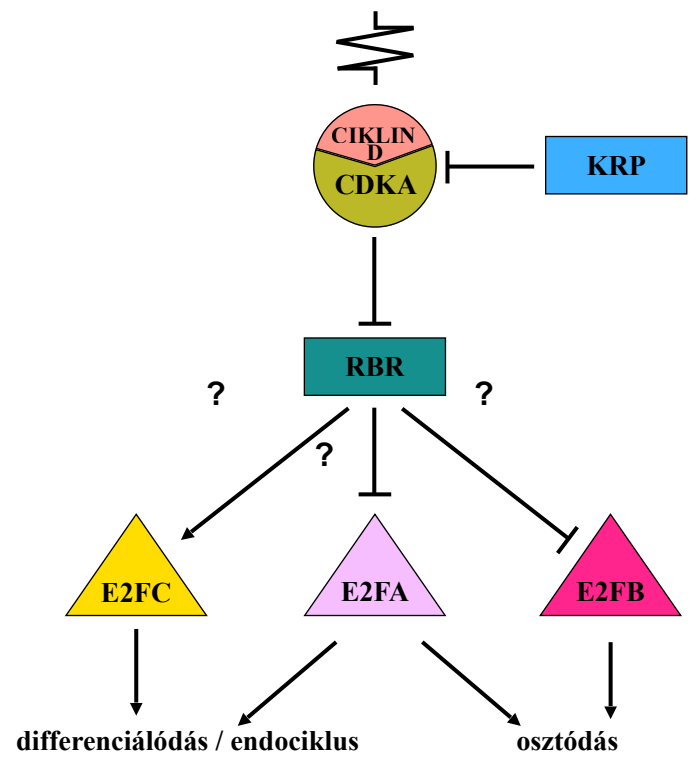

6. ábra. Az Arabidopsis E2F-RBR szabályozási modell

Növekedést stimuláló körülmények között, tápanyaggazdag környezetben és növekedést serkentő növényi hormonok, auxin és kinetin jelenlétében aktiválódik az RBR kináz (CIKLIN D - CDKA) és a sejtek belépnek az osztódásba. Növekedést gátló körülmények között, tápanyag és fény hiányában, illetve gátló hormonok jelenlétében, mint amilyen az abszcizinsav (ABA), az RBR-kináz a CDK inhibitorok (KRP) miatt inaktív marad. Az aktiválódott CIKLIN D CDK felülfoszforilálja az RBR-t, amely ebben a formájában nem képes kötni az aktivátor E2F transzkripciós faktorokat (E2FA és E2FB). Az Arabidopsis egyetlen RB-rokon fehérjéje (RBR) mind a három E2F transzkripciós faktorral képes komplexet alkotni, de a komplexek szerepe még nem igazán tisztázott (ezt jelzik a kérdőjelek; Gutierrez, 2009).

\subsection{A levél, mint a növényi szervfejlődés modellje}

Egy növényi szerv lehet folyamatosan növekvő, nem determinált méretü, mint amilyen a gyökér és szár is, és lehet determinált, melynek mérete a genetikai program által meghatározott, mint amilyen a levél és a virág. Mindkét esetben a növekedés központi „motorja” a merisztéma. A gyökér és szár esetében az osztódó sejtek és a differenciálódó sejtek között kialakul egy egyensúlyi állapot, amely többé-kevésbé egy állandó méretü csúcsmerisztémát hoz létre, amely új és új sejtekkel táplálja a folyamatosan növekvő szárat és gyökeret. A determinált növekedésű levélben a merisztematikus aktivitás temporális: a kezdeti, aktívan osztódó állapotot felváltja a sejtmegnyúlás és a differenciálódás folyamata (7. ábra; Lenhard és mtsai., 2001; Bögre, Magyar és López-Juez, 2008; Andriankaja és mtsai., 2012). A növényi sejtek gyakori differenciálódási velejárója a sejtek DNS-tartalmának (politénia) a növekedése, amely endoreduplikációval (röviden endociklus) történik (De Veylder, Larkin és Schnittger, 2011). A levél kialakulásának kezdetén minden sejt merisztematikusan aktív, úgynevezett protodermális sejt (kivétel a zárósejt, lásd később). A növekedő levélben a csúcsi sejtek lépnek ki először az osztódásból, és differenciálódni kezdenek. A levél csúcsi régiója az idő elörehaladtával egyre több és több sejtet tartalmaz, amely azt a látszatot kelti, mintha a differenciálódási front a levél alapja felé haladna (bazipetális orientáció). Amikor az epidermális levélsejtek kilépnek a mitózisból, megnyúlnak, 
és formájuk megváltozik: az egyszerủ poligonális alakból puzzle formájú, hullámos szélü, differenciált sejtekké alakulnak át (Andriankaja és mtsai., 2012; Fox és mtsai., 2018).

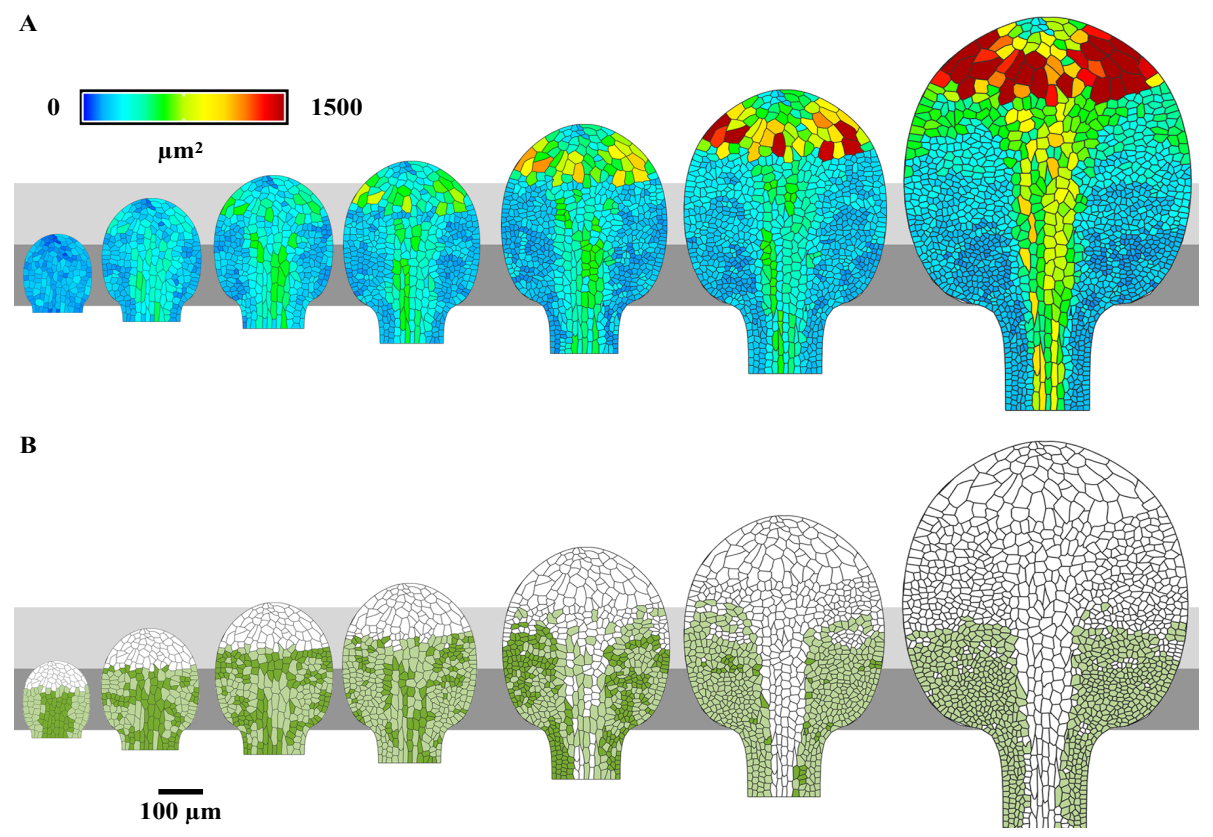

7. ábra. A levélfejlődés modellje az epidermális sejtek osztódási és megnyúlási dinamikáján keresztül

A számítógépes modell nem ábrázolja a sztóma vonal sejteket, mivel a speechless ( spch) mutáns használatával készült, annak érdekében, hogy a sztóma vonal sejtjek ne komplikálják a modellezést. Az ábra a levélfejlödés (első levél) kezdetétől számítva a 115., 132., 140., 147., 156., 164., és 178. órában ábrázolja a fejlődést. A) A virtuális sejtek méret (terület) szerinti megoszlása a fejlődő levélben (hőtérkép, a kisméretü sötétkék sejtektől a nagyméretü sötétvörös sejtekig $-\mu \mathrm{m}^{2}$ ). B) A virtuális sejtek megoszlása az osztódási potenciál alapján. Zölddel az osztódásra képes sejtek vannak jelölve. Itt különbég van a vizsgálati intervallum alatt osztódott (világoszöld) és azon sejtek között, amelyek később fognak osztódni (sötétzöld). Fehérrel a már nem osztódó sejtek vannak jelölve. A szürke zónák a levélnyél és a levéllemez kapcsolódási pontjától számított 0-150 $\mu \mathrm{m}$-es (sötétszürke) és 150-300 $\mu \mathrm{m}$-es (világosszürke) távolságot jelölik. Méret skála: $100 \mu \mathrm{m}$ (az ábrán jelezve; Fox és mtsai., 2018).

A levél epidermiszében elszórtan, mintegy diffúzan helyezkednek el a zárósejtek. A zárósejtek speciális merisztemoidokból jönnek létre, az úgynevezett zárósejt vonal alapsejtekből (stomatal lineage ground cell vagy röviden és a későbbiekben SLGC, Le J, 2014). Ezeknek a merisztemoid sejteknek az osztódása másképpen szabályozódik, mint a velük szomszédos bőrszöveti sejteké. Differenciált zárósejteket már a levélkezdeményben is meg lehet figyelni, amikor még gyakorlatilag minden más sejt osztódik, illetve SLGC-ket még akkor is lehet detektálni, amikor a többi sejt már megnyúlt és differenciálódott (Andriankaja és mtsai., 2012). Az SLGC-k aszimmetrikus osztódások révén újabb sejteket hoznak létre, amelyek zárósejtté differenciálódhatnak, vagy létrejöhet belölük differenciálódott epidermális sejt is (pavement sejt, röviden PM; 8. ábra; Lau és Bergmann, 2012). A PM sejtek fele gyakorlatilag a zárósejt vonalból jön létre. A sztóma vonal sejtek különböző fejlődési állapotait specifikus transzkripciós faktorok szabályozzák, amelyek sok esetben az RBR szabályozása alatt állnak, vagy az RBR-rel közösen más géneket regulálnak. Ilyen például a TOO MANY MOUTH (TMM) TF, amely a merisztemoid anyasejt és a zárósejt vonal alapsejtek aszimmetrikus osztódását irányítja (Nadeau 
és Sack, 2002). Az RBR szabályozza a TMM expresszióját, ezáltal serkentve a sejtek belépését a differenciálódásba (Borghi és mtsai., 2010). A FAMA (név eredete: Fama, görögül Pheme, a görög-római mitológiában a szóbeszéd, hírnév istennője) egy olyan TF, amely a zárósejt anyasejtből szabályozza az érett zárósejt keletkezését, meggátolva az osztódásba történő visszalépést (Ohashi-Ito és Bergmann, 2006). Ezt a végleges, differenciálódott állapotot az RBRrel komplexben tartja fenn, megakadályozva a korai zárósejt vonal gének expresszióját (Matos és mtsai., 2014).

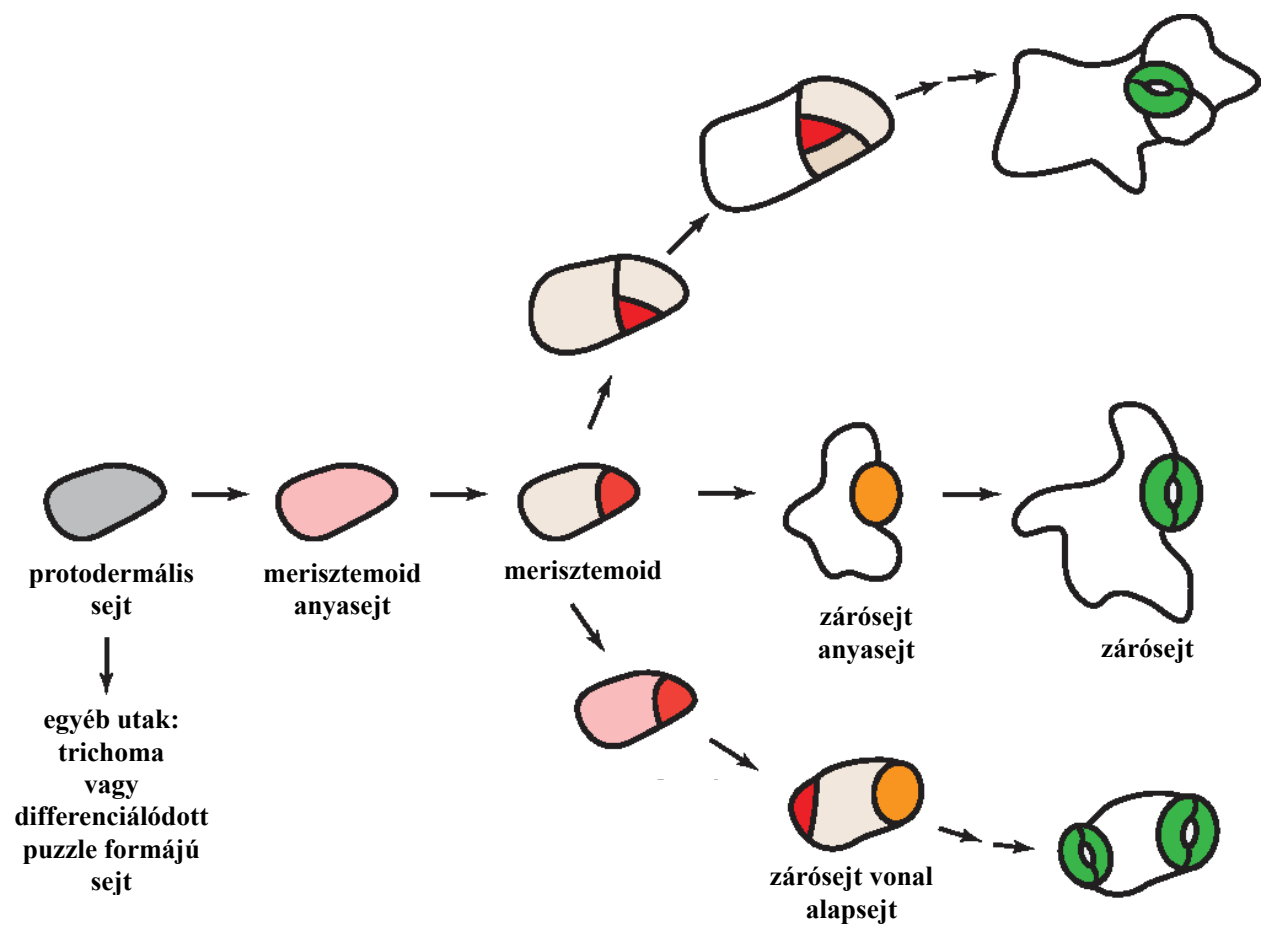

\section{8. ábra. A zárósejt vonal fejlődése az Arabidopsisban}

A protodermális sejt (szürke) elköteleződik a sztóma vonal felé, amikor merisztemoid anyasejtté válik (rózsaszín, meristemoid mother cell röviden MMC). A merisztemoid anyasejtek aszimmetrikus osztódáson mennek keresztül, és egy kisebb merisztemoid (piros), illetve egy nagyobb zárósejt vonal alapsejtet (bézs szín, stomatal lineage ground cell, röviden SLGC) hoznak létre. A merisztemoidok előtt két út áll: önmegújító aszimmetrikus osztódások, amelyek a sejtek sokszorozódását eredményezik, vagy differenciálódás sztóma anyasejtekké (narancssárga, guard mother cell röviden GMC). A sztóma anyasejtek átesnek egy szimmetrikus osztódáson, ezáltal létrehozva két zárósejtet (zöld szín, guard cell, röviden GC), amely a sztómát/gázcserenyílást szegélyezik. A sztóma vonal alapsejtek differenciálódhatnak puzzle formájú differenciálódott sejtekké, vagy merisztemoid anyasejtként létrehozhatnak egy újabb merisztemoidot és egy zárósejt vonal alapsejtet, így folytatva az osztódást (Lau és Bergmann, 2012). 


\section{CÉLKITÜZÉSEK}

A sejtosztódás és differenciálódás közti egyensúly fontos szerepet játszik a növények növekedésében, szerveik végső méretének a kialakításában. Hasonlóan az állatokhoz, a növényi retinoblasztóma fehérje is az E2F transzkripciós faktorok müködésén keresztül szabályozhatja az osztódásba lépést és a differenciálódást. Az eddigi adatok alapján az E2FB transzkripciós faktor a sejtosztódás aktivátora és ez a funkciója az RBR ellenőrzése alatt áll. Nem teljesen ismert azonban, hogy mi az E2FB pontos szerepe a növényi fejlödésben. Hogyan változik az E2FB aktivitás egy növényi szerv kialakulása során? Mutat-e szövet- és sejtspecifikus funkciót az E2FB? Ezeknek a kérdéseknek a megválaszolása érdekében különböző stratégiákat dolgoztunk ki.

1. Az Arabidopsis első levélpárja kiváló modellként szolgál a szervfejlődés, és ezen belül a sejtosztódási és differenciálódási folyamatok tanulmányozására. A levél egy ún. determinált növekedésű növényi szerv (mérete és formája jellemző egy adott növényre). Kialakulásának kezdeti, meghatározó folyamata a sejtosztódás, amelynek aktivitása a növekvő levélben egyre csökken (ún. bazipetális irányban, a levél csúcsától a levél alapja felé), majd a levél sejtmegnyúlás révén növekszik tovább. Mi a fejlődő levélben az E2FB szerepe a sejtosztódás aktiválásában és leállításában? Ennek a kérdésnek a megválaszolása céljából megvizsgáltuk, hogyan változik a levél növekedése, ha növeljük az E2FB mennyiségét és/vagy aktivitását, illetve ezzel ellentétesen mi történik az E2FB mutánsok levelében, amikor hiányos az E2FB funkciója.

2. Az E2FB elsődleges szabályozója az RBR. Az RBR müködését pedig az RBR-kinázok, elsősorban a CDKA;1-CYCD enzimek befolyásolják. Az RBR és a CYCD3;1 gének a promóter régiójukban rendelkeznek konszenzus E2F-kötő szekvenciával, ezért potenciális E2F célgének. Mi a szabályozási szerepe az E2FB-nek ezeknek az ún. E2FB upstream szabályozó géneknek a müködésében? A levélfejlődés során mikor jön létre az E2FB-RBR fehérje komplex, és mi történik ezzel a komplexszel, ha az E2FB fehérje mennyiségét többszörösére emeljük? Hogyan változik az RBR foszforilációja a levélfejlődés során?

3. Létrehoztunk egy transzgenikus Arabidopsis növényt, ahol egy olyan funkcióvesztéses E2FB-t fejeztünk ki, amelyik nem képes sem transzaktiválni, sem pedig az RBR fehérjével kölcsönhatni. Megvizsgáltuk, mi a hatása ennek a mutánsnak a levél fejlődésére.

4. Annak érdekében, hogy megtudjuk, mi történik, amikor a szabad E2FB és az E2FB-RBR komplex közti egyensúly felborul a szabad E2FB irányába, létrehoztunk olyan transzgenikus vonalakat, ahol az RBR funkciót az E2FB saját expressziós doménjében próbáltuk meg gátolni. 
Ennek során egy RBR-re specifikus mesterséges mikroRNS-t fejeztettünk ki az E2FB promóterének az ellenőrzése alatt (pE2FB::amiRBR). Találtunk egy olyan transzgenikus vonalat, ahol az RBR csendesítésére jellemző fenotípusos megnyilvánulások mellett megjelentek új makroszkópiás elváltozások is. Részletesen tanulmányoztam a mutáns növények fenotípusát, és a fenotípus mögötti molekuláris változásokat további kísérletekkel próbáltam alátámasztani.

5. Az E2FB transzkripciós faktort a levélsejtekben nemcsak a sejtmagban detektáltuk, hanem a plazmamembránhoz kapcsolódva is. Ezt a megfigyelésünket további kísérletekkel is megpróbáltam igazolni. Mi lehet a szerepe az E2FB-nek a plazmamembránban? Vannak-e az E2FB fehérjének membrán-specifikus kölcsönható partnerei? Mik ezek, és vajon az E2FB befolyásolja-e ezeknek a membrán komponenseknek a müködését? 


\section{ANYAGOK ÉS MÓDSZEREK}

\subsection{Plazmid konstrukciók és transzgenikus növények generálása}

Hagyományos molekuláris biológiai módszerekkel és Gateway (Invitrogen) technológiával történt a plazmid konstrukciók elöállítása. A kísérleteim kezdetekor a plazmid klónok és transzgenikus vonalak nagy része már rendelkezésemre állt. A nyitott olvasási kereteket (ORF) Arabidopsis thaliana cDNS templátokról, vagy genomi DNS-ről sokszoroztuk fel PCR (polimeráz láncreakció) módszerrel, a Pfu DNS polimeráz segítségével, majd a Gateway attB helyeket PCR-rel a DNS darabokhoz fuzionáltattuk. A konstrukciók promóter régiója genomi DNS-ből lett izolálva. Belépési vektorként (entry vektor) a pDON221 és pGEM-1R4, pGEMteasy 221 vektorokat használtuk (Berckmans és mtsai., 2011a; Berckmans és mtsai., 2011b; Magyar és mtsai., 2012). Célvektorként különböző Gateway vektorokat alkalmaztunk (részletezve lásd később). A konstrukciók előállítása E. coli baktériumokban történt (pl. DH5 , XL1-Blue), a kész konstrukciókat szekvenálással ellenőriztük le. A növényi transzfromálás agrobaktérium-közvetítette transzformációval, a virágokon keresztül történt. A tranziens expresszió során Nicotiana benthamiana növények levelét fecskendővel agrobaktériummal infiltráltuk. A pontos leírást lásd a 3.2 és 3.3 fejezetekben.

\subsubsection{Fluoreszcens taggel jelölt E2F transzlációs konstrukciók és transzgenikus Arabidopsis vonalaik előállítása}

A pE2FB::gE2FB-GFP (pgE2FB-GFP), pE2FA::gE2FA-GFP (pgE2FA-GFP), pgE2FB3xvYFP és pgE2FA-3xvYFP konstrukciók elkészítéséhez korábban leközölt belépési vektorokat (entry vektor) használtunk (pDON221 és pGEM-1R4, pGEMt-easy221), amelyekben az E2FB és E2FA gének szekvenciája Arabidopsis thaliana genomi DNS-ről lett felsokszorozva. A konstrukciók promóter régiója szintén genomi DNS-ből lett izolálva. A pgE2FB-GFP konstrukció esetében az E2FB genomikus klónja fuzionáltatva lett a 3' végén a GFP fluoreszcens fehérjével, és a fúziós terméket az E2FB promóter ellenőrzése alá helyeztük Gateway módszer (Invitrogen) segítségével a pGII0125 növényi transzformálásra alkalmas célvektorba (9. ábra A; Galinha és mtsai., 2007). Agrobaktérium mediált transzformációval a konstrukciót növénybe vittük, majd norfurazon szelekciós táptalajon harminchat különböző vonalat azonosítottunk. A kísérleteimhez döntően három különböző expressziós szintü vonalat választottunk ki: egy alacsonyt (61-es vonal), egy közepeset (93-as vonal), és egy magasat (72-es vonal).

A pgE2FB-3xvYFP konstrukció esetében hasonlóan jártunk el, de itt három YFP fluoreszcens molekulát füztünk az E2FB 3' végéhez (Leviczky és mtsai., 2019). Ugyanez a technika lett alkalmazva a pgE2FA-3xvYFP konstrukció elóállítása esetében is (Berckmans és mtsai., $2011 \mathrm{a}$, 
Berckmans és mtsai., 2011b; Henriques és mtsai., 2010; Magyar és mtsai., 2012; Leviczkyés mtsai., 2019).

\subsection{2. p35S:HA-E2FB-DPA ${ }^{\mathrm{OE}}$ koexpresszáló transzgenikus Arabidopsis vonalak bemutatása}

Az E2FB gén HA (influenza hemagglutinin) epitóppal ellátott változata a dohány mozaik vírus erős p35S promóterének az ellenőrzése alatt már rendelkezésemre állt (Magyar és mtsai., 2000). Ezt a konstrukciót p35S:DPA expresszáló növényekbe transzformálták be (Magyar és mtsai., 2000; de Veylder és mtsai., 2002; Horvath és mtsai., 2017). A második utódgenerációban (T1) tizenhárom vonalat azonosítottak kanamicin tartalmú táptalajon, és a későbbiek során egy erősen koexpresszáló homozigóta vonallal dolgoztam tovább (p35S:HA-E2FB-DPA ${ }^{\text {OE }}$ 10-es vonal).

\subsubsection{Deléciós E2F konstrukciók előállítása}

Ez a HA-epitóp taggel ellátott mutáns E2FB konstrukció is már rendelkezésemre állt (Magyar és mtsai., 2000). Ez a mutáns E2FB (E2FB $\left.{ }^{\triangle R B R}\right)$, amelynek C-terminális végéről az utolsó 84 aminosav hosszúságú kódoló szakaszt deletálták (9. ábra A, ez tartalmazza a transzaktivációért felelös szakaszt, valamint a konzervált RBR-kötő régiót), a pK7WG2 gateway vektorba lett beklónozva, és konstitutív 35S dohánymozaik-vírus promóter ellenőrzése alá vonva (Magyar és mtsai., 2000). Az így elkészült konstrukció a p35S:DPA transzgenikus növényekbe lett bejuttatva

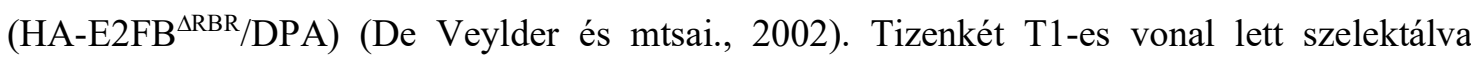
kanamicin tartalmú táptalajon, és ezekből két homozigóta vonalat jellemeztünk részletesebben (HA-E2FB ${ }^{\triangle \mathrm{RBR}} / \mathrm{DPA} 1$ és 10 transzgenikus vonal). További deléciós konstrukciókat hoztunk létre, ahol hosszabb szakaszokat deletáltunk az E2FB és az E2FA kódoló szekvenciáiból. Ez az E2FA esetében 135 (9. ábra B), míg az E2FB esetében 160 aminosav hosszúságú C-terminális régiót jelentett (9. ábra). A konstrukciókhoz N-terminálisan GFP fehérjét fuzionáltunk $\left(G F P-E 2 F^{\triangle R B R 2}\right.$ és GFP-E2FA ${ }^{\triangle R B R 2}$ ). Ezeket a növényi transzformációs vektorba klónoztuk (pK7WGF2), és Arabidopsisba transzformáltuk öket. Mindkét esetben 15 független vonalat azonosítottunk kanamicin szelekción. Továbbá készítettünk még egy deléciós E2FB mutáns konstrukciót, amely esetében 258 aminosav hosszúságú kódoló szakaszt deletáltunk a fehérje Cterminális végéröl $\left(\mathrm{E} 2 \mathrm{FB}^{\triangle \mathrm{MB}}, 9\right.$. ábra $\left.\mathrm{A}\right)$. Ezt konstitutív p35S vírus promóter irányítása alá klónoztuk a pK7WG2 Gateway vektorba (Karimi, Inzé és Depicker, 2002). Ezt a konstrukciót Nicotiana benthamiana növények levéltranszformálására használtuk fel (lásd később). 
A

E2FB

E2FB $^{\triangle R B R}$

E2FB $^{\triangle R B R 2}$

E2FB $^{\Delta M B}$

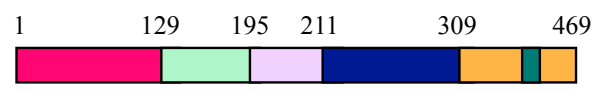

$\begin{array}{lllll}1 & 129 & 195 & 211 & 309\end{array}$

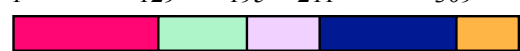

$\begin{array}{lllll}1 & 129 & 195 & 211 & 309\end{array}$

1

$\begin{array}{lll}129 & 195 \quad 211\end{array}$

B

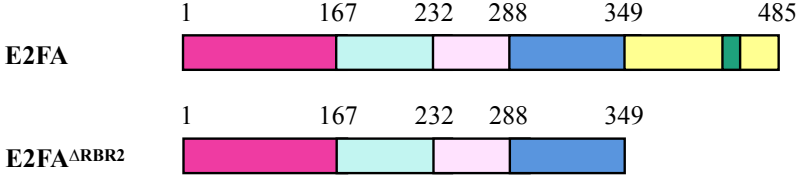

9. ábra. A dolgozatban használt különböző E2FB és E2FA konstrukciók

Az A) E2FB és B) E2FA konstrukciók domén szerveződése. A különböző színek az eltérő doméneket jelölik az E2Fen belül. Ciklámen $=$ N-terminális régió, mentazöld $=$ DNS-kötő domén, rózsaszín $=$ dimerizációs domén, kék $=$ marked box, sárga = transzaktivációs domén, zöldeskék = RBR kötő domén. (De Veylder és mtsai., 2002).

\subsubsection{E2F T-DNS inszerciós funkcióvesztéses mutánsok}

Az E2F T-DNS (transzfer DNS) inszerciós mutánsok a SALK Intézetből és a Max Planck Növénynemesítő Kutatóintézetből Prof. Dr. Koncz Csabáék gyüjteményéből származnak (e2fb1 [SALK_103138], e2fb-2 [SALK_120959], e2fa-1 [MPIZ-244], e2fa-2 [GABI-348E09], Berckmans és mtsai., 2011a; Heyman és mtsai., 2011; Horvath és mtsai., 2017; Leviczky és mtsai., 2019). A különböző $E 2 F A$ és $E 2 F B$ génekben a T-DNS inszerció helyeit az E2FB és az E2FA fehérje doménjeire vetítve a 10. ábra mutatja be.

$\mathbf{A}$

E2FB

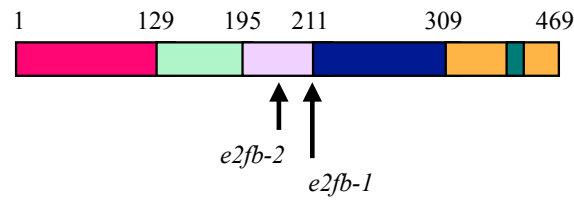

B

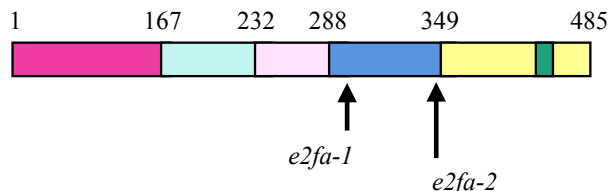

10. ábra. A dolgozatban használt T-DNS inszerciós $e 2 f a$ és $e 2 f b$ mutánsok szerkezetében bekövetkezett változások

Az A) $E 2 F B$ és B) $E 2 F A$ génekbe beépült T-DNS által okozott funkcióvesztések. Az E2F fehérjékben különböző színekkel jelöltük a funkcionális doméneket: ciklámen $=\mathrm{N}$-terminális régió, mentazöld $=$ DNS kötő domén, rózsaszín $=$ dimerizációs domén, kék $=$ marked box, sárga $=$ transzaktivációs domén, zöldeskék $=$ RBR-kötő domén (De Veylder és mtsai., 2002). A nyilak a T-DNS beépülési helyét jelölik.

Az e2fab dupla mutáns az e2fa-2 és e2fb-1 T-DNS inszerciós növények keresztezéséből származik (Heyman és mtsai., 2011; Leviczky és mtsai., 2019). 
Az e2fb-2 T-DNS inszerciós Arabidopsis mutánsba agrobaktérim közvetítette transzformáció segítségével vittük be a pgE2FB-GFP konstrukciót, majd szelekción (norflurazon) transzformáns vonalakat azonosítottunk. Két homozigóta vonallal foglalkoztunk részletesebben (e2fb$2[\mathrm{pgE} 2 \mathrm{FB}-\mathrm{GFP}] 4$ és 6 vonalak).

\subsubsection{Mesterséges mikroRNS konstrukciók készítése az RBR csendesítésére, és transzgenikus növények előállítása}

Az RBR gátlása egy specifikus, 21 nukleotid hosszúságú, mesterségesen előállított mikroRNS (amiRNS) segítségével történt, ami az RBR mRNS 3' végi nem transzlálódó szakaszára (UTR) lett tervezve (amiRBR; 11. ábra; Cruz-Ramírez és mtsai., 2013). Az amiRBR mikroRNS-kódoló szekvencia különbözö E2F promóterekkel lett összekapcsolva (pGII125 vektorban). A dolgozatban az E2FC és az E2FB promóterek által irányított amiRBR transzgenikus vonalakat használtuk (pE2FC::amiRBR és pE2FB::amiRBR).

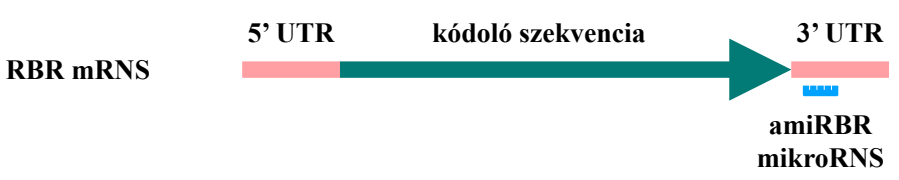

11. ábra. Az RBR funkciót gátló mesterséges mikroRNS grafikus ábrázolása

A rózsaszín szakaszok jelzik az RBR mRNS nem transzlálódó szekvenciáit (untranslated region, 3' és 5' UTR); zöld szakasz jelzi a kódoló szekvenciát (coding sequence, CDS). A 21 nukleotid hosszúságú mikroRNS (amiRBR, kékkel jelzett szakasz) az RBR 3' UTR régiójában helyezkedik el.

\subsubsection{A PIN3-GFP konstrukció előállítása}

A pgPIN3-GFP transzlációs konstrukció előállítása során egy a BAC F15H11-ből előállított és NgoM IV-gyel emésztett 12,5 kb nagyságú PIN3 genomi fragmentum a pBIN19 bináris vektor XmaI helyére lett klónozva (Zádníková és mtsai., 2010). A GFP fragmentum a PIN3 első exonjához lett fuzionálva a Counter-Selection BAC Modification Kit (Gene Bridges) használatával, majd Arabidopsis növénybe lett transzformálva (Zádníková és mtsai., 2010).

\subsubsection{PIN3-RFP konstrukció előállítása}

A PIN3 kódoló szekvencia cDNS-ről PCR-ral lett felamplifikálva és a pCR8-GW-TOPO vektorba lett beklónozva. A pK7WGR2 növényi transzformációs vektorba Gateway rekombinációval lett tovább klónozva, a 35S promóter mögé, a piros fluoreszcens proteinnel (RFP) a C-terminálisán fuzionálva. A konstrukciót a Fribourgi Egyetemről kaptuk Dr. Markus Geislerék laboratóriumából. 


\subsection{Arabidopsis thaliana növények transzformációja virág merítéses agroinfiltráció módszerével}

Az Arabidopsis növényeket üvegházban neveltük hosszú nappalon (16 óra fény/8 óra sötét). A virágzást követően visszavágtuk őket, hogy több másodlagos virágzatot hozzanak. A transzformáns agrobaktériumot, amely tartalmazta a célgént hordozó konstrukciót, folyadék kultúrában, antibiotikum jelentlétében, $28{ }^{\circ} \mathrm{C}$-on növesztettük $\left(\mathrm{OD}_{600}=0,8\right)$, majd a baktériumokat centrifugálással összegyüjtöttük, és 5\%-os transzformációs cukoroldatba felvettük őket Silwet L-77 jelenlétében (koncentráció: $500 \mu 1 / 1$ ). A növények virágzatát az agrobaktériumos transzformáló oldatba merítettük (10 másodperc/növény), majd tálcára fektetve, a sötét és a magas páratartalom biztosítása érdekében alufóliával letakarva 1 napig inkubáltuk őket. Ezt követően egy hétig még mérsékelt fényviszonyok között neveltük őket, majd megismételtük a transzformálás folyamatát. A magok beérését követően a magokat a vektor által hordozott szelekciós génnek megfelelően antibiotikum vagy herbicid jelenlétében csíráztattuk (Bechtold, Ellis és Pelletier, 1993; Clough és Bent, 1998; Zhang és mtsai., 2006).

\subsection{Nicotiana benthamiana növényi levelek agroinfiltrációja}

A célgén tranziens kifejeztetése céljából 6-8 hetes Nicotiana benthamiana növények leveleit használtuk. A célgént hordozó agrobaktérium törzset antibiotikumot tartalmazó folyadék kultúrában, $28{ }^{\circ} \mathrm{C}$-on növesztettük $\left(\mathrm{OD}_{600}=0,8\right)$. A baktérium sejteket centrifugálással összegyüjtöttük, és $10 \mathrm{mM}$ 2-(Nmorfolino)-etán-szulfonsav (MES, pH 5,6) $30 \mathrm{mM} \mathrm{MgCl}_{2}$ és $150 \mu \mathrm{M}$ acetosziringon tartalmú oldatba vettük fel öket, úgy, hogy a baktérium sürüsége ne változzon meg $\left(\mathrm{OD}_{600}=0,8\right)$. Egy gén infiltrációja esetében egy olyan oldatot készítettünk, ahol 2:1 arányban elegyítettük a célgént tartalmazó agrobaktérium és az RK19-es agrobaktérium törzseket, amely tartalmazta a 19K csendesítés-gátló (anti-silencing) fehérjét. A növények gyakran reagálnak poszttranszkripciós géncsendesítéssel (PTGS) vagy RNS-mediált védekezéssel (RMD) a különböző fertőzésekre, hogy gátat szabjanak a terjedésüknek, ennek a mechanizmusnak az elnyomásában segít a 19K fehérje. Két gén együttes kifejezéséhez (kotranszfekció) a transzformáns agrobaktérium törzseket az RK19 agrobaktérium sejtekkel 1:1:1 arányban elegyítettük. 3-4 óráig szobahőmérsékleten óvatos rázatás mellett inkubáltuk őket, majd fecskendő segítségével a levél abaxiális oldalán a dohánylevélbe injektáltuk (infiltráció). A mikroszkópos analízis és a mezofill sejt protoplaszt készítés a levelekből 3-4 nappal az infiltrációt követően történt (Voinnet, Pinto és Baulcombe, 1999; Vlot és mtsai., 2001).

\subsection{In vitro növény kultúrák és kísérleti növényi anyag előállítása}

Kísérleti növényünk az Arabidopsis thaliana Columbia ökotípus volt, és a különbözö transzgenikus és mutáns vonalaink ebben az Arabidopsis háttérben készültek (lásd korábban). A sterilizálás során a magokat 1 percig 96\%-os etanolban áztattuk, ezt követően 12 percig 5\%-os 
Domestos oldatban rázattuk, majd steril vízzel többször átmostuk (Clough és Bent, 1998). A steril magokat sötétben 1 napig $4{ }^{\circ} \mathrm{C}$-on hidegkezeltük. Alap táptalajként feles erősségú csírázási médiumot (1/2GM) használtunk, melynek alkotói Murashige \& Skoog tápanyag, szacharóz (VWR), MES (Duchefa), és amelyet Milli-Q vízzel egészítettünk ki. Az agar mennyisége változott attól függően, hogy vízszintes vagy függőleges lemez öntésére használtuk (6 g/l vízszintes, $8 \mathrm{~g} / 1$ függőleges lemez készítése esetén). A kiültetésre szánt növények táptalajához agar helyett Phytagel-t használtunk (4 g/l). A táptalaj pH-ját 5,8-ra állítottuk be kálium-hidroxid oldat $(\mathrm{KOH})$ segítségével. A növényeket folyamatos fényen neveltük $100 \mu \mathrm{E} / \mathrm{m}^{2}$ s fényintenzitás mellett in vitro steril körülmények között, $22{ }^{\circ} \mathrm{C}$-os hömérsékleten. A három hétnél idösebb növényeket üvegházban speciális talajkeveréken (Plantobalt; Plantaflor Humus Verkaufs$\mathrm{GmbH}$ ) hosszú nappalon (16 h megvilágítás /8 h sötét) neveltük tovább, az in vitro növesztéssel megegyező fény- és hőmérsékleti kamrabeállítások mellett.

A sziklevelek és az első levélpár begyüjtéséhez a vad típusú és transzgenikus (p35S:HAE2FB/DPA， pgE2FB- GFP， és p35S:HA-E2FB ${ }^{\triangle R B R} / D P A ， e 2 f b-2 / p g E 2 F B-G F P$, pE2FB:amiRBR) növényeket in vitro, steril körülmények között növesztettük, és 8-15 nappal a csírázást követően különböző időpontokban mintákat vettünk. A mintákat folyékony nitrogénnel fagyasztottuk, majd $-80{ }^{\circ} \mathrm{C}$-on tároltuk.

\subsection{Mikroszkópos analízis}

\subsubsection{Levél agaróz lenyomat készítés}

A tárgylemezekre 3\%-os forró, alacsony olvadáspontú agaróz oldatot cseppentettünk, majd a még olvadt állapotú agarózra fektettük rá a szik- illetve valódi leveleket (első levélpár) az abaxiális oldalukkal lefelé. Az agaróz megszilárdulását követően a mintákat óvatosan eltávolítottuk a megszilárdult agaróz felületéről és a lenyomatukat fedőlemez nélkül differenciális interferencia kontraszt fény mikroszkóp (DIC) alatt megvizsgáltuk (Optiphot 2, Nikon, Horiguchi és mtsai., 2006; Christensen, 2010).

\subsubsection{Gyökércsúcs Lugol festése}

A gyökérsüveg sejtjeinek bazális részén találhatóak a sztatolitok vagy amiloplasztok, amelyek a gravitropizmusért felelős keményítőszemcséket tartalmazzák. A keményítő, poliszacharid révén D-glukóz alapegységekből épül fel, amelyek $\alpha$-1-4-es kötést tartalmazó amilózt, és $\alpha-1-4$ és 1-6os kötést tartalmazó amilopektint képeznek, egy helikális szerkezetet biztosítva. A Lugol oldat jódtartalmának köszönhetően bejut a cukormolekulák által alkotott spirál belsejébe, majd a jodidionok és a keményítőmolekulák között elektron donor-akceptor kölcsönhatás alakul ki, így a megfestett keményítőszemcséknek más lesz a fényelnyelési tartománya (Bonechi és mtsai., 
2017). A gyökereket 30 másodpercre Lugol oldatba (Sigma) helyeztük, majd tárgylemezre rakva klorálhidrát oldattal (klorálhidrát : glicerol : víz 8:3:1 arányban) jégen 5-10 percig fixáltuk, mielött mikroszkóp alatt megvizsgáltuk volna őket (Hong és mtsai., 2015).

\subsubsection{Levél és gyökér szövetek propídium-jodid festése és konfokális mikroszkópos analízise}

A propídium-jodid (PJ) egy olyan fluoreszcens anyag, amely kötődik a sejtfalat jelentős részben alkotó homogalakturon láncok karboxil csoportjaihoz, így a sejtfal jól detektálhatóvá válik konfokális mikroszkóp segítségével (Rounds és mtsai., 2011). Kísérleteink során 20 mg/ml-es propídium-jodid törzsoldatot használtunk (Sigma, végkoncentráció $0,4 \mathrm{mg} / \mathrm{ml}$ ). A növényi szöveteket konfokális lézer mikroszkóp (SP5, Leica) alatt vizsgáltuk, $543 \mathrm{~nm}$ gerjesztés mellett, ahol a propídium-jodid emissziója 580-630 nm közé esik.

\subsubsection{Gyökerek EdU (5-Etinil-2-DeoxiUridin) festése}

A növényeket $1 \frac{1}{2}$ GM táptalajon növesztettük, majd EdU-t tartalmazó oldatba raktuk át öket, és 3 óráig inkubáltuk. Ezt követően a növényeket 1\% formaldehid és $0,1 \%$ Triton X-100 tartalmú foszfát puffer (PBS) oldatban fixáltuk. Majd Click-iT EdU staining kitet (C10338, Invitrogen) használtunk a jeldetektációhoz a mikroszkópos analízis elött (Kotogány és mtsai., 2010; CruzRamírez és mtsai., 2013).

\subsubsection{A különböző fluoreszcens tagek konfokális lézermikroszkópos analízise}

Az általunk használt különböző fluoreszcens fehérjék detektálási paramétereit a 2. táblázat foglalja össze. Az adatok a Nikon MicroscopyU oldaláról származnak (https://www.microscopyu.com).

A növényi szövetek vizsgálata konfokális lézer mikroszkóppal (SP5, Leica) történt.

\begin{tabular}{|c|c|c|c|c|c|}
\hline fehérje & $\begin{array}{c}\text { gerjesztő lézer } \\
(\mathbf{n m})\end{array}$ & $\begin{array}{c}\text { gerjesztési szürö } \\
\mathbf{C W L / B W}(\mathbf{n m})\end{array}$ & $\begin{array}{c}\text { dikromatikus tükör } \\
(\mathbf{n m})\end{array}$ & $\begin{array}{c}\text { emissziós szürö } \\
\text { CWL/BW (nm) }\end{array}$ & $\begin{array}{c}\text { relatív fényesség } \\
\text { (\%) }\end{array}$ \\
\hline GFP & Argon (488) & $450 / 50$ & $480 \mathrm{LP}$ & $510 / 50$ & 48 \\
\hline Venus (vYFP) & Argon (514) & $495 / 35$ & $515 \mathrm{LP}$ & $545 / 40$ & 156 \\
\hline DsRed (RFP) & He-Ne (543) & $540 / 45$ & $570 \mathrm{LP}$ & $600 / 50$ & 176 \\
\hline
\end{tabular}

2. táblázat. Fluoreszcens fehérjék detektálási paraméterei

A gerjesztés a különböző fehérjék esetében különböző lézerrel történt. A gerjesztő lézer neve melletti számérték a gerjesztő lézer fényének hullámhosszát jelöli. A CWL és BW a gerjesztési és emissziós szürő paraméterei: CWL (center wavelength = középsö hullámhossz), BW (bandwidth = sávszélesség). A dikromatikus tükörhöz tartozó értékek a felül áteresztő (LP =longpass) szürő levágási hullámhosszai; az érték alá eső hullámhossztartományba eső fényt a dikromatikus tükör nem engedi át. A relatív fényesség a fehérjék által kibocsátott fény EGFP által kibocsátott fényhez viszonyított relatív intenzitása. 


\subsection{A levél kinematikai jellemzése}

A vad típusú és a transzgenikus Arabidopsis vonalak leveleit vizsgáltuk (első levélpár, 8, 10 és 12 nappal a csírázást követően) és közvetlenül a leszedés után propídium-jodiddal festettük a sejteket. A mikroszkópiás képeket a levelek abaxiális oldaláról 3 különböző zónában (a levél bazális, mediális és csúcsi régiója) készítettük. A 3 különböző zónában 600-600 sejt méretét (terület) és cirkularitási indexét határoztuk meg. Minden vonalból legalább 3 levél került elemzésre az ImageJ szoftver segítségével (Andriankaja és mtsai., 2012). A különböző paraméterek meghatározása a következő képletek felhasználásával történt: (Asl és mtsai., 2011):

A sejtek átlag méretének (területének) meghatározására a következő képletet használtuk:

$$
s^{i}=\frac{a_{1}}{N^{i}\left(a_{1}\right)}
$$

ahol, $i=$ a levelek gyüjtésének időpontja

$s=$ a sejtek átlag mérete

$a_{1}=$ a leszámolt terület mérete

$N^{i}\left(a_{l}\right)=$ a leszámolt sejtek száma, beleértve az epidermális sejteket és a zárósejteket egyaránt

Egy levélben található átlag sejtszám:

$$
N^{i}\left(a_{2}\right)=\frac{a_{2}}{s^{i}}
$$

ahol, $a_{2}=$ a levél átlag mérete

$s^{i}=$ a sejtek átlag mérete adott időpontban

Zárósejt index:

$$
S I^{i}=\frac{N_{G C}^{i}\left(a_{1}\right)}{N^{i}\left(a_{1}\right)}
$$

ahol, $N_{G C}^{i}\left(a_{1}\right)=$ leszámolt zárósejtek száma az $a_{l}$ területen

$N^{i}\left(a_{1}\right)=$ a leszámolt sejtek száma, beleértve az epidermális sejteket és a zárósejteket egyaránt

Egy levélben található átlag zárósejt szám:

$$
N^{i}{ }_{G C}\left(a_{2}\right)=S I^{i} N^{i}\left(a_{2}\right)
$$

ahol, $\mathrm{SI}^{\mathrm{i}}=$ zárósejt index

$$
\mathrm{N}^{\mathrm{i}}\left(\mathrm{a}_{2}\right) \text { = egy levélben található átlag sejtszám }
$$


Egy levélben található átlag epidermális sejt (az epidermiszben található összes sejttípus, kivéve a zárósejtek) szám:

$$
N_{P C}^{i}\left(a_{2}\right)=N^{i}\left(a_{2}\right)-N_{G C}^{i}\left(a_{2}\right)=N^{i}\left(a_{2}\right)\left(1-S I^{i}\right)
$$

ahol, $\mathrm{N}^{\mathrm{i}}\left(\mathrm{a}_{2}\right)=$ egy levélben található átlag sejtszám

$\mathrm{N}_{\mathrm{GC}}^{\mathrm{i}}\left(\mathrm{a}_{2}\right)$ = egy levélben található átlag zárósejtszám

$\mathrm{SI}^{\mathrm{i}}=$ zárósejt index

A sejtek méret szerinti eloszlásának vizsgálata során kizárólag az epidermális sejteket vettük figyelembe. (Asl és mtsai., 2011). Az extra sejtosztódásokat (amikor a már megnyúlt puzzle formájú sejtekben új, egyenes sejtfal jelent meg) leszámoltuk területenként, és a következő képlet alapján extrapoláltunk a teljes levélre:

Extra sejtosztódások egy levélre vonatkoztatva:

$$
D\left(a_{2}\right)=\frac{a_{2}}{a_{1}} D\left(a_{1}\right)
$$

ahol, $a_{1}=$ a leszámolt terület mérete

$a_{2}=$ a levél átlag mérete

$D\left(a_{1}\right)=$ a leszámolt extra osztódások száma $a_{1}$ területen

\subsection{A sejtek DNS tartalmának meghatározása áramlási citometriával}

Az áramlási citometriás vizsgálathoz a növények első levélpárja lett legyüjtve. A leveleket $(\sim 0.5$ $\mathrm{cm}^{2}$ ) extrakciós pufferbe (CyStain UV Precise P kit) raktuk, majd borotvapengével felszeleteltük, 5 percig inkubáltuk, majd a mintákat $50 \mu \mathrm{m}$ szövésü filteren átszürtük. A minták festése 4',6diamino-fenilindol (DAPI) felhasználásával történt. A kész mintákat Partec PAS II áramlási citométer segítségével analizáltuk (Magyar és mtsai., 2005).

\subsection{Immunoblott analízis}

A folyékony nitrogén alatt porrá tört növényi anyagot (csíranövény, első levélpár, sziklevelek) extrakciós pufferrel (25 mM Tris- $\mathrm{HCl}, \mathrm{pH} 7,5,75 \mathrm{mM} \mathrm{NaCl}, 15 \mathrm{mM} \mathrm{MgCl} 2,15 \mathrm{mM}$ etilénglikol-bisz (2-aminoetil-éter)-N,N,N',N'-tetraecetsav (EGTA), $15 \mathrm{mM}$ p-nitrofenilfoszfát, 60 $\mathrm{mM} \beta$-glicerofoszfát, $1 \mathrm{mM}$ ditiotreitol, 0,1\% (v/v) IGEPAL CA- 630, 0,5 mM NaF, $1 \mathrm{mM}$ fenilmetilszulfonil fluorid, fluorid és 1× proteáz inhibitor koktél - P9599, Sigma) tártuk fel (összfehérje). Megmértük a fehérjeoldatok koncentrációját Bradford reagenssel, majd a mintákat egyenlő mennyiségben és térfogatban vittük fel az SDS-PAGE (nátrium-dodecil-szulfát poliakrilamid gélelektroforézis) gélre (10\%-os vagy $12 \%$-os géleket használtunk). A 
molekulasúly szerint elválasztott fehérjéket polivinilidén difluorid membránra (PVDF Millipore) transzferáltuk át. A membránra átkerült fehérjéket Ponceau-S festékkel tettük láthatóvá (Sigma, 5 perc inkubálás szobahőmérsékleten). A membránt 5\%-os (w/v) tejpor és 0,05\% (v/v) Tween 20 tartalmú blokkoló oldatban (TBST; $25 \mathrm{mM}$ Tris-HCl, $\mathrm{pH}$ 8.0, $150 \mathrm{mM}$ $\mathrm{NaCl}$; és Tween 20), szobahőmérsékleten telítettük folyamatos rázás mellett egy órán keresztül. Rendszerint a membránt az első ellenanyagot tartalmazó 5\% (w/v) tejpor tartalmú TBST oldatban egy éjszakán keresztül inkubáltuk, folyamatos rázatás mellett $4{ }^{\circ} \mathrm{C}$-on. A következő elsődleges ellenanyagokat használtuk: csirke anti-RBR ellenanyag (1:2000 hígításban; Agrisera), egér monoklonális anti-PSTAIRE ellenanyag (1:40000 hígításban, CDKA;1-specifikus; Sigma), nyúl poliklonális ellenanyag anti-CDKB1;1 (1:2000 hígításban), egérben termelt monoklonális anti-GFP ellenanyag (Roche), foszfo-RB-specifikus (Ser-807/811) nyúl poliklonális ellenanyag (1:500 hígításban; Cell Signaling Tech), anti-DPA és anti-DPB nyúlban termelt poliklonális ellenanyagok, anti-E2FB nyúl poliklonális ellenanyag (1:400 hígításban) és patkányban termelt anti E2FA poliklonális ellenanyag (Magyar és mtsai., 2005; Magyar és mtsai., 2012; Leviczky és mtsai., 2019). Az elsődleges ellenanyaggal történő kezelést követően a membránt háromszor 10 percig mostuk TBST-ben, ezt követően egy óráig szobahőmérsékleten inkubáltuk a megfelelő másodlagos ellenanyagban $(2,5 \% \mathrm{w} / \mathrm{v}$ tejpor-TBST, anti-nyúl, anti-csirke és anti-egér, amelyek HRP - torma peroxidáz konjugált ellenanyagok). Végül háromszori TBST mosással eltávolítottuk a felesleges, nem kötődő ellenanyagot.

Ezt követte a kemilumineszcens szubsztrát hozzáadása (SuperSignal West-Pico Plus; Thermo Scientific vagy Immobilon Western; Millipore), amellyel öt percig inkubáltuk a membránt. A membránra fényérzékeny filmet helyezünk.

\subsection{Immunoprecipitálás}

Az immunoprecipitálás során egyenlő mennyiségü, az előzőekben leírt feltárási módszerrel elöállított összfehérjét (500-800 ㅆg között - levél, néhány napos csíranövény, sziklevél) inkubáltunk specifikus ellenanyaggal ( $2 \mu 1$ affinitás kromatográfiával tisztított ellenanyag), vagy GFP-csapda mágneses agaróz gyöngyökkel (8-10 $\mu$; ChromoTek; abban az esetben, ha a mintákat tömegspektrometriai analízisre készítettük, Miltenyi Biotec $\mu \mathrm{MACS}$ izoláló kitet használtunk), 40 perctől 1 óráig terjedő időintervallumban, $4^{\circ} \mathrm{C}$-on, állandó kevertetés mellett. A következő ellenanyagokat használtuk a koimmunoprecipitációs kísérletek során: anti-E2FB, anti-DPA, anti-DPB, anti-GFP monoklonális egér ellenanyag (Roche) vagy GFP-csapda mágneses agaróz gyöngyökhöz fuzionálva (ChromoTek, Magyar és mtsai., 2005; Umbrasaite és mtsai., 2010). Protein A-t és protein G-szefarózt (Protein-A vagy Protein-G Sepharose; Pharmacia) használtunk a monoklonális és poliklonális ellenanyagok megkötéséhez, majd a gyöngyöket extrakciós pufferrel mostuk egymást követően háromszor. A komplexek leoldása 
SDS minta pufferben történt a minták 5 perces forralása során. Az így kinyert fehérjéket SDSPAGE (SDS-Poli-acrylamid 10\%- vagy 12\%-os acrylamid töménységü) gélekre vittük fel, és a fent leírt immunoblottolási eljárást alkalmaztuk (Henriques és mtsai., 2010).

\subsection{In vitro hiszton $H 1$ kináz aktivitási teszt}

A hiszton H1 kináz aktivitási teszt (kinase assay) során a 8-15 nappal a csírázást követően legyüjtött növényeket vagy leveleket folyékony nitrogénben lefagyasztottuk, majd $-80{ }^{\circ} \mathrm{C}$-on tároltuk. Az előzőekben leírtak alapján összfehérje kivonatot készítettünk a növényi mintákból, majd mindegyik mintából azonos mennyiségü fehérjét inkubáltunk $100 \mu \mathrm{l}$ a CDK-k kötésére alkalmas $25 \%(\mathrm{v} / \mathrm{v})$ p $13^{\text {Suc1 }}$-szefaróz gyönggyel egy órán át, $4^{\circ} \mathrm{C}$-on, rázatás mellett (Magyar és mtsai., 1997). Az inkubációt követően a gyöngyöket a mosó puffer segítségével háromszor mostuk. A kináz reakciót $30 \mu 1$ reakció mix hozzáadásával indítottuk, amely $1 \mathrm{mg} / \mathrm{ml}$ hiszton $\mathrm{H} 1$ fehérje kináz szubsztrátot és 2,5 $\mu \mathrm{Ci} \gamma$-32P-ATP-t tartalmazott (Magyar és mtsai., 1997).

\subsection{Membrán preparáció differenciál centrifugálással}

A kísérletet 12 napos csíranövényeken végeztük, a kiindulási anyag friss tömege 2 gramm volt, amelyet $10 \mathrm{ml}$ jéghideg feltáró pufferben tártunk fel $(50 \mathrm{mM}$ Tris- $\mathrm{HCl}, \mathrm{pH}$ 7,5; $1 \mathrm{mM}$ etiléndiamin-tetraecetsav (EDTA), $\quad \mathrm{pH} \quad 8,0 ; \quad 350 \quad \mathrm{mM}$ szaharóz; $1-2 \quad \mathrm{mM} \quad$ PMSF (fenilmetilszulfonilfluorid); $1 \mathrm{mM}$ dithiothreitol (DTT); 1× proteáz inhibitor koktél - P9599, Sigma). Az így kapott kivonatot 22-25 ㅆm szövésủ hálón átszürtük, és a sejt organellumokat különböző erősségü centrifugálások során szétválasztottuk. Az első centrifugálással $(1000 \mathrm{~g} 5$ percig, $4^{\circ} \mathrm{C}$-on) eltávolítottuk a sejttörmelékeket (csapadék), és a felülúszó tartalmazta a teljes sejtkivonatot (totál extrakt). A teljes sejtkivonatot tovább centrifugáltuk $\left(5000 \mathrm{~g}, 10\right.$ perc, $\left.4^{\circ} \mathrm{C}\right)$, melynek révén a sejtmagok és a kloroplasztiszok az üledékbe kerültek. A kapott felülúszó további centrifugálásával $\left(15000 \mathrm{~g}, 15\right.$ perc, $\left.4^{\circ} \mathrm{C}\right)$, a mitokondriumokat választottuk ki a csapadékba. Végezetül a felülúszó utolsó centrifugálásával $\left(48000 \mathrm{~g}, 1\right.$ óra, $\left.4^{\circ} \mathrm{C}\right)$ jutottunk hozzá a mikroszómális frakcióhoz (belső sejtmembránok és a plazmamembrán együttesen). A centrifugálásokat Hermle ZK 401-es típusú centrifugában végeztük, A8.24-es rotorral (Baba és mtsai., 2018). A kapott teljes sejtkivonatot és mikroszómális frakciót immunoblott analízissel vizsgáltuk tovább a fent már leírtak alapján. Az SDS-PAGE gélre minden mintából $25 \mu \mathrm{g}$ fehérjét vittünk fel. 


\subsection{Kromatin immunoprecipitáció}

4 gramm 6 napos E2FB-GFP-t, E2FA-GFP-t, és 35S::GFP-t expresszáló csíranövényből indultunk ki. A fehérjék és DNS közötti keresztkötések kialakításához 1\% (w/v) formaldehid oldatot adtunk, majd vákuum alatt infiltráltuk. A minták sejtmagját sejtmag izoláló pufferrel (0,25 M szaharóz, 15 mM PIPES - piperazin-N, N'-bisz (2-etánszulfonsav) pH 6,8, 5 mM MgCl 2 , $60 \mathrm{mM} \mathrm{KCl}, 15 \mathrm{mM} \mathrm{NaCl}, 1 \mathrm{mM} \mathrm{CaCl} 2,0,9 \%$ Triton X-100, $1 \mathrm{mM} \mathrm{PMSF}, 2 \mu \mathrm{g} \mathrm{ml}^{-1}$ pepsztatin A and $2 \mu \mathrm{g} \mathrm{ml}^{-1}$ aprotinin) nyertük ki, majd sejtmag lízis pufferrel feltártuk (50 mM 4-(2hidroxietil)-1-piperazinetánszulfonsav - HEPES pH 7,5, 150 mM NaCl, 1 mM EDTA, 1\% SDS, $0,1 \%$ nátrium deoxikolát, $1 \%$ Triton $\mathrm{X}-100,1 \mu \mathrm{g} \mathrm{ml}^{-1}$ pepsztatin A és $1 \mu \mathrm{g} \mathrm{ml}^{-1}$ aprotinin) és szonikálással 200-1000 bp-os darabokra tördeltük. A tisztított kromatinhoz anti-GFP poliklonális nyúl ellenanyagot (Invitrogen) adtunk, majd egy éjszakán keresztül folyamatos kevertetés mellett inkubáltuk a mintákat $4{ }^{\circ} \mathrm{C}$-on. Az ellenanyaggal jelölt mintákhoz lazacból származó sperma DNS/protein A agaróz gyöngyöket (Sigma) adtunk és két óráig $4^{\circ} \mathrm{C}$-on inkubáltuk. A gyöngyöket extrakciós pufferrel mostuk, majd eluáltuk a kromatint. A fehérje - kromatin keresztkötéseket megszüntettük, és izoláltuk a DNS-t. A tisztított DNS promóter régióit qPCR reakció során specifikus primerekkel vizsgáltuk. A DNS feldúsulásának kiszámítása során azt a technikát alkalmaztuk, hogy az ellenanyaggal készült immunoprecipitáció során kapott szignált elosztottuk az ellenanyag nélküli jellel (Saleh, Alvarez-Venegas és Avramova, 2008). A kromatin immunoprecipitáláshoz használt oligonukleotidokat a Függelék I. B táblázata tartalmazza.

\subsection{Reverz transzkripciós kvantitatív PCR (RT-qPCR)}

Az RNS kinyerése a növények leveléből történt, RNeasy Plant Mini Kit (Qiagen) segítségével. A cDNS-t $1 \mu \mathrm{g}$ RNS felhasználásával szintetizáltuk QuantiTect Reverse Transcription Kit-tel (Qiagen). A reverz transzkripciós kvantitatív PCR-t (RT-qPCR) SYBR Green festéssel BioScript PCR kit (Bioline) használatával végeztük, a gyártó utasításai szerint. A qPCR reakciókat 7900HT Fast Real-Time detekciós rendszerben végeztük. A mintákat hármasával futtattuk, és referencia génnek háztartási géneket használtunk, amelyek minden esetben az aktin és ubiquitin közül kerültek ki. Az eredmények analizálásához $2^{-\Delta \mathrm{CT}}$ vagy $2^{-\Delta \Delta \mathrm{CT}}$ metódust alkalmaztunk.

A mikroRNS meghatározása során az RNS-t Direct-zol RNA Kittel nyertük ki, majd a cDNS átírását $2 \mu \mathrm{g}$ RNS-ről végeztük MultiScribe ${ }^{\mathrm{TM}}$ reverz transzkriptáz segítségével. A qPCR TaqMan Small RNA Assays használatával történt. A reakciót Applied Biosystems 7900-HT Fast Real-Time detekciós rendszerrel végeztük.

A primerek szekvenciáját a Függelék I. A táblázatában tüntettük fel. Az összes reakciót háromszor ismételtük meg. 


\subsection{Termikus aszimmetrikus átfedő PCR (TAIL-PCR)}

A genomi DNS izolálása 2xCTAB (Cetil-Trimetil-Ammónium-Bromid) pufferrel (100 mM Tris$\mathrm{HCl} \mathrm{pH}$ 8.0, 1,4 M NaCl, $20 \mathrm{mM}$ EDTA, 2\% (w/v) CTAB, 2\% (w/v) PVP40 (polivinilpirrolidon), 0,2\% (w/v) $\beta$-mercaptoethanol) történt 2 hetes csíranövényekböl.

Három PCR reakciót végeztünk el egymást követően T-DNS-specifikus oligonukleotidokkal az egyik oldalról, és egy degenerált primerrel (AD1) a másik oldalról (12.ábra). Az első PCR során magas és alacsony specifitású lépések váltakoztak, így több aspecifikus termék keletkezett. A második és harmadik PCR a termék specifitásának növelésére szolgált (Liu és mtsai., 1995). Ezen PCR-ok során a primerek kötődési helye egyre közelebb helyezkedett el az AD1 primer kikötődési pontjához. Abban az esetben, ha a T-DNS a másik irányba inszertálódott volna be, vagy a degenerált primer az ellenkező irányba tapadt volna ki, a T-DNS másik oldalára specifikus oligonukleotidokat kellett volna alkalmaznunk az átfedő PCR-ok során. A T-DNS inszerciójának helyét a kapott termékből szekvenálással határoztuk meg. A TAIL-PCR-hoz használt primereket a Függelék I. C táblázata tartalmazza.

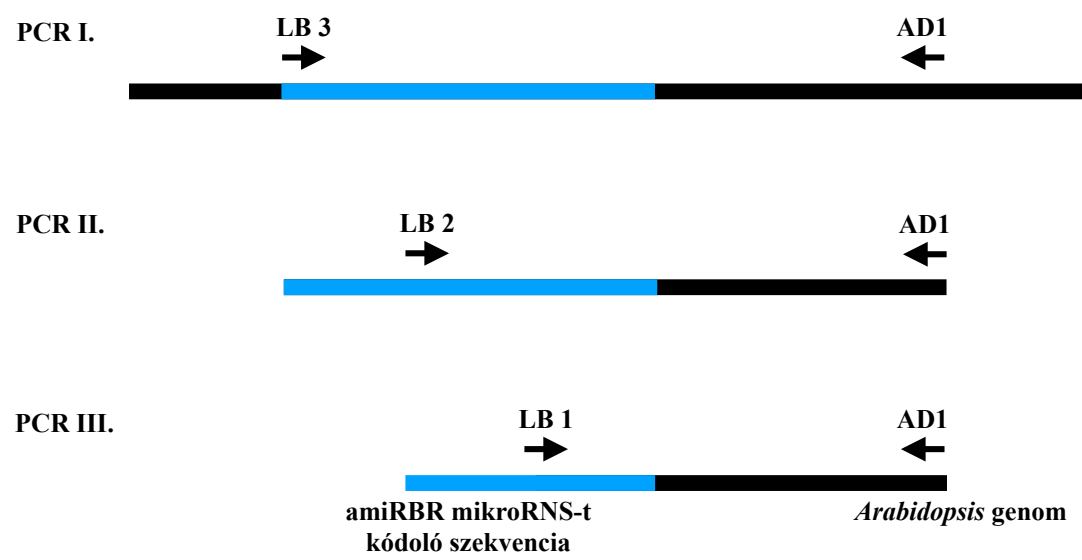

12. ábra. A TAIL-PCR sematikus ábrázolása.

A TAIL-PCR során három PCR reakció követte egymást. Az első terméket adó PCR-t (PCR I.) a mikroRNS bal oldali széléhez közeli primerrel (LB3) és a degenerált primerrel (AD1) végeztük, majd az itt kapott terméket használtuk a PCR II. templátjaként. Ezt követően a PCR II. során kapott termék lett a PCR III. templátja.

\subsection{Gyökér gravitációs teszt}

A növényeket függőleges lemezen növesztettük, majd a csírázástól számított 7. napon forgatási kísérleteknek vetettük alá őket. Képet készítettünk a gyökerek kiindulási helyzetéröl, ezután a lemezeket $90^{\circ}$-kal elforgattuk, majd 4 és 8 órát követően lefényképeztük a lemezeket. A kiindulási helyzetben megmértük a gyökerek görbülési fokát, amelyet a következő képlet alapján számoltunk ki (Wu és mtsai., 2015): 


$$
D C=\frac{L_{0}}{L}
$$

ahol $L_{0}=$ a legrövidebb távolság a gyökér kezdő és végpontja között

$L=$ a gyökér hossza

Az elforgatást követő 4. és 8. óra végén készített képeken a gyökereknek a vízszintessel bezárt szögét vizsgáltuk. Minél inkább követik a gyökerek a gravitációs ingert, annál közelebb van ez a szög a $90^{\circ}$-hoz. A képeket minden esetben az ImageJ program segítségével analizáltuk.

\subsection{Agroinfiltrált Nicotiana dohánylevél és transzgenikus Arabidopsis növények auxin efflux vizsgálata levél protoplaszt sejtekben}

A fecskendővel infiltrált, a célproteint/célproteineket tranziensen expresszáló Nicotiana és a célproteint stabilan kifejező Arabidopsis növényekből mezofill protoplasztot készítettünk (MCP - mesophyll cell protoplast buffer - 0,5 szorbitol oldatban (500 mM szorbitol, $1 \mathrm{mM} \mathrm{CaCl}_{2}, 10$ mM MES-KOH pH 5,6) 1\% (w/v) Celluláz Y-C, 0,1\% (w/v), pektináz Y-23 (Kyowa Chemical Products), 1\% (w/v) BSA - szarvasmarha szérum albumin). Az élő protoplasztokat Percoll MCP grádiensen szétválasztottuk. A mintákhoz $1 \mu \mathrm{l} 1 \mathrm{mCi} / \mathrm{ml}$ radioaktívan jelölt 7- ${ }^{14} \mathrm{C}$ benzoesavat és $1 \mu 11 \mathrm{mCi} / \mathrm{ml}$, szintén radioaktívan jelölt 5- ${ }^{3} \mathrm{H}$ indol-3-ecetsavat adtunk. A mintákat jégen tartva, fényen 15 percig inkubáltuk, majd a protoplasztok közül kimostuk a fel nem vett, felesleges radioaktívan jelölt hormonokat. Az auxin export vizsgálatát betain puffer $(400 \mathrm{mM}$ betain, 30 $\mathrm{mM} \mathrm{KCl}, 20 \mathrm{mM}$ HEPES, pH 7,2) hozzáadásával indítottuk el. A mintákat $25^{\circ} \mathrm{C}$-on inkubáltuk és 5 percenként mintát vettünk. A mintákban a folyamatot szilikonolaj Percoll grádiens segítségével állítottuk le. A mintákból $50 \mu$ l-t adtunk $3 \mathrm{ml}$ Ecoscint ${ }^{\mathrm{TM}} \mathrm{XR}$ szcintillációs koktélhoz (National Diagnostics). 24 óra ekvilibrációs periódust követően szcintillációs számlálóval vizsgáltuk a sugárzás erősségét (Noh, Murphy és Spalding, 2001; Geisler és mtsai., 2003).

\subsection{Student-teszt (t-próba)}

Az RT-qPCR során mért relatív expressziós szinteket, a kromatin immunoprecipitálás során kapott eredményeket és a növényi levelek sejtes analízise során kapott eredményeket (levélfelület, sejtszám, sejtek méret szerinti eloszlása, $60 \mu \mathrm{m}^{2}$-nél kisebb sejtek mennyisége) statisztikai vizsgálatnak, az ún. Student-tesztnek (t-próba) vetettük alá. A t-próba célja a mért mennyiségek közötti különbségek statisztikai szignifikanciájának meghatározása. Amennyiben az összehasonlítani kívánt adatsorok elemszáma megegyezett, egyenlő mintaszámú, kétszélü, azonos varianciájú Student-tesztet, ha pedig az adatsorok elemszáma különböző volt, eltérő mintaszámú, kétszélü, azonos varianciájú Student-tesztet alkalmaztunk. Azokban az esetekben, 
ahol komplementációt végeztünk, „a” és „b” jelölést alkalmaztunk, ahol „a” esetben a mutáns vonalat a WT-hoz viszonyítottuk, $\mathrm{p} \leq 0,05$ szignifikanciaszint mellett, míg „b” esetben a komplementált vonalakat a mutánsokhoz viszonyítottuk, $\mathrm{p} \leq 0,05$ szignifikanciaszint mellett. A relatív expressziós adatok és a kromatin immunoprecipitációs eredmények vizsgálata során nem különböztettünk meg eltérő szignifikanciaszinteket, hanem egységesen $\mathrm{p} \leq 0,05$ mellett vizsgálatuk a mért eredményeket. A szignifikáns eltéréseket csillaggal „*” jelöltük. A további esetekben a statisztikai ábrázolásban elfogadott jelöléséket alkalmaztuk, ahol minél alacsonyabb volt a ,p" érték, annál magasabb volt a szignifikancia szintje ${ }^{* * *}: \mathrm{p} \leq 0,001, * *: p \leq 0,01, *: p \leq 0,05$. 


\section{EREDMÉNYEK}

\subsection{Az Arabidopsis E2FB fehérje megjelenése a fejlődő levél epidermiszében}

Először arra voltunk kíváncsiak, hogy az E2FB fehérje mely levélsejtekben és mikor jelenik meg a levél fejlődése során. Ebből a célból létrehoztunk olyan transzgenikus Arabidopsis vonalakat, ahol az E2FB genomi DNS-t tartalmazó klónját fuzionáltuk a sárgán fluoreszkáló fehérje (YFP) egy erősebben fluoreszkáló, módosított változatával (vénusz YFP, röviden vYFP). A még jobb detektálás érdekében három tandem vYFP fehérjét fuzionáltunk az E2FB fehérje C-terminális végéhez. Ezt a fúziós konstrukciót az $E 2 F B$ saját promóterének az ellenőrzése alá helyeztük (pgE2FB-3xvYFP). Hasonló transzgenikus Arabidopsis vonalat hoztunk létre az E2FA-val is (pgE2FA-3xvYFP), valamint rendelkeztünk egy saját doménjében expresszálódó RBR-GFP transzgenikus növénnyel is (pgRBR-GFP; Magyar és mtsai., 2012). Fiatal csíranövények leveleit vizsgáltuk meg hat nappal, illetve tíz nappal a csírázást követően, konfokális lézermikroszkóp alatt. A hatnapos első levélpár még az osztódási fejlődési fázisban van, míg 10 nappal a csírázást követően már a megnyúlási folyamatok dominálnak. A leveleket propídium-jodiddal festettük meg a mikroszkópiás vizsgálatot megelőzően, és a levél abaxiális oldalának epidermális sejtjeit vizsgáltuk (13. ábra). Az E2FB fehérje a fiatal osztódó protodermális levélsejtek sejtmagjában és merisztemoidok sejtmagjában egyértelmüen detektálható volt, de meglepő módon a már teljesen differenciálódott epidermális sejtekben, a zárósejtekben, és a megnyúlt vaszkuláris sejtekben is kimutatható volt. Mindezek alapján feltételezhető, hogy az E2FB nemcsak a merisztemoidok osztódásának szabályozásában vesz részt, hanem a már differenciált levélsejtek müködésében is. Ezzel szemben az E2FA-3xvYFP-t csak az osztódó epidermális sejtek magjában tudtuk detektálni, míg más sejttípusokban nem, vagy csak diffúz, citoplazmatikus szignálként. Ez szintén jól jelzi, hogy az E2FA és az E2FB különböző folyamatok szabályozásában vehet részt. Az RBR-GFP szignált mind a merisztemoidokban, mind az osztódó és differenciálódó sejtekben megfigyelhettük, továbbá jelen volt az érett zárósejtekben is, de a szignál erősségéből adódóan feltehetően kisebb mennyiségben. 

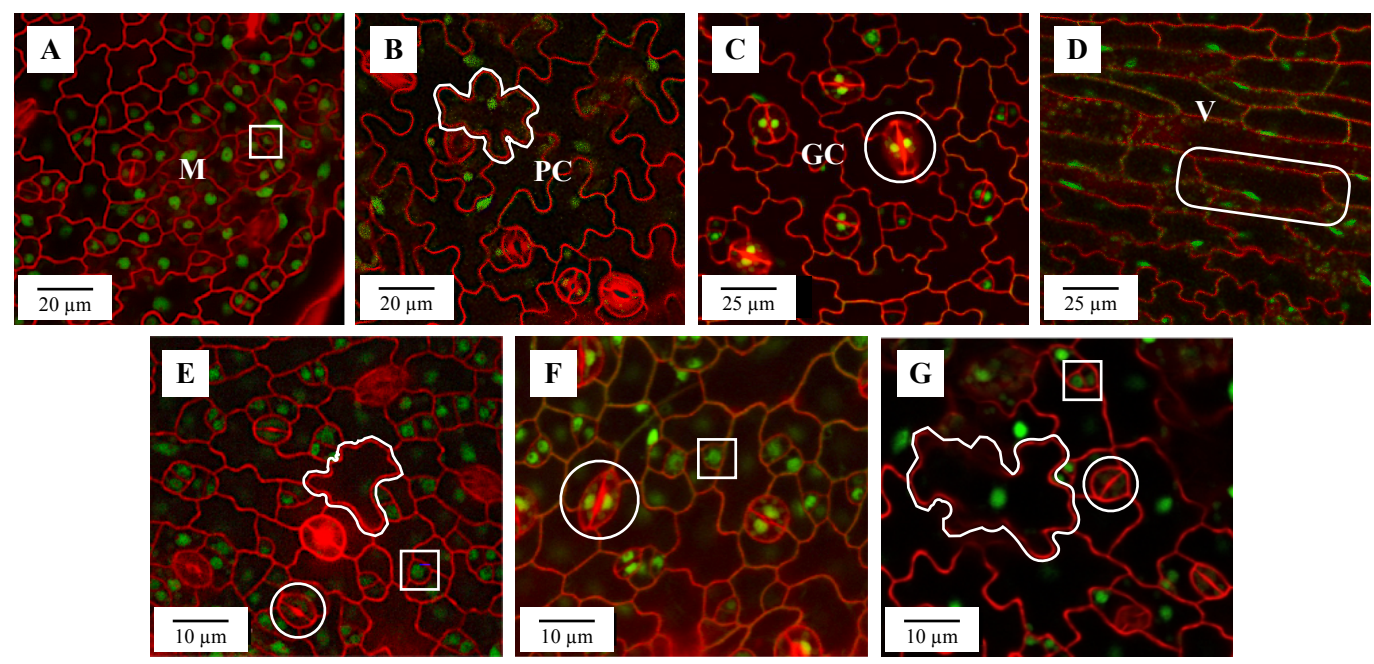

13. ábra. Az E2FA, E2FB és RBR fehérjék megjelenése különböző fejlődési állapotú és típusú levélsejtekben Reprezentatív konfokális lézermikroszkópos képek az első levélpár abaxiális oldaláról. A GFP és YFP jelek egyaránt zöld színủek, a sejtfal a propídium-jodid festés hatására piros. A négyzetek a merisztemoidokat (M), a körök a zárósejteket (GC), az amőboid formák a differenciálódott epidermális sejteket (PC), míg a lekerekített sarkú téglalapok a vaszkuláris sejteket $(\mathrm{V})$ jelölik. Az ábrák a következö vonalakról készültek a csírázást követő napokban (days after germination, röviden DAG): A) pgE2FB-3xvYFP (6 DAG), a B-D) pgE2FB-3xvYFP (10 DAG), E) pgE2FA-3xvYFP (8 DAG), F) pgE2FB-3xvYFP (8 DAG), G) pgRBR-GFP (8 DAG). Méretskála: $10 \mu \mathrm{m}, 20 \mu \mathrm{m}$ és $25 \mu \mathrm{m}$ (az ábrán jelezve).

\subsubsection{Az E2FB túltermeltetése gátolja a sejtosztódást és a levél növekedését}

Az E2FB további funkcionális jellemzéséhez olyan transzgenikus vonalakat használtunk fel, ahol az E2FB transzlációs változatát csak egyetlen, zölden fluoreszkáló GFP fehérjével fuzionáltuk (pgE2FB-GFP), annak érdekében, hogy csökkentsük a fúziós tag esetleges negatív hatását az E2FB funkciójára. Több mint 30 független transzgenikus vonalat azonosítottunk, köztük olyat, ahol az E2FB expressziója kiugróan magas (72-es vonal), közepes erősségü (93-as vonal), és kevésbé erős volt (61-es vonal). Megvizsgáltuk, hogy a kontrollhoz képest (14. ábra B), hogyan expresszál az E2FB ezeknek a kiválasztott vonalaknak a levelében (14. ábra A). Különbözö fejlődési időpontokban leveleket gyüjtöttünk be, és reverz transzkripciós kvantitatív PCR-ral (RT-qPCR) nyomon követtük az E2FB kifejeződését. A kontrollban az E2FB legerősebben a fiatal, még osztódó levélben fejeződik ki, de a későbbi fejlődési stádiumokban sem tünik el teljesen, csak csökken a szintje. Mindegyik transzgenikus vonalban a kontrollhoz nagyon hasonló $E 2 F B$ expressziós mintázatot láthattunk, csak jóval magasabb szinten. 
A

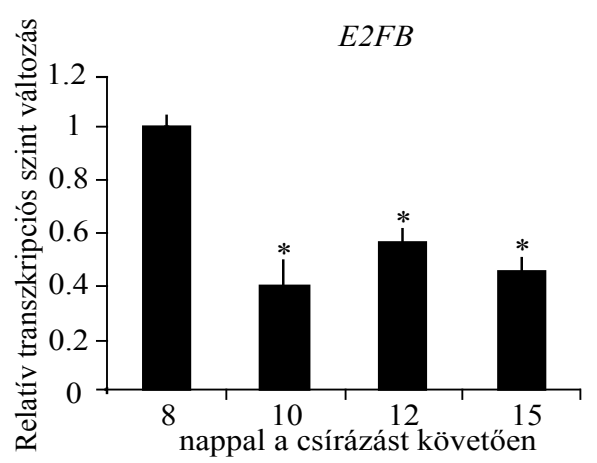

B

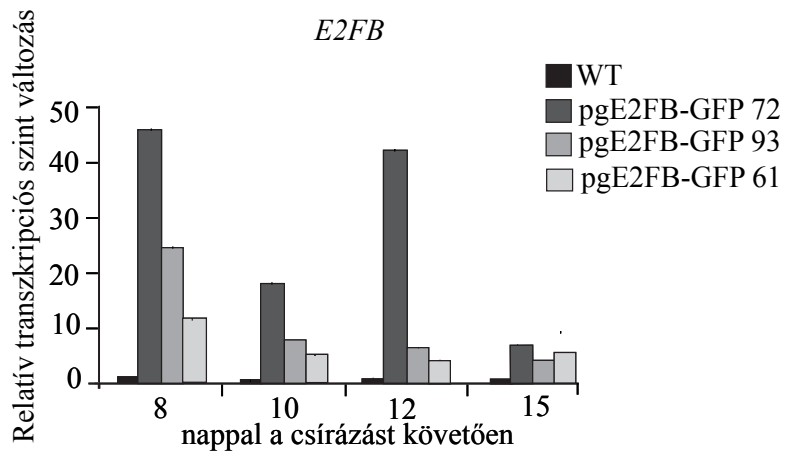

14. ábra. A saját expressziós doménjükben kifejeződő transzgenikus E2FB-GFP növényeket a kontrollhoz hasonló, de magasabb szintü E2FB expressziók jellemzik a fejlődő első levélpárban

Az E2FB relatív expressziós vizsgálata reverz transzkripciós kvantitatív PCR-ral (RT-qPCR) történt vad típusú és E2FB-GFP-túltermelő növények első levélpárjában, 8, 10, 12 és 15 nappal a csírázást követően. A) Az értékek három biológiai ismétlést mutatnak, ahol az E2FB expressziót WT növényeken vizsgáltuk (n=3) hibasávok: szórás, *:p $\leq 0,05$. Szignifikáns expressziós különbség figyelhető meg 10, 12 és 15 napnál a 8 napos expressziós szinthez viszonyítva, amelyet 1-nek vettünk. B) Három független pgE2FB-GFP vonal $(72,93$ és 61) és a vad típusú növények $E 2 F B$ expressziója az első levélpárban. A grafikon három technikai ismétlést ábrázol, a biológiai ismétlések nagymértékben hasonló mintázatot mutatnak. Az értékek szignifikáns expressziós növekedést mutatnak a vad típusú növényekhez viszonyítva, amelynek expressziós szintjeit 1-nek vettünk.

Megvizsgáltuk azt is, vajon az E2FB-GFP fehérje rendelkezik-e azokkal a tulajdonságokkal, amelyekkel az endogén E2FB is: képes-e kölcsönhatni az RBR és a DP fehérjékkel (DPA és DPB). Az erősen expresszáló 72-es vonal fejlődő leveleiből (első levélpár) történő immunoprecipitálással megállapítottuk, hogy az E2FB-GFP képes kötődni az RBR fehérjéhez, de annak csak a nem foszforilált formájához (15. ábra A). Az E2FB-GFP mindkét DP fehérjével képes dimerizálni (15. ábra B), és az E2FB-DP heterodimerek mennyisége jó korrelációt mutatott az E2FB fehérje mennyiségével (15. ábra C). Mindezek alapján feltételeztük, hogy az E2FBGFP fúziós fehérje funkcionális (és ezt a feltételezésünket a későbbi e2fb-2 mutáns komplementációs kísérletünk meg is erősítette - lásd 21. ábra).

Megfigyeltük, hogy az erösen túltermelö 72-es transzgenikus vonalban a növények mind talajon, mind pedig in vitro körülmények között kisebbre nőttek, mint a kontroll vad típusúak (16. ábra A-D). Kíváncsiak voltunk, miért kisebbek az E2FB-túltermelő vonalak levelei, ezért mikroszkóp alatt megvizsgáltuk a 72-es és a 93-as vonalak első levélpárját, és nyomon követtük a sejtszintü változásokat (epidermális összsejtszám, zárósejtek száma, sejtméret, zárósejt index, cirkularitási faktor). Két levélfejlődési időpontot választottunk ki a statisztikai analízishez: nyolc nappal a csírázást követően, amikor a levélsejtek még aktívan osztódnak (különösen a levél alapjánál), valamint egy négy nappal későbbi fejlődési állapotot, amikor a levélsejtek túlnyomó része már kilépett az osztódásból (Függelék II. táblázat). Propídium-jodid festett levelek abaxiális oldalán található epidermális sejtjeiről három különböző régióban készítettünk felvételeket a konfokális lézermikroszkóp alatt (a levél alapjáról, középső részéről, és csúcsáról). Ezeket összevetettük a hasonló korú vad típusú kontroll levelek sejtszintủ paramétereivel. Mindkét E2FB-túltermelő vonal a kontrollhoz képest kisebb levéllemez-felülettel rendelkezett, és minél erősebb volt az 
E2FB expressziója, annál kisebb lett a levél mérete. Meglepő módon az E2FB-túltermelő vonalak fiatal levelei lényegesen kevesebb sejttel rendelkeztek, mint a vad típusú kontroll hasonló korú levelei. A különbség a későbbi levélfejlődési állapotban ugyanakkor már nem nőtt tovább, sőt, némileg csökkent (16. ábra E, Függelék II. táblázat). A növények esetében a sejtszám csökkenésével párhuzamosan nőhet a sejtek mérete, ez az úgynevezett kompenzációs mechanizmus (Horiguchi és Tsukaya, 2011). Az E2FB-GFP expresszáló fiatal levelek bőrszövetében egyértelműen nagyobb méretủ sejteket detektáltunk, mint a kontrollban, de ez a trend az idősebb, 12 napos levélben megváltozott, és a kisebb méretü sejtek aránya nőtt meg a kontroll levelekhez képest (17. ábra D, Függelék II. táblázat).

A

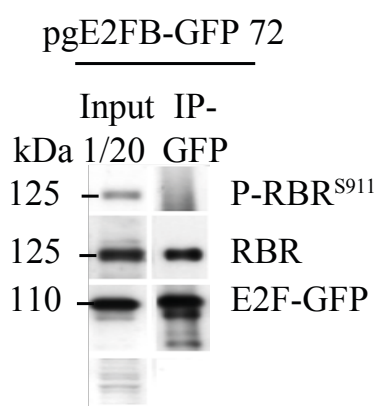

B

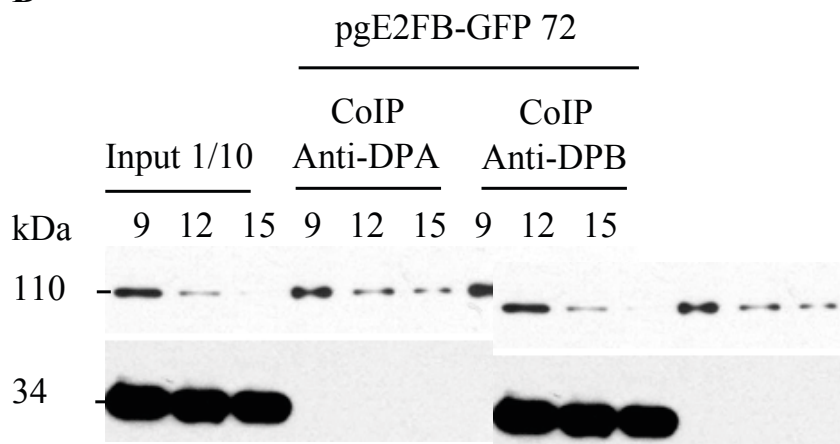

C

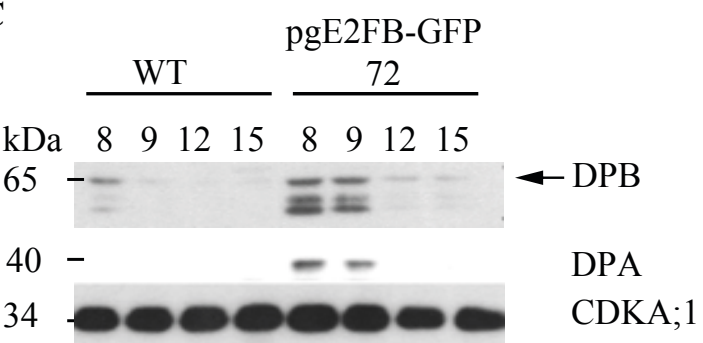

15. ábra. Az E2FB-GFP fúziós fehérje dimerizál a DPA és DPB fehérjékkel és komplexbe lép az RBR foszforilálatlan formájával

A) A fehérje kölcsönhatások vizsgálata koimmunoprecipitálás módszerével (coIP) történt anti-GFP ellenanyaggal a pgE2FB-GFP 72-es vonal első levélpárjából 8 nappal a csírázást követően. A kölcsönható fehérjék kimutatása western-blottal történt, amely során anti-P-RBR ${ }^{\text {Ser911 }}$, anti-RBR és anti-GFP ellenanyagokat használtunk. Az IP-hez használt fehérje mennyiségnek az 1/20 részét használtuk az input mintához. B) A pgE2FB-GFP 72-es vonal leveleiböl anti-DPA és anti-DPB ellenanyaggal történt az immunoprecipitálás, a jelzett időpontokban $(9,12$ és 15 nappal a csírázást követően). A precipitált fehérje komplexekben az E2FB-GFP fehérje detektálása anti-GFP ellenanyaggal történt. Az IP-hez használt fehérjemennyiség 1/10-ét használtuk az input mintához. A B és C ábrákon a CDKA;1 fehérjét használtunk kontrollként (egyenlő mennyiségek kimutatásához). C) Az első levélpárban (L1/2) vizsgáltuk a DPA és DPB fehérje szinteket 8, 9, 12 és 15 nappal a csírázás után a pgE2FB-GFP 72-es vonalban és a vad típusú kontroll Arabidopsis növényekben. A nyíl a DPB fehérjét mutatja. 

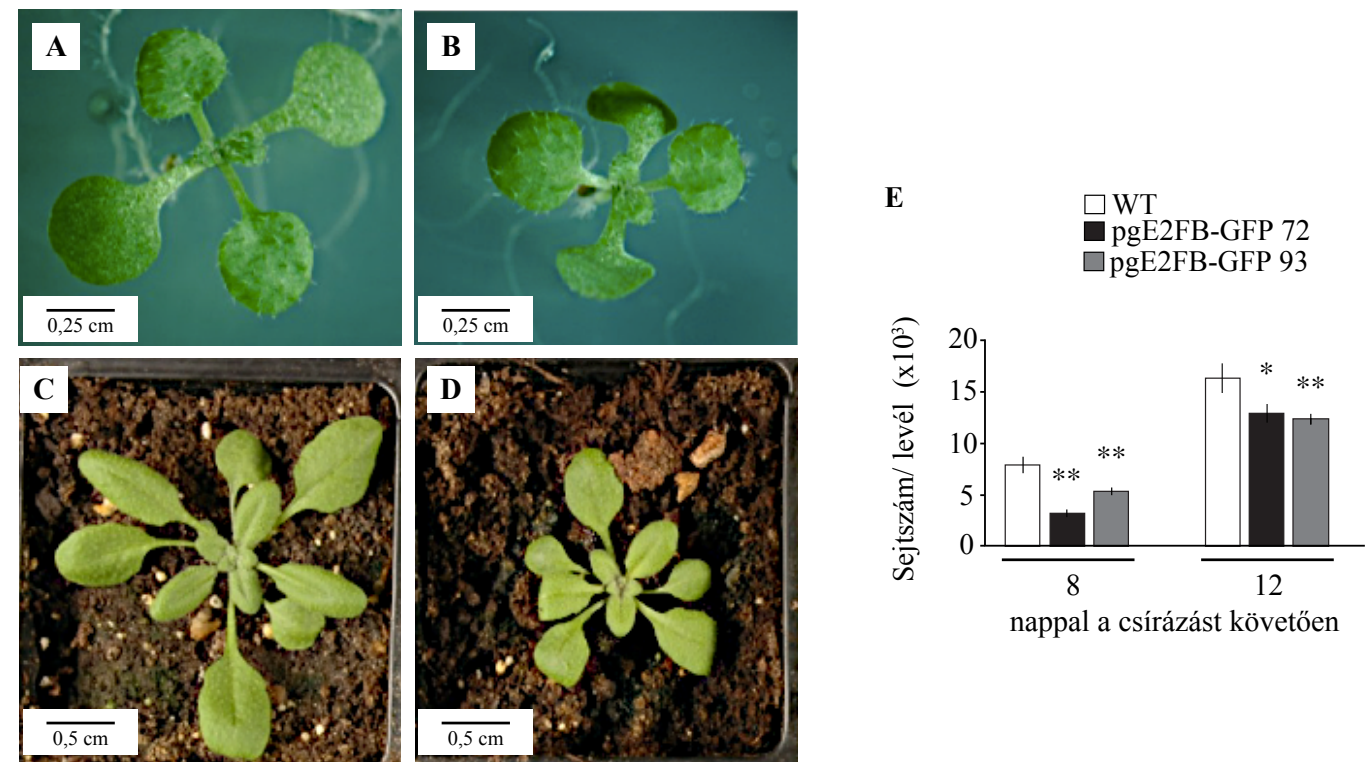

16. ábra. Az E2FB túltermeltetése gátolja a levél növekedését, és csökkenti a sejtszámot

A) Vad típusú és B) pgE2FB-GFP (72-es vonal) in vitro táptalajon nevelt növények 9 nappal a csírázás után. C) Vad típusú és D) pgE2FB-GFP (72-es vonal) üvegházi körülmények között talajon nevelt növények 20 nappal a csírázás után. Méretskála: $0,25 \mathrm{~cm}$ és $0,5 \mathrm{~cm}$ (az ábrán jelezve). E) A sejtszám alakulása a transzgenikus pgE2FB-GFP növények (72-es és 93-as vonalak) levél börszövetében a kontroll vad típusú növényekhez képest 8 és 12 nappal a csírázást követően ( $\mathrm{n}=3, \mathrm{~N}>600$, ahol „n” a biológiai ismétlések száma és „N” a vizsgált sejtek száma / minta). A szignifikanciát Student-teszttel határoztuk meg ," " esetben **: $\mathrm{p} \leq 0,01, *: \mathrm{p} \leq 0,05$, a vad típusú növényekhez viszonyítva.

Ismert, hogy a levélsejtek DNS-tartalma a levél növekedésével párhuzamosan növekedhet (Robinson és mtsai., 2018). Megmértük a transzgenikus és kontroll levelek sejtjeinek DNStartalmát áramlási citometriával: az oktoploid (8N) DNS-tartalmú levélsejtek először a tíznapos levelekben voltak detektálhatóak, de a transzgenikus levelekben és különösen a 72-es vonalban a kontrollhoz képest minden vizsgált időpontban kisebb számban voltak jelen (17. ábra A). Mindezek alapján a magas $E 2 F B$ expressziós szint gátolja az endoreduplikációt, ami alapján a fiatalabb levelekben megfigyelt nagyobb sejtméret nem a megnövekedett DNS tartalomnak tulajdonítható. A transzgenikus növények leveleiben, különösen a 72-es vonal esetében megfigyelhettük, hogy a már megnyúlt puzzle formájú bőrszöveti sejtekben új sejtfalak formálódtak (egyenes sejtfal, illetve sejtfalak megjelenése már érett, puzzle formájú sejtekben), amelyek arra engedtek következtetni, hogy ezek a sejtek visszaléptek az osztódásba (17. ábra BC). Ezeket a típusú osztódásokat extra osztódásnak neveztük el. Az extra osztódások száma a 72es vonal 12 napos levelében érte el a legmagasabb értéket (Függelék II. táblázat).

Mindezek alapján, az aktivátor E2FB túltermeltetése kevesebb sejtet és ennek köszönhetően kisebb leveleket eredményezett. Ez arra enged következtetni, hogy a megnövekedett E2FB expressziós szint gátolja a sejtosztódást, különösen a fiatal, még aktívan osztódó levélben. A legerősebben túltermelő 72-es vonal levelében ugyanakkor a sejtosztódásból már kilépett puzzle formájú levélsejtekben az osztódás reaktivációját is megfigyelhettük, és ez a jelenség a már megnyúló levélben volt a legmarkánsabb. Ez alapján az E2FB mind a sejtosztódásba lépést, mind pedig a kilépést szabályozza, de különböző levélfejlődési állapotokban. 

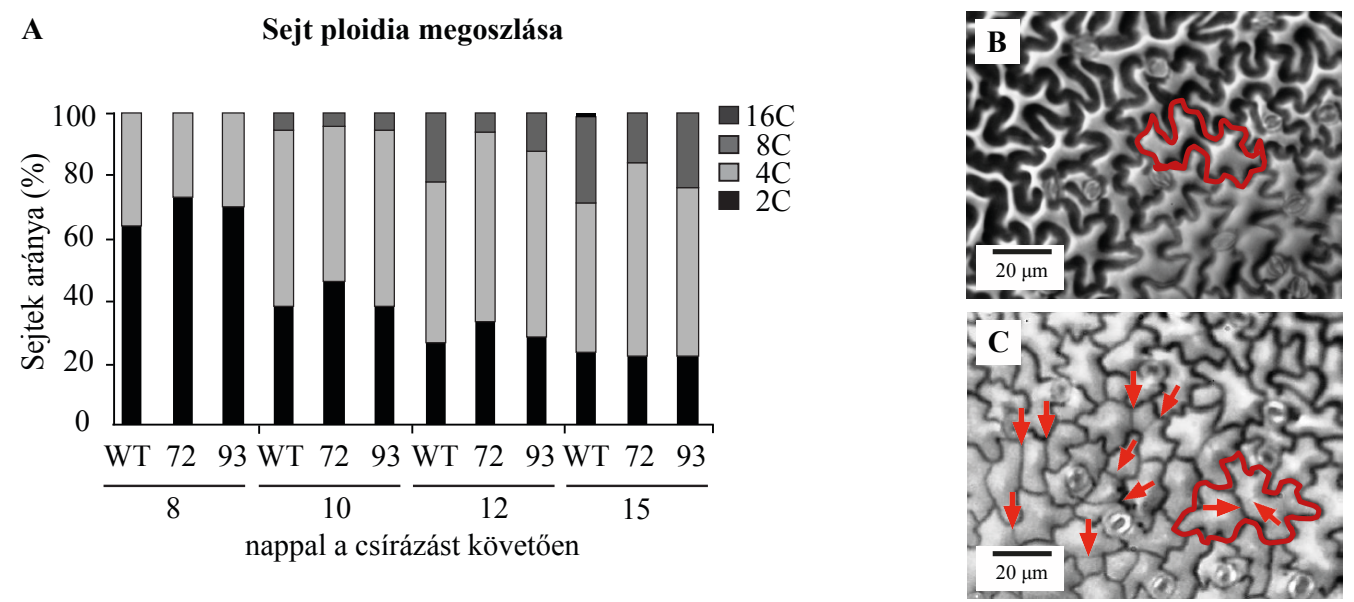

D

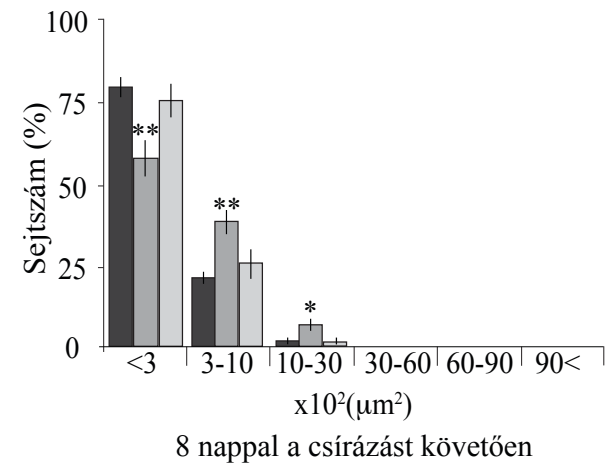

A sejtek méret szerinti megoszlása

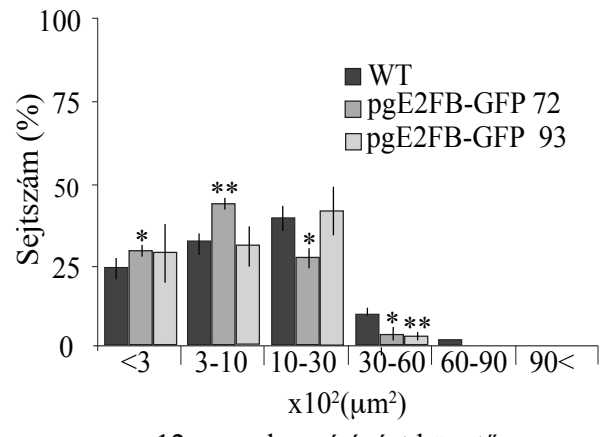

12 nappal a csírázást követően

17. ábra. A megemelt E2FB szint gátolja az endociklust, és extra osztódásokat indukál a már differenciálódó levél börszöveti sejtekben.

A) Vad típusú és E2FB-GFP-túltermelő növényi vonalak $(72,93)$ első levélpárjának DNS ploidia meghatározása áramlási citometriával. A levélminták begyüjtése 8,10, 12 és 15 napos korban történt. B) Reprezentatív képek vad típusú és C) pgE2FB-GFP (72-es vonal) növények első levélpárjának abaxiális epidermális sejtrétegéről 12 napos korban. A levél börszövet lenyomati képei differenciális interferencia kontraszt mikroszkópiával készültek. Puzzle formájú, differenciált börszöveti sejteket piros vonallal körberajzoltunk a vad típusú (B) és az E2FB-GFP-túltermelő leveleken (C). A piros nyilak az újonnan kialakult, egyenes sejtfalakat jelzik. D) A grafikon az epidermális sejtek méret szerinti eloszlását mutatja 8 (bal oldali) és 12 nappal a csírázást követően (jobb oldali grafikon). A méréseket az első levélpáron végeztük, 3 régióban (alap, közép- és csúcsi régió) n=3, N $>600$, ahol „n” a biológiai ismétlések száma és „N” a vizsgált sejtek száma / minta) **: $\mathrm{p} \leq 0,01, *: \mathrm{p} \leq 0,05$. Szignifikáns különbség figyelhető meg a vad típusú növények és a transzgenikus vonalak között 8 és 12 napos korban egyaránt.

\subsubsection{Az E2FB túltermeltetése gátolja a sejtciklus gének kikapcsolódását a levélfejlődés megnyúlási fázisában}

A következő lépésként arra voltunk kíváncsiak, hogy a megemelt $E 2 F B$ expresszió milyen molekuláris változásokat okoz a fejlődő első levélpárban. Ezért először megvizsgáltuk, hogyan változik meg a transzgenikus levelekben a sejtciklust szabályozó gének expressziója a kontrollhoz képest. Kiválasztottunk különböző sejtciklus fázisokban müködő sejtciklus szabályozó géneket, amelyekkel a teljes osztódási folyamatot le tudjuk fedni. A G1-S tranzíciós fázisból a CYCD3;1 és az RBR géneket, az S fázisból az ORIGIN RECOGNITION COMPLEX 2 (ORC2) gént, míg a G2-M fázisból a CYCLIN-DEPENDENT KINASE B1;1 (CDKB1;1) gént. Ezek a sejtciklus szabályozási gének egyben rendelkeznek E2F-kötő szekvenciával is. A kontroll- és transzgenikus növények első levélpárját négy különböző időpontban gyüjtöttük be, 
és a sejtciklus gének expresszióját reverz transzkripciós kvantitatív PCR-ral (RT-qPCR) követtük nyomon (18. ábra). Ahogyan az várható volt, az összes sejtciklus gén hasonló expressziós mintázatot mutatott a kontrollban. A gének a fiatal levelekben expresszáltak a legmagasabb szinten, és folyamatosan csökkenő tendenciát lehetett megfigyelni az idő elörehaladtával. Az S fázis-specifikus $O R C 2$ és a mitotikus $C D K B 1 ; 1$ gének a fiatal 8 napos transzgenikus levelekben a vad típushoz hasonló szintet mutattak, de a kontrolhoz képest továbbra is magasan expresszáltak a 10 és 12 napos transzgenikus levelekben. A CYCD3;1 és RBR gének expressziója már a fiatal, nyolc napos levélben is szignifikánsan magasabb volt, mint a kontrollban, és a többi sejtciklus génhez hasonlóan kifejeződésük szintje a kontrollhoz képest továbbra is magasabban maradt a későbbi levél stádiumokban is. Ezek az eredmények jó korrelációt mutatnak a 72-es vonal leveleiben megfigyelt extra osztódások gyakoriságával (Függelék II. táblázat). Ez arra enged következtetni, hogy az E2FB részt vesz a sejtciklus gének kikapcsolásában, feltehetően az RBR fehérjével komplexben. A kellően magas E2FB szint ezt a szabályozást elrontja, melynek következtében a sejtciklus gének hosszabb ideig aktívak maradnak, akkor, amikor már kikapcsolt állapotban kellene lenniük.
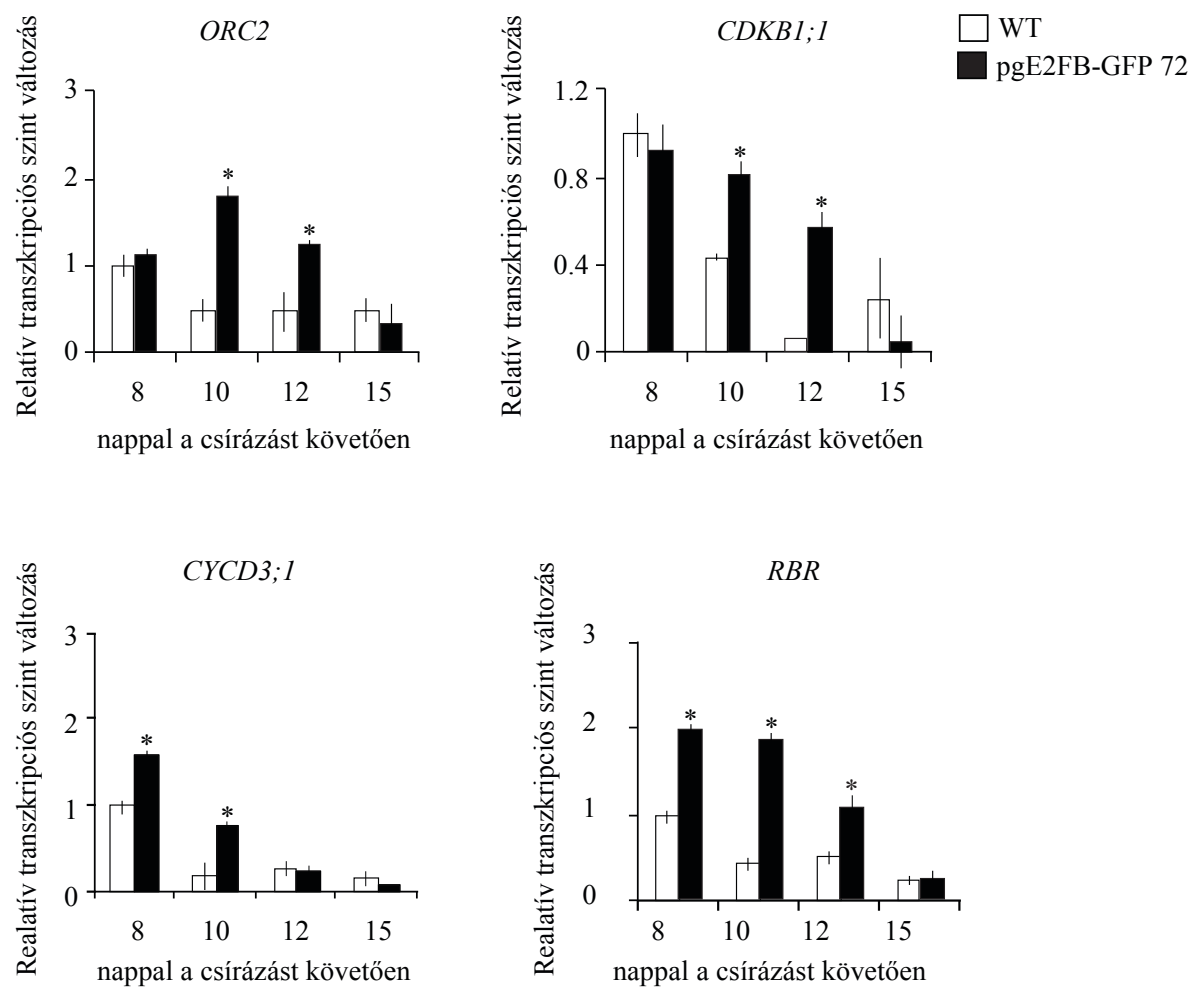

18. ábra. A saját expressziós doménjében megemelt E2FB szint késlelteti a sejtciklus gének kikapcsolódását

Az $O R C 2, C D K B 1 ; 1, C Y C D 3 ; 1$ és $R B R$ relatív expressziója a vad típusú növények és a pgE2FB-GFP 72es vonal első levélpárjában. A levélmintákat $8,10,12$ és 15 nappal a csírázást követően gyüjtöttük be. Az értékek az expressziós szint átlagát mutatják, amelyet a vad típusú növények 8 napos transzkripciós szintjéhez viszonyítottunk, amelyet egynek vettünk. A vonalak az oszlopok tetején a szórást jelölik, „*”-gal jelöltük a referenciaértékhez viszonyított, $p \leq 0,05$ szignifikanciaszint melletti szignifikáns eltérést. A szignifikancia meghatározása Student-teszttel történt a vad típusú és transzgenikus növények között a különböző időpontokban ( $\mathrm{n}=3$, ahol „n” a biológiai ismétlések száma). A primereket Függelék I. A táblázata tartalmazza. 
4.1.3. Az E2FB túltermeltetése fokozza az E2FB-RBR komplex felhalmozódását a fiatal, még osztódó levélben, amely feltehetően meggátolja és késlelteti a sejtek osztódásba lépését Az E2FB elsődleges szabályozója az RBR fehérje. Az RBR aktivitása a CDK-kon keresztül szabályozódik foszforiláció révén. A fő RBR-kináz a CDKA;1 (Nowack és mtsai., 2012). Korábban már kimutattuk, hogy az RBR foszforilált formája ( $\left.\mathrm{P}-\mathrm{RBR}^{\mathrm{Ser} 911}\right)$ nem képes kölcsönhatni az E2FA fehérjével, és most ugyanezt tapasztaltuk az E2FB-nél is (15. ábra, Magyar és mtsai., 2012). A CYCD3;1-túltermelő növényekben az RBR foszforilációja a konzerválódott 911-es poziciójú szerin aminosavon $\left(S^{911}\right)$ cukortól független körülmények között is bekövetkezett (Magyar és mtsai., 2012). Arra voltunk kíváncsiak, hogy a fejlődő első levélpárban a transzgenikus 72-es és 93-as vonalakban hogyan változik az RBR fehérje megjelenése és foszforiláltsága a kontrollhoz képest. A korábbi eredményekkel összhangban, az RBR fehérje mennyisége a kontroll növények esetében a legmagasabb szinten a fiatal, még osztódó levelekben volt detektálható és a későbbi levél stádiumokban a mennyiség lecsökkent (Borghi és mtsai., 2010; Magyar és mtsai., 2012). Az E2FB-túltermelő vonalakban az RBR fehérje megjelenése hasonló mintázatot mutatott, mint a kontrollban, de lényegesen magasabb szinten. Mindkét transzgenikus vonal levelében az RBR fehérje szintje követte a megváltozott magas E2FB szintet (19. ábra B). Az RBR foszforiláció nyomonkövetésére egy foszfo-specifikus állati ellenanyagot használtunk fel (anti-P-RB), amely az Arabidopsis RBR fehérjében a 911-es pozíciójú konzerválódott szerin foszforilációjának felel meg (Magyar és mtsai., 2012; Ábrahám és del Pozo, 2012; Wang és mtsai., 2014). A kontroll esetében az RBR a fiatal levelekben foszforilálódott a legerősebben, míg az azonos korú transzgenikus növényekben az RBR-hez hasonlóan szignifikánsan magasabb szinten volt detektálható (19. ábra A). A későbbi levélfejlődési időpontokban (10 és 12 napos levelek) a kontroll és a 93-as levélben az RBR foszforiláltsági állapota jelentősen visszaesett, míg a 72-es vonal leveleiben továbbra is magas RBR foszforilációs szintet detektáltunk. Ez az eredmény összhangban áll az itt megfigyelt extra osztódások gyakoriságával (Függelék II. táblázat). A különbség az RBR fehérje mennyiségében jóval nagyobb volt a kontroll és a transzgenikus levelek között, mint amit az $R B R$ transzkript szintjén láttunk (18. ábra). Ez arra engedett következtetni, hogy a fehérjemennyiségben látott változások hátterében nemcsak transzkripciós, hanem feltehetően traszlációs és/vagy poszttranszlációs események is szerepet játszanak. A következő kérdés, amire választ kerestünk, hogy a megemelkedett RBR fehérje szint vajon több E2FB-RBR komplexet is eredményez-e? Ennek érdekében az E2FB-GFP expresszáló vonalak leveléből anti-GFP ellenanyag segítségével E2FB fehérjét és a vele kölcsönható fehérje partnereit immunoprecipitáltuk, majd megvizsgáltuk, vajon az RBR fehérje jelen van-e ezekben az E2FB tartalmú komplexekben (19. ábra C). Mindkét transzgenikus növény esetében az abszolútértékben legtöbb RBR fehérjét az E2FB-vel komplexben a fiatal 9 napos levelekben találtuk, de a későbbi 12 és 15 napos levelekben is jelentős RBR kölcsönhatást figyelhettünk meg az E2FB-GFP fúziós fehérjével. Az E2FB tehát 
nemcsak megemeli az RBR fehérje szintjét, hanem komplexbe is lép vele. A megemelkedett E2FB-RBR komplex gátolhatja és ezzel késleltetheti az osztódásba lépést, különösen a fiatal levelekben, ahol a legnagyobb mennyiségben detektáltuk (19. ábra A-B). A 93-as és a 72-es levelekben a teljes fejlödési stádiumot figyelembe véve a precipitált RBR mennyisége egyik vizsgált időpontban sem tért el jelentősen egymástól (19. ábra C). Figyelembe véve ugyanakkor az E2FB fehérje- és a foszforilált RBR-szintek változásait a 12 és 15 napos levelekben, a 72-es vonalban feltételezhetően több szabad E2FB van, mint a 93-as vonalban (19. ábra). Az RBR-től megszabadult E2FB pedig reaktiválhatja az osztódásba lépést.

Összefoglalva tehát elmondhatjuk, hogy a saját expressziós doménjében megemelt E2FB szint hasonló mértékü RBR fehérje szintemelkedést generált, és ez lényegesen több E2FB-RBR represszor komplex kialakulásához vezetett. Ez a megsokszorozódott represszor komplex az, ami feltehetően gátolta a sejtosztódásba lépést a fiatal, még osztódó levelekben. Az E2FB-felesleg csak a későbbi fejlődési szakaszokban szabadul fel az RBR gátlása alól, amikor az RBR szintje és a komplex mennyisége is lecsökkent. Az E2FB szabad formája aktiválta a sejtosztódást a már differenciálódó levélsejtekben, ami arra enged következtetni, hogy az E2FB fontos szerepet játszik a nyugalmi állapot kialakításában, feltehetően az RBR-ral komplexben, azokban a sejtekben, amelyek már elkötelezték magukat a differenciálódás irányába.

A

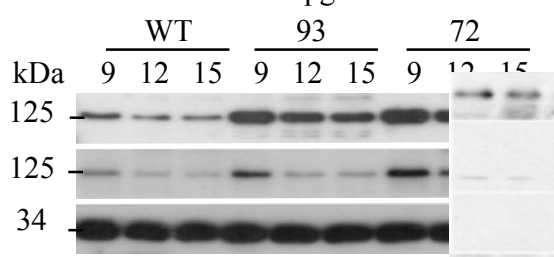

\section{RBR}

P-RBR ${ }^{\mathrm{S} 911}$

CDKA;1
B

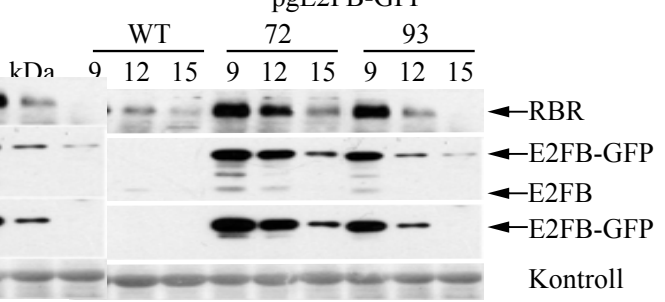

C

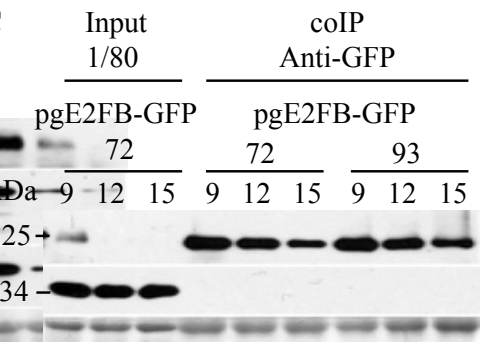

RBR

CDKA;1

Kontroll

19. ábra. Az RBR hatékonyan ellensúlyozza az E2FB fehérje szint emelkedését és komplexbe lép az E2FB-vel A) Az RBR és az RBR foszforilációja a konzervált 911-es szerin aminosavon anti-RBR és anti-P-RBR ${ }^{\mathrm{S} 911}$-specifikus ellenanyagok (anti-P-Rb807/811) felhasználásával. A western-blot minták a vad típusú, és a transzgenikus pgE2FBGFP 72-es és 93-as vonalak első levélpárjából készültek 9, 12 és 15 nappal a csírázást követően. Kontrollként a CDKA;1 fehérje mennyiségét mutattuk meg, amely a levél fejlődésének ezen szakaszaiban közel azonos mennyiségben van jelen. B) Az ábrán az RBR-t, az E2FB-t és az E2FB-GFP-t vizsgáltuk anti-RBR, anti-E2FB és anti-GFP ellenanyaggal immunoblot analízis során. A fehérjeminták a vad típusú és az E2FB-GFP fehérjét expresszáló 72-es és 93-as növényi vonalak első levélpárjából készültek 9, 12 és 15 nappal a csírázást követően. Coomassie-blue festékkel tettük láthatóvá a membránon található fehérjéket. C) Az E2FB-vel komplexet formáló RBR szint követésére koimmunoprecipitálást (coIP) végeztünk a transzgenikus pgE2FB-GFP 72-es és 93-as növényi vonalak leveleiből különböző időpontokban $(9,12,15$ nappal a csírázást követően) anti-GFP mágnes gyöngyök segítségével. A gél bal oldalán a 72-es vonalból származó input minta látható, ami az immunoprecipitáláshoz használt fehérje mennyiség 1/80ad része. Kontrollként membrán festést (Coomassie-blue) és CDKA;1 detekciót is alkalmaztunk. 


\subsubsection{Az E2FB funkció hiánya serkenti a merisztematikus levélsejtek osztódását a fejlődő levelekben}

Az eddigi eredményeink megmutatták, hogy mi történik a levél fejlődésében akkor, ha az aktivátor E2FB-t a saját expressziós doménjében termeltetjük túl. Kíváncsiak voltunk ennek az ellenkezőjére, mi történik a levél fejlődésével akkor, amikor a növény elveszíti az E2FBspecifikus funkcióit. Két T-DNS inszerciós mutánst használtunk fel erre a célra. Az e2fb-l-ben (SALK_103138) a T-DNS a dimerizációs domén mögé, míg az e2fb-2-ben (SALK_120959; Berckmans és mtsai., 2011a; Kobayashi és mtsai., 2015a; Kobayashi és mtsai., 2015b) a dimerizációs doménbe épült be (10. ábra). A T-DNS beépülése alapján feltételeztük, hogy az e2fb-1 egy funkcióvesztéses mutáns, ahol a csonka fehérje még bizonyos képességekkel továbbra is rendelkezik (DP dimerizáció és DNS-kötés), míg másokat elveszített (transzaktiváció és RBRkötés). Ezzel szemben az e2fb-2 feltehetóen egy nulla mutáns (minden E2F-specifikus képességet elveszítette), mivel a dimerizációs domén nélkül nem tud dimerizálni a DP fehérjékkel, és így a célszekvenciákhoz sem képes kötődni. Az inszerciós helyre tervezett E2FBspecifikus oligonukleotidokkal egyik mutánsban sem tudtuk kimutatni az $E 2 F B$ transzkript jelenlétét (20. ábra A-B). Ugyanakkor az inszerció elé tervezett E2FB-specifikus primerekkel mindkét esetben detektálni tudtuk az E2FB mRNS-et, mégpedig magasabb szinten, mint a kontrollban, ami arra engedett következtetni, hogy a csonka E2FB fehérje átíródhat (20. ábra C; Leviczky és mtsai., 2019). A teljes E2FB fehérjét egyik e2fb mutánsban sem tudtuk kimutatni a C-terminális-specifikus ellenanyag segítségével (20. ábra D; Kobayashi és mtsai., 2015).

Az e2fb mutáns növények makroszkópos megjelenésükben sem a korai, sem a késői stádiumukban nem különböztek lényegesen a vad típusú növényektől, az egyedüli különbség az e2fb-1 növények korai virágzása volt. Megvizsgáltuk azonban a két e2fb mutáns első levélpárját részletesebben is, a korábban már leírt módon (celluláris paraméterek, statisztikai analízis), és összehasonlítottuk a hasonló korú kontrollnövények leveleivel. A vizsgált fejlödési időpontokban (8 és 12 nappal a csírázás után) mindkét e2fb mutáns levele nagyobbnak bizonyult a kontrollnövények levelétől (Függelék II. táblázat). A sejtszintü analízis szerint az e2fb mutánsok leveleiben 8, és különösen 12 nappal a csírázást követően szignifikánsan több sejtet mutattunk ki a kontrollhoz képest (21. ábra A). Azért, hogy igazoljuk, hogy a levél fenotípusáért az E2FB hiánya a felelős, a pgE2FB-GFP konstrukciót bejuttattuk az e2fb-2 mutánsba. A transzgenikus növények közül két független traszformáns vonalat analizáltunk részletesebben. Mindkét esetben közel azonos szintü E2FB-GFP fehérjét detektáltunk az egy hetes csíranövényekben, amely jelentősen nagyobb mennyiségben volt jelen, mint az endogén E2FB a hasonló korú kontroll növényekben (21. ábra C). A komplementált növények és a kontrollnövények levélmérete 12 napnál már egyforma volt, és az e2fb-2 mutánsra jellemző magasabb sejtszám visszaesett a kontroll levél sejtszám értekei alá, ami a korábbi eredményekkel 
összhangban az ektopikus E2FB-GFP sejtosztódást gátló hatására utalhat (21. ábra A, Függelék II. táblázat).

A levélsejtek méretének analízise alapján megállapíthattuk, hogy az e2fb mutánsok levelében a kisméretü (60 $\mu \mathrm{m}^{2}$-nél kisebb, amely a merisztemoidok mérettartománya) sejtek száma lényegesen megnőtt a kontrollhoz képest (21. ábra B, Függelék II. táblázat). A kontroll levél epidermiszben 12 nappal a csírázást követően többnyire a kisméretű merisztemoid sejtek osztódnak, ezért feltételeztük, hogy az E2FB funkció hiányában a megnövekedett sejtszámért a levél merisztemoid sejtek többlet osztódása lehet a felelős. Ezt a feltételezésünket támasztotta alá, hogy az e2fb-2 komplementált, E2FB-GFP-t expresszáló vonalakban a kis sejtek a kontrollhoz hasonló gyakorisággal fordultak elő (21. ábra B, Függelék II. táblázat).

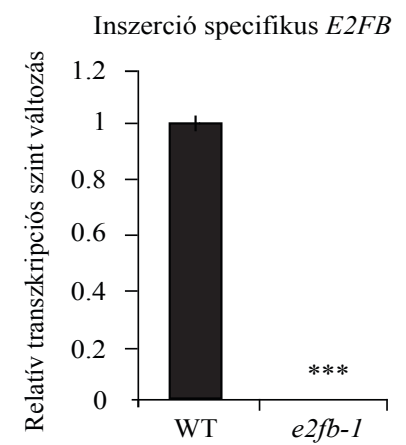

C

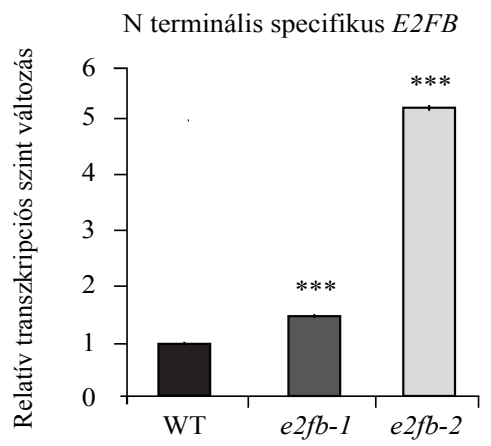

B

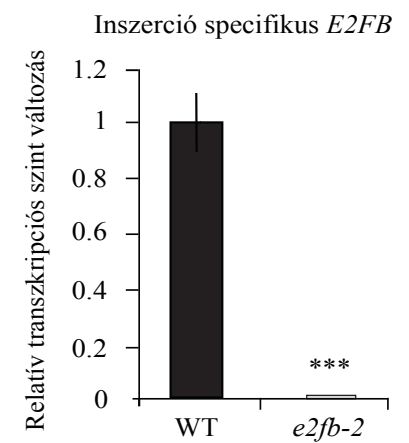

D

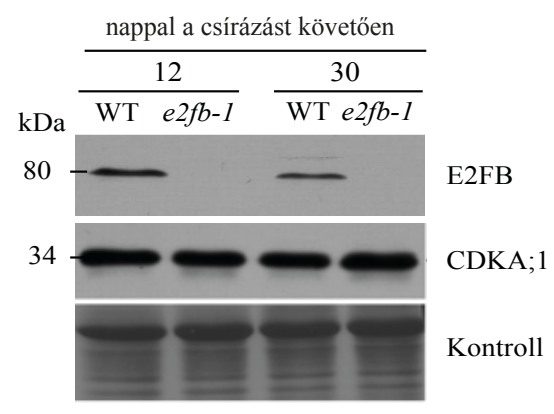

20. ábra. A T-DNS inszerciós e2fb mutánsok jellemzése

A-B) Az $E 2 F B$ inszert-specifikus (a T-DNS beépülési helyére tervezett) és C) az $E 2 F B N$ terminális-specifikus relatív transzkripciós szintjének vizsgálata RT-qPCR-ral vad típusú és $e 2 f b-1$ és $e 2 f b-2$ növényeken. Az eredmények az expressziós szint eltérését mutatják a vad típusú növényektöl, amelyek expressziós értéket egynek vettük $(\mathrm{n}=3$ biológiai ismétlés, az oszlopok az átlagot mutatják, vonalakkal az oszlopok tetején jelölve a szórást, ,"*”-gal jelöltük a szignifikanciát, ahol ***: $\mathrm{p} \leq 0,001$. Az oligonukleotidokat a Függelék I. A táblázata tartalmazza (Leviczky és mtsai., 2019). D) A $C$ terminálisra-specifikus anti-E2FB ellenanyag felismeri az E2FB fehérjét a vad típusú növényben, azonban az e2fb-1 mutánsban nem detektálható a fehérje, sem 12, sem 30 nappal a csírázást követően. A membránra felvitt fehérjéket Coommassie festéssel tettük láthatóvá. 
A

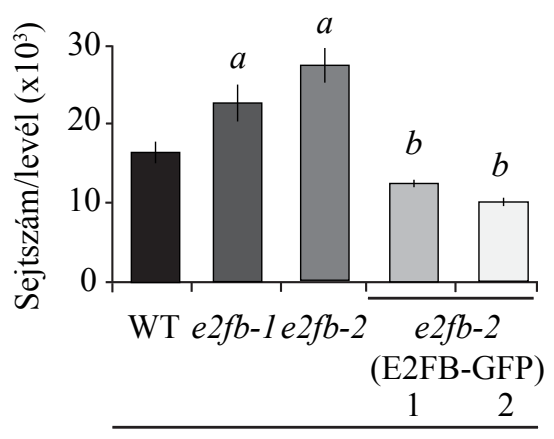

8 nappal a csírázást követően
B

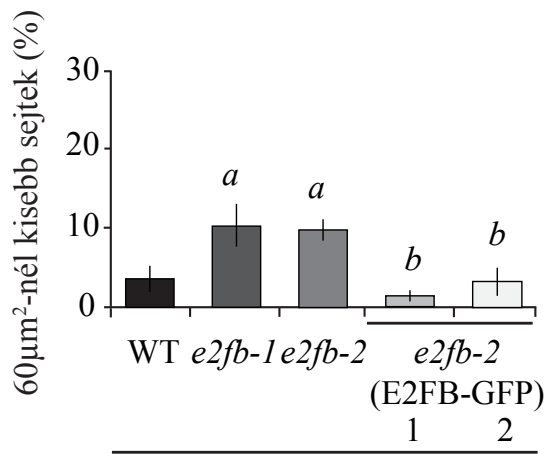

12 nappal a csírázást követően

C

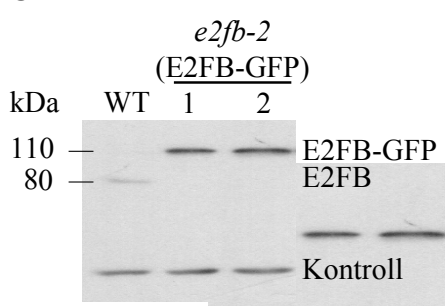

21. ábra. Az e2fb-1 és e2fb-2 mutánsok leveleiben megnőtt a kis méretü, merisztomid jellegü bőrszöveti sejtek száma

A) Az első levélpár levelenkénti összsejtszáma a 12 napos vad típusú, e2fb mutáns és az e2fb-2(E2FB-GFP) komplementált vonalakban.

B) A kisméretủ merisztemoid jellegü sejtek $\left(<60 \mu \mathrm{m}^{2}\right)$ százalékos aránya az összsejtszámhoz viszonyítva az első levélpárban 12 napos korban WT, e2fb-1,e2fb-2 és az e2fb-2(E2FB-GFP) komplementált vonalban ( $\mathrm{n}=3, \mathrm{~N}>600$, ahol „n” a biológiai ismétlések száma és „N” a vizsgált sejtek száma / minta). Az oszlopok az átlagot mutatják, a rajtuk elhelyezkedő vonalak a szórást jelölik. A szignifikanciát Student-teszttel határoztuk meg , $a$ ” esetben $\mathrm{p} \leq 0,05$, ahol az $e 2 f$ mutánsokat a WT-hoz viszonyítjuk míg , $b$ ” esetben $\mathrm{p} \leq 0,05$, ahol a komplementált vonalakat az $e 2 f$ mutánsokhoz viszonyítjuk. C) Endogén E2FB és a transzgenikus E2FB-GFP fehérjék C terminális-specifikus E2FB ellenanyaggal történő detektálása western-blottal 1 hetes kontroll, vad típusú és a komplementált e2fb-2(E2FB-GFP) vonalakból. Az antitesttel kölcsönható aspecifikus fehérje felviteli kontrollként szolgál.

A jelenlegi sejtciklus modellekben az E2FB-nek fontos aktivációs szerepet tulajdonítanak a sejtciklus gének bekapcsolásában. Megvizsgáltuk ezért, hogyan változik a sejtciklus gének kifejeződése a kontrollhoz képest az e2fb mutánsok leveleiben (első levélpár). A már korábban kiválasztott sejtciklus szabályozó gének mellett (CYCD3;1, RBR, ORC2, CDKB1;1), RT-qPCR módszerrel vizsgáltuk a MINICHROMOSOME MAINTENANCE COMPLEX COMPONENT 3 (MCM3), és a CIKLINA2;3 (CYCA2;3) kifejeződését is az első levélpár négy fejlődési időpontjában (22. ábra). A kontroll levelekben ezek a sejtciklus gének a fiatal levélben mutatták a legerősebb expressziót, és a későbbi időpontokban folyamatosan csökkent a kifejeződésük szintje (22. ábra). Az e2fb mutánsok leveleiben az összes általunk vizsgált sejtciklus génnek különböző mértékben ugyan, de csökkent az expressziója a legfiatalabb levélben, ahol a sejtosztódás még a legaktívabb volt. A legjelentősebb csökkenést a $C D K B 1 ; 1$ gén esetében figyelhettük meg; alacsony szinten ugyan, de kimutatható volt a CDKB1;1 mRNS. A későbbi levélfejlődési időpontokban azonban (10-12-15 napos levelekben) már nem találtunk szignifikáns különbséget a kontrollhoz képest. Ezek az eredmények megerősítik az E2FB 
transzkripciós aktivátor szerepét a sejtciklus gének teljes mértékü aktiválódásában, ugyanakkor megmutatták azt is, hogy az E2FB nem kizárólagos aktivátora a sejtciklus géneknek.
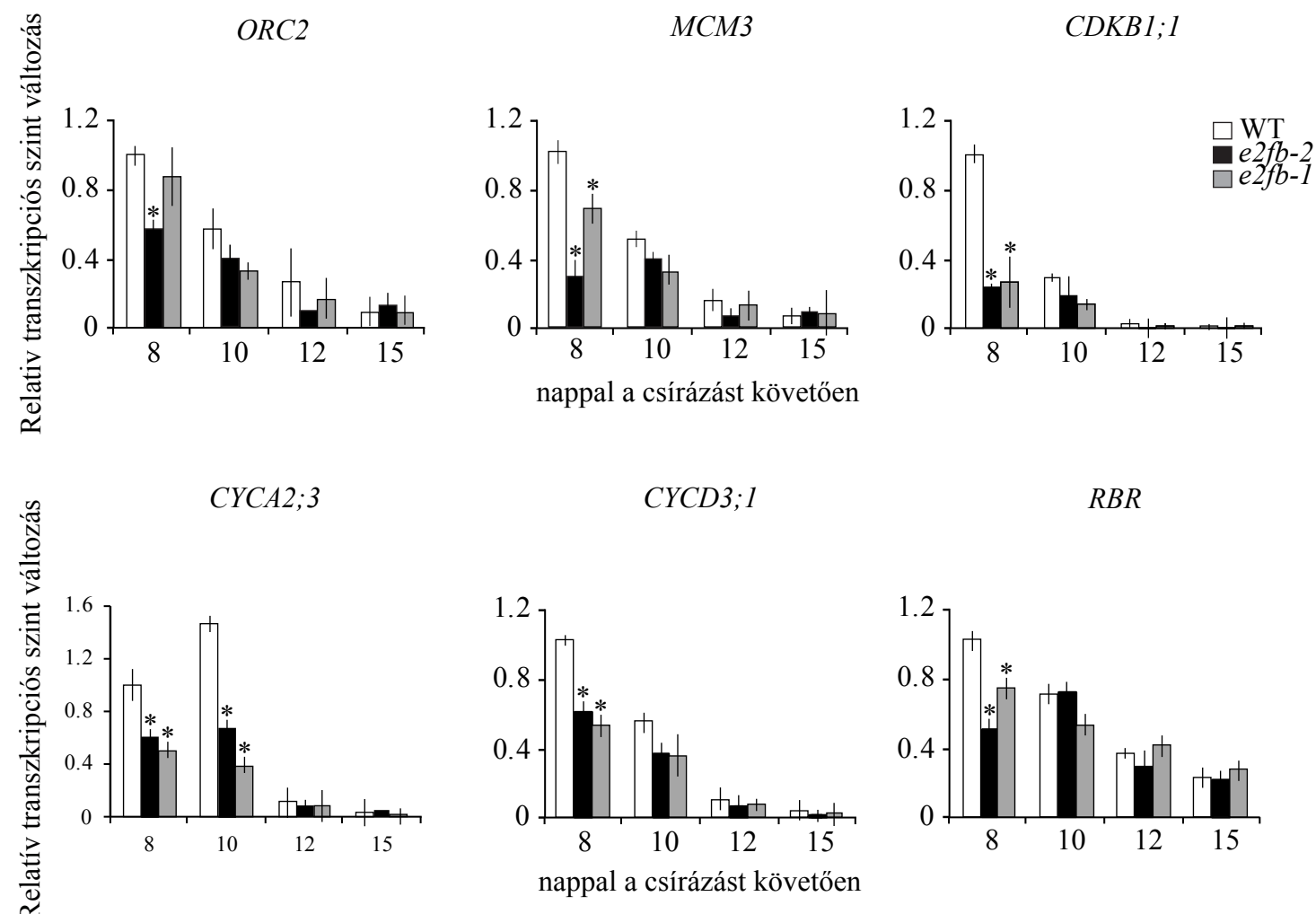

CYCD $3 ; 1$

$R B R$
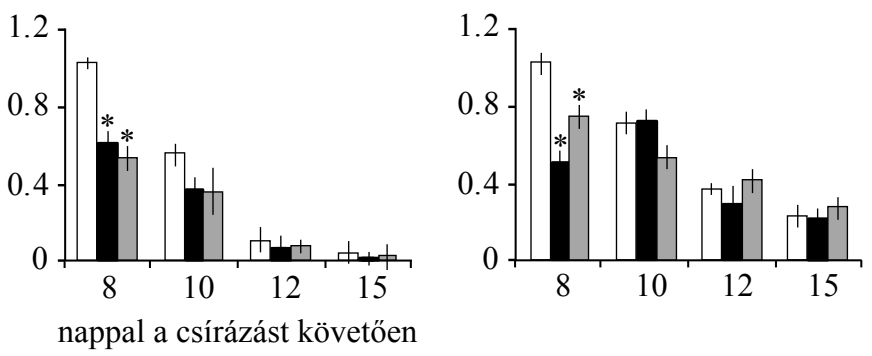

22. ábra. Az E2FB aktivátor funkció hiányában a fiatal osztódó levelekben csökkent a sejtciklus gének kifejeződése

Az ORC2, MCM3, CDKB1;1, CYCA2;3, CYCD3;1, és RBR gének relatív transzkripciós szintjének összehasonlítása, $8,10,12$ és 15 nappal a csírázást követően az e2fb-2,e2fb-1 és vad típusú növények első levélpárjában. Az értékek az expressziós szint átlagát mutatják, amelyet a vad típusú növények 8 napos transzkripciós szintjéhez viszonyítottunk, amelyet egynek vettünk ( $\mathrm{n}=3$, ahol „n” a biológiai ismétlések száma). A vonalak az oszlopok tetején a szórást jelölik, „*"-gal jelöltük a a referenciaértékhez viszonyított, $\mathrm{p} \leq 0,05$ szignifikanciaszint melletti szignifikáns eltérést. A szignifikancia meghatározása Student-teszttel történt a vad típusú és transzgenikus növények között a különbözö időpontokban. A primereket a Függelék I. A táblázata tartalmazza.

Kíváncsiak voltunk, vajon fehérje szinten is mutatnak-e különbséget a sejtciklus gének az e2fb2 mutáns levelekben a kontrollhoz képest. Specifikus ellenanyagok segítségével nyomon követtük az RBR, a CDKB1;1 fehérjék, valamint a P-RBR ${ }^{\mathrm{S} 911}$ szintjét a kontroll, az e2fb-2 mutáns, valamint a komplementált e2fb-2(pgE2FB-GFP) mutáns növények levelében (23. ábra) A western-blot eredmény alapján sem az RBR sem pedig a CDKB1;1 fehérje szintek nem csökkentek a fiatal mutáns levelekben a kontrollhoz képest (8 nappal a csírázást követően). A következő levélfejlődési időpontban (10 napos levél) azonban mindkét esetben jelentős redukciót láthattunk; az RBR fehérje teljes mértékben, míg a CDKB1;1 jelentősen lecsökkent a kontroll hasonló korú leveleihez képest. Ezek a változások E2FB-specifikusnak bizonyultak, mert az E2FB-GFP jelenlétében visszaállt a mutáns levélben a kontrollra jellemző RBR és CDKB1;1 fehérje mintázat. Legerősebb RBR foszforilációt a fiatal 8 napos kontroll levelekben detektálhattunk, ami teljesen eltűnt az e2fb-2 mutáns levelében. Az E2FB-GFP jelenléte az e2fb- 
2 mutánsban az RBR foszforilációt is helyre tudta állítani. Ezek az eredmények arra engednek következtetni, hogy az e2fb-2-ben megfigyelt transzkripciós változásokat bizonyos kompenzációs mechanizmusok képesek kijavítani.

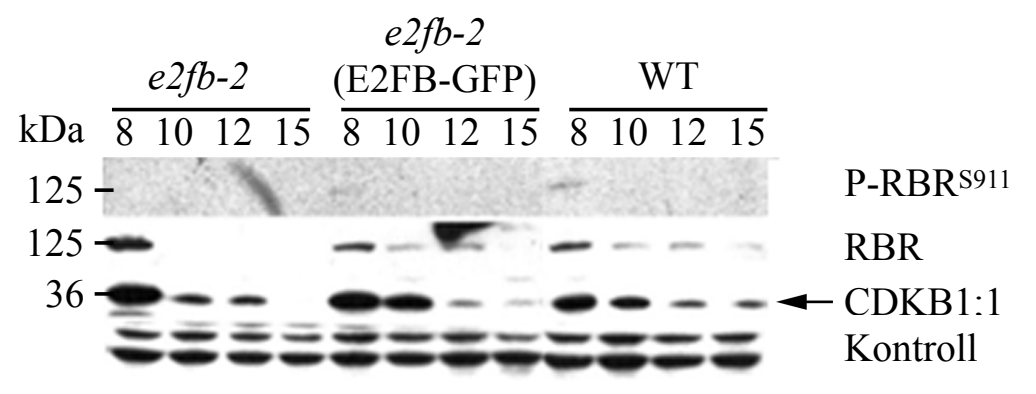

23. ábra. Az e2fb-2 mutáns fiatal osztódó levelében a transzkripciós változások fehérje szinten kompenzálódnak A western-blot analízishez a mintákat vad típusú $e 2 f b-2$ és komplementált $e 2 f b$-2(E2FB-GFP) növényi vonalak első levélpárjából különböző időpontokban gyüjtöttük (8, 10, 12 és 15 napos korban). Az RBR és az RBR foszforilációjának detektálása a konzervált 911 -es szerinen anti-RBR és anti-P-RBR ${ }^{\mathrm{S} 911}$-specifikus ellenanyag (antiP-Rb807/811) felhasználásával történt. A CDKB1;1-et anti-CDKB1;1 ellenanyaggal detektáltuk. A membránon található fehérjéket Coommassie festéssel tettük láthatóvá (kontroll minták).

\subsubsection{Az E2FA és E2FB képesek egymást kompenzálni, de eltérő molekuláris mechanizmuson keresztül}

A következő kérdés, amire a választ kerestük: vajon az Arabidopsis másik aktivátor E2F transzkripciós faktora, az E2FA szerepet játszik-e az e2fb-2 mutánsban megfigyelt kompenzációs mechanizmusban. Ennek érdekében először megvizsgáltuk, változik-e az E2FA és E2FB fehérjék szintje az e2fb-2 és e2fa-1 mutánsokban. Specifikus ellenanyagok segítségével összehasonlítottuk az e2f mutánsokban az E2FA és E2FB fehérjék szintjét a hasonló korú kontroll növényekben látottakkal (24. ábra A). Mindkét esetben pozitív hatást figyelhettünk meg: az E2FA funkció hiányában több E2FB, míg az E2FB mutánsban több E2FA fehérjét láthattunk, mint a kontroll növényekben. Kíváncsiak voltunk, vajon ez okoz-e változást az RBR fehérje mennyiségében és aktivitásában. Az e2fa-1 mutánsban több RBR fehérjét láttunk, de erősebb foszforiláltsági szinten, mint a kontrollban, míg az e2fb-2 mutánsban az RBR aktivitása nőtt meg. Tehát a két E2F fehérje egymással antagonisztikus viszonyban áll, és ellentétes hatást fejtenek ki az RBR funkciójára. Megvizsgáltuk, hogyan változik ez a kép a túltermelő pgE2FA-GFP (82es vonal) és a pgE2FB-GFP vonalakban (72-es vonal; Magyar és mtsai., 2012). Egy hetes csíranövényekben specifikus ellenanyagokkal western-blot módszerrel követtük nyomon az E2FA és E2FB fehérjéket (24. ábra B). Az eredmény megerősítette az e2f mutánsokban látottakat; a megemelt E2FA-GFP fehérje szint csökkentette az endogén E2FB fehérje szintjét, míg a magasabb E2FB-GFP fehérje szint jelenlétében az E2FA fehérjéből detektáltunk kevesebbet, mint a hasonló korú kontroll növényekben. Megvizsgáltuk, hogyan változik az RBRés a P-RBR-szint ezekben a transzgenikus növényekben (24. ábra C). Mindkét túltermelő vonalban az RBR szintje jelentősen megnőtt a kontrollhoz képest, de csak az E2FB-GFP jelenlétében láttunk erősebb RBR foszforiláltsági szintet. Ezek az eredmények megerősítették, 
hogy a két aktivátor E2F között megfigyelt fehérje szintủ kompenzáció az egymásra kölcsönösen kifejtett gátló mechanizmuson alapszik. A különböző E2F-ek ellentétes hatást fejtenek ki az RBR aktivitására; az E2FA aktiválja az RBR fehérjét (gátolja a foszforilációját), míg az E2FB stimulálja az RBR foszforilációját és így gátolja az aktivitását.

A

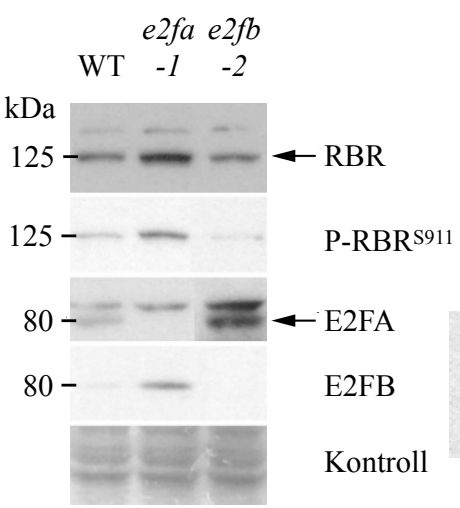

B

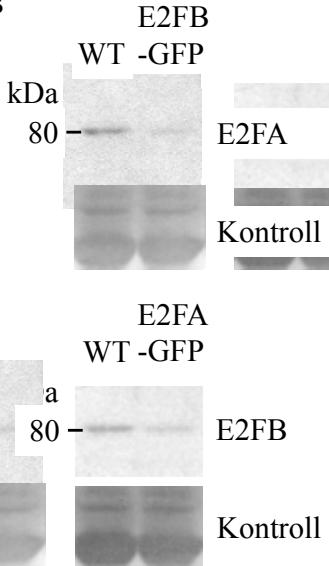

C

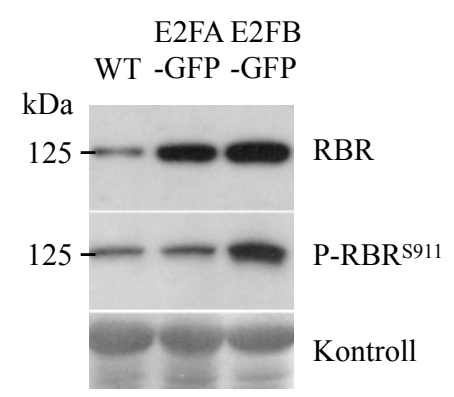

24. ábra. A két aktivátor E2F fehérjeszinten antagonisztikus viszonyban állnak egymással

A) A western-blot analízishez a mintákat 8 nappal a csírázást követően gyüjtöttük vad típusú, e2fa-1 és e2fb-2 növényekböl. Az RBR és az RBR foszforilációjának detektációja a konzervált 911-es szerinen anti-RBR és anti-P$\mathrm{RBR}^{\mathrm{S} 911}$-specifikus ellenanyag (anti-P-Rb807/811) felhasználásával történt. Az E2FA-t anti-E2FA, míg az E2FB-t anti-E2FB ellenanyaggal mutattuk ki. B-C) A minták elóállításához 8 napos vad típusú pgE2FA-GFP (82-es vonal) és pgE2FB-GFP (72-es vonal) csíranövényeket használtunk. Az E2FA-t anti-E2FA, az E2FB-t anti-E2FB, az RBR-t antiRBR és az RBR foszforilált formáját anti-P-RBR ${ }^{\text {S911 }}$-specifikus (anti-P-Rb807/811) ellenanyagok segítségével vizsgáltuk. A membránon található fehérjéket Coommassie festéssel tettük láthatóvá (kontroll minták).

A következő lépésként megvizsgáltuk, hogyan változik két $\mathrm{E} 2 \mathrm{~F}$ célgén, az $\mathrm{S}$ fázis-specifikus PROLIFERATING CELLULAR NUCLEAR ANTIGEN 1 (PCNA1) és a G2-M fázis-specifikus $C D K B 1 ; 1$ expressziója a rendelkezésünkre álló $e 2 f a(e 2 f a-1$ és $e 2 f a-2)$ és az $e 2 f b$ ( $e 2 f b-1$ és $e 2 f b$ 2) szimpla, és e2fab (e2fa-2/e2fb-1) dupla mutánsokban, valamint az e2fb-2(pgE2FA-GFP) és e2fb-2(pgE2FB-GFP) komplementált vonalakban. Hatnapos csíranövényekben RT-qPCR segítségével követtük nyomon ezeknek a géneknek a kifejeződését (25. ábra). A PCNA1 gén esetében a szimpla mutánsokban a vad típushoz képest nem láttunk lényeges expressziós különbséget (25. ábra A). Ezzel szemben a dupla e2fab mutánsban jelentősen visszaesett, míg a komplementált e2fb-2-es vonalainkban megemelkedett a PCNA1 transzkript mennyisége. Ez alapján az $\mathrm{S}$ fázis-specifikus $P C N A 1$ gén müködését a két $E 2 F$ aktivátor gén együtt szabályozza. A PCNA1 génnel szemben a $C D K B 1 ; 1$ expressziója az e2fa mutánsokban nem változott meg (e2fa-1) vagy inkább felerősödött ( $e 2 f a-2)$, míg az e2fb szimpla és az e2fab dupla mutánsokban jelentős és hasonló mértékủ redukciót lehetett megfigyelni. Ez alapján a $C D K B 1 ; 1$ kifejeződését az E2FB specifikusan szabályozza (25. ábra B). Az e2fb-2 mutánsban megfigyelt gyengébb $C D K B 1 ; 1$ expressziót helyre tudtuk azonban állítani mind az E2FB-GFP, mind pedig az E2FAGFP bevitelével, bár az E2FB jelenlétében magasabb szinten expresszálódott a $C D K B 1 ; 1$ a kontrollhoz és az E2FA-GFP vonalhoz képest. Ez az eredmény megerősítette, hogy az E2FA képes komplementálni az E2FB hiányát. 
A

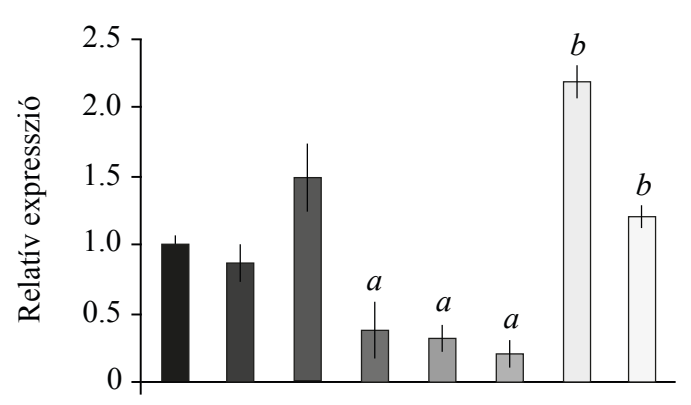

B

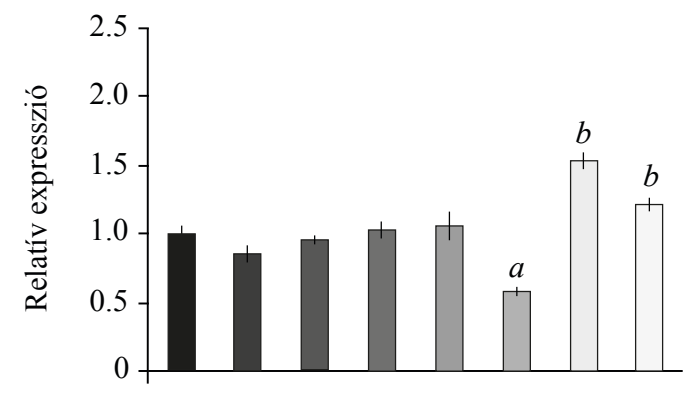

$\begin{array}{lll}\square \text { WT } & \square e 2 f b-1 & \square e 2 f b-2(\text { pgE2FB-GFP) } \\ \square e 2 f a-1 & \square e 2 f b-2 & \square e 2 f b-2(\text { pgE2FA-GFP) } \\ \square e 2 f a-2 & \square e 2 f a-2 / e 2 f b-1 & \end{array}$

25. ábra. Az E2FA képes az E2FB hiányában bekövetkezett csökkent CDKB1;1 expresszió helyreállítására

A A) $C D K B 1 ; 1$ és a B) $P C N A 1$ relatív expressziója vad típusú, e2fa-1, e2fa-2, e2fb-1, e2fb-2 szimpla, és e2fa-2/e2fb1 dupla mutánsokban, illetve olyan e2fb-2 növényekben, amelyekbe külön-külön visszavittük az E2FA és az E2FB GFP-vel fuzionáltatott verzióját (e2fb-2(pgE2FA-GFP) és e2fb-2(pgE2FA-GFP)). Az értékek az expressziós szint átlagát mutatják, amelyet a vad típusú növények 6 napos transzkripciós szintjéhez viszonyítottunk, amelyet egynek vettünk ( $\mathrm{n}=3$, ahol „n” a biológiai ismétlések száma). A vonalak az oszlopok tetején a szórást jelölik, , $a$ ” esetben $\mathrm{p} \leq 0,05$ mellett az expresszió szignifikánsan alacsonyabb a vad típusú növényekben mértnél, míg „ $b$ ” esetben $\mathrm{p} \leq 0,05$ mellett az expresszió szignifikánsan magasabb, mint az e2fb-2 mutánsban. A szignifikancia meghatározása Studentteszttel történt a vad típusú és transzgenikus növények között a különböző időpontokban. A primereket a Függelék I. A táblázata tartalmazza.

Hogy kiderítsük, képes-e átvenni az E2FA az e2fb mutánsban az E2FB szerepét, kromatin immunoprecipitálási eljárással (ChIP) megvizsgáltuk, vajon az E2FA képes-e kötődni a $C D K B 1 ; 1$ promóter régiójához az e2fb-2 mutánsban. Ismert, hogy a $C D K B 1 ; 1$ promóterében található egy E2F-kötő szekvencia 151 bp távolságra a transzlációs starthelytől (27. ábra; Boudolf és mtsai., 2014). A korábbi eredményeinkkel összhangban az E2FB feldúsulását figyelhettük meg a $C D K B 1 ; 1$ promoterén a pgE2FB-GFP expresszáló transzgenikus növényekben (26. ábra A). Ezzel szemben az E2FA-GFP fehérje sem a kontroll, sem pedig az e2fb-2 mutáns háttérben nem kötődött a $C D K B 1 ; 1$ gén promóteréhez. A PCNA1 promóterhez asszociálódva azonban mindkét E2F fehérjét ki tudtuk mutatni (26. ábra B). Mindezek alapján megállapíthatjuk, hogy az E2FA feltehetően alternatív úton képes az e2fb mutáns komplementációjára. 
A

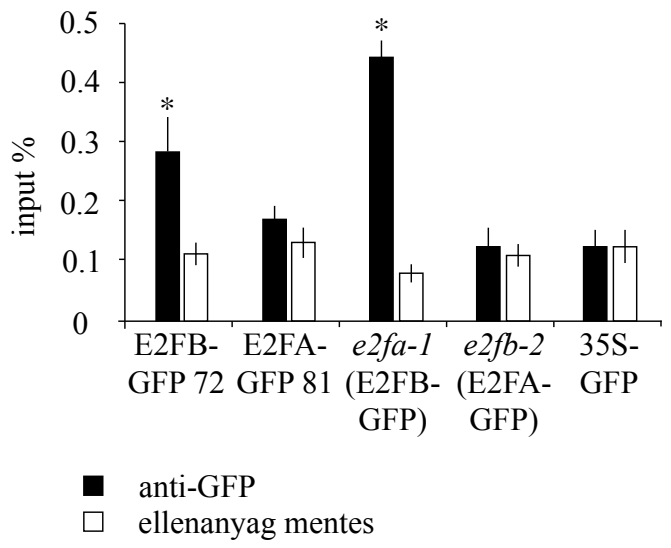

B

PCNA1 promóter (E2F kötő szekvencia)

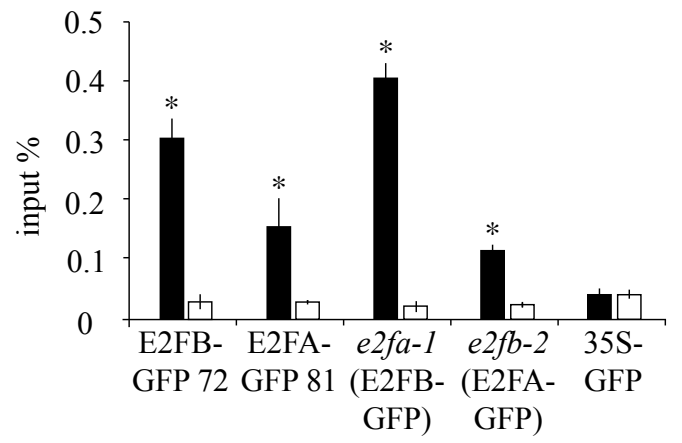

26. ábra. Az E2FA nem kötődik az E2FB-specifikus CDKB1;1 célgénhez az e2fb-2 mutánsban sem $\mathrm{Az}$ E2FA és E2FB fehérjék asszociációjának vizsgálata a A) $C D K B 1 ; 1$ és B) $P C N A 1$ promóterekhez kromatin immunoprecipitálással. A minták a pgE2FB-GFP 72-es, pgE2FA-GFP 81-es, pgE2FB-GFP-t expresszáló e2fa-1, pgE2FA-GFP-t expresszáló e2fb-2 és 35S:GFP csíranövényekből származtak. A vizsgálat poliklonális anti-nyúl GFP ellenanyag alkalmazásával történt. A qRT-PCR-rel felamplifikált régiók tartalmazzák a kanonikus E2F-kötő szekvenciát. „*” a konszenzus E2F fehérjekötőhelyek szignifikáns feldúsulását jelöli, $\mathrm{p} \leq 0,05$ szignifikanciaszint mellett.

\subsubsection{Az E2FB közvetlenül szabályozza a müködéséért felelős $R B R$ és $C Y C D 3 ; 1$ géneket}

Láthattuk, hogy az E2FB kifejeződédének fokozásával és csökkentésével az RBR és a CYCD3;1 kifejeződése hasonlóképpen változott meg. Mindez arra mutatott, hogy az E2FB közvetlenül szabályozhatja ezeket géneket. Az RBR és a $C Y C D 3 ; 1$, a $C D K B 1 ; 1$-hez hasonlóan tartalmaznak potenciális E2F-kötő szekvenciát a promóter regiójukban (az $R B R$ többet is, 27. ábra). Annak igazolására, hogy az E2FB az $R B R, C Y C D 3 ; 1$ és $C D K B 1 ; 1$ géneket közvetlenül képes szabályozni, kromatin immunoprecipitálási (ChIP) kísérleteket végeztünk az e2fb-2(E2FB-GFP) komplementált vonalon. Mindhárom gén promóterénél jelentős E2FB-GFP feldúsulást figyelhettünk meg, különösen az E2F-kötő helyeknél. Ezek az eredmények alátámasztják, hogy az E2FB közvetlenül szabályozza a müködéséért felelős $R B R$ és $C Y C D 3 ; 1$ gének kifejeződését. 
A

CYCD3;1 promóter

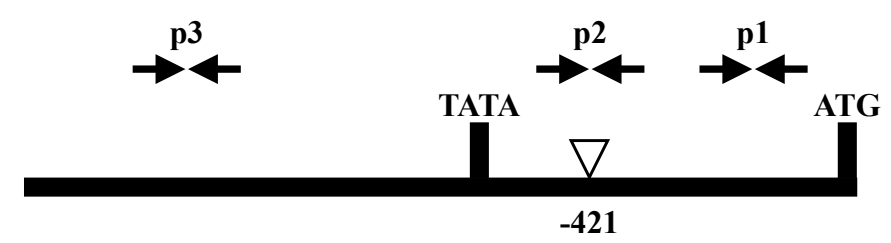

CDKB1;1 promóter
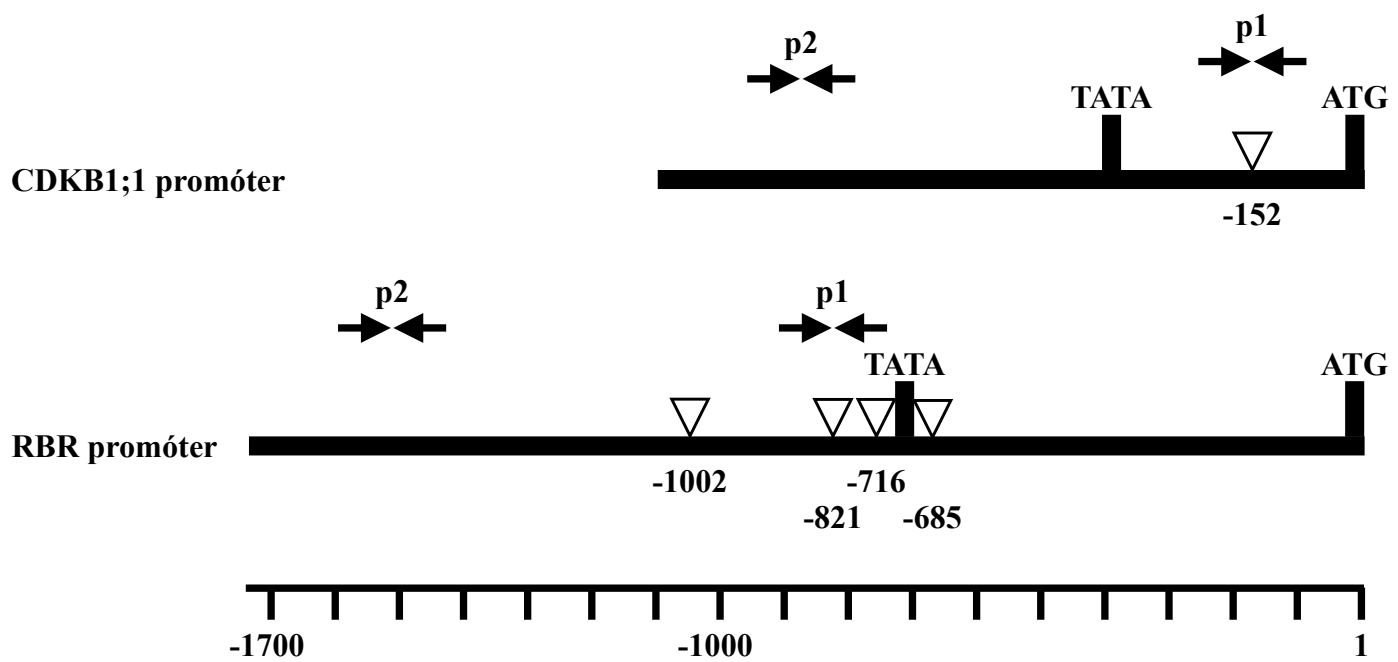

B

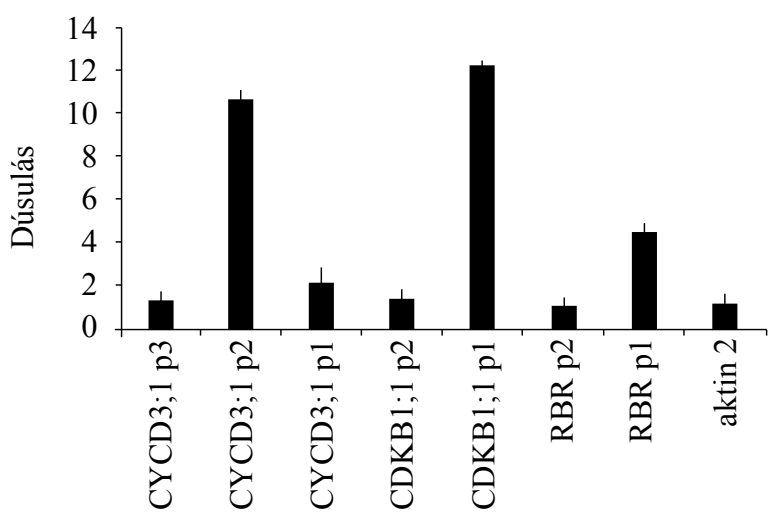

27. ábra. Az E2FB direkt módon kötődik a CYCD3;1, CDKB1;1 és az RBR promóteréhez

A) Sematikus ábra a $C Y C D 3 ; 1, C D K B 1 ; 1$ és az $R B R$ gének promóter régiójáról. A párosával elrendeződő nyilak (p1, p2, p3) a primerek pozícióját mutatják, amelyekkel a qPCR-t végeztük. A számok a kanonikus E2F-kötőhelyek (fehér, lefelé mutató nyílhegyek) START kodontól (ATG) lévő távolságot mutatják. Az oligonukleotidokat a Függelék I. B táblázata tartalmazza. B) Kromatin immunoprecipitáció az e2fb-2(E2FB-GFP) növényekből poliklonális anti-nyúl GFP ellenanyag segítségével. A grafikon a $C Y C D 3 ; 1, C D K B 1 ; 1$ és az RBR promóterek célrégióinak dúsulását mutatja.

\subsubsection{Az E2FB és a DPA együttes túltermeltetése nem vezet hiperproliferációhoz a fejlődő levelekben}

Az E2FB-röl korábban kimutattuk, hogy a DPA-val közösen túltermeltetve hiperaktiválta a sejtosztódást dohány sejtkultúrában (Bright Yellow 2, BY2; Magyar és mtsai., 2005). Emlősökben és emberben megfigyelték, hogy a legtöbb daganatos megbetegedés során az aktivátor E2F-ek expressziója túltermelődik, és feltehetően ez vezet a kontrollálatlan sejtosztódások kialakulásához (Chen, Tsai és Leone, 2009). Annak meghatározására, hogy az E2FB és DPA túltermeltetése az Arabidopsis növényekben is fokozza-e a sejtosztódást, megvizsgáltuk a p35S::HA-E2FB/DPA-túltermelő (a későbbiekben: E2FB/DPA ${ }^{\mathrm{OE}}$ ) 
transzgenikus növényeket, amelyekben mind az E2FB, mind a DPA magas szinten expresszálódott (29. ábra; De Veylder és mtsai., 2002; Magyar és mtsai., 2002; Magyar és mtsai., 2012; Horvath B, 2017). Az in vitro és a talajon nevelt transzgenikus E2FB/DPA ${ }^{\mathrm{OE}}$ növények szikleveleinek és valódi leveleinek mérete lényegesen kisebb volt, mint a hasonló korú kontroll, ezen felül a levelek szélei lefelé görbültek, amely egyenetlen sejtosztódási aktivitásra utalt (28. ábra A - B).

Szerettük volna megtudni, miért kisebbek a transzgenikus E2FB/DPA ${ }^{\mathrm{OE}}$ növények levelei. Az előzőekben már ismertetett kinematikai elemzést végeztük el az első levélpáron 8 és 12 nappal a csírázást követően és összevetettük a hasonló korú vad típusú kontroll levelek paramétereivel (Függelék II. táblázat). A 8 napos stádiumban a transzgenikus levelek epidermális sejtösszetételét nagyrészt a kisméretü és poligonális formájú sejtek uralták, de a sejtszám meglepő módon jóval a kontroll növények sejtszáma alatt maradt (28. ábra C-E és Függelék II. táblázat). Ez az eredmény arra engedett következtetni, hogy a transzgenikus levélben az epidermális sejtek a differenciálatlan, protodermális állapotban mintegy megrekedtek. Elképzelhetőnek tartottuk azt is, hogy az E2FB/DPA ${ }^{\mathrm{OE}}$ növények fejlődése lemarad a kontrollhoz képest; később csíráznak a magok, és/vagy később indulnak fejlődésnek a levél kezdemények. Azonban sem a transzgenikus magok csírázási képességében, sem pedig a levélfejlődésben nem láttunk lényeges különbséget a kontrollhoz képest, amely alátámasztotta volna ezt az elképzelésünket (nem bemutatott eredmények alapján). 12 nappal a csírázást követően az $\mathrm{E} 2 \mathrm{FB} / \mathrm{DPA}{ }^{\mathrm{OE}}$ növények levelében a sejtszám már a vad típusú növényekhez hasonló volt, ugyanakkor a sejtek még mindig lényegesen kisebbek voltak (28. ábra C-E és Függelék II. táblázat). Ez alapján az E2FB/DPA ${ }^{\mathrm{OE}}$ heterodimer túltermeltetése az Arabidopsis levélben gátolta a sejtek megnyúlását, akárcsak a dohánysejtekben.

A túltermeltetett $\mathrm{E} 2 \mathrm{FB} / \mathrm{DPA}{ }^{\mathrm{OE}}$ csíranövények levelében az E2FB expressziója az összes vizsgált időpontban (8-15 nappal a csírázást követően) lényegesen megnőtt a kontrollhoz képest (több mint ötvenszeresére, 29. ábra A). A hemagglutinin (HA)-taggelt E2FB fehérje szintje lényegesen magasabb volt a fiatal levélben, mint az endogén E2FB a kontrollban (29. ábra B). Azonban a transzkripcióval szemben a HA-E2FB fehérje szintje fokozatosan csökkent a transzgenikus levél fejlődése során. Még ennél is drasztikusabban változott a DPA fehérje szint, amit a 11. nap után már nem tudtunk kimutatni. Ez arra enged következtetni, hogy az E2FB a fejlődés során fehérje szinten is regulálódik. Az E2FB mitotikus target génje, a CDKB 1;1 fehérje szintje magasabb volt a fiatal, kilencnapos transzgenikus E2FB/DPA ${ }^{\mathrm{OE}}$ levelekben a kontrollhoz képest (29. ábra B). 

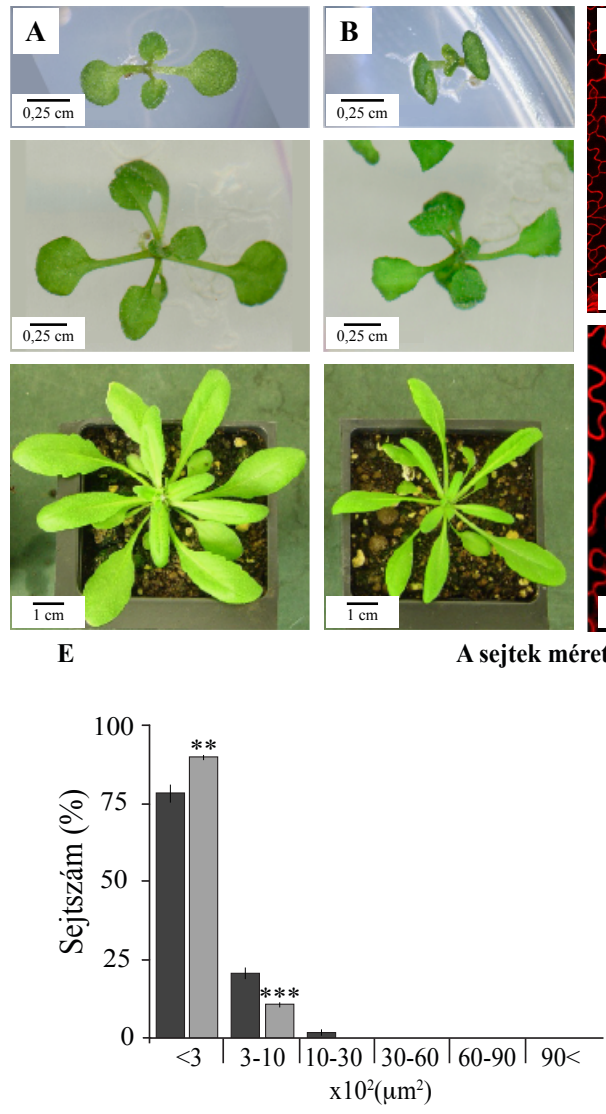

8 DAG
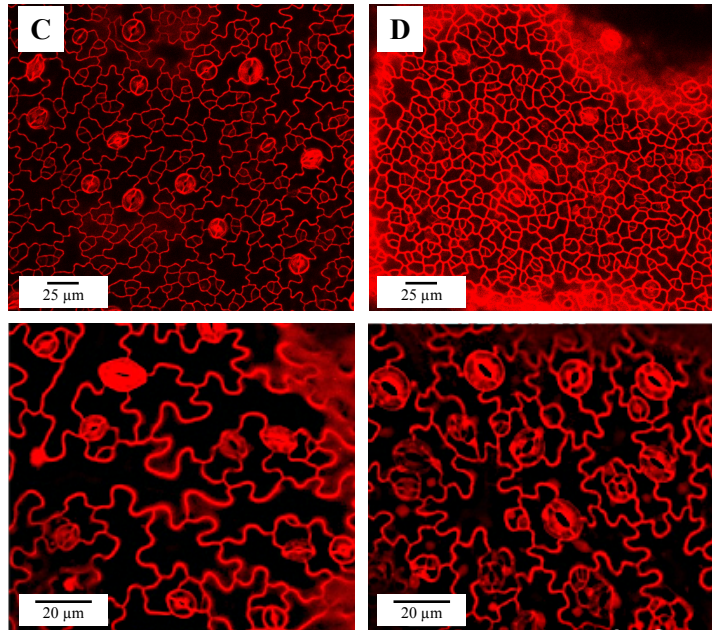

A sejtek méret szerinti megoszlása

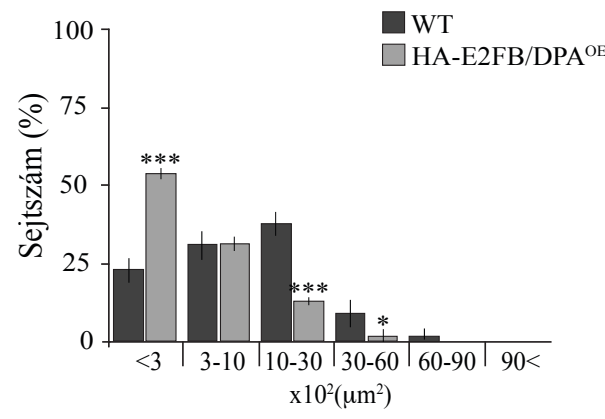

$12 \mathrm{DAG}$

28. ábra. Az E2FB és a DPA együttes túltermelése csökkenti a levélsejtek méretét

Reprezentatív képek a A) vad típusú és a B) p35S::HA-E2FB/DPA (E2FB/DPA ${ }^{\mathrm{OE}}$ ) in vitro és talajon nevelt növényekröl (fentröl lefelé 8, 12 és 21 napos korban). Mikroszkópos kép a C) vad típusú és D) E2FB/DPA ${ }^{\mathrm{OE}}$ növények epidermális sejtjeiröl a levél abaxiális oldalán (fentről lefelé 8 és 12 nappal a csírázást követően). A sejtek sejtfalát propídium-jodiddal festettük meg. E) A grafikon az epidermális sejtek eloszlását mutatja különböző mérettartományok szerint 8 (bal) és 12 napos korban (jobb oldali grafikon). A méréseket az első levélpáron végeztük, a levél 3 régiójában (levél alap, közép- és csúcsi régió) $\mathrm{n}=3, \mathrm{~N}>600$, ahol „n” a biológiai ismétlések száma és „N” a vizsgált sejtek száma / minta, ***: $\mathrm{p} \leq 0,001, * *: \mathrm{p} \leq 0,01, *: \mathrm{p} \leq 0,05$. Szignifikáns különbség figyelhető meg a vad típusú növények és a transzgenikus vonalak között 8 és 12 napos korban egyaránt.
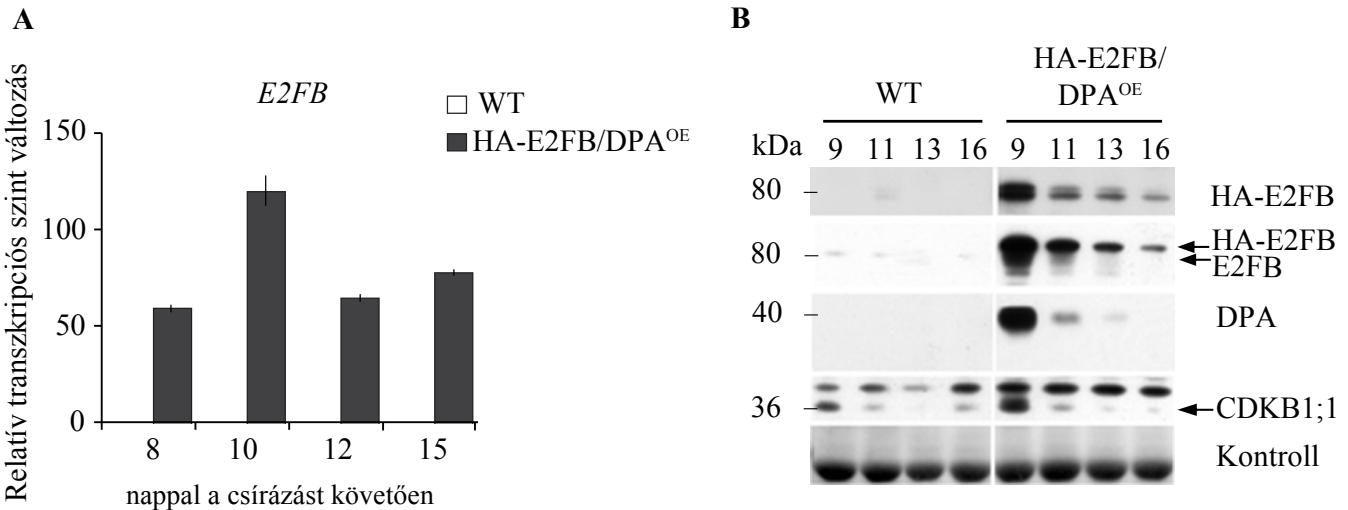

29. ábra. A p35S::HA-E2FB/DPA ${ }^{\text {OE }}$ transzgenikus növény levelében a HA-E2FB fehérje szinten szabályozódhat A) $\mathrm{Az} E 2 F B$ relatív expressziós szintjének összehasonlítása a fejlődő első levélpárban $\mathrm{E} 2 \mathrm{FB} / \mathrm{DP}{ }^{\mathrm{OE}}$ és vad típusú növényekben $8,10,12$ és 15 nappal a csírázást követően, ahol a vad típusban az expresszió szintjét egynek vettük (n = 3, ahol „n” a biológiai ismétlések száma). A primereket a Függelék I. A táblázata tartalmazza. B) A HA-epitóppal jelölt E2FB, az endogén E2FB, a DPA és a CDKB1;1 fehérjék levélfejlődés szerinti vizsgálata western-blot analízissel. A minták az első levélpárból származnak 9, 11, 13 és 16 nappal a csírázást követően vad típusú és p35S::HA$\mathrm{E} 2 \mathrm{FB} / \mathrm{DPA}{ }^{\mathrm{OE}}$ növényekből. A vizsgálat során anti-HA, anti-E2FB, anti-DPA, és anti-CDKB1;1 ellenanyagokat használtunk. A membránon a fehérjéket Coomassie-blue festéssel tettük láthatóvá (kontroll). 
Mivel az E2FB/DPA ${ }^{\mathrm{OE}}$ vonal első levélpárjában kevesebb sejtet figyelhetünk meg 8 nappal a csírázást követően, kíváncsiak voltunk arra, hogyan változott az E2F célgének expressziója (30. ábra). A már korábban is vizsgált sejtciklus géneket választottuk ki erre a célra ( $R B R, C Y C D 3 ; 1$, ORC2, MCM3, CDKB1;1) és RT-qPCR módszerével követtük nyomon őket a fejlődő első levélpárban. Mindegyik gén szignifikánsan magasabb szinten expresszált az E2FB/DPA ${ }^{\mathrm{OE}}$ vonalban, mint a vad típusú azonos korú növények leveleiben (30. ábra). Az expressziós szintek az idő elörehaladtával a túltermelő növények leveleiben csökkenő tendenciát mutattak, ami korrelációban állhat a HA-E2FB és DPA fehérjék szintjének csökkenésével. Két másik sejtciklus gént is teszteltünk, nevezetesen a CDK inhibitor KIP-RELATED PROTEIN 4-et (KRP4) és a CIKLINA3;1-et $(C Y C A 3 ; 1)$, ahol lényegesen kisebb aktivációt láthattunk az E2FB/DPA ${ }^{\mathrm{OE}}$ vonalban, mint az előző csoportnál.

Immunoblottal megvizsgáltuk, hogyan alakul az RBR fehérje- és a foszforilált P-RBR ${ }^{\mathrm{S} 911 \text { - }}$ szint a transzgenikus növények fejlődő első levélpárjában (31. ábra). Mind az RBR fehérje mennyisége, mind pedig a foszforiláltsági állapota drámaian megemelkedett a transzgenikus növény fiatal levelében (8 és 9 nap), majd lényegesen visszaesett a későbbi fejlődési időpontban (12 napos levél). Immunoprecipitálási kísérlettel azt vizsgáltuk, hogy komplexben található-e az E2FB és az RBR a transzgenikus növények levelében. Ennek során anti-DPA ellenanyag segítségével fehérje komplexet precipitáltunk fiatal (8 napos) csíranövények leveléböl, és az RBR és az E2FB fehérjéket specifikus ellenanyagok segítségével detektáltuk. Mind a két fehérje feldúsulását megfigyelhettük a DPA-val komplexben (31. ábra B), amely megerősítette, hogy az E2FB ebben a transzgenikus növényben is az RBR szigorú ellenőrzése alatt áll. Az RBR-E2FB-DPA komplex megnövekedett mennyiségéből arra következtethettünk, hogy az RBR az E2FB aktivitás egy jelentős részét kontrolálhatta, amely megmagyarázhatja a sejtszám csökkenését a fiatal 8 napos $\mathrm{E} 2 \mathrm{FB} / \mathrm{DPA}{ }^{\mathrm{OE}}$ növények levelében. A sejtciklus gének magas szintü expressziója arra utalhat, hogy azokban a sejtekben, ahol az E2FB/DPA felszabadult az RBR gátlása alól (magas RBR foszforiláció - 31. ábra A), ott feltehetően hiperaktiválódnak az E2FB célgének. 

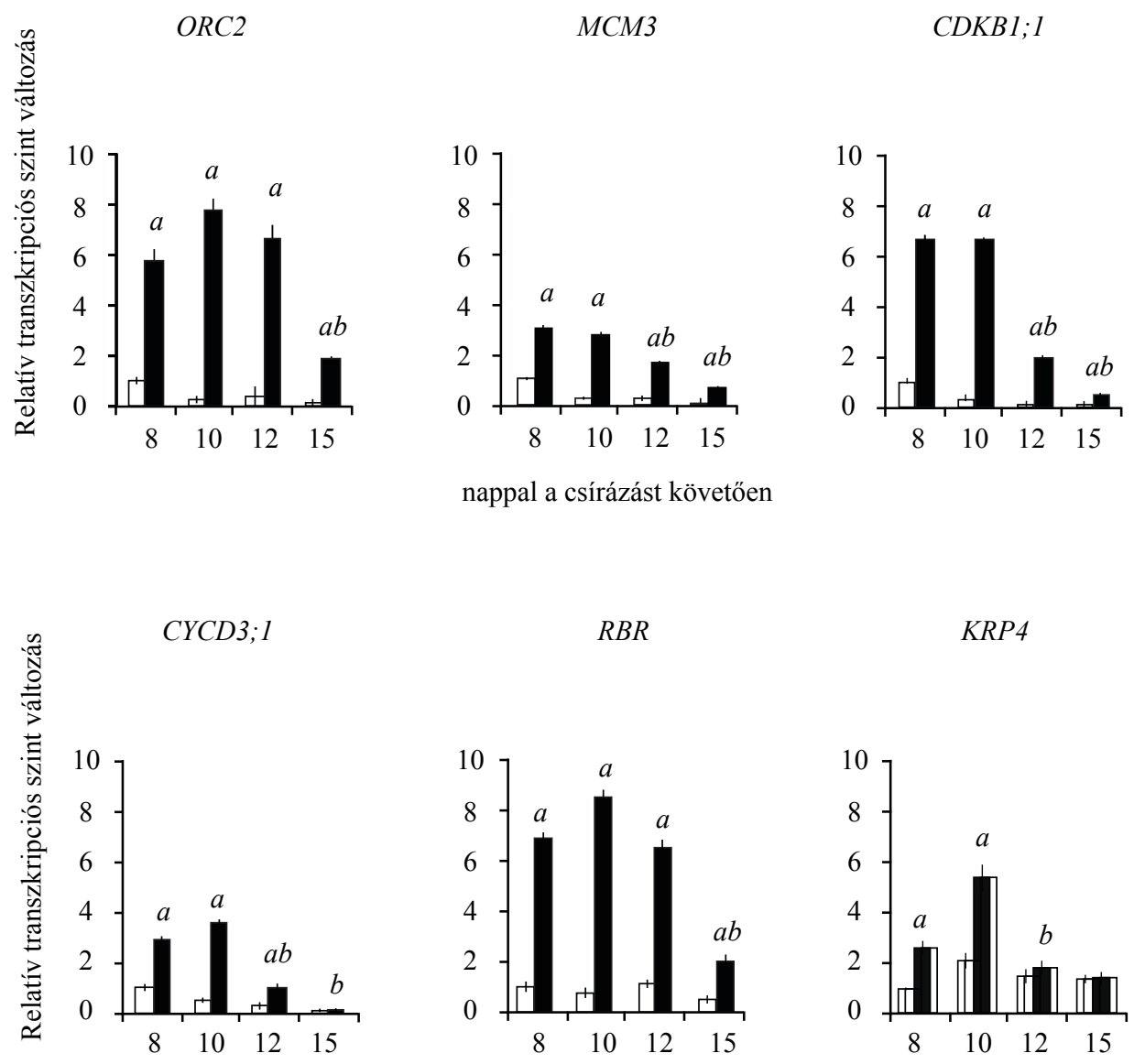

nappal a csírázást követően
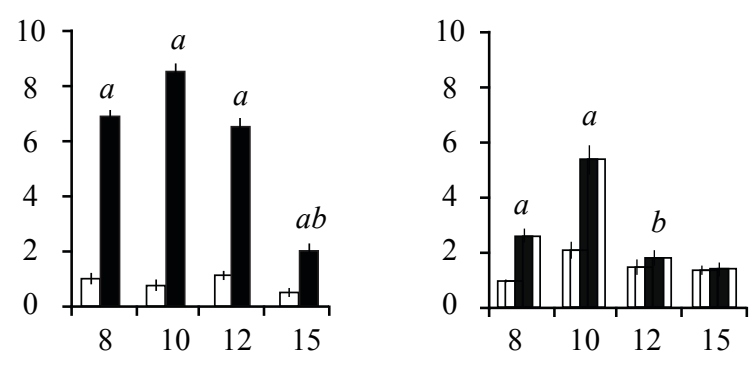

nappal a csírázást követően

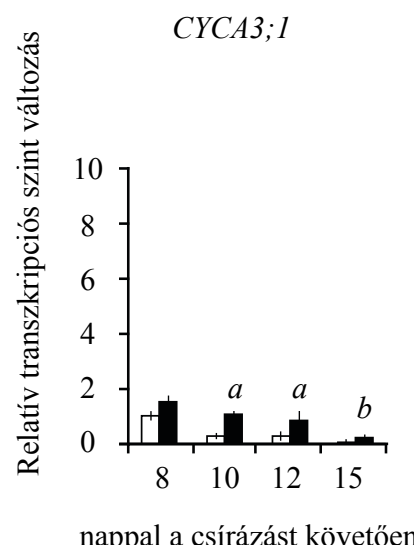

30. ábra. Az E2FB/DPA ${ }^{\mathrm{OE}}$ vonalban hiperaktiválódott a sejtciklus gének expressziója a levél fejlődése során Az ORC2, MCM3, CDKB1;1, CYCD3;1, RBR, KRP4 és CYCA3;1 relatív expressziós szintje vad típusú és E2FB/DPA ${ }^{\mathrm{OE}}$ növényekben RT-qPCR-ral vizsgálva. A minták az első levélpárból származnak 8, 10, 12 és 15 napos növényekböl. Az értékek az expressziós szint átlagát mutatják, amelyet a vad típusú növények 8 napos transzkripciós szintjéhez viszonyítottunk, amelyet egynek vettünk. A vonalak az oszlopok tetején a szórást jelölik, , $a ”$ jelölés a vad típus és a transzgenikus vonal közötti eltérés szignifikanciáját mutatja azonos vizsgálati időpontban, $\mathrm{p} \leq 0,05$ szignifikanciaszint mellett. A „b” jelölés az egymást követő vizsgálati időpontok közötti eltérés szignifikanciáját mutatja, szintén $\mathrm{p} \leq 0,05$ szignifikanciaszint mellett. A szignifikancia meghatározása Student-teszttel történt $(\mathrm{n}=3$, ahol „n” a biológiai ismétlések száma). A primereket Függelék I. A táblázata tartalmazza. 
A

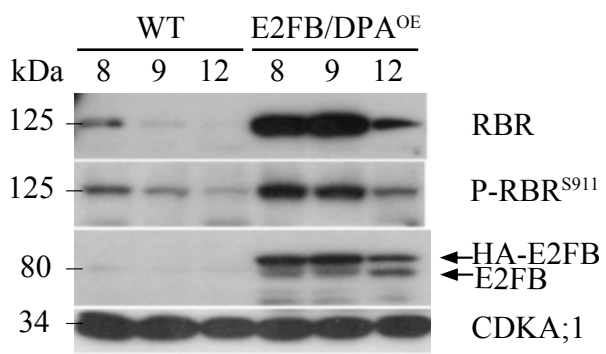

B

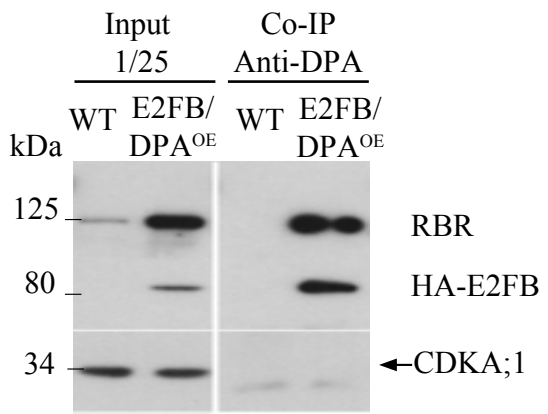

31. ábra. A p35S::HA-E2FB/DPA ${ }^{O E}$ növények levelében megnő az RBR és P-RBR szint és jelentős mennyiségü DPA-E2FB-RBR komplex formálódik

A) Az RBR, P-RBR ${ }^{\text {S911 }}$, HA-E2FB, E2FB és CDKA;1 fehérjék szintje a fejlődő első levélpárban vad típusú és $\mathrm{E} 2 \mathrm{FB} / \mathrm{DPA}{ }^{\mathrm{OE}}$ növények levelében 8,9 és 12 nappal a csírázást követően. A detekcióhoz anti-RBR, anti-P-RBR ${ }^{\mathrm{S} 911}$ (anti-P-Rb ${ }^{807 / 811}$ ), anti-E2FB és anti-CDKA;1 ellenanyagokat használtunk. B) Koimmunoprecipitációs kísérlet antiDPA ellenanyag segítségével. A minták 8 napos növények első levélpárjából származnak. A detekcióhoz anti-RBR, anti-E2FB és anti-CDKA;1 ellenanyagot használtunk. A CDKA;1 fehérje szint azonos mennyiségü mintafelvitelt jelez. Az input mintában koimmunoprecipitálásban használt összfehérje 1/25-ét vittük fel.

\subsubsection{Az E2FB az RBR fehérjével komplexben korlátozza a zárósejt merisztemoidok osztódását}

A növényi sejtciklusmodell szerint az E2F transzkripciós faktorok müködése döntően az RBRtől függ. Az RBR az aktivátor E2FA és E2FB fehérjékkel komplexben gátolja az aktivátor funkciójukat, amely nélkül nem kapcsolnak be a sejtciklus gének, és a sejtek nem tudnak belépni a sejtosztódási ciklusba. Ez a modell feltételezi azt is, hogy a két aktivátor E2F funkciója egymással jelentős mértékben átfed. Korábbi eredményeink azonban arra engednek következtetni, hogy az E2F fehérjék az RBR-rel komplexben közös represszor funkcióval is rendelkezhetnek. Egy deléciós E2FA (E2FA $\left.{ }^{\triangle \mathrm{RBR}}\right)$ mutáns segítségével kimutattuk, hogy az E2FA és az RBR közös gátló komplexben vesz részt, amely a levélfejlödés során megakadályozza az endociklus idő előtti bekapcsolódását (Magyar és mtsai., 2012). Kíváncsiak voltunk arra, hogy egy hasonló E2FB mutáns létrehozása milyen következményekkel jár a levél fejlődésére, és ez mennyiben fog hasonlítani az E2FA hasonló típusú mutánsához. Az E2FB C-terminálisáról 84 aminosav hosszúságú szakaszt deletáltunk, amely tartalmazta a konzerválódott RBR-kötő domént és a transzaktivációs régiót. A HA-E2FB ${ }^{\triangle R B R}$ konstrukciót a DPA-túltermelő növényekbe transzformáltuk (De Veylder és mtsai., 2002). Két független transzgenikus vonalat azonosítottunk (1-es és 10-es jelölésü transzgenikus vonalak). Mindkét transzgenikus vonal esetében hasonló fejlődési rendellenességeket és gátolt növekedést figyelhettünk meg in vitro és talajon egyaránt (32. ábra). A csíranövények mintegy 10-15\%-a mutatott abnormalitást a korai fejlődés során (pl. 3 sziklevél, hiányzó vagy fuzionált szervek, lásd 32. ábra B-E), amely arra utal, hogy már az embrionális fejlődés során jelentkeznek rendellenességek (32. ábra A-E). 

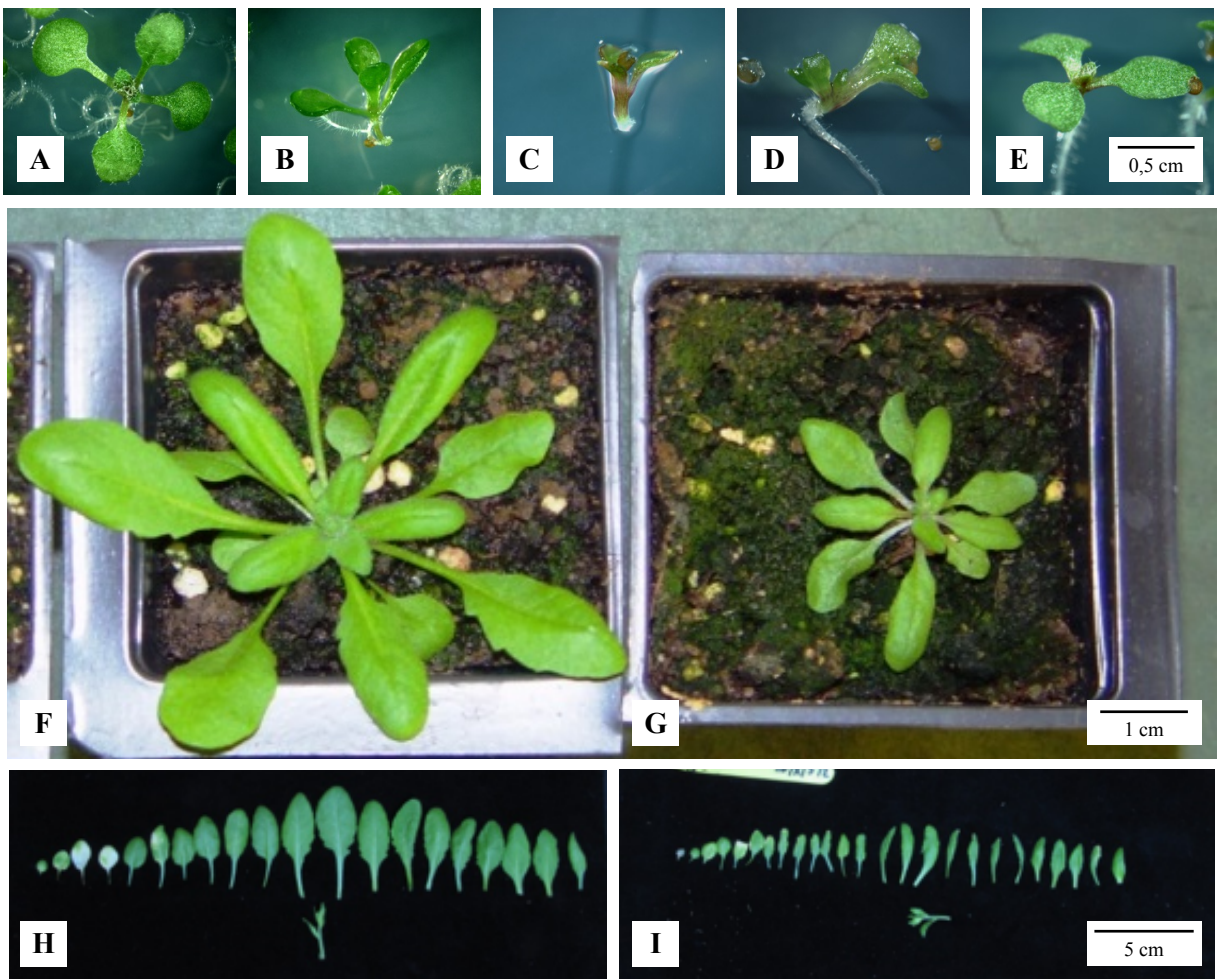

32. ábra. Az RBR kötésre képtelen E2FB mutáns (HA-E2FB $\left.{ }^{\triangle \mathrm{RBR}}\right)$ a DPA-val túltermeltetve gátolja a növényekés levelek növekedését, és fejlödési rendellenességekhez vezethet

A) vad típusú és B-E) abnormális szervfejlődést mutató $35 \mathrm{~S}:: H A-E 2 \mathrm{FB}^{\triangle \mathrm{RBR}} / \mathrm{DPA}$ csíranövények. Reprezentatív kép 20 napos, üvegházban növesztett F) vad típusú és G) 35S::HA-E2FB ${ }^{\triangle R B R} / D P A$ növényekröl. H) vad típusú és I) transzgenikus 35S::HA-E2FB ${ }^{\triangle R B R} / \mathrm{DPA} 28$ napos növények rozetta levelei. Méretskála az ábrákon jelölve.

A HA-taggelt E2FB ${ }^{\triangle \mathrm{RBR}}$ fehérjét nem sikerült kimutatnunk (nem bemutatott eredmény), ezért egy hasonló E2FB mutánst expresszáló transzgenikus növényt használtunk fel arra a célra (GFP-

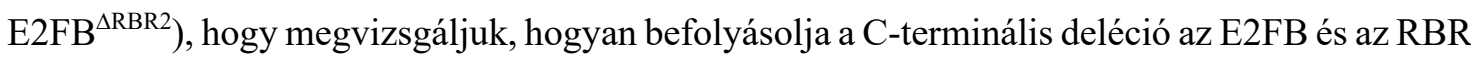
közti kölcsönhatást. Ezzel egyidejüleg egy hasonló GFP fúziós E2FA transzgenikus mutánst is elkészítettünk (GFP-E2FA ${ }^{\triangle \mathrm{RBR} 2}$ ). Fehérjekomplexeket precipitáltunk a GFP fúziós fehérjén keresztül (33. ábra A). A GFP fúziós E2FA és E2FB deléciós fehérjéket sikeresen immunoprecipitáltuk, és komplexben találtuk őket a DPB fehérjével. Az RBR fehérjét azonban nem tudtuk detektáltni az immunokomplexekben (33. ábra A). Ezek az eredmények arra engednek következtetni, hogy az E2FB deléciós mutáns fehérje feltehetően nem képes komplexbe lépni az RBR fehérjével, de a DP partnerekkel dimerizálva az E2F-specifikus célgénekhez kötődhet. Éppen ezért megvizsgáltuk, hogyan változik a sejtciklus célgének $(O R C 2$, $C D K B 1 ; 1, C Y C D 3 ; 1$ és $R B R$ ) kifejeződése az HA-E2FB ${ }^{\triangle R B R} / \mathrm{DPA}$ transzgenikus vonalak levelében. Az általunk vizsgált összes sejtciklus génnek jelentősen megnőtt az expressziója a transzgenikus levelekben a kontrollhoz képest (33. ábra B). Mindez arra enged következtetni, hogy az E2FB-RBR represszor-komplex hiányában a sejtciklus gének de-represszálódhatnak a fejlődő levélsejtekben. 

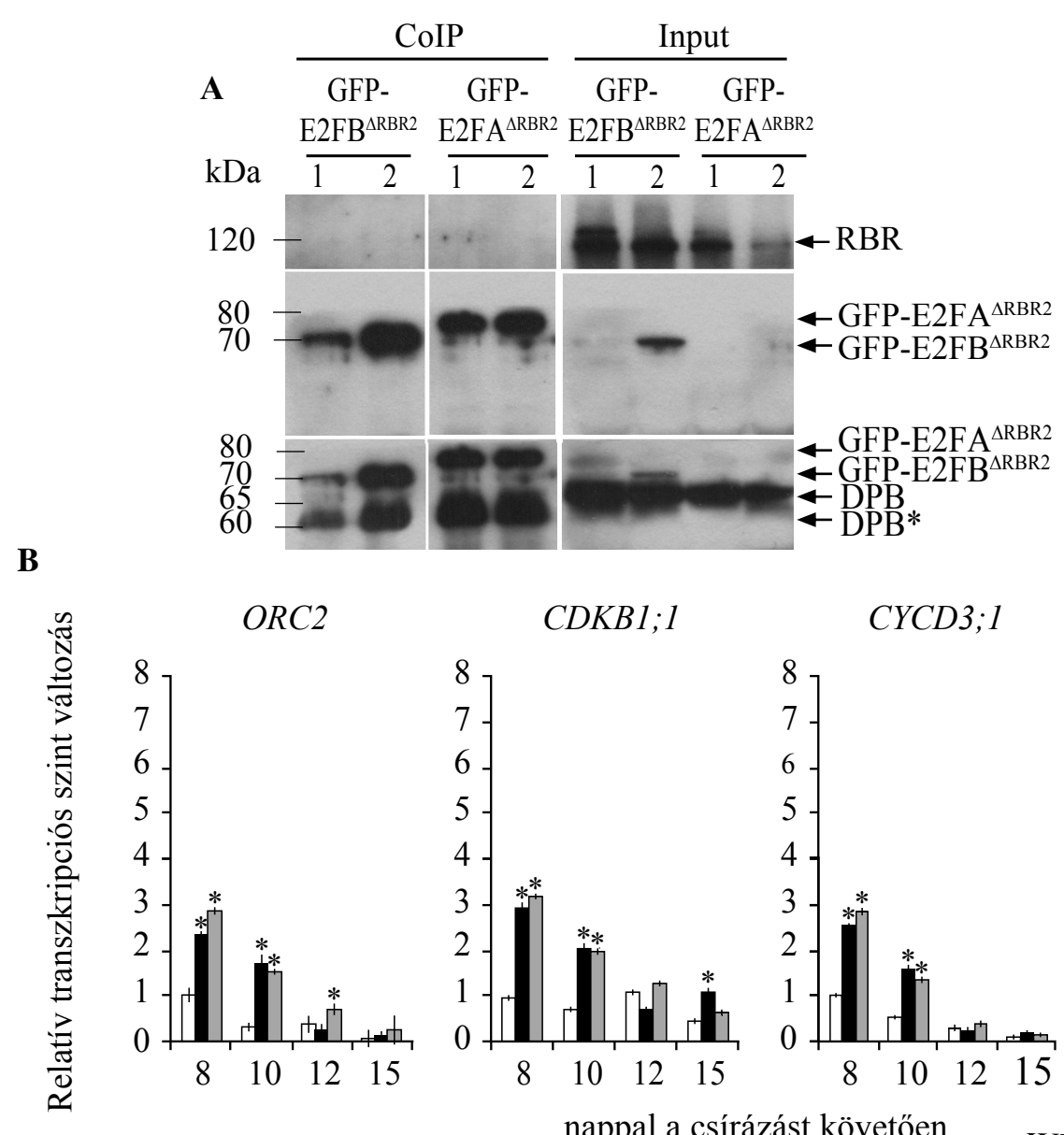

CYCD3;1

$R B R$
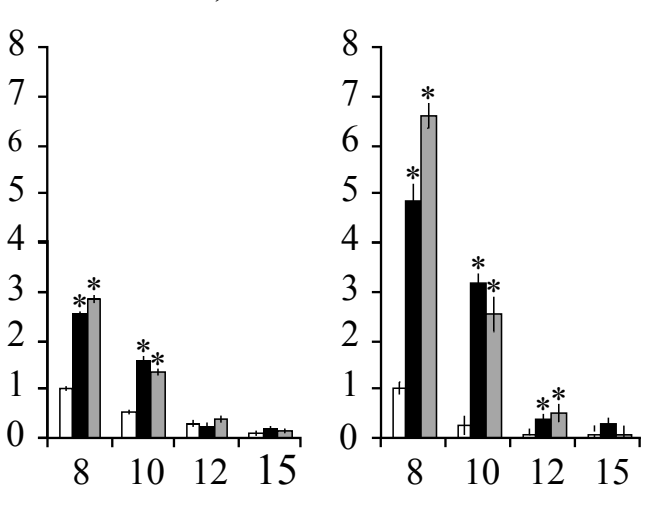

$\square \mathrm{WT}$
$\mathrm{HA}-\mathrm{E} 2 \mathrm{FB}^{\triangle \mathrm{RBR}} / \mathrm{DPA}$
$\mathrm{HA}$
$\mathrm{HA}-\mathrm{E} 2 \mathrm{FB}^{\triangle \mathrm{RBR}} / \mathrm{DPA}^{\mathrm{OE}} 1$

33. ábra. Sejtciklus E2F célgének de-represszálódtak a levél fejlődése során a HA-E2FB ${ }^{\Lambda R B R} / \mathrm{DPA}$ transzgenikus vonalakban

A) GFP-E2FB ${ }^{\triangle R B R 2}$ és GFP-E2FA ${ }^{\triangle R B R 2}$ transzgenikus növényekböl GFP-specifikus ellenanyag segítségével immunoprecipitáltuk (IP) a GFP-vel fuzionált mutáns fehérjéket, és anti-RBR és anti-DPB ellenanyagokkal megvizsgáltuk az RBR és DPB fehérjék jelenlétét az immunokomplexekben (CoIP). Az IP-hez használt mennyiség 1/12-ét használtuk az input mintákhoz (a western-blot jobb oldala). A csillaggal jelzett DPB fehérje a DPB-nek egy eltérő mobilitású formája. A molekulasúly marker a gél bal oldalán van jelölve. B) Az ORC2, CDKB 1;1, CYCD3;1 és $R B R$ relatív transzkripciós szintjének összehasonlítása az első levélpárban $8,10,12$ és 15 nappal a csírázást követően a két független HA-E2FB ${ }^{\triangle \mathrm{RBR}} / \mathrm{DPA}$ vonalban és vad típusú növényekben. Az analízis RT-qPCR alkalmazásával történt. Az értékek az expressziós szint átlagát mutatják, amelyet a vad típusú növények 8 napos transzkripciós szintjéhez viszonyítottunk, amelyet egynek vettünk $(\mathrm{n}=2$, ahol „n” a biológiai ismétlések száma). A vonalak az oszlopok tetején a szórást jelölik, „*” a referenciaszinthez viszonyított szignifikáns eltérést jelzi, $\mathrm{p} \leq 0,05$ szignifikanciaszint mellett. A szignifikancia meghatározása Student-teszttel történt a vad típusú és transzgenikus növények között a különböző időpontokban.

A magasabb expressziós adatok alapján a sejtosztódás aktivitása is fokozódhatott az E2FB mutáns növények leveleiben. Ezért megvizsgáltuk, hogyan változik a sejtosztódás központi aktivátorának, a CDK-nak az aktivitása a levél fejlődése során. Ennek érdekében különböző fejlődési állapotú mutáns és vad típusú levelek első levélpárjából A és B típusú CDK-kat tisztítottunk egy élesztő sejtciklus szabályozó fehérje segítségével (p13 $\left.{ }^{\mathrm{SUCl}}\right)$, majd radioaktív $\gamma$ ATP jelenlétében megvizsgáltuk az in vitro hiszton H1 kináz aktivitásukat (Magyar és mtsai., 2005). A kontroll növények leveleiben, ahogyan az várható volt, a legmagasabb hiszton H1 fehérje foszforiláltsági szintet a legfiatalabb levelekben figyelhettük meg (8. nap), majd a CDK 
aktivitása folyamatosan csökkent, és az utolsó, 15 napos levélben már csak alig detektálható szinten volt (34. ábra). Ezzel szemben a HA-E2FB ${ }^{\triangle R B R} / D P A$ vonal leveleiben minden vizsgált időpontban egyformán magas CDK aktivitást detektálhattunk (34. ábra). Ez alapján a transzgenikus HA-E2FB ${ }^{\triangle \mathrm{RBR}} / \mathrm{DPA}$ vonal leveleiben deregulálódott az osztódási aktivitás.

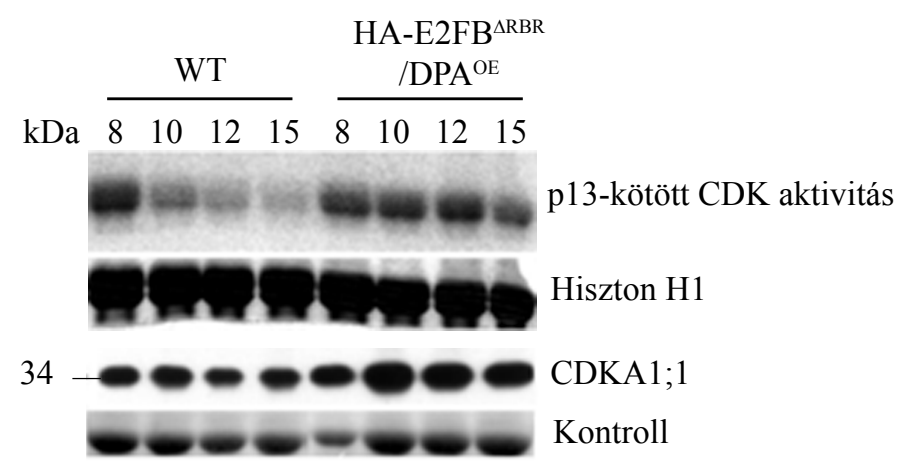

34. ábra. A sejtosztódás-specifikus totál CDK aktivitás konstitutívan magas a transzgenikus HA-E2FB ${ }^{\mathrm{ARBR}} / \mathrm{DPA}$ vonalak leveleiben

A CDKA és CDKB kinázok tisztítása p13 $3^{\text {sucl } 1}$ élesztő fehérjét tartalmazó affinitási oszlop segítségével történt. Az in vitro kinázaktivitás vizsgálatához egyenlő mennyiségü hiszton $\mathrm{H} 1$ fehérje szubsztrátot használtunk (Coomassiefestés). A levélmintákban nyomon követtük a CDKA1;1 fehérje szintjét is immunoblot segítségével, és a membránon található 50-60 kD közé eső aspecifikus fehérjét Coomassie festéssel láthatóvá tettük (Kontroll minta). A fehérjeminták vad típusú és HA-E2FB ${ }^{\triangle \mathrm{RBR}} / \mathrm{DPA}$ növények első levélpárjából származtak 4 különböző levélfejlődési időpontban $(8,10,12$ és 15 nappal a csírázást követően).

Kíváncsiak voltunk, vajon több levélsejt keletkezett-e az E2FB mutáns levelekben, mint a hasonló korú kontrollban. A korábban már leírt módon megvizsgáltuk a transzgenikus vonalak leveleit, megmértük a levelek és a börszöveti sejtek méretét és ebből meghatároztuk a levélsejtek számát 8, 10 és 12 nappal a csírázást követően (Függelék II. táblázat). A fiatal levélben még csökkenő sejtszámot láthattunk, de később, a 12. napnál jelentősen megemelkedett a sejtszám a kontrollhoz képest (Függelék II. táblázat). Az egyik legszembetünőbb változás a kisméretü sejtek $\left(\leq 300 \mu \mathrm{m}^{2}\right)$ megnövekedett száma volt a 10 és 12 napos levelekben (35. ábra G). Konfokális lézermikroszkóp alatt megvizsgáltuk az epidermális sejteket (35. ábra). A kontrollhoz képest kissejtes csoportosulásokat figyelhettünk meg a mutáns levélben az összes vizsgált időpontban (35. ábra D-F). A sejtek formája alapján feltételeztük, hogy ezek a kis sejtek a zárósejt merisztemoid sejtvonalhoz tartozhatnak. A merisztemoidok mérete a $60 \mu \mathrm{m}^{2}$ alatti tartományba esik (Dong, MacAlister és Bergmann, 2009), így kíváncsiak voltunk, hogyan változik az ennél kisebb méretü sejtek aránya a transzgenikus levelekben. A 12 napos levélben lényegesen megnőtt a merisztemoid méretü sejtek száma (35. ábra H). Mindez arra enged következtetni, hogy az E2FB deléciós mutáns levelében az epidermisz merisztemoid sejtek többet és hosszabb ideig osztódnak, mert az E2FB-RBR represszor komplex nem tudja kikapcsolni a sejtosztódási géneket. 

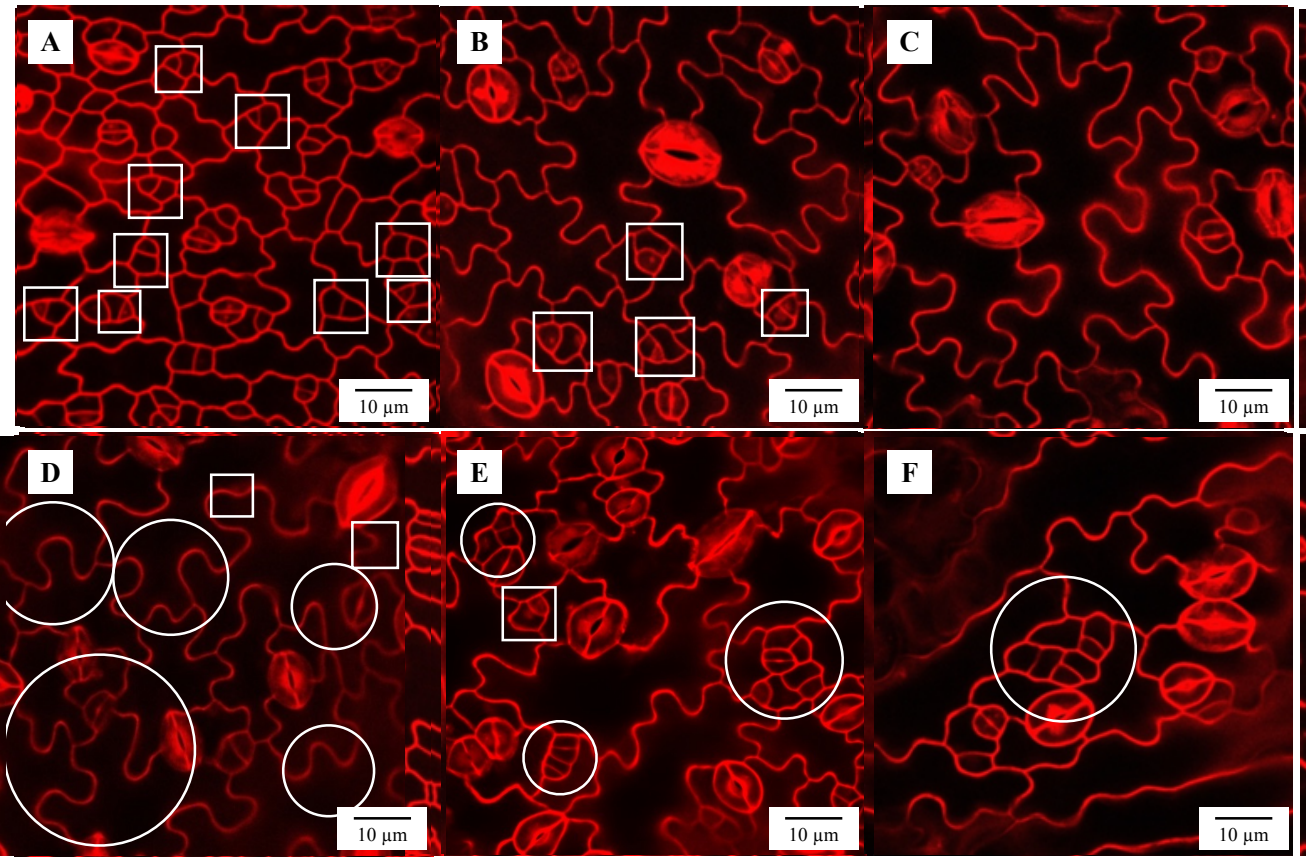

G

A sejtek méret szerinti megoszlása
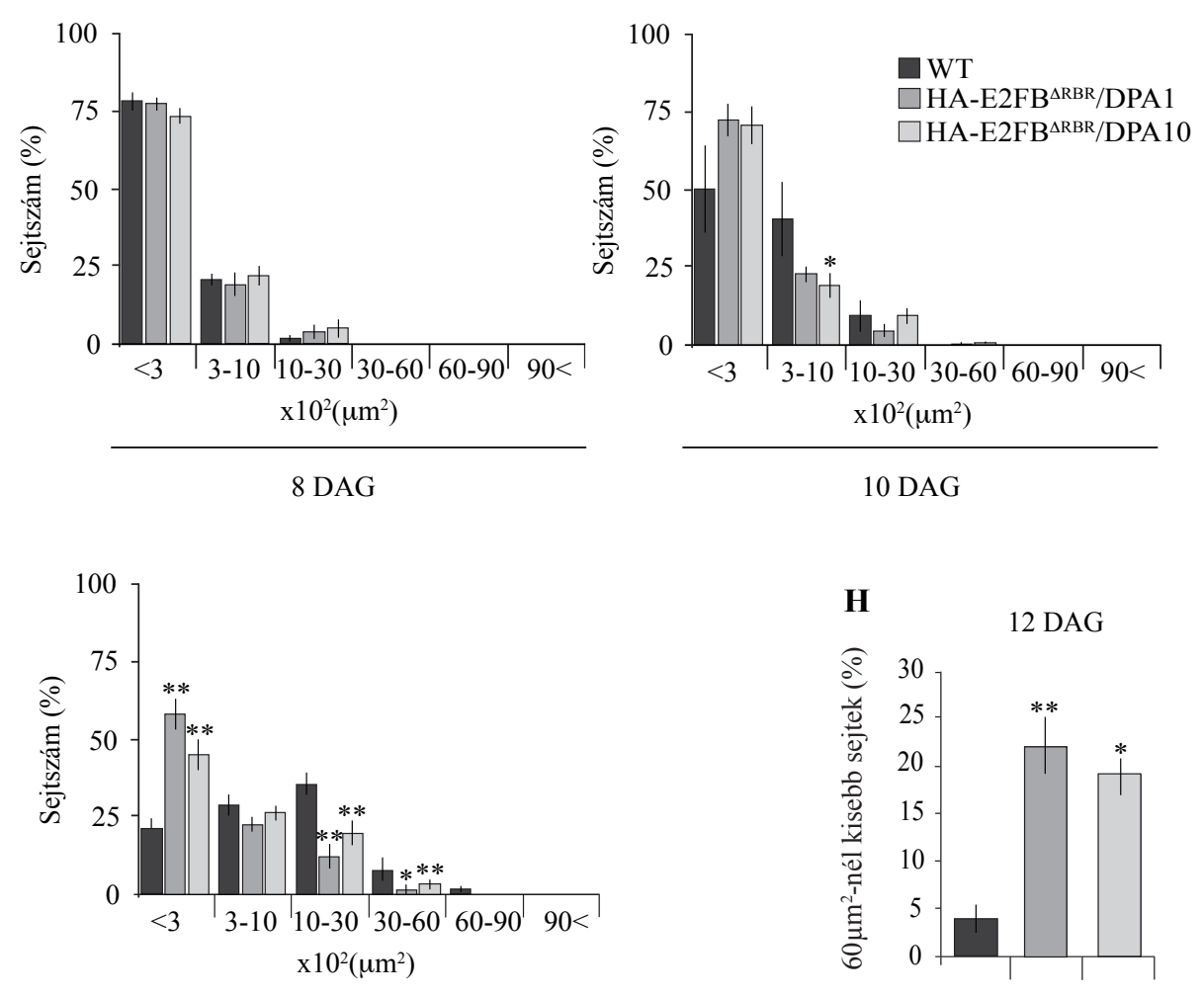

$12 \mathrm{DAG}$

35. ábra A HA-E2FB ${ }^{\triangle \mathrm{RBR}} / \mathrm{DPA}$ vonalak levelében hiperaktiválódott a zárósejt merisztemoidok osztódása Propídium-jodid festett konfokális mikroszkópos levél epidermisz képek A-C) vad típusú és D-F) HA-E2FB ${ }^{\triangle R B R} / D P A$ növények levelének abaxiális oldaláról. Balról jobbra haladva 8,10 és 12 nappal a csírázást követően. A négyszögek a normál merisztemoid csoportosulásokat jelzik, míg a körökön belül a nagyobb merisztemoid csoportosulások figyelhetők meg. A G) ábra az epidermális sejtek méretének százalékos megoszlását ábrázolja különböző levélfejlődési stádiumokban 8, 10 és 12 napos korban. A megoszlás nem tartalmazza a zárósejteket. A méréseket az első levélpáron végeztük 3 régióban (levél alap-, közép- és csúcsi régió). Szignifikáns különbség figyelhető meg a vad típusú növények és a transzgenikus vonalak között 10 és 12 napos korban. H) A $60 \mu \mathrm{m}^{2}$ alatti levélsejtek százalékos megoszlása 12 napos levél epidermiszében. (A G) és $H$ ) ábrákon $n=3, N>600$, ahol „n” a biológiai ismétlések száma és „N” a vizsgált sejtek száma / minta, **: $\mathrm{p} \leq 0,01, *: \mathrm{p} \leq 0,05$.) 
Az E2FA hasonló típusú mutációja során az endociklus hiperaktivációját figyelhettük meg (Magyar és mtsai., 2012). Megvizsgáltuk, vajon az HA-E2FB ${ }^{\triangle R B R} / D P A$ vonalak leveleiben változott-e a DNS ploidia szint a levél fejlődése során. Ezért áramlási citometria segítségével megmértük az első levélpárban található sejtek DNS tartalmát. Bemutatott eredményeink (36. ábra) alapján elmondható, hogy a transzgenikus vonalak leveleiben a vad típushoz hasonló DNS mennyiségeket detektáltunk mindhárom fejlődési időpontban. Ez alapján az E2FA és az E2FB hasonló mutációi eltérő változásokat generálnak, ami a két E2F faktor közti funkcionális különbségekre utal.

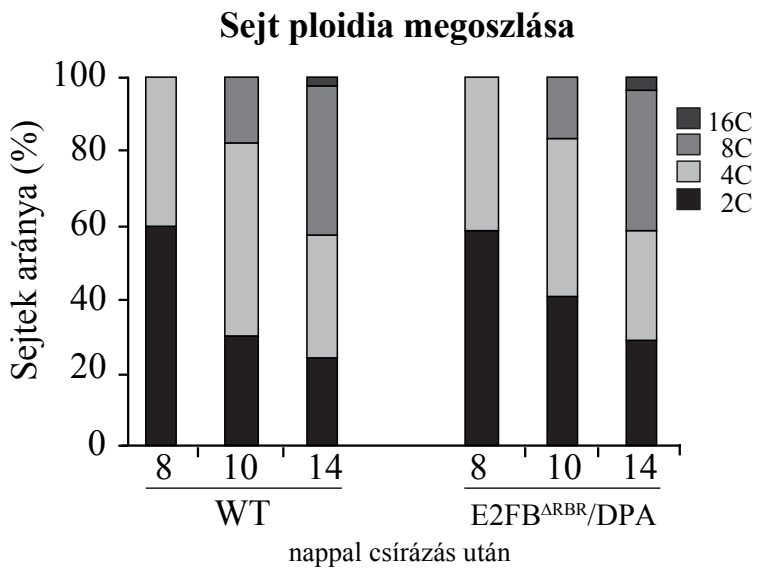

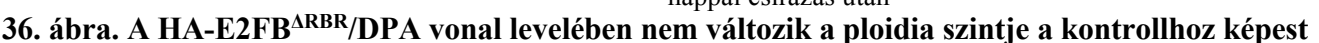

Az első levélpárban található sejtek ploidia szintjeinek megoszlása a vad típusú (bal oldal) és HA-E2FB ${ }^{\triangle R B R} / D P A$ (jobb oldal) növények leveleiben. A vizsgálat áramlási citometriával történt 8, 10 és 14 nappal a csírázást követően.

\subsection{Az E2FB funkciók deregulációja}

$\mathrm{Az}$ eddig bemutatott eredményeink alapján az E2FB transzkripciós faktornak legalább két formája van, amelyek eltérő szabályozási szereppel rendelkeznek: egy transzkripcionális aktivátor, amely az E2FB úgynevezett RBR-mentes vagy szabad formája, illetve egy represszor, ahol az E2FB az RBR-rel komplexben van. Ez a két forma a levél fejlődése során dinamikusan és sejttípustól függő módon változik. Az előzőekben bemutattuk, hogy az RBR nagyon érzékeny az E2FB fehérje szintjében és aktivitásában bekövetkező változásokra; az RNS, és különösen a fehérje szintje is szorosan követi az E2FB változásait. Még az E2FB nagyfokú túltermeltetésével is jelentős mennyiségü E2FB-RBR komplex jött létre, míg az E2FB RBR-kötésre alkalmatlan deléciós mutáns kifejeztetésével az E2FB elveszítette a transzaktivációs képességét is. Továbbra is szerettünk volna választ kapni arra a kérdésre, hogy mi történik akkor a növény fejlődésében és növekedésében, ha az E2FB RBR-mentes, szabad, aktivátor funkcióval rendelkező formája lesz a domináns? Vajon ebben az esetben az RBR-csendesített vonalakra jellemző fenotípusos elváltozásokat fogjuk-e látni, mint például kontrollálatlan sejtosztódást (Borghi és mtsai., 2010; Gutzat és mtsai., 2011), amely tumor jellegü sejtburjánzást eredményez, vagy fejlődési rendellensségekez vezet, mint amilyet a HA-E2FB ${ }^{\triangle R B R} / \mathrm{DPA}$ mutánsok esetében is megfigyelhettünk? 


\subsubsection{Az Arabidopsis RBR funkció gátlása mikroRNS segítségével specifikusan az E2FB- expresszáló sejtekben}

Az RBR funkciójának E2FB-specifikus gátlására egy mesterséges mikroRNS-t alkalmaztunk, amellyel korábban már sikeresen gátolták az RBR funkcióját. Ez egy 21 nukleotidnyi hosszúságú mesterséges mikroRNS-sel történt, amely az RBR 3' nem kódoló szakaszára lett tervezve (11. ábra; Cruz-Ramírez és mtsai., 2013). Ezt a mesterséges mikroRNS-t az E2FB kifejeződéséért felelös promóter szekvencia mögé klónoztuk, azzal a céllal, hogy azokban a sejtekben gátoljuk meg az RBR kifejeződését, ahol az E2FB expresszálódik. Feltételezésünk szerint így az E2FB felszabadulhat az RBR szabályozása alól. Transzgenikus növényeket hoztunk létre ezzel a konstrukcióval, és több mint 50 független transzformáns vonalat azonosítottunk (pE2FB::amiRBR). Ezek közül az egyik vonalban olyan fenotípusos elváltozásokat figyelhettünk meg, amelyeket korábban az RBR csendesítése során írtak le (részletesen lásd később).

Először megvizsgáltuk, termelődik-e mikroRNS a kiválasztott vonalunkban. Vizsgálatunkhoz kéthetes vad típusú kontroll (negatív kontroll), pE2FB::amiRBR, és pE2FC::amiRBR (azonos technikával elöállítva, mint a pE2FB::amiRBR konstrukció, ahol a csúcsi merisztéma müködésében láttunk defektust) csíranövényeket használtunk (Molnár E, nem közölt eredmények). A mikroRNS termelődését reverz transzkripciós kvantitatív PCR-ral detektáltuk (RT-qPCR). Az eredmények alapján a pE2FC::amiRBR vonalhoz képest alacsonyabb szinten tudtuk kimutatni a mikroRNS termelődését a vizsgált homozigóta $\mathrm{pE} 2 \mathrm{FB}$ ::amiRBR vonalban (37. ábra A). Azonban kérdéses volt, hogy ez az alacsony mennyiségben termelődő mikroRNS elegendő-e az RBR kifejeződésének a mérhető szintű redukálására. Ezért megvizsgáltuk, hogyan változik az RBR fehérje szint a pE2FB::amiRBR növényi vonalban a kontrollhoz képest. Tíznapos kontroll és pE2FB::amiRBR csíranövények sziklevelében specifikus ellenanyag segítségével western-blot módszerrel vizsgáltuk meg az RBR fehérje szintjét (37. ábra B). A kontrollhoz képest az RBR fehérje mennyisége jelentősen visszaesett a transzgenikus vonalból készített mintában, ami az RBR sikeres csendesítését igazolta. Az RBR fehérjével szemben ugyanakkor az E2FB szint nem mutatott lényeges különbséget a vad típusú és a transzgenikus növények sziklevele között. A sejtciklus szabályozó CDKA;1 és a mitotikus CDKB1;1 fehérjék viszont az pE2FB::amiRBR vonalunkban magasabb szinten voltak detektálhatóak, mint a kontrollban, amely aktív sejtosztódásra utal (Magyar és mtsai., 2005). Ezen felül a CDKB1;1 génröl korábban kimutattuk, hogy az E2FB specifikusan képes szabályozni a múködését. Ezért feltételeztük, hogy a transzgenikus növények sziklevelében az E2FB aktív formában volt jelen. Ennek igazolására immuntisztítási módszerrel, koimmunoprecipitálással (CoIP) megvizsgáltuk, kötődik-e az RBR fehérje az E2FB-hez a pE2FB::amiRBR növényekben (37. ábra B). A kontroll mintával szemben nem tudtunk az E2FB antitest segítségével RBR fehérjét precipitálni a transzgenikus növények szikleveléből. Ezek az eredmények arra engedtek következtetni, hogy 
az RBR-t sikerült csendesítenünk a transzgenikus növényi vonalban, és az RBR gátlás alól felszabadított E2FB aktiválta a sejtosztódás szabályozásában részt vevő géneket, mint amilyen a $\mathrm{CDKB} 1 ; 1$ is.

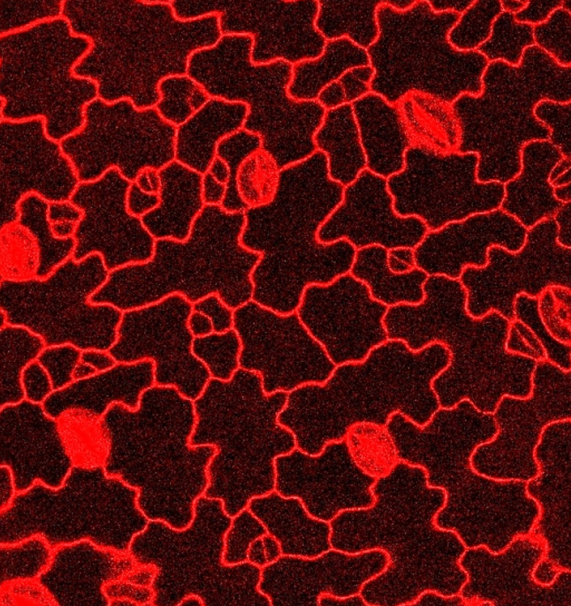

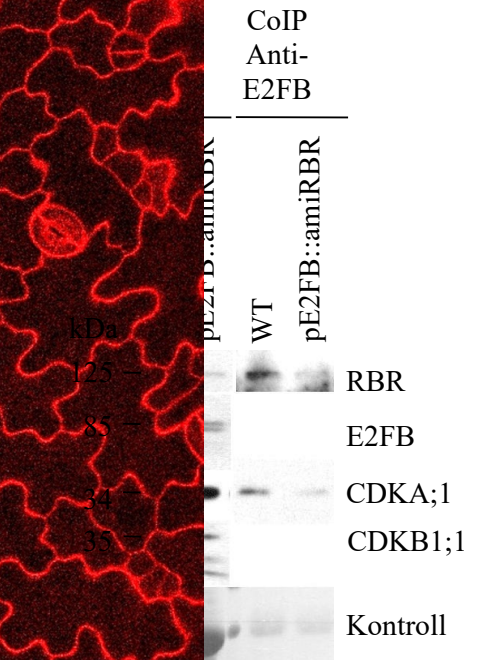

37. ábra. A pE2FB::amiRBR vonalban jelentősen redukálódott az RBR fehérje szint és az E2FB aktiválta a CDKB1;1 mitotikus kinázt

A) A mikroRNS relatív expressziós vizsgálata reverz transzkripciós kvantitatív PCR-ral történt 14 napos növényekböl. B) Tíznapos, vad típusú és transzgenikus (pE2FB::amiRBR) csíranövények szikleveléböl fehérjét tisztítottunk, majd 10\%-os SDS- poliakrilamid gélen (SDS-PAGE) molekulasúly szerint elválasztottuk őket (input - az ábra bal oldala). $\mathrm{Az}$ input mennyiség $(40 \mu \mathrm{g})$ nyolcszorosával immunoprecipitációt végeztünk (CoIP) az E2FB elleni specifikus ellenanyag segítségével (az ábra jobb oldala - CoIP, Anti-E2FB). Az RBR és a CDKA;1 fehérjék az E2FB fehérjével komplexben történő előfordulását, valamint az inputban található további fehérjék (CDKB1;1 és E2FB) mennyiségeit specifikus ellenanyagok segítségével immunoblot módszerrel vizsgáltuk. Az input fehérjemintákat azonos koncentrációban vittük fel a gélre, amit a membránon Coomassie Brilliant Blue festéssel tettünk láthatóvá (felviteli kontroll).

A pE2FB::amiRBR vonal fenotípusa hasonlóságot mutatott az indukálható RBR csendesített (RBR-RNAi, később röviden RBRi) mutáns növényekkel (38. ábra; Borghi és mtsai., 2010). A transzgenikus növényeink lényegesen kisebbek voltak, mint a hasonló korú kontroll növények, a levelek visszapöndörödtek a széleiken, korábban virágoztak, kisebb becőtermésük volt, és a maghozam jelentősen visszaesett. 

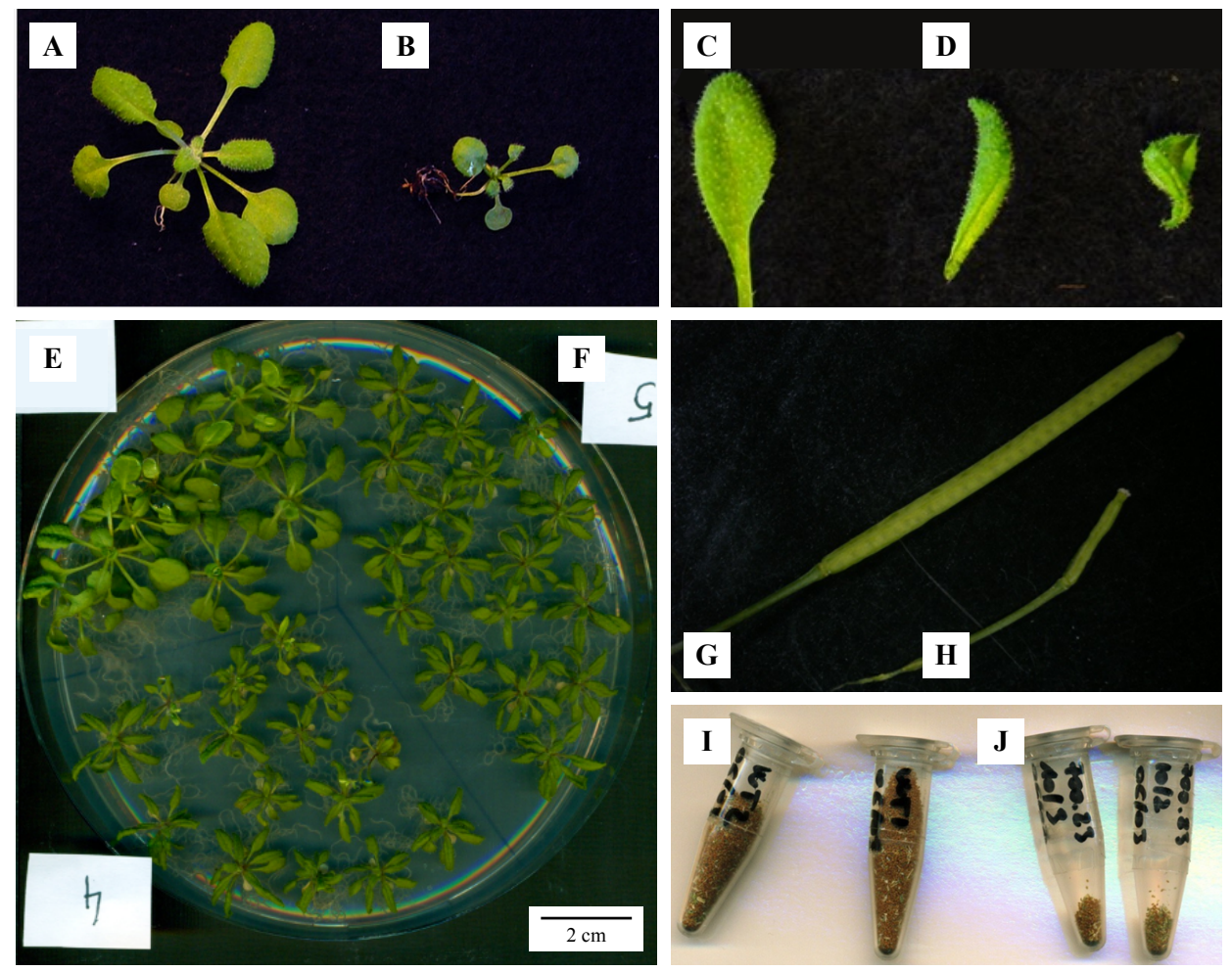

38. ábra. A pE2FB::amiRBR vonal az RBR-csendesített mutánsokra emlékeztető fenotípust eredményezett A-D) Az RBR csendesítését illusztráló fenotípus eredmények Borghi és munkatársai 2010-es cikkéből származnak. A) 19 napos vad típusú és B) RBRi Arabidopsis növények, amelyek $\beta$-ösztradiollal voltak kezelve a 14. naptól (Borghi és mtsai., 2010). C) A 6. számú vad típusú levél és D) az 5. és 6. számú RBRi levél 19 napos $\beta$-ösztradiollal kezelt növényekről (Borghi és mtsai., 2010). E) Vad típusú és F) pE2FB::amiRBR homozigóta növények 14 nappal a csírázást követően. G) A vad típusú és a $\mathbf{H})$ pE2FB::amiRBR homozigóta növények becőtermése. I) vad típusú és a J) transzgenikus vonalak maghozama egy-egy növényröl legyüjtve.

\subsubsection{Az RBR E2FB-specifikus csendesítése új fenotípusok megjelenéséhez vezetett}

Az Arabidopsis még az embrionális fejlődés során a globuláris stádiumban két sziklevelet fejleszt, amelyek a kontroll vad típusú csíranövényekben egymással szemben fejlődnek (Torres Ruiz, 2004). A pE2FB::amiRBR vonalunk esetében azonban jelentős százalékban ( 30\%) figyelhettünk meg olyan csíranövényeket, ahol a sziklevelek száma eltért a normálistól, vagy a két sziklevél nem egymással szemben, hanem egymás mellett helyezkedett el (39. ábra E-I). Ez a fenotípus nem volt egyedi jelenség az E2FB mutáns vonalakban, mert a korábban jellemzett $\mathrm{E} 2 \mathrm{FB}^{\triangle \mathrm{RBR}} / \mathrm{DPA}$ (32. ábra B-E) és az e2fabc tripla $\mathrm{E} 2 \mathrm{~F}$ mutáns vonalakban is megfigyeltünk hasonló elváltozásokat (nem publikált eredmények). A kotiledonok kifejlődésének pontos folyamata még nem teljesen tisztázott, azonban az auxin fontos szerepet játszik a kialakulásukban (Treml és mtsai., 2005). Így nem meglepő módon hasonló fejlődési rendellenességek tipikusan azokban a mutánsokban figyelhetők meg, ahol az auxin bioszintézisben (PINOID-, YUCCA-, TIR géncsalád), az auxin transzportjában (PINFORMED1 géncsalád), az auxin válaszban (MONOPTEROS, TOPLESS), az auxin szabályozásban (MACCHI-BOU4 ENHANCER OF PINOID) és transzkripciós regulációjában (CUP SHAPED COTYLEDON1-, HD-ZIP III-as géncsalád, SHOOTMERISTEMLESS) valamint a szterol(HYDRA1) és malonil CoA (GURKE) bioszintézisben szerepet játszó gének funkciója romlott el 
(39. ábra A-D) (Lenhard, Jürgens és Laux, 2002; Souter és mtsai., 2002; Hibara és mtsai., 2006; Cheng, Dai és Zhao, 2007 a; Cheng és mtsai., 2007 b; Furutani és mtsai., 2007; Chandler, 2008; Zhou, Roy és von Arnim, 2010; Huang és mtsai., 2014; Robert és mtsai., 2015).
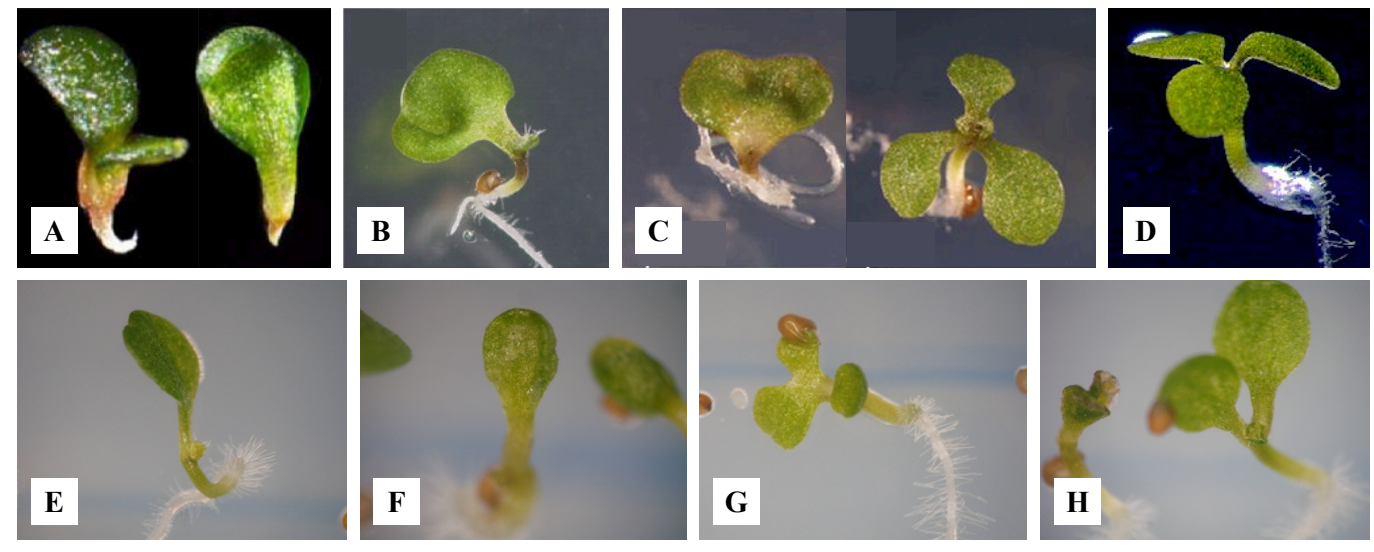

I

\begin{tabular}{|c|c|c|c|}
\hline & WT & pE2FB::amiRBR & p35S::amiRBR \\
\hline csírázási ráta & $100 \%$ & $80,64 \%$ & $77,04 \%$ \\
\hline 2 sziklevél & $100 \%$ & $69,99 \%$ & $97,86 \%$ \\
\hline 0 sziklevél & $0 \%$ & $3,99 \%$ & $2,11 \%$ \\
\hline 1 sziklevél & $0 \%$ & $23,99 \%$ & $0 \%$ \\
\hline 3 sziklevél & $0 \%$ & $1,99 \%$ & $0 \%$ \\
\hline
\end{tabular}

39. ábra. A pE2FB::amiRBR transzgenikus vonalban megváltozott az embrionális levelek száma és pozíciója Különbözö mutáns csíranövények megváltozott számú és pozíciójú sziklevelekkel. A) $m p$ (Zhou, Roy és von Arnim, 2010), B) mab 4-1(Furutani és mtsai., 2007), C) pin1-201 (Robert és mtsai., 2015), D) pid (Cheng és mtsai., 2007 b), és E-H) négy napos pE2FB::amiRBR csíranövények in vitro növesztve. I) A pE2FB::amiRBR csírázási aránya és sziklevélszáma a p35S::amiRBR és a vad típusú növényekhez viszonyítva. A sziklevélmegoszlás százalékos arányánál a kicsírázott növényeket vettük $100 \%$-nak.

Megfigyelhettünk olyan pE2FB::amiRBR csíranövényeket is, ahol nemcsak a sziklevél fejlődése szenvedett defektust, hanem a teljes csíranövény növekedése és fejlődése gátlódott (40. ábra). Előfordult, hogy a levélkezdemények megjelentek, de a gyökér egyáltalán nem fejlődött ki. Ezeken a növényeken sok esetben láthatóak voltak fehér szervkezdemények, amelyek feltehetően kotiledon és gyökér merisztémák lehettek. Paradicsomban végzett kísérletekben, ahol gátolták az auxin poláris transzportját NPA-val (naftiltálsav, amely egy auxin effluxot gátló szer) a levelek nem fejlődtek ki, azonban a merisztéma tovább növekedett, így tühöz hasonló organellumot alkotva. Hasonló fenotípus volt megfigyelhető a pin1 mutáns növényeknél (Reinhardt, Mandel és Kuhlemeier, 2000). Ezek a fejlődési rendellenességek arra engedtek következtetni, hogy a transzgenikus növényi vonalunkban az auxin transzportja sérült, amelynek köszönhetően abnormális helyeken jelentek meg a szerv primordiumok és kotiledonok. 

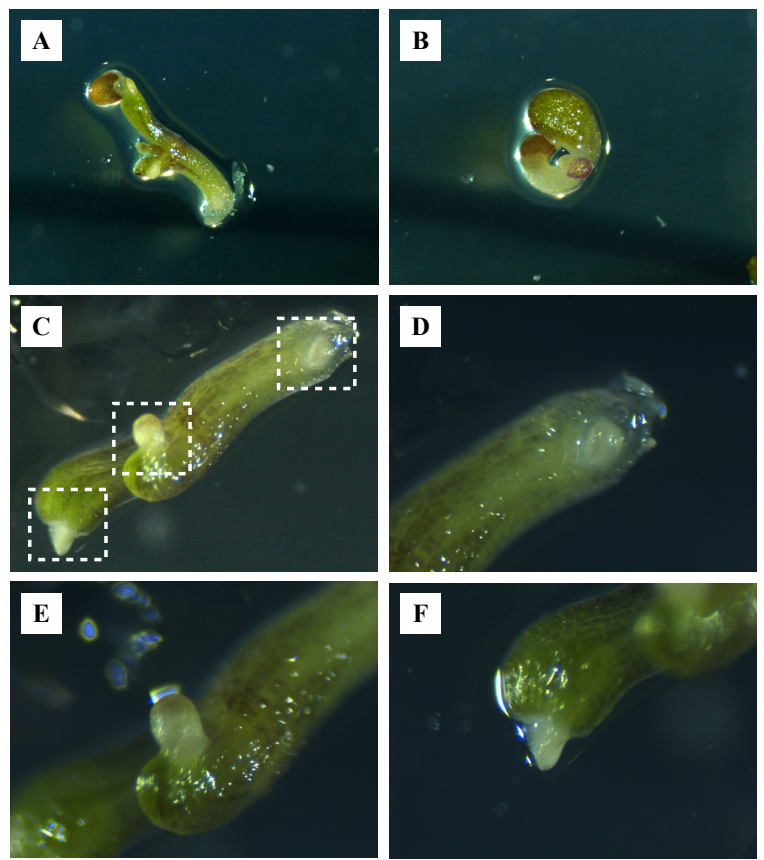

40. ábra. Gátolt fejlődésű pE2FB::amiRBR növények

A-F) Hétnapos csíranövények sztereomikroszkópos képe, amelyek csökevényes kotiledonnal rendelkeznek, és abnormális helyeken primordiumokat fejlesztenek. C) Szaggatott vonallal jelöltük az újonnan megjelent primordiumokat. D-F) A C képen szaggatott vonallal kiemelt területek kinagyított képe.

A pE2FB::amiRBR vonalban nemcsak a sziklevek, hanem az igazi levelek pozíciójában is rendellenességeket figyelhettünk meg (41. ábra). A levelek normálisan a hosszanti tengely körül spirálisan fejlődnek. A szabályozást, ami a levélsorrendet fenntartja, phyllotaxisnak hívjuk. A sziklevelek egymással szemben fejlődnek ki, akárcsak az első levélpár, amelyek a sziklevelekre merőlegesen formálódnak. Azonban ezt követően az új levelek egymással 137,5ºos szöget bezárva fejlődnek ki (Xiong és Jiao, 2019).

A pE2FB::amiRBR vonalban az egész vegetatív fejlödés alatt abnormális levélsorrendet lehetett megfigyelni. Ismert, hogy a phyllotaxis szabályozásának a hátterében is az auxin poláris eloszlása áll (Reinhardt és mtsai., 2003). Ezek a megfigyeléseink is arra engednek következtetni, hogy a pE2FB::amiRBR növényekben megváltozott az auxin eloszlása.
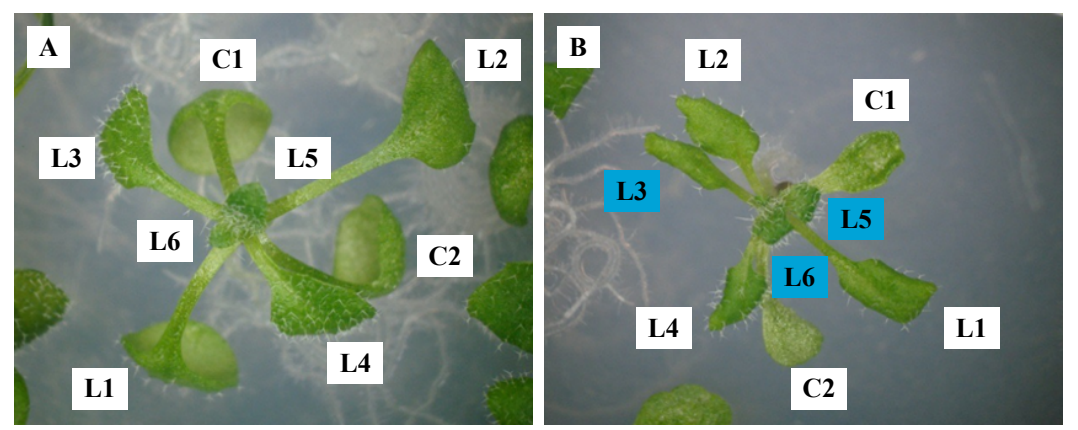

41. ábra. A pE2FB::amiRBR vonalban megváltozott a levelek sorrendje

A nagy C és L betűk a szikleveleket (C1-2) illetve a valódi leveleket (L1-2-3-4-5-6) jelzik, ahol a számok a levelek fejlödési sorrendjét mutatják. A fehér alapon található betük azokat a leveleket jelölik, amik a phyllotaxisnak megefelelően keletkeztek, míg a kék alapon található betűk az abnormális pozíciójú leveleket jelölik. A) A kontroll növényhez képest véletlenszerü eltéréseket lehetett megfigyelni a B) transzgenikus növények levélfejlődési sorrendjében. 
Nemcsak a hajtás szintjén, de a transzgenikus vonalunk gyökereinél is megfigyelhettünk rendellenességeket. Egyfelöl rövidebbre nőttek, mint a hasonló korú vad típusú kontroll növények gyökerei. Másfelől a transzgenikus gyökerek növekedésének az iránya is eltért a normálistól, extrém esetekben a gravitációs ingerre merőlegesen, vagy azzal ellentétesen növekedtek, gyakran kisebb kanyarokat, hurkokat írtak le (42. ábra B). Hasonló gyökérnövekedési anomáliákat figyeltek meg egyes auxintranszport-mutánsokban, ahol például az AUXIN TRANSPORTER PROTEIN 1 (AUX1) auxin influx karriert vagy a PIN2 (PINFORMED2) auxin efflux csatornát mutáltatták el (42. ábra C-D; Wu és mtsai., 2015).
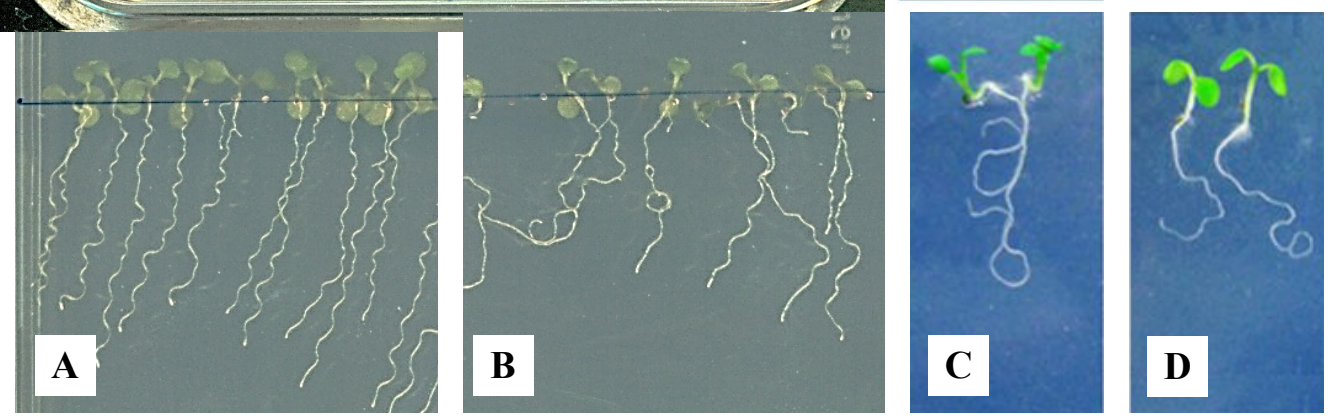

42. ábra. A pE2FB::amiRBR növények gyökerei módosult növekedési mintázatot mutatnak

A) vad típusú és B) pE2FB::amiRBR csíranövények folyamatos fényen, függöleges lemezen 7 napig növesztve. C) aux 1 (Wu és mtsai., 2015) és D) pin2 (Wu és mtsai., 2015) mutáns növények, amely szintén agravitropikus növekedést mutatnak.

A gyökér növekedésében látott abnormalitások arra engednek következtetni, hogy a transzgenikus növények gyökere a gravitációs ingerre csak részben tud válaszolni. A növényeket függőleges lemezen növesztettük, majd megvizsgáltuk a gyökerek kanyarodási fokát, amely szignifikáns különbséget mutatott a vad típusú növényekhez képest (43. ábra A; Wu és mtsai., 2015).

Megvizsgáltuk, hogy a pE2FB::amiRBR növények gyökerei képesek-e növekedésükkel a gravitációs változásokat követni. Ezért függőleges helyzetü lemezeken növesztettük egy hétig a kontroll és a pE2FB::amiRBR csíranövényeket, majd merölegesen, $90^{\circ}$-os szögben elfordítottuk öket. A forgatást követő 4. és 8. óra eltelte után képeket készítettünk a lemezekröl és megvizsgáltuk, milyen mértékben követték a traszgenikus gyökerek a gravitációs ingert a vad típusú növényekhez viszonyítva (43. ábra B-E). Megállapíthattuk, hogy a transzgenikus növények gyökerei kevésbé válaszoltak a gravitációs inger megváltozására, mint a kontroll gyökerek. Nyolc órával a forgatást követően a transzgenikus gyökerek nagyobb százaléka közelítette meg a $90^{\circ}$-os elfordulást, de arányuk még mindig jelentős mértékben elmaradt a vad típusú növények gyökérválaszától. Ez alapján elmondható, hogy a transzgenikus növények lassabban érzékelik a gravitációs változásokat és/vagy lassabban válaszolnak rájuk. 
$\mathbf{A}$

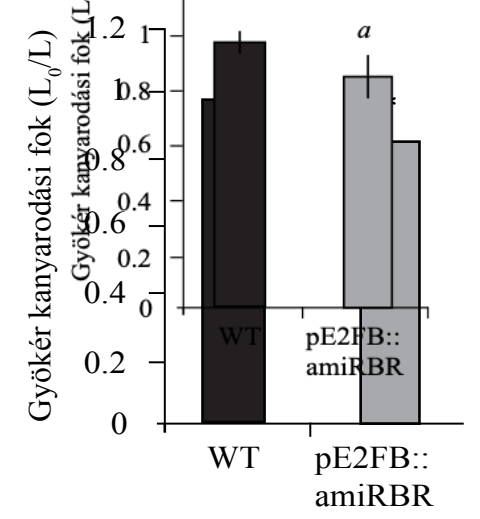

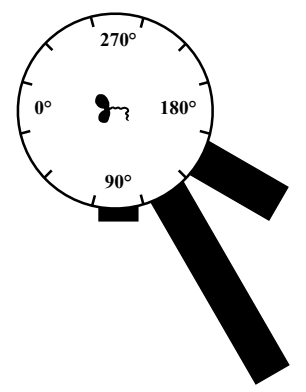

C

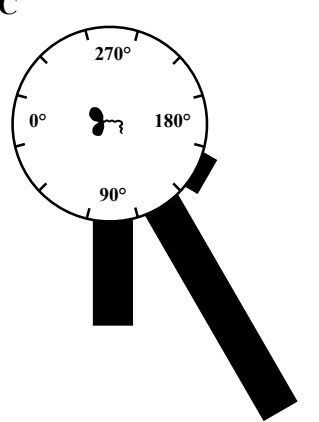

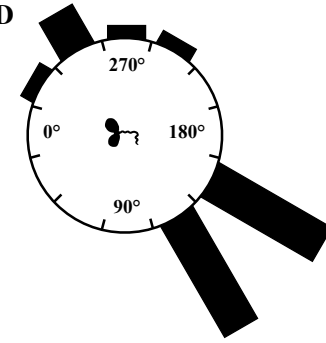

$\mathbf{E}$

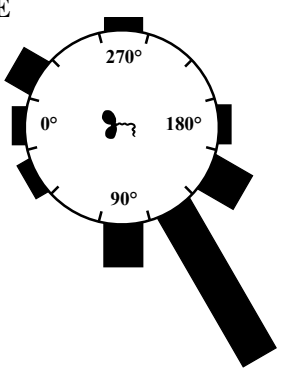

43. ábra. A transzgenikus pE2FB::amiRBR növények gyökerei lassabban reagálnak a gravitációs inger változására, mint a vad típusú növények

A) Hétnapos, függőleges lemezen növesztett növények gyökerének kanyarodási foka. „," szignifikáns eltérést jelent a referenciaértékhez képest, $p \leq 0,05$ szignifikanciaszint mellett. B-C) Vad típusú és D-E) pE2FB::amiRBR növények $90^{\circ}$-os elforgatást követően 4 illetve 8 óra (föntről lefelé) elteltével mért válaszreakciói a gravitációs ingerre.

A gravitációs inger változása során a fizikai információ kémiai szignállá transzformálódik át. A gyökérben ennek a mechanizmusnak a helyszíne a gyökérsüveg. A gravitációs ingert a gyökérsüveg sejtjei érzékelik, amelyek a nyugvó centrumtól (angolul quiescent center, röviden és a későbbiekben QC) disztálisan található kolumella sejtek, amelyek félkörös horizontális rétegekből (story, röviden S) épülnek fel. (Blancaflor, Fasano és Gilroy ,1998). A kolumella sejtekben helyezkednek el a keményítőt termelő és raktározó amiloplasztok, amelyek elmozdulása az auxin egyenlőtlen eloszlásához, ezáltal a gyökér növekedésének megváltozásához vezet (Cholodny-Went elmélet; Trewavas, 1992; Zheng és Staehelin, 2001).

Kíváncsiak voltunk, vajon a transzgenikus gyökerek rendelkeznek-e keményitőszemcsékkel a gyökérsüvegben. Ezért megfestettük őket a keményítő kimutatására alkalmas Lugol festékkel (44. ábra). Az eredmények alapján megállapíthatjuk, hogy a keményítőszemcsék, így az amiloplasztok, jelen vannak a transzgenikus növények gyökerében, bár eloszlásuk a kontrollhoz képest sokkal kevésbé rendezett. 


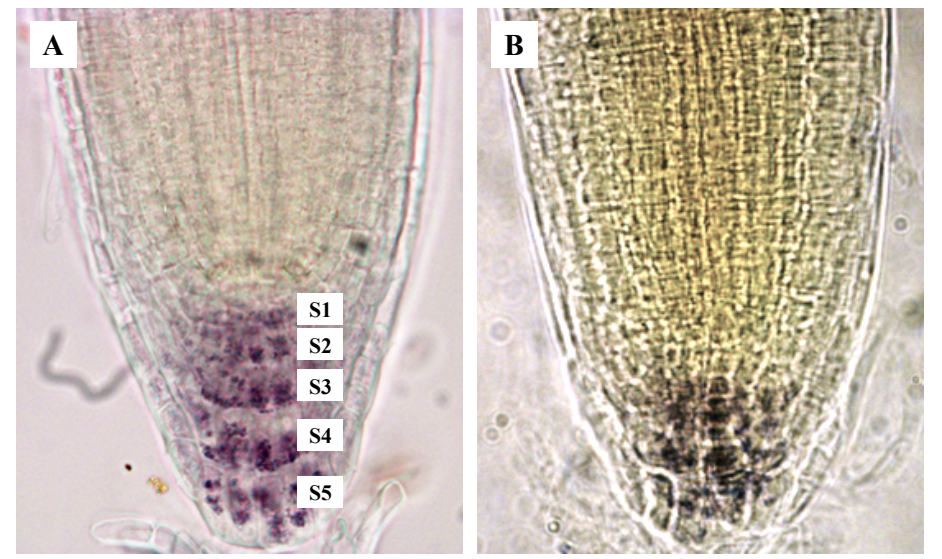

44. ábra. A pE2FB::amiRBR vonal gyökereiben kimutathatóak a keményítőszemcsék

Néhány napos, függöleges lemezen növesztett csíranövény gyökeréről készített Lugol festéses kép Cell-R mikroszkóp segítségével. A) vad típusú növény B) pE2FB::amiRBR növény gyökér merisztémájának alsó része a gyökérsüveggel. Sötétlilásan és -barnásan a keményítőszemcsék festődése látható. A színbeli eltérést a festés időtartama okozza (barna = hosszabb festési idö). A vad típusú növényen S1-től S5-ig jelöltük a kolumella rétegeket (story = S, S1=a nyugvó centrumhoz legközelebb eső, S5= a nyugvó centrumtól legtávolabb eső), amelyek a transzgenikus növényen nem voltak elkülöníthetőek.

A gyökérsüveg sejtjeinek rendezetlensége a gyökér szerkezeti, felépítési problémáira utalt. Ezért propídium-jodid festést követően konfokális lézermikroszkóppal vizsgáltuk a transzgenikus növények gyökereit (45. ábra). A transzgenikus gyökérben számtalan abnormalitást figyelhettünk meg; egyrészt kisebb és dezorganizált gyökérsüveget, valamint, főleg az epidermisz és a kérgi sejtvonalban, rossz irányú sejtosztódásokat lehetett megfigyelni, amelyek új sejtvonalakat generáltak (45. ábra B).
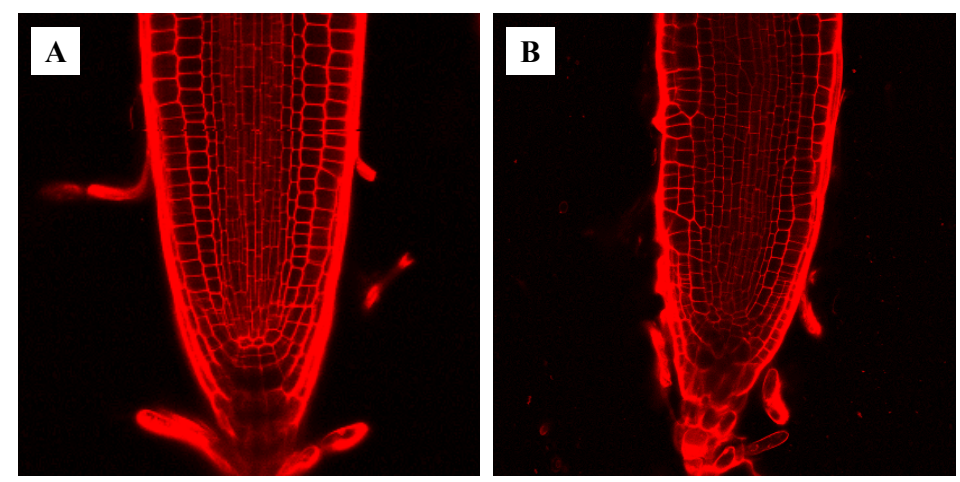

45. ábra A pE2FB::amiRBR növények gyökerei szerkezeti eltéréseket mutatnak a kontroll növények gyökereihez képest

Hétnapos A) WT és B) pE2FB::ami RBR gyökerek gyökérsüvegéről és a merisztéma alsó részéről készített konfokális mikroszkópiás képek propídium-jodid festést követően (piros jel = sejtfal).

Ismert, hogy a gyökérben az auxin meghatározó szerepet játszik a sejtosztódás szabályozásában, az osztódásba lépésben, a merisztematikus osztódások fenntartásában, valamint a specifikus sejtmintázat kialakításában is (Perrot-Rechenmann, 2010). A G1 fázisban az auxin indukálja a CIKLIND3;1 és a CDKA; 1 expresszióját, stabilizálja a kialakuló CDK-ciklin komplexeket, és gátolja a KRP1 és KRP2 CDK-inhibitorok expresszióját. A ciklin-CDK komplexek foszforilálják az RBR-t, így az E2FB felszabadul a gátlás alól, és aktiválja az S fázisú szabályozó gének 
expresszióját (Wang és Ruan, 2013). Ezzel szemben a citokininek a gyökérsejtek differenciálódásában játszanak fontos szerepet (Schaller, Street és Kieber, 2014). Kíváncsiak voltunk, vajon exogén citokinin hozzáadásával helyre tudjuk-e állítani a transzgenikus gyökerekben megfigyelt abnormalitásokat? Ezért kontroll és transzgenikus növényeket auxin (10 $\mathrm{nM}$ indol-3-ecetsav) és citokinin ( $0,1 \mu \mathrm{M}$ transz-zeatin) tartalmú lemezeken növesztettünk, majd egy hét múlva konfokális mikroszkóp alatt megvizsgáltuk őket. Auxin hatására nem javult a sejtek organizációja a pE2FB::amiRBR gyökércsúcsban, sőt, tovább nőtt a rendezetlenség, különösen a QC (nyugvó centrum) körül és a gyökérsüveg kolumella sejtrétegeiben (46. ábra C). Ezzel szemben transz-zeatin hatására a kolumella sejtrétegek a kontroll vad típusú növényekre emlékeztető rendezettséget mutattak (46. ábra A-B). Megvizsgáltuk a gyökerek gravitációs ingerre adott növekedési válaszát is $1 / 2 \mathrm{GM}$ és az előzőekben említett hormon tartalmú táptalajokon (46. ábra D). A citokininen növesztett transzgenikus növények nagyobb mértékben voltak képesek a gravitációs inger irányának megfelelően nőni, mint a hormonmentes táptalajon növesztett növények. Abban az esetben, ha a transzgenikus növényeket auxin tartalmú táptalajon növesztettük, a növények még kevésbé voltak képesek a gravitációs ingerre válaszolni. Ezen eredmény alapján elmondhatjuk, hogy a kinetin jelentős mértékben képes helyreállítani a mutáns gyökerek kolumella sejtrétegeit, és ezáltal normalizálni a gravitációs ingerre adott válaszreakciót.
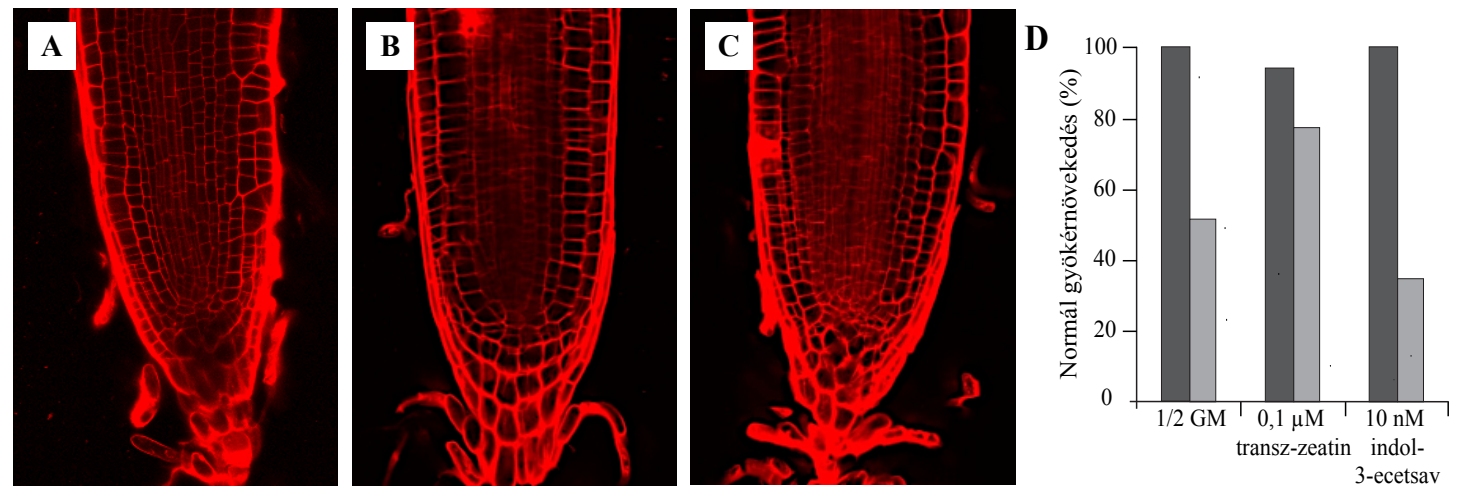

46. ábra. Citokinin hatására az pE2FB::amiRBR transzgenikus növényben rendezettebb gyökérsüveg fejlődőtt és a gravitációs ingerre adott válasza is jelentősen javult

A pE2FB::amiRBR vonal gyökérsüvegéről készített képek, propídium-jodid festéssel, konfokális mikroszkóp alatt. A növényeket A) sima csíráztató B) transz-zeatin (t-Z) tartalmú és C) indol-3-ecetsav (IAA) tartalmú táptalajon növesztettük 7 napon keresztül. D) $t$-Z hatására a növekvő gyökerek nagyobb mértékben tudták követni a gravitációs ingert, míg IAA hatására tovább romlott ez a tendencia.

Mindez arra utal, hogy a transzgenikus gyökerek kolumellarétegében extra és/vagy dezorientált sejtosztódások miatt jön létre a rendezetlen kolumella sejtréteg és a gyökérnövekedés abnormalitása. Ennek az állításnak további alátámasztása céljából megfestettük a transzgenikus gyökereinket 5-etinil-2-deoxiuridinnal (EdU). Az EdU egy timidin analóg, amely képes a szintetizálódó DNS-be inkorporálódni, tehát ezzel a módszerrel láthatóvá tehetőek az osztódó sejtek. Hat napig a kontroll és a transzgenikus csíranövényeinket függőleges lemezeken növesztettük hormonmentes $(1 / 2 \mathrm{GM})$, valamint transz-zeatint $(\mathrm{t}-\mathrm{Z}, 0,1 \mu \mathrm{M})$ vagy auxint (IAA, 
$10 \mathrm{nM}$ ) tartalmazó lemezeken. Az eredmények alapján a pE2FB::amiRBR gyökérsüveg kolumella sejtjei között mind a hormonmentesen, mind pedig a hormonon növesztett gyökerek (nem bemutatott eredmények) esetében csak elvétve lehetett detektálni EdU pozitív sejteket (47. ábra). Ez alapján az pE2FB::amiRBR gyökérsüvegében nincs több osztódó sejt, mint a kontrollban, tehát a kolumella sejtek rendezetlensége feltehetően a kolumella őssejtek osztódásainak rossz orientációja miatt alakulhat ki. A kontroll, nem kezelt gyökerekhez képest lényegesen gyengébb EdU jelet láthattunk a pE2FB::amiRBR gyökér merisztémában, ami arra enged következtetni, hogy a sejtosztódások gyakorisága csökkent a transzgenikus gyökérben. Megállapíthatjuk, hogy kinetin hatására jelentősen csökkent a teljes gyökér merisztémában az EdU-pozitív sejtek száma, ami megerősítette a korábbi, citokininnel gyökéren kapott eredményeket (Dello Ioio és mtsai., 2012; Schaller, Street és Kieber, 2014; Street és mtsai., 2016). Ezen eredmények alapján elmondható, hogy a kinetin gátolja a sejtek osztódását, ezáltal megakadályozhatja a dezorientált sejtosztódást is a transzgenikus növényekben, helyreállítva ezzel a kolumella rétegeket és a gravitációs ingerre adott válaszreakciót.
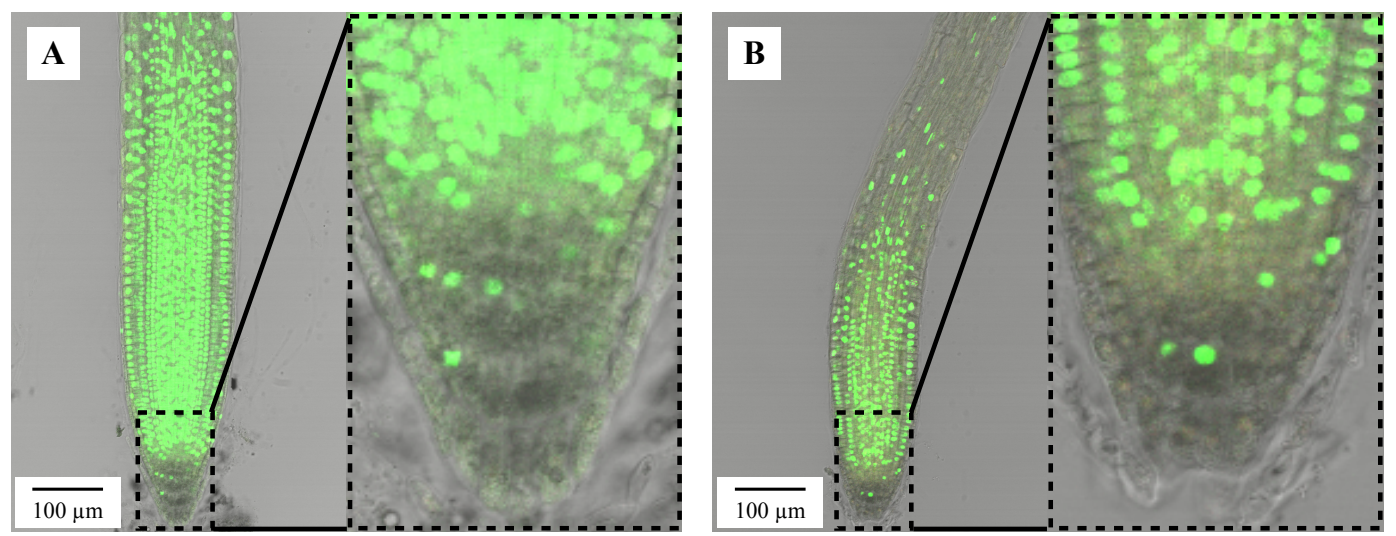

47. ábra. A pE2FB::amiRBR transzgenikus vonal gyökérmerisztéma sejtjei kevesebbet osztódnak, mint a vad típusú növények, azonban a kolumella réteg sejtjeinek osztódása nem mutat szignifikáns különbséget 6 napos A) vad típusú és B) pE2FB::amiRBR növények 1/2 GM-en növesztve 3óra EdU festést követően. Az ábrák jobb oldalán látható képek a szaggatott vonal kiemelt régiók kinagyításai. Méretskála: $100 \mu \mathrm{m}$ (az ábrán jelezve, a méretskálák az ábrák bal oldalán feltüntetett képekre vonatkoznak).

Az auxin fontos szerepet játszik a sejtek osztódásában és differenciálódásában. Hogy megtudjuk, megváltozott-e az auxin gyökérmerisztéma-specifikus megoszlása a pE2FB::amiRBR növények gyökerében a kontrollhoz képest, a transzgenikus növényünket kereszteztük az auxin riporter pDR5-GFP konstrukciót tartalmazó növénnyel. A DR5 egy auxin-szenzitív szintetikus promóter, amely ebben az esetben egy nukleáris lokalizációt kódoló fluoreszcens GFP expresszióját szabályozta. A heterozigóta első T0 generáció utáni T1 generációban konfokális mikroszkóp alatt kerestünk olyan GFP-pozitív gyökereket, ahol egyidejüleg a pE2FB::amiRBR vonalra jellemző gyökérfenotípus-változásokat is láttuk (48. ábra). Összehasonlítva a kontroll pDR5-GFP vonalakban látottakkal, a pE2FB::amiRBR vonalban megváltozott a DR5 promóter által irányított GFP szignál. Sok esetben abnormális auxin-felhalmozódás (felerősödött GFP jel) volt 
megfigyelhető a QC környékén (48. ábra C-D) és a merisztéma egyes régióiban (48. ábra B). Ez alapján elmondható, hogy a pE2FB::amiRBR vonal gyökerében az auxin megoszlása eltér a normálistól, sok esetben a sejtekben felhalmozódik az auxin, amely dezorientált sejtosztódást okoz.

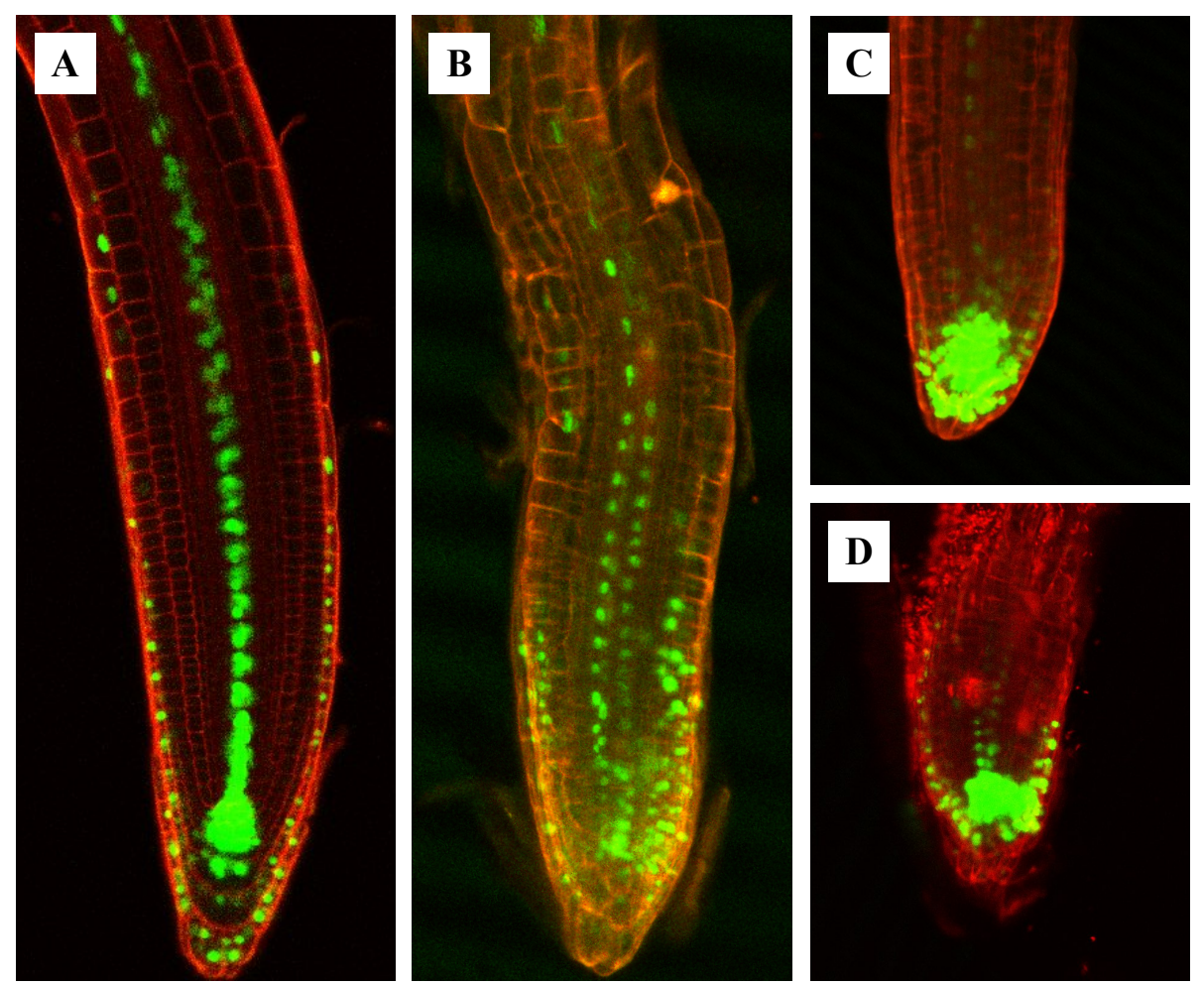

48. ábra. A pE2FB::amiRBR transzgenikus vonal gyökerében az auxin áramlási mintázat eltérést mutatott a vad típushoz képest

Konfokális mikroszkópos kép pDR5-GFP gyökér szignálról A) vad típusú és B-D) pE2FB::amiRBR háttérben. A képen piros jel a propídium-jodid festést, míg a zöld jel a GFP szignált jelzi. A növényeket függőleges lemezen növesztettük, és 7 napos korukban analizáltuk.

A fenti eredmények alapján megváltozott az auxin szint a transzgenikus növényekben, ami az auxin szintézisében és/vagy transzportjában bekövetkezett változásokra utalhat. Kíváncsiak voltunk, vajon az auxin transzportban történt-e mérhető változás. Ennek érdekében egy másik kísérleti megközelítést alkalmaztunk. Ennek során az érett Arabidopsis növények leveleit sejtfalbontó enzimekkel kezeltük, és az így kapott mezofill protoplasztokat tríciummal $\left({ }^{3} \mathrm{H}\right)$ jelölt indol-3-ecetsavval ( ${ }^{3} \mathrm{H}$-IAA)-vel inkubáltuk, majd ezt követően mintákat vettünk, és meghatároztuk a sejtekből az aktív transzporttal kiáramló radioaktív ${ }^{3} \mathrm{H}-\mathrm{IAA}$ mennyiségét. Kontrollként ${ }^{14} \mathrm{C}$-gyel jelölt benzoesavval $\left({ }^{14} \mathrm{C}\right.$-BA) is inkubáltuk a protoplasztokat (49. ábra). A pE2FB::amiRBR vonalból származó protoplasztok csökkent auxin exportot mutattak a kontrollhoz képest, míg a benzoesav transzportjában nem láttunk különbséget. Ez az eredmény arra engedett következtetni, hogy a pE2FB::amiRBR vonalban az auxin transzportja gátlódott. 

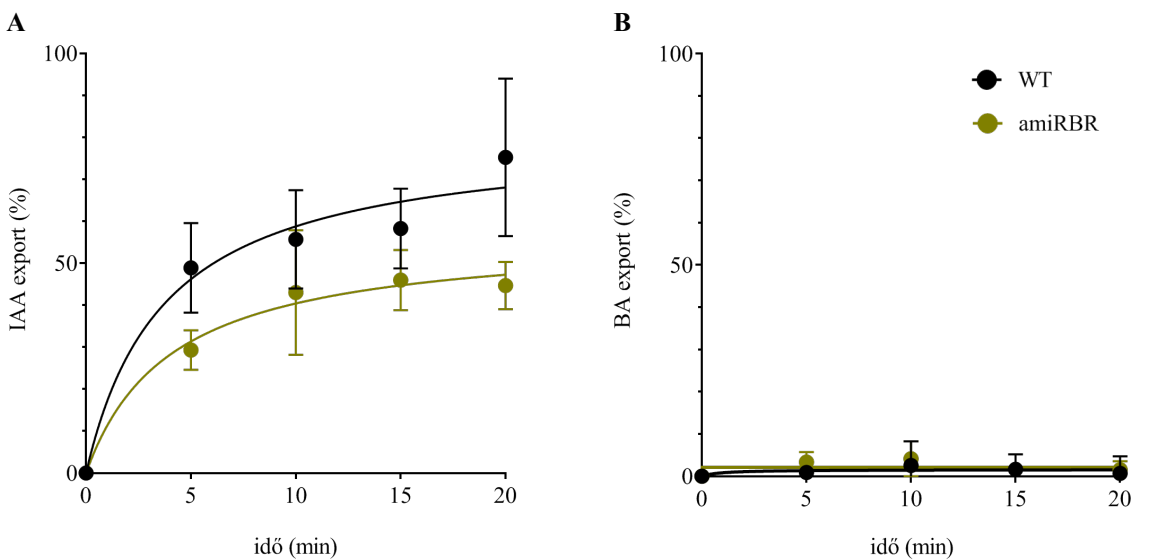

49. ábra. Az auxin export redukálódott a transzgenikus pE2FB::amiRBR növények levelében a vad típusú növényekhez viszonyítva

Tízhetes növények leveléből készített mezofill sejt protoplasztok A) indol-3-ecetsav és B) benzoesav efflux aktivitása (100\%-nak a sejtek által felvett radioaktív auxint és benzoesavat vettük). A benzoesav transzportja más útvonalon történik, mint az indol-3-ecetsavé.

\subsubsection{Kontroll kísérletek}

A fent jellemzett pE2FB::amiRBR vonal egyedi; ehhez hasonló fenotípusú transzgenikus vonalat a többi pE2FB::amiRBR független vonal között nem találtunk (nem bemutatott eredmények alapján). Ezért meg akartunk győződni arról, hogy az itt látott fenotípusos változások valóban az RBR csendesítésének következményei. Ennek érdekében megpróbáltuk helyreállítani a pE2FB::amiRBR vonalunkban látott fejlődési rendellenességeket egy olyan RBR-t expresszáló vonal bekeresztezésével, amely nem tartalmazza a mikroRNS célszekvenciáját (hiányzik belőle a 3' nem transzlálódó szakasz), és így inszenzitív az RBR-re sepcifikus mikroRNS-re (50. ábra). Ebben a transzgenikus vonalban az RBR genomikus klónját a C-terminális végén fuzionáltuk a GFP fehérjével, és a kifejeződését az RBR saját promótere alá vontuk (pgRBR-GFP; Magyar és mtsai., 2012). A pgRBR-GFP funkcionális, mert képes komplementálni az rbrl-2 mutáns növények fenotípusát (helyreállította az ivarsejtképződést; Ingouff, Jullien és Berger, 2006). A keresztezést fertilitási problémák miatt csak az egyik irányba tudtuk kivitelezni, ahol a pE2FB::amiRBR volt az apa, és a pgRBR-GFP volt az anya. A keresztezést követő negyedik generációban (T3) szelektív táptalajon kaptunk olyan vonalat is, ahol a növények mindegyike tartalmazta a pE2FB::amiRBR konstrukciót (homozigóták voltak a transzgénre), de még heterozigóták voltak az RBR-GFP-re (az RBR-GFP-re specifikus norflurazon szelekción még nem mindegyik nőtt). Azon növényekben, amelyek erős pE2FB::amiRBR gyökér fenotípust mutattak (abnormális gyökérsüveg, dezorganizált osztódások a merisztémában), nem detektáltunk GFP jelet (50. ábra A). Azonban találtunk olyan növényeket is, ahol bár gyengén, de már láthattunk RBR-GFP jelet, és a gyökér fenotípusa némileg komplementálódott (a kolumella sejtek már szabályosabban rendeződtek el, 50. ábra B). Végezetül olyan növényeket is megfigyelhettünk, ahol a pE2FB::amiRBR gyökerei a kontroll Arabidopsis gyökerekhez hasonlóak voltak, és itt az RBR-GFP szignál felerősödését tapasztaltuk (50. ábra C). Ez utóbbi 
növényt homozigótának véltük az RBR-GFP transzgénre is. Ez arra engedett következtetni, hogy a pgRBR-GFP képes helyreállítani a pE2FB::amiRBR vonalunk gyökérfenotípusát. A dupla homozigótának vélt növényeink azonban abnormális szegregációt mutattak (nem bemutatott eredmények), így stabil, mindkét transzgénre homozigóta vonalat nem sikerült létrehoznunk.
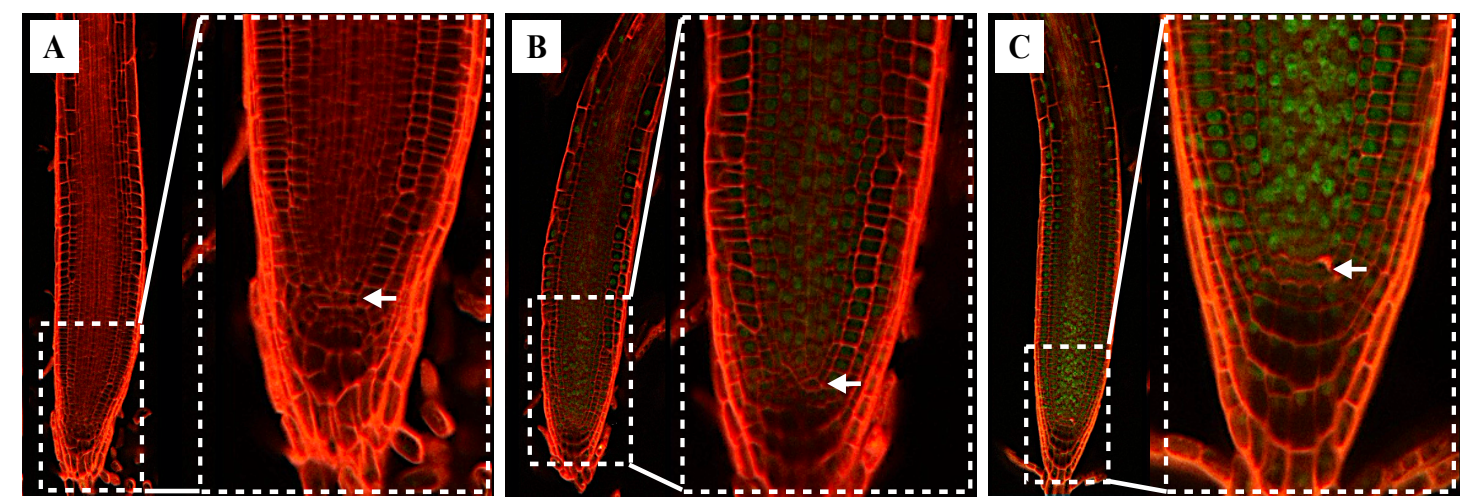

50. ábra. Az RBR-GFP mikroRNS-re inszenzitív változatának a kifejeztetése komplementálta a pE2FB::amiRBR növények gyökérfenotípusát

A T3-as generációban jelen lévő A) pE2FB::amiRBR transzgénre homozigóta növények, amelyek nem tartalmazták a a mikroRNS-re inszenzitív pgRBR-GFP konstrukciót, B) a pE2FB::amiRBR konstrukcióra homozigóta, míg a pgRBR-GFP-re heterozigóta és C) mindkét transzgénre (pE2FB::amiRBR és pgRBR-GFP) homozigóta növények merisztémája és gyökérsüvege propídium-jodid festést követően, 7 napos korban $1 \frac{1}{2}$ GM-en növesztve. A piros szignált a sejtfalba interkalálódó PJ festés okozza, míg a zöld jel a GFP szignál. Az ábrák jobb oldalán látható képek a szaggatott vonallal kiemelt régiók nagyításai. A nyilak a QC pozícióját jelölik.

Meg akartunk győződni arról is, hogy a T-DNS alapú konstrukciónk nem egy génbe épült-e be, amit felelőssé tehetnénk a megfigyelt fenotípusos elváltozásokért. Az inszerció helyének meghatározására TAIL-PCR-t alkalmaztunk (Liu és mtsai., 1995). Ennek során a pE2FB::amiRBR növények genomi DNS-én többlépcsős PCR reakciókat futattunk le, majd a kapott PCR fragmentet (amelynek tartalmaznia kellett a T-DNS szekvencia egy részét és azon DNS szekvenciát, ahova a T-DNS beépült) megszekvenáltattuk. A szekvenálás eredményének elemzése során megállapítottuk, hogy a mikroRNS-t tartalmazó konstrukciónk beépült az Arabidopsis thaliana első kromoszómájában található AP2S génbe (ADAPTOR 55 PROTEIN 2 SMALL SUBUNIT - At1G47830). A beépülés pontos helyét az 51. ábra szemlélteti. Az AP2S gén mutációjáról még nincs kutatási eredmény, de kimutatták, hogy az AP2S fehérje, az ADAPTOR PROTEIN KOMPLEX 2 (AP2) kis alegysége (Happel és mtsai., 2004; Robinson és mtsai., 2014). Az AP2 komplex fontos szerepet játszik a klatrin mediált vezikula transzportban, többek között az auxin transzportjában is (Dhonukshe és mtsai., 2007).

Tehát megállapíthattuk, hogy a pE2FB::amiRBR növényünk egy dupla mutáns (RBR és AP2S), ahol feltehetően a két mutánsra jellemző jellegek együttesen nyilvánulnak meg. Ezek elkülönítése további munka részét képezi. 


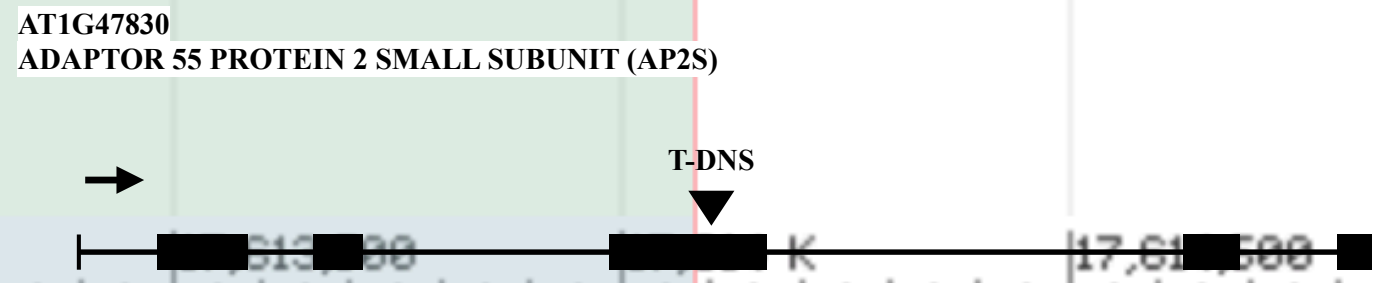

START

51. ábra. A mikroRNS AtAP2S génen belüli lokalizációjának sematikus rajza

A pE2FB::amiRBR mikroRNS konstrukció az Arabidopsis 1-es kromoszóma AP2S gén harmadik exonjába épült be. A fekete téglalapok az exonokat jelölik, míg a vékony vonal az intronokat. Az adatok a TAIRból származnak (The Arabidopsis Information Resource - www. arabidopsis.org)

\subsection{Az E2FB nem transzkripcionális funkciója}

Vizsgálataink alapján az E2FB egyaránt mutat sejtmag- és plazmembrán-lokalizációt (13. ábra A-D, F és 52. ábra A-C). Ugyan ez meglepő, de a növényvilágban nem példa nélküli egyes transzkripciós faktorok plazmamembrán-lokalizációja. Több mint 100 transzkripciós faktor ismert, amely kötődik a membránhoz, ezzel fontos szerepet betöltve a növények fejlödésében (Kim és mtsai., 2006). Vizsgálataink során különböző módszerekkel szerettük volna igazolni az E2FB plazmamembrán-lokalizációját, és választ kapni arra a kérdésre, mi lehet az E2FB plazmamembrán-specifikus funkciója?

\subsubsection{Az E2FB fehérje membrán-lokalizációja}

Az E2FB, mint transzkripciós faktor a különböző növényi szervekben és szövetekben (gyökér, sziklevelek, valódi levelek, embrió) többnyire a sejtmagban lokalizálódik (Leviczky és mtsai., 2019). Azonban az E2FB fehérje nyomon követése során a pgE2FB-3xvYFP vonalban megfigyeltük a plazmamembránhoz asszociálódva is (lásd fentebb 13. ábra A-D, F; illetve lentebb a 52. ábra A-C). Az E2FB legközelebbi rokona, az E2FA fehérje ugyanakkor föleg a sejtmagban lokalizálódott (52. ábra D-F, Mariconti és mtsai., 2002). Ez alapján az E2FB specifikusan kapcsolódik a plazmamembránhoz. Egy korábbi vizsgálat, ahol a plazmamembránhoz asszociálódó fehérjéket vizsgálták tömegspektrometriával, megerősítette az E2FB membrán lokalizációját (Mitra és mtsai., 2009).

$\mathrm{Az}$ E2FB jelenlétét a plazmamembránban biokémiai úton is igazolni akartuk. Ezért plazmamembrán- és plazmamembránhoz asszociálódó fehérjéket tisztítottunk kéthetes, vad típusú, pgE2FB-3xvYFP és pgE2FA-3xvYFP transzgenikus csíranövényekböl. Differenciális centrifugálással elkülönítettük a membránfrakciót más sejtalkotóktól (sejtmag, plasztiszok, mitokondrium, citoplazma), majd anti-GFP ellenanyag segítségével western-blottal vizsgáltuk a membránfrakcióban a GFP-vel jelölt fehérjék jelenlétét (52. ábra G). Az E2FB igen, míg az E2FA nem volt detektálható a membránhoz asszociálódva. 
A membránkötött transzkripciós faktorok (MTF) vizsgálata új kutatási terület a molekuláris biológiában. Az eddigi eredmények azt mutatják, hogy a MTF-ek más fehérjeszerkezettel vannak jelen a sejtmembránban, mint a sejtmagban. Aktiválódásukhoz le kell válniuk a plazmamembránról. Disszociációjuk proteoszómához, vagy specifikus proteázokhoz kötött folyamat. Előfordulhat a fehérje N- vagy C-terminális végének proteolízise, de akár a fehérje belsejében található bizonyos régiók kivágódása is (Vik és Rine, 2000). A tripla Venus YFP-vel fuzionáltatott E2FB fehérje feltételezett mérete (132 kDa) és a fehérje gélen detektálható mérete (180 kDa) eltér egymástól, aminek oka feltehetően a fehérje elsődleges szerkezetét meghatározó aminosav összetételében és/vagy poszttranszlációs változásokban (foszforiláció) keresendő. A pgE2FB-3xvYFP növényekből készített teljes sejtkivonatban több különböző mobilitású E2FB formát is megfigyelhetünk, amelyek keresztreagáltak a GFP antitesttel. Feltehetően ezek különböző E2FB számazékoknak felelnek meg. Azonban az, hogy a különböző formák specifikus funkcióval rendelkeznek-e, egyelőre még nem ismert. Viszont az megfigyelhető, hogy a teljes sejtkivonatban és a membrán frakcióban megtalálható E2FB származékok jelenléte és aránya eltér egymástól.

A jelenlegi kutatások szerint a MTF-ek kihorgonyozódnak a membránhoz, megakadályozva ezzel a sejtmagba történő transzportot. Eddigi ismereteink alapján a membránkötődés fő oka a transzkripciós faktorok gátlása, egyben a gyors mobilizálódás biztosítása, amely a membránhoz kötött proteinek azonnali felszabadulási képességének köszönhető. A sejtnek nem szükséges a transzkripciós folyamatoktól elindítania a fehérjék termelődését, amely időigényes folyamat, elegendő a kész fehérjék aktiválása. Az MTF-ek így fontos szerepet tölthetnek be a jelátvitel útvonalakban (pl. hormonális szignaling) vagy a gyors választ igénylő folyamatok (pl. stresszválasz) esetében (Park és mtsai., 2011; Xie, Han és Shi, 2015). 

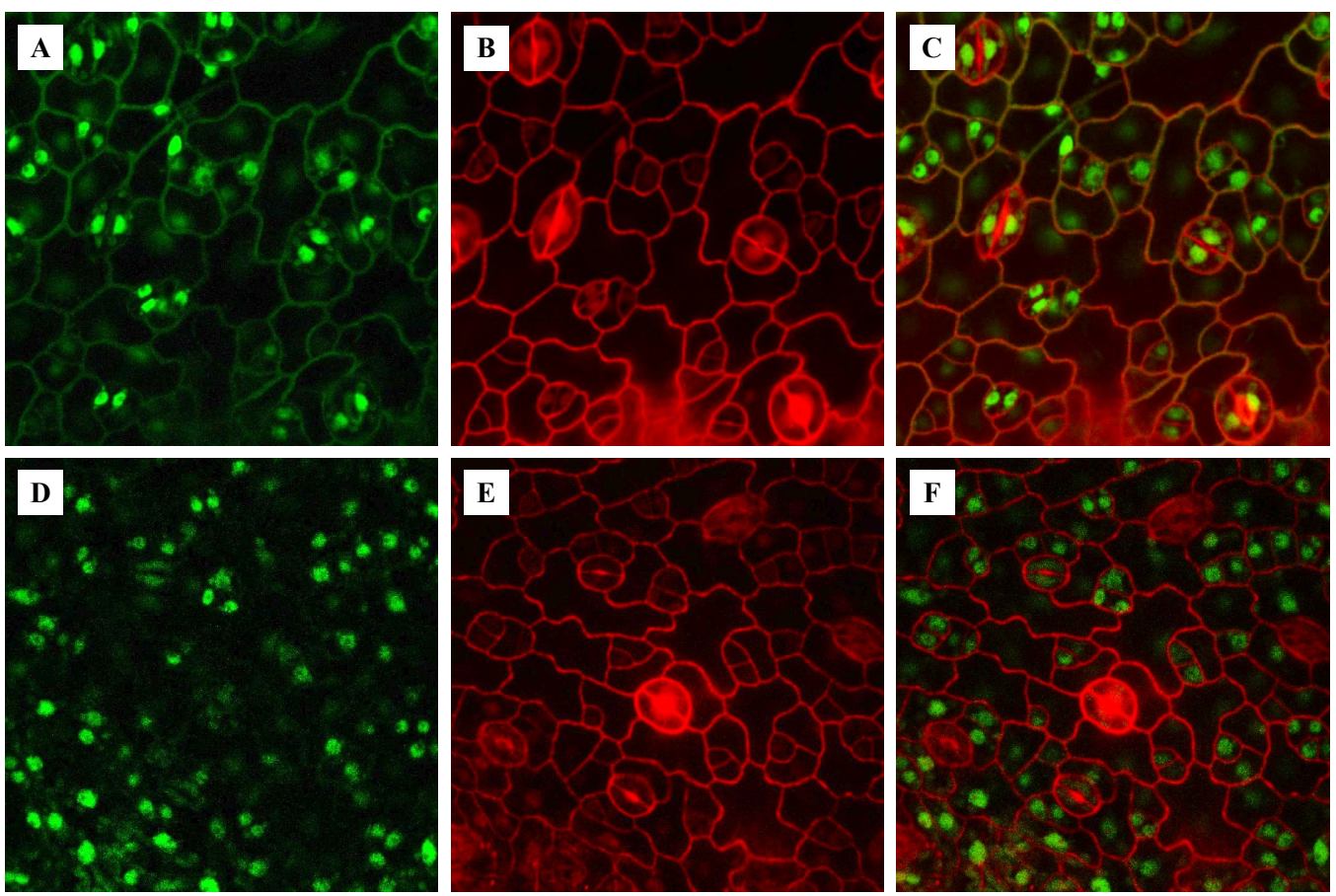

G

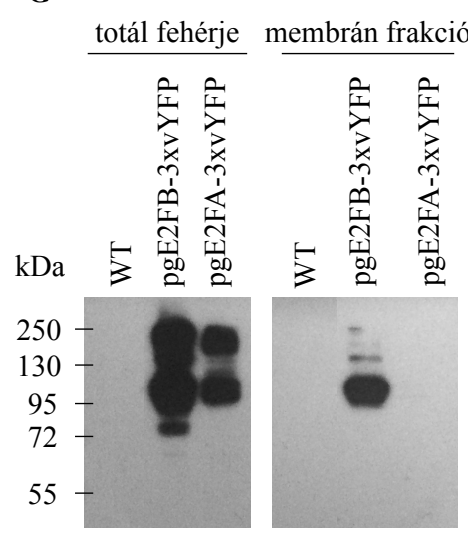

52. ábra. Az E2FB fehérje a sejtmagban és a plazmamembránban is megfigyelhető

Mikroszkópos felvétel A-C) a pgE2FB-3xvYFP növényekről, balról jobbra: E2FB-YFP szignál, propídium-jodid festés, egyesített kép és D-E) kontroll pgE2FA-3xvYFP növények (E2FA-YFP jel, PJ festés, összesített kép). G) Western-blot analízis GFP ellenanyaggal 14 napos, vad típusú pgE2FB-3xvYFP és pgE2FA-3xvYFP növényekböl. A bal oldali kép a feltárt növényi mintát mutatja, ami tartalmaz minden sejtalkotót. A feltárt mintákból differenciális centrifugálással membrán frakciót izoláltunk, amelyet a jobb oldali ábra mutat. Felviteli kontrollként Coommassie festést alkalmaztunk.

\subsubsection{Az E2FB és PIN3 kölcsönhatása, és szerepe az auxin transzportban}

Megállapíthattuk, hogy az E2FB fehérje kötődik a membránhoz. A következőben ezért arra voltunk kíváncsiak, vajon az E2FB fehérje asszociálódik-e membrán- illetve membránhoz kapcsolódó fehérjékhez. Áttekintettük a korábbi E2FB-GFP immunoprecipitálásokat követő tömegspektrometriás analíziseinket, amelyeket pgE2FB-GFP transzgenikus növényeken végeztünk (3. táblázat, Kobayashi és mtsai., 2015a; Kobayashi és mtsai., 2015b; Horvath és mtsai., 2017; Pettkó-Szandtner A, nem közölt eredmények). Az E2FB-vel kölcsönhatásba léptek a jól ismert kölcsönható partnerei (RBR, DPA, DPB, DREAM komponensek) mellett membránasszociált és membrán transzport fehérjék, - köztük a vezikula transzportban szerepet játszó 
membrán fehérjék - az adaptor protein komplexek komponensei, illetve egyes, az auxin transzportban szerepet játszó fehérjék is, mint a PIN3 és a PIN7. Érdeklődésünket ez utóbbiak keltették fel.

\begin{tabular}{|c|c|c|}
\hline \multirow{4}{*}{$\begin{array}{c}\text { Membrán transzportban szerepet játszó } \\
\text { fehérjék }\end{array}$} & At szám & Név \\
\cline { 2 - 3 } & At4G24550 & AP-4M \\
\cline { 2 - 3 } & At5g46630 & AP-2M \\
\cline { 2 - 3 } & At5G39510 & Vesicle transport v-SNARE family protein(SGR4) \\
\cline { 2 - 3 } & At3G60600 & Vesicle associated protein (VAP27-1) \\
\cline { 2 - 3 } & At1G50500 & Membrane trafficking VPS53 family protein(HIT1) \\
\cline { 2 - 3 } & At1G30890 & Integral membrane HRF1 family protein \\
\cline { 2 - 3 } $\begin{array}{c}\text { Auxin transzportban szerepet játszó } \\
\text { fehérjék }\end{array}$ & At3G11130 & CHC1 \\
\cline { 2 - 3 } & At1G23080 & PIN7 \\
\cline { 2 - 3 } & At1G70940 & PIN3 \\
\hline
\end{tabular}

3. táblázat. Az E2FB kölcsönhat többek között membrán-specifikus fehérjékkel is, köztük az auxin transzportban szerepet játszó PIN3 és PIN7 auxin efflux fehérjékkel

A táblázat alapjául tömegspektrometriás adatok szolgálnak, amelyeket különböző korú, és különböző kezelésen átesett pgE2FB-GFP növényekkel végeztünk. A táblázat nem tartalmazza az összes E2FB kölcsönható partnert (Kobayashi és mtsai.; 2015, Horváth és mtsai.; 2017; Pettkó-Szandtner A, nem közölt eredmények).

$\mathrm{Az}$ auxin csatornák fontos szerepet töltenek be az auxin térbeli és időbeli eloszlásában a növényi fejlődés során. A csíranövényben az auxint a sziklevelek, a hajtáscsúcs apikális merisztémája és a hipokotil apikális zónája szintetizálja. Az auxin sejtbe történő bejuttatását - a gyökér irányába történő transzport esetén - az AUX1 influx csatorna végzi. Az auxin sejtből kifelé történő transzportja sebességének fó meghatározói a PIN efflux csatornák (Petrásek és mtsai., 2006). A különböző PIN transzporterek (PIN1-7) a szövetek más-más régióiban expresszálódnak. A vaszkuláris szövetben a sejtből kifelé irányuló auxintranszportot a PIN1 és PIN3 végzi, míg a kéregben (kortex) és a bőrszövetben (epidermisz) a PIN3, PIN4 és PIN7 csatornák irányítják a transzportot. A PIN3 a szállító (vaszkuláris) szövetek körül a hajtás kéreghatár sejtjeiben (endodermisz), a hipokotil kampóban, a gyökér periciklusban és a gyökérsüveg sejtekben expresszálódik. A fehérje a laterális sejtek plazmamembránjában és azok aktin által transzportálódó vezikuláiban fejeződik ki. A PIN3 fontos szerepet tölt be a gravitropikus és fototrópikus válaszreakciókban, és a differenciálódással történő növekedésben, például a hipokotil kampó belső (konkáv) oldalán az auxin maximum kialakításában is részt vesz (Friml és mtsai., 2002; Žádníková és mtsai., 2016).

További kísérletekkel szerettük volna igazolni az E2FB és a PIN3 fehérjék közötti kölcsönhatást. Ennek érdekében GFP-vel fuzionált pgPIN3-GFP transzgenikus növényeket használtunk fel. Ezekből a növényekből GFP affinitás oszloppal fehérje komplexeket izoláltunk, majd immunoblottal megvizsgáltuk, vajon a precipitált komplexek tartalmaznak-e az E2FB fehérjét. A kísérlet eredménye az 53. ábrán látható, amely megerősítette a kölcsönhatást az E2FB és a PIN3 között. 


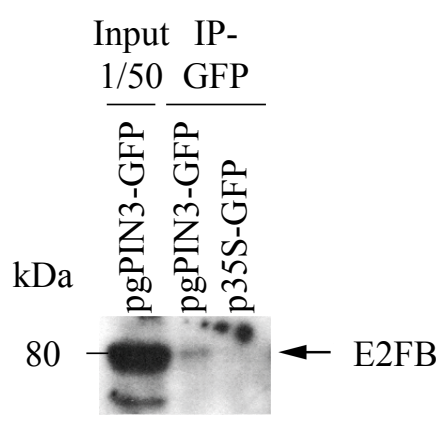

53. ábra. Az E2FB in vivo kölcsönhat a PIN3 auxin efflux fehérjével

Egyhetes PIN3-GFP- (pgPIN3-GFP) és p35S-GFP-termelő transzgenikus növényeket használtunk fel. A fehérje komplexeket immunoprecipitálással (IP) tisztítottuk, anti-GFP ellenanyagot tartalmazó mágnes agaróz gyöngy segítségével. A fehérjemintákat western-blottal vizsgáltuk, amely során specifikus E2FB ellenanyagot használtunk (Magyar és mtsai., 2005). Az IP-hoz használt fehérje mennyiség 1/50-ét használtuk az input mintához.

Kíváncsiak voltunk, melyik régió játszhat szerepet az E2FB membrán-lokalizációjában és a sejten belül hol figyelhető meg az E2FB és a PIN3 együttes jelenléte. Dohányleveleken agroinfiltrációs tranziens transzfekciós kísérleteket végeztünk, ahol a konstrukciókat (p35S:PIN3-RFP, p35S:E2FB-GFP, p35S::E2FB ${ }^{\Delta M B}$-GFP - utóbbi egy E2FB deléciós konstrukció) egyedül, vagy a PIN3 konstrukciót az E2FB-változatokkal külön-külön kombinálva juttattuk be. A deléciós E2FB konstrukcióban deletáltuk az E2FB C-terminális végének egy jelentős részét, és így csak az N-terminális vég maradt intakt, együtt a DNS-kötő, és a dimerizációs doménekkel. Mindhárom konstrukcióban az erős virális p35S promóter irányította a transzgének kifejeződését. A transzformáns dohányleveleket konfokális lézermikroszkóp alatt vizsgáltuk meg. Az E2FB-GFP jelet a sejtmagban és a plazmamembránhoz lokalizálódva is megfigyelhettük, függetlenül attól, hogy a teljes hosszúságú E2FB-t, vagy a csonka változatot fejeztettük ki (54. ábra). Ez alapján feltételezhetően az E2FB membránlokalizációért felelős régiója az E2FB N-terminális részén található. Érdekes módon mindkét E2FB konstrukció esetében meg lehetett figyelni a sejt belsejében egy hálózathoz kapcsolódó GFP jelet, ami alapján az E2FB nemcsak a plazmamembránhoz, hanem belső membránhálózathoz is asszociál. A PIN3és E2FB-kotranszformált dohánysejtekben erős kolokalizációt láthattunk a membránban, és meglepő módon a sejtmagban is (a képeken nyílheggyel jelölve), ami a két fehérje együttes szerepére enged következtetni. Az E2FB és a PIN3 nem csak a plazmamembránban, hanem a citoplazmában található hálózathoz kapcsolódó vezikula-szerü képletekben (a képeken nyíllal jelölve) is kolokalizálódott egymással. 

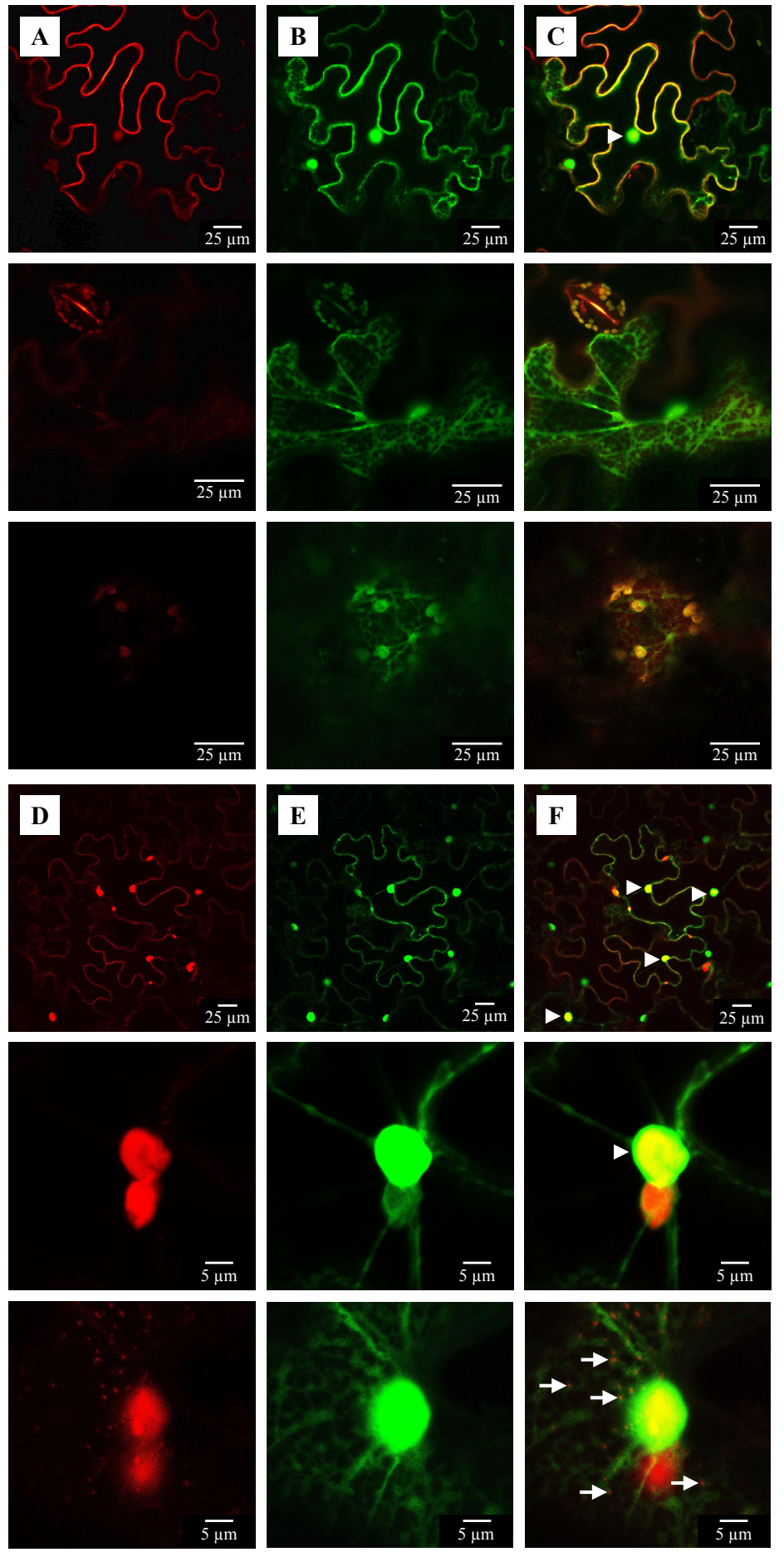

54. ábra. Az E2FB és a PIN3 kolokalizálódik egymással tranziens traszfekciós kísérletekben

Nicotiana benthamiana tranziens levéltranszformánsok konfokális mikroszkópiával készült felvételei A) 35S::PIN3RFP (piros jel), B) 35S::E2FB-GFP (zöld jel) és a C) két fluoreszcensen jelölt protein együtteséről. Az alattuk bemutatott képeken (két egymás alatti sorban), a sejten belüli citoplazmában látható hálózati képletekhez asszociálodó E2FB és PIN3 közös előfordulását figyelhettük meg. Lejjebb, az ábra D) bal oldalán a 35S::PIN3-RFP E), a középső oszlopban a 35S::E2FB ${ }^{\triangle \mathrm{MB}} \mathbf{F}$ ), míg a jobb oldali oszlopban az együttes képek láthatók, ahol az egyes vezikula-szerú képeleteket nyilakkal jelöltük meg. A két protein kolokalizációját a sejtmagban a nyílhegyek jelzik. A képalkotás 4 nappal az agroinfiltrációt követően történt. Méretskála: $25 \mu \mathrm{m}$ és $5 \mu \mathrm{m}$.

A PIN3 az auxin egyik fő transzportfehérjéje. Kíváncsiak voltunk arra, hogy vajon az E2FB szerepet játszhat-e a PIN3 müködésében. Ezért a dohánylevelek előzőekben leírt p35S:PIN3RFP, p35S::E2FB-GFP és p35S::E2FB ${ }^{\triangle M B}$-GFP konstrukciókkal történő transzformációját 
követően megvizsgáltuk, hogyan változik meg a levélsejtek auxin exportja. Ebben a kísérletben a transzformált dohánylevelekböl először mezofill sejt protoplasztokat készítettünk, inkubáltuk öket triciummal $\left({ }^{3} \mathrm{H}\right)$ jelölt 3-indolecetsavval (IAA), majd megmértük a sejtekből aktív transzporttal kiáramló jelölt IAA mennyiségét. Kontrollként a protoplasztokat szén 14-es izotóppal $\left({ }^{14} \mathrm{C}\right)$ jelölt benzoesavval (BA) kezeltük. Ahogyan az várható volt, a p35S::PIN3-RFP transzformált sejtekből erősebb auxin-kiáramlást detektáltunk, mint a kontroll sejtekből (55. ábra). Ezzel szemben az E2FB-vel transzformált sejtekben csökkent a jelölt IAA exportja és meglepő módon hasonló mértékü gátlást láttunk akkor is, amikor a PIN3 az E2FB-vel együtt lett kotranszformálva a dohánylevélbe. Ez alapján feltételezzük, hogy az E2FB gátolja a PIN3 müködését. Hasonló mértékü auxin transzport gátlást lehetett megfigyelni akkor is, amikor a transzaktivációra képtelen deléciós E2FB (p35S::E2FB ${ }^{\triangle \mathrm{MB}}-\mathrm{GFP}$ ) konstrukcióval történt a transzformálás. Ez alapján feltételezzük, hogy az E2FB nem transzkripcionális úton, hanem közvetlenül gátolja a PIN3 müködését.
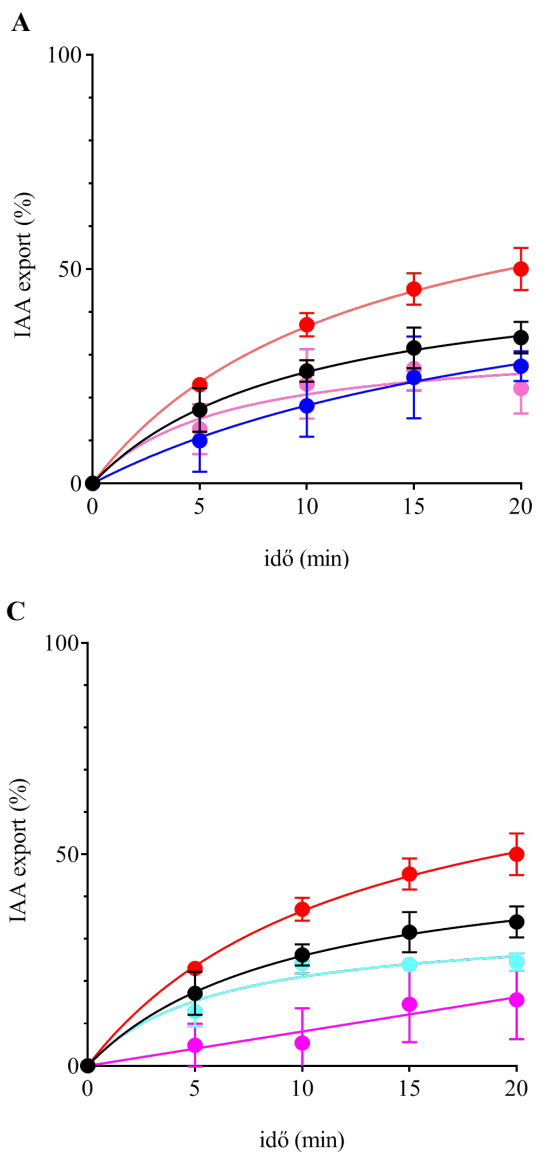

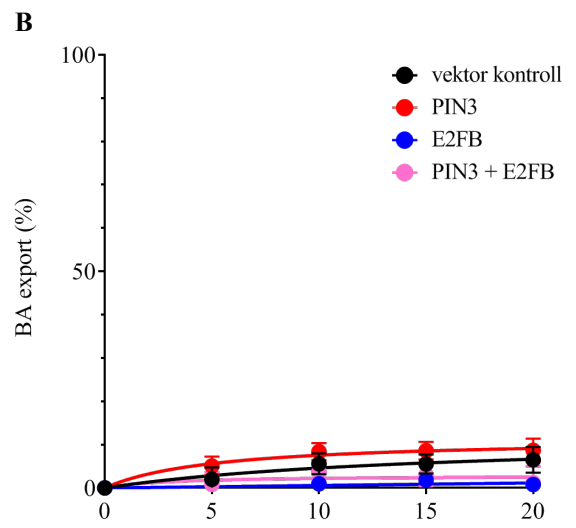

idő (min)

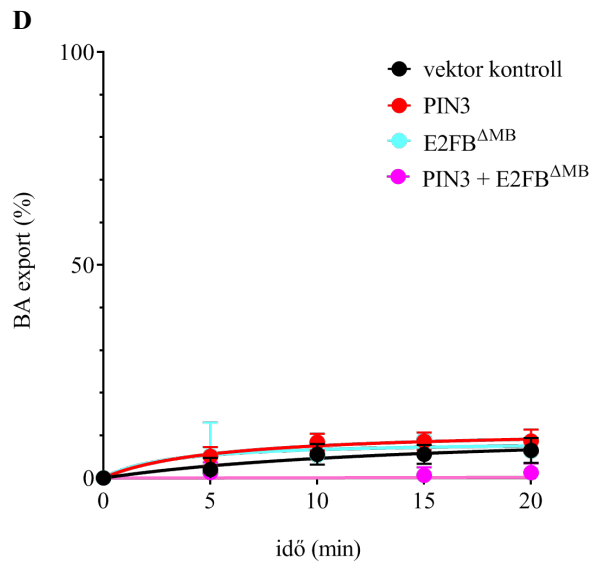

55. ábra. Az E2FB gátolja a PIN3 által stimulált auxin effluxot

Transzformált dohánynövények leveléböl készített mezofill sejt protoplasztok A) és C) indol-3-ecetsav illetve B) és D) benzoesav efflux aktivitásának vizsgálata (100\%-nak a sejtek által felvett radioaktív auxint és benzoesavat vettük). A-B) A növények transzformálása PIN3-RFP-vel, E2FB-GFP-vel külön és együtt történt. C-D) A növényeket PIN3RFP-vel, E2FB ${ }^{\Delta \mathrm{MB}}$-GFP-vel külön és együtt transzformáltuk. Vektor kontrollként RK19 agrobaktérium törzset használtunk a transzformálás során. 
A transzformált dohánylevélben mért auxin transzporthoz hasonló kísérleteket végeztünk el Arabidopsis mutáns növények felhasználásával. Ehhez rendelkezésünkre álltak PIN3 és E2FB génekre különbözö T-DNS inszerciós mutáns vonalak, a pin3-3 (Friml és mtsai., 2002) és a korábban már említett e2fb-1 és $e 2 f b-2$ mutánsok. A mutáns Arabidopsis növényeket üvegházban rövid nappalon talajon neveltük 2 hónapig, és az ép, kifejlett leveleikből mezofill protoplasztokat hoztunk létre, majd jelölt ${ }^{3} \mathrm{H}$-IAA-val és kontrollként ${ }^{14} \mathrm{C}-\mathrm{BA}$-val inkubáltuk őket. Ezt követően különböző időpontokban mintákat vettünk, és megmértük a levélsejtekből kiáramló, jelölt IAA és BA mennyiségét. Közel hasonló mértékủ auxintranszport-csökkenést detektáltunk a pin3-3 és az e2fb-2 mutánsokban, míg az e2fb-1 esetében nem láttunk lényeges különbséget a kontrollhoz képest (56. ábra). Megállapíthatjuk tehát, hogy az e2fb-2 a pin3-3 mutánshoz hasonlóan gátolta az auxin transzportot, míg az e2fb-1 mutánsban a kontrollhoz mért változásokat figyelhettük meg. Ez meglepő eredmény, különösen, hogy a dohánylevélben az e2fb-1 mutánssal gyakorlatilag megegyező $\mathrm{E} 2 \mathrm{FB}^{\triangle \mathrm{MB}}$ túltermeltetése gátolta az auxin transzportot (55. ábra). A különbség oka feltehetően az eltérő expressziós szintekben kereshető, de a pontos választ egyelöre nem tudjuk. Az e2fb-2 mutáns a dimerizációs képességét is elveszítette, így lehetséges, hogy nem, vagy csak moderált mértékben képes a sejtmagba jutni. Korábbi eredmények ugyanis arra engednek következtetni, hogy az E2FB tartósan csak a DPA jelenlétében figyelhető meg a sejtmagban (Kosugi és Ohashi, 2002b). Ez alapján feltételezhető, hogy az E2FB az auxin áramlást nem transzkripcionálisan, a sejtmagban szabályozza. Pontosan nem tudjuk, hogy az E2FB melyik régiója felelös a membrán lokalizációért, és a PIN3 kölcsönhatásért. További kísérletekre van szükség ennek a kérdésnek a megválaszolására.
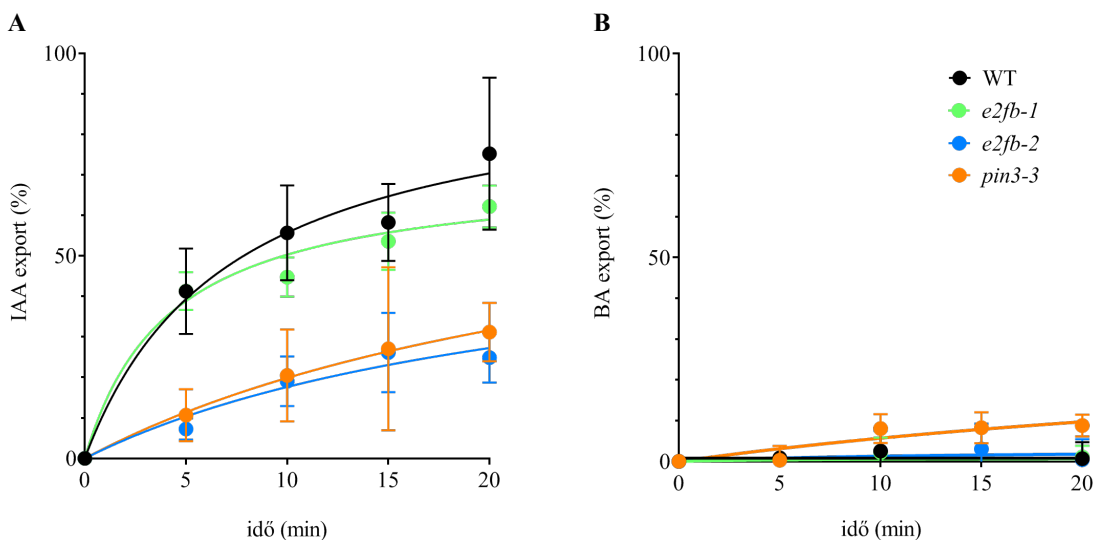

56. ábra. Az E2FB domén-specifikusan gátolhatja az auxin transzportot

Tízhetes növények leveléből készített mezofill sejt protoplaszt A) indol-3-ecetsav és B) benzoesav efflux aktivitása (100\%-nak a sejtek által felvett radioaktív auxint és benzoesavat vettük). A benzoesav transzportja más útvonalon történik, mint az indol-3-ecetsavé, így ez megfelelő kontrollá teszi. 


\section{DISZKUSSZIÓ}

A növények növekedése és fejlődése a merisztéma aktivitásától függ, ám meglepően keveset tudunk arról, hogy egy fejlődő növényi szervben hogyan szabályozódik molekuláris szinten a merisztematikus sejtek osztódása. Meddig osztódhatnak a sejtek, mi az, ami fenntartja az őssejt állapotot, és mi az a molekuláris mechanizmus, ami a már differenciált sejtekben kialakítja és megőrzi a nyugalmi állapotot? Az E2F transzkripciós faktorok - szoros együttmüködésben az RBR-rel - kitüntetett szerepet játszhatnak ezekben a folyamatokban, azonban a pontos mechanizmus még nem teljesen ismert.

A jelenlegi növényi sejtciklus modell szerint az Arabidopsis mindkét aktivátor E2F transzkripciós faktora, az E2FA és az E2FB együttesen felelős a sejtosztódási gének bekapcsolásáért, és ezt a funkciót mindkét esetben az RBR kötődése gátolja (Xiong és mtsai., 2013; Li és mtsai., 2017; Wu és mtsai., 2019). Az RBR inhibitor funkcióját pedig az RBR kinázok (CDK-ciklin) szabályozzák foszforiláció révén. Mindezek alapján az E2FA és E2FB funkciók egymással nagyrészt átfedőek (Wu és mtsai., 2019). Van azonban néhány nyilvánvaló különbség a két aktivátor E2F között, ami arra enged következtetni, hogy az E2FA és az E2FB szerepe nem teljesen egyforma: a) az E2FB a sejtciklus teljes hossza alatt kimutatható, míg az E2FA specifikusan az S fázisban van jelen (Magyar és mtsai., 2000; Magyar és mtsai., 2005; Mariconti és mtsai., 2002), b) Az E2FB túltermeltetése az auxin hiányában is képes sejtosztódást aktiválni, míg az E2FA erre nem képes (Magyar és mtsai., 2005), c) A CYCD3;1-túltermelő Arabidopsis vonalban az RBR nem képes kötődni az E2FB-hez, míg az E2FA továbbra is kimutatható az RBR fehérjéhez kapcsolódva (Magyar és mtsai., 2012), d) Az E2FB kölcsönhat olyan fehérjékkel is, az úgynevezett DREAM komponensekkel - amelyekkel az E2FA nem (Kobayashi és mtsai., 2015; Horvath és mtsai., 2017).

Az E2FB funkcionális jellemzésével kiderítettük, hogy az E2FB szerepe sokkal összetettebb annál, mint azt korábban feltételezték. Megerősítettük, hogy a két aktivátor E2F funkciója sok szempontból különbözik egymástól. Eredményeink rávilágítottak az E2F-RBR kölcsönhatás növényspecifikus sajátosságaira is, illetve az E2FA és E2FB müködésének különleges viszonyára. Mindezek mellett felfedeztük, hogy az E2FB rendelkezik olyan funkcióval is, amely nem a transzkripcionális szabályozásban, hanem az auxin transzportban játszik szerepet.

\subsection{Az E2FB a levélben fejlődési stádiumtól függő módon aktivátor és represszor is lehet}

Korábbi E2FB túltermelési adatok alapján az E2FB a sejtciklus gének aktiválásáért felelős transzkripciós faktor, mely esszenciális a sejtek osztódásba lépéséhez (Magyar és mtsai., 2005; Sozanni és mtsai., 2006; Wu és mtsai., 2020). Az E2FB T-DNS inszerciós mutánsok (e2fb-1, 
e2fb-2) fiatal, még osztódó levelében (8 napos) a sejtciklus gének aktivitása csökkenő tendenciát mutatott, ami megerősítette az E2FB transzkripcionális aktivátor szerepét a sejtosztódás szabályozásában (22. ábra). Az E2FB saját expressziós doménjében történő túltermeltetése azonban meglepö módon csökkentette a levelek méretét, ami egyértelmüen a sejtszám csökkenésének volt köszönhető (16. ábra, Függelék II. táblázat). Különösen a fiatal transzgenikus levelek méretében volt megfigyelhető lényeges különbség a kontrollhoz képest. Hogyan magyarázható, hogy a sejtosztódási gének aktivátora csökkenti a sejtek számát? Az egyik lehetséges magyarázat, hogy az E2FB -túltermelő levélsejtek, bár nagyobb számban léptek be a sejtciklusba, de a G2 és M fázisban rekedtek. Ezzel összhangban a mitotikus CDKB1;1 expressziója megnőtt az E2FB-túltermelö levelekben (18. ábra). A levélsejtek ploidia szintjének meghatározása azonban nem erősítette meg ezt az elképzelést; nem nőtt meg a fiatal levelekben a 4N sejtek aránya, ami jelezné, hogy a sejtek a DNS szintézist követően megálltak volna a G2ben (17. ábra A). Érdekes módon azonban a legerősebben túltermelő vonal (72-es vonal) levelében a G1 sejtek $(2 \mathrm{~N})$ aránya a kontrollhoz képest határozottan megemelkedett, ami arra utal, hogy kevesebb sejt lépett be az osztódásba. A másik lehetséges magyarázat hátterében az RBR áll. Az RBR az E2FB közvetlen szabályozója, a sejtosztódás represszora és potenciális E2F target, hiszen a promóter régiójában több E2F-kötö szekvenciával is rendelkezik (27. ábra). Kimutattuk, hogy az E2FB túltermeltetése fokozta az $R B R$ kifejeződését, és hogy az $R B R$ expresszióját az E2FB közvetlenül, az E2F-kötő szekvenciákon keresztül képes szabályozni (18. ábra, 19. ábra). Az RBR fehérje mennyiségében bekövetkező változás nagyon hasonló mértékü volt az E2FB fehérje mennyiségében megfigyelt emelkedés mértékéhez. A megemelkedett szintü RBR fehérje pedig gyakorlatilag teljes mértékben komplexbe is lépett az E2FB fehérjével, és ez az extra E2FB-RBR komplex nemcsak megakadályozta, hogy a levélsejtek többet osztódjanak a kelleténél, de gátolta is a azok osztódását. Ez egy negatív visszacsatolási mechanizmus, ami általános a homeotikus szabályozásban, mely révén az élőlények képesek önmaguk viszonylagos biológiai állandóságát biztosítani. Az E2FB-RBR komplex a legnagyobb mennyiségben a fiatal levélben formálódott, amely feltehetően gátolta a sejtciklus gének müködését (19. ábra). Az általunk vizsgált sejtciklus géneken ugyanakkor nem láttunk repressziót, sőt, azokban a levélstádiumokban, ahol a kontroll levelekben már egyértelmủ csökkenést lehetett megfigyelni, ott a túltermelő E2FB levelekben továbbra is magas maradt a sejtciklus gének kifejeződése (18. ábra). Hogyan magyarázható ezt az ellentmondás? A levél bőrszöveti sejtek mikroszkópos tanulmányozása során észrevettük, hogy a már megnyúlt, differenciálódó sejtekben új sejtfalak képződnek, ami az osztódás reaktiválódására engedett következtetni. Ez az extra osztódási típus alacsony számban már a 8 napos, fiatal E2FB-GFP-túltermelő levélben is megfigyelhető volt, főleg a levél csúcsához közeledve (ahol a differenciálódás folyamata megkezdődik), de a későbbi levél stádiumban lett igazán karakteres (17. ábra B-C, Függelék II. táblázat). Így a fiatal, még osztódó levélben egyszerre lehetett jelen a represszió, köszönhetően az extra mennyiségü E2FB- 
RBR komplexnek, és a mitotikus reaktiváció, ahol az E2FB felszabadult az RBR gátlása alól. Ez a kettős hatás a korai levélfejlődési stádiumban neutralizálhatta egymást, ami a sejtciklus gének kontrollhoz hasonló expressziós változásaihoz vezetett. Ezek az eredmények ugyanakkor az E2FB két fontos szerepére világítanak rá a levél fejlődése során: a) a fiatal levelekben az E2FB aktiválja a sejtosztódási géneket, de egy negatív visszacsatolás miatt az E2FB aktivitása az RBR szigorú ellenőrzése alatt áll; b) a differenciálódásba lépés során feltehetően az RBR-rel komplexben gátolja a sejtciklus géneket, aminek köszönhetően a sejtek kilépnek az osztódásból, és differenciálódni kezdenek. Az E2FB egy pozitív visszacsatolás révén az RBR-kinázokat is képes közvetlenül aktiválni (CYCD3;1), amelynek köszönhetően az RBR az E2FB-túltermelés mértékétől függően inaktiválódik, és az így felszabadult E2FB aktiválhatja a sejtosztódást (57. ábra A). A CYCD3;1 túltermelésével a sejtosztódás aktivitását a differenciálódás rovására magasan lehet tartani (Dewitte és mtsai., 2003). Az E2FB/DPA ${ }^{\mathrm{OE}}$ a CYCD3;1 túltermeltetéséhez hasonlóan késleltette a differenciálódást a levél fejlődése során, de ez nem eredményezett több levélsejtet (28. ábra, Függelék II. táblázat). Lényeges különbség a CYCD3;1- és az E2FB/DPAtúltermelő levelek között, hogy az utóbbiban jelentős E2FB-RBR komplexformálódást lehetett kimutatni (31. ábra), míg az előzőben az E2FB RBR-mentes, szabad formája volt túlsúlyban (Magyar és mtsai., 2012). Az E2FB-DPA-RBR komplex tehát nemcsak a differenciálódást, de az osztódás folyamatát is lassíthatja. Szinte semmit sem tudunk arról, hogy az E2FB-DPA és E2FBDPB heterodimerek, és ezek RBR-komplexei mennyire hasonló, és milyen eltérő feladatokkal rendelkeznek. A DPA és DPB fehérjék megjelenése a növényi szervekben ugyanakkor nem teljesen egyforma, ami alapján feltételezhetően van különbség a két DP és komplexeik funkciói között.

A növények az állatokkal szemben ellenállnak a rákos sejtburjánzásnak és a tumorképzésnek; ezek a folyamatok sokkal kevésbé veszélyeztetik életképességüket (Doonan és Hunt, 1996). A legtöbb állati daganatos megbetegedésben az aktivátor E2F-ek mennyisége kórosan megemelkedik, és ez döntően hozzájárul a kontrollálatlan sejtosztódások kialakulásához (Chen, Tsai és Leone, 2009). Ezzel szemben az Arabidopsisban az aktivátor E2FB jelentős mértékü túltermelése nem okozott rákos sejtburjánzást. Ennek feltehetően az az oka, hogy az extra E2FB extra RBR-t indukál, és az E2FB-nek ezt az extra aktivitását az RBR sikeresen neutralizálja. Érdekes módon az állatokkal szemben növényekben az RBR - az E2F-ekhez hasonlóan legmagasabb szinten az osztódó, nem pedig a differenciálódó szövetekben és szervekben expresszálódik (Borghi és mtsai., 2010; Magyar és mtsai., 2012). Az E2FB pozitív és negatív visszacsatolási szabályozásokat indukál, ezzel megakadályozva, hogy a sejtszám drámaian megváltozzon a növény fejlödése során. 


\subsection{Az E2FB levélsejttípustól függően aktivátor és represszor is lehet}

A levél börszövetében a zárósejtképződés a merisztemoid sejtvonalból történik (8. ábra). Az már régóta ismert, hogy a merisztemoid sejtek osztódása másképpen szabályozódik, mint a protodermális sejteké, de a pontos molekuláris mechanizmus nem teljesen felderített (Andriankaja és mtsai., 2012). Az e2fb inszerciós mutánsok leveleit nagyobbnak találtuk, mint a kontroll vad típusú leveleket, és ez a megnövekedett levélméret a sejtszám gyarapodásának volt köszönhető (21. ábra A, Függelék II. táblázat). Az embrionális fejlődés során a teljesen kifejlett e2fb mutáns embrió sziklevelében is a sejtszám növekedését figyelhettük meg a kontrollhoz képest (Leviczky és mtsai., 2019). Amikor megvizsgáltuk, hogy milyen méretü sejtek növekedése áll a nagyobb levélméret hátterében, akkor a kisméretü $\left(\leq 60 \mu \mathrm{m}^{2}\right)$ merisztematikus sejtek esetében számottevő növekedést tapasztaltunk (21. ábra B). Az e2fb-2 mutánsban kifejeződő E2FB-GFP (e2fb-2/pgE2GB-GFP) a kontrollhoz hasonló méretü leveleket fejlesztett hasonló celluláris paraméterekkel (e2fb-2/pgE2FB-GFP), ami alátámasztotta, hogy ez egy E2FBspecifikus hatás (21. ábra A-B, Függelék II. táblázat). Mindez arra engedett következtetni, hogy az E2FB szabályozó szerepet játszik a zárósejt merisztemoidok osztódásában is. Hogyan lehet több merisztemoid sejt az e2fb mutáns levelekben? Erre a kérdésre egy másik E2FB mutáns növény jellemzése adta meg a választ, ahol az E2FB-nek egy olyan deléciós származékát fejeztettük ki, amely elveszítette a C-terminális RBR-kötő és transzaktivációs doménjét (p35S::HA-E2FB $\left.{ }^{\triangle R B R} / D P A\right)$. Kétféle hatást láthattunk ezeknek a transzgenikus növényeknek a leveleiben; a fiatal levelek még kevesebb sejtből álltak, mint a kontroll, míg a későbbi levélstádiumokban szignifikánsan megnőtt a sejtek száma (Függelék II. táblázat). A mutáns fiatal levelekben előbb jelentek meg a kontrollhoz képest nagyobb méretủ sejtek (35. ábra G), ami arra utalt, hogy ezek a sejtek korábban léphettek ki az osztódásból. A jelentős sejtszámemelkedés a mutánsok leveleiben elsősorban a kisméretű sejteknek volt tulajdonítható (35. ábra H), és a levél epidermiszben a merisztemoid jellegü, kisméretü sejtek nagyobb csoportjait figyelhettük meg (35. ábra A-F), ami a fokozott osztódási aktivitásukra utalt. A két fenotípus hátterében az E2FB két eltérő szabályozási szerepe állhat: $a$ ) a transzaktiváció, amit az E2 $\mathrm{FB}^{\triangle \mathrm{RBR}}$ mutáns elveszített, és mint domináns negatív E2FB forma gátolhatta a protodermális sejtek osztódását, és $b$ ) az RBRrel történő korepresszió, amelynek elvesztésével deregulálódott a merisztemoidok osztódása (57. ábra). Ez utóbbit támasztotta alá, hogy a sejtciklus gének expressziója megemelkedett a mutáns növények leveleiben (33. ábra B). A hasonló típusú E2FA mutáns túltermeltetése teljesen eltérő levél fenotípust eredményezett (Magyar és mtsai., 2012). Az E2FA ${ }^{\triangle R B R} / D P A$ az endociklust a levélfejlődés korai szakaszában idő előtt bekapcsolta és hiperaktiválta is, míg az E2FB hasonló mutációja az endociklusra nem volt lényeges hatással.

Az E2FB és az RBR közös, merisztemoid osztódást szabályozó funkciójával összhangban az RBR-csendesített növények leveleiben hiperaktiválódott a zárósejt merisztemoidok egyik kulcsszabályozó génje, a TOO MANY MOUTH (TMM). A TMM transzkripciós faktor 
megnövekedett aktivitása fokozza a merisztemoidok osztódását, és a már differenciálódott zárósejtek visszalépését az osztódásba (Borghi és mtsai., 2010; Yang és mtsai., 2014). A csonka E2FB túltermelése során a merisztemoidok fokozott osztódását figyelhettük meg, ugyanakkor nem láttunk olyan zárósejtet, amely visszalépett volna az osztódásba. Ez arra utal, hogy az RBR a merisztemoid osztódást nem az E2FB-vel együttesen szabályozza, hanem valószínűleg más transzkripciós faktorokon keresztül, mint amilyen a FAMA is (Xie és mtsai., 2010). Érdekes módon a SOL1 (PROTEIN TESMIN/TSO1-LIKE CXC 3) és SOL2 (PROTEIN TESMIN/TSO1LIKE CXC 2) transzkripciós faktorok - amelyek az állati LIN54 növényi homológjai (ez az egyik alegysége az állati DREAM multiprotein komplexnek) - szabályozzák a zárósejtvonalban a sejtek sorsát meghatározó osztódásokat (Simmons és mtsai., 2019). Korábbi transzkripciós adatok alapján mind a $S O L 1$, mind pedig a $S O L 2$ expressziós szint megemelkedett az E2FA/DPAtúltermelő növényi vonalban, és a SOL2 az RBR-csendesített növényekben is hiperaktiválódott. Továbbá a SOL2 promóter régiója tartalmaz konszenzus E2F-kötő elemet, mely méginkább potenciális E2F targetté teszi (Borghi és mtsai., 2010). Az E2F-RBR útvonal szabályozhatja ezeket a transzkripciós faktorokat, de a zárósejtvonal szabályozásában betöltött szerepe még nem ismert. Az E2FB-ről kimutatták, hogy részt vesz a növényi DREAM komplexben, amely a sejtciklus G2-M fázisában játszhat szabályozó szerepet (Kobayashi és mtsai., 2015a; Kobayashi és mtsai., 2015b). Az, hogy ez a komplex, vagy ennek a komplexnek egy módosulata részt vesze a zárósejt merisztemoidok osztódásának a szabályozásában, egyelőre még nem ismert.

\subsection{Az E2FB és az E2FA egymást ellentétesen szabályozzák, ami a kompenzációs folyamatok alapja lehet}

$\mathrm{Az}$ e2fb mutánsokban a sejtciklus gének csökkenését lehetett megfigyelni; különösen erős redukciót láttunk a fiatal, még osztódó mutáns levelekben a $C D K B 1 ; 1$ gén kifejeződésében (22. ábra). Érdekes módon azonban sem a CDKB1;1, sem pedig az RBR fehérjék szintje nem változott meg szignifikánsan ebben a levélfejlődési stádiumban (23. ábra). Ez bizonyos fehérje szintü kompenzációs mechanizmus jelenlétére enged következtetni (a fehérjeszintézis, és/vagy fehérje stabilitás szintjén), ami részben magyarázattal szolgálhat arra, miért nem láttunk jelentős sejtosztódási defektust az e2fb mutánsokban. Egyértelmű csökkenést láttunk azonban az RBR foszforilációs szintjében, amit az E2FB-GFP kifejeztetésével kompenzálni lehetett (23. ábra). Az e2fa mutáns csíranövényekben az RBR foszforilációs szint ezzel ellentétesen megemelkedett (24. ábra A). Kiderült, hogy az RBR foszforilációja az E2FA és E2FB fehérjéktől függő módon változik, míg fehérje szinten az E2FA és E2FB egymásra ellentétesen hatnak; az E2FA gátolja az E2FB-t, és az E2FB gátolja az E2FA-t (24. ábra B). Az E2FA aktiválja az RBR-t (az RBR foszforilálatlan formája lesz a domináns RBR forma), míg az E2FB gátolja azt (az RBR foszforilált formája lesz túlsúlyban, 24. ábra C). Az E2FB esetében kimutattuk, hogy 
visszacsatolási mechanizmusok révén pozitívan és negatívan is képes szabályozni az RBR-t, ami stabilitást ad a növekedés rendszerének. Az E2FA túltermelése során is emelkedik az RBR szint, de ezt nem követi emelkedés az RBR foszforilációjában. Korábbi eredményeink alapján az E2FA az RBR-rel komplexben megakadályozza az RBR foszforilációját, ami arra enged következtetni, hogy az E2FA-RBR komplex másképpen szabályozódik, mint az E2FB-RBR komplex (Magyar és mtsai., 2012). Az E2FA-RBR komplex gátolja a differenciálódási gének idő előtti bekapcsolódását. Ezek az eredmények arra engednek következtetni, hogy a két aktivátor E2F egymás funkcióját kompenzálhatja ugyan, de ezt nem egymás funkciójának helyettesítésével érik el, hanem más szabályozási folyamatokon keresztül. Ezzel összhangban az E2FA fehérjét még az E2FB hiányában sem tudtuk kimutatni a mitotikus $C D K B 1 ; 1$ gén promóteréhez asszociálódva (26. ábra). Ez a szabályozás hasonlít a Drosophila dE2F1 és dE2F2 müködésére; a represszor dE2F2 az RBF1-2 fehérjéivel komplexben elsősorban differenciálódási géneket szabályoz, míg az E2FB müködésében az aktivátor dE2F1-hez hasonlít jobban (Frolov és mtsai., 2001; Dimova és Dyson, 2005).

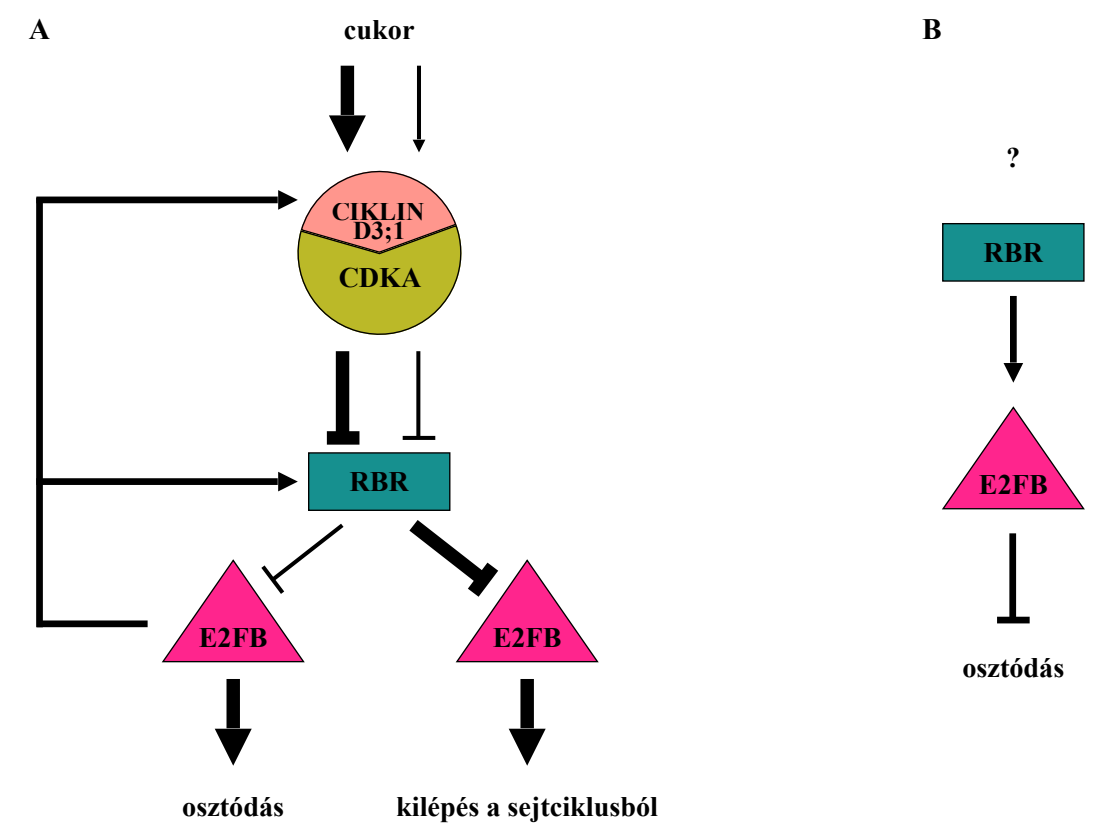

57. ábra. Az E2FB funkcióit leíró szabályozási modell a levélfejlődés során

Az E2FB három eltérő aktivitással rendelkezik. A) Ezek különböző levélfejlődési szakaszokban vagy B) különböző sejttípusokban dominálnak. A) Az aktiv E2FB RBR-mentes formában van jelen, föleg az osztódó sejtekből álló fiatal levelekben. A fiatal osztódó levél tápanyagokban gazdag szövet, ahol az E2FB felszabadul az RBR gátlása alól a CIKLIN D3;1 - CDKA kináz által, amely cukor hatására aktiválódik és foszforilálja az RBR-t (bal oldali útvonal). Az aktív E2FB visszacsatolási mechanizmusok révén aktiválja saját szabályozói, az RBR és a CIKLIN D3;1 expresszióját egyaránt. Ez az autoregulációs szabályozás stabilizálja a rendszert. Azokban a növényi sejtekben, ahol a növekedési szignál gyengébb (jobb oldali útvonal), az E2FB és az RBR szintje egyaránt csökken, és az RBR aktívabbá válik (kevésbé foszforilálódik), ami az E2FB kötéséhez és gátlásához vezet. Ez a gátlás fontos szerepet játszik a nyugalmi állapot kialakulásában a differenciálódás irányába elkötelezett levélsejtekben. B) A fejlödő levelekben az E2FB represszor komplexet képez az RBR-rel a zárósejt merisztemoidokban, hogy kontrollálja az osztódásukat. Nem ismerjük azonban, hogy hogyan, milyen szignálok által szabályozódik ez az útvonal. 


\subsection{Az E2FB szerepe az auxin transzportban}

Az eredményeink alapján az E2FB transzkripcionális szerepe az RBR szigorú kontrollja alatt áll. Megpróbáltuk ezt a szabályozást egy mesterséges mikroRNS segítségével elrontani. A mikroRNS-ek a kis, nem kódoló RNS-ek egy csoportja (18-28 nukleotid hosszúságúak). Legfontosabb szerepük a fehérje expresszió poszttranszkripciós szabályozásában van, de kimutatták szerepüket normál (pl. sejtosztódás, apoptózis), és patológiás sejtfolyamatokban is. Daganatokban egyeseket onkogénként, míg másokat tumorszupresszorként azonosítottak (Tanase, Ogrezeanu és Badiu, 2012). Befolyásolhatják a génexpressziót, beleértve a promóter aktivitását, az mRNS-ek stabilitását, és a transzlációs hatékonyságot is (Schwab és mtsai., 2006). Így létrehoztunk egy olyan transzgenikus vonalat, amelyben egy RBR-re specifikus mikroRNS-t az E2FB kifejeződésért felelős promóter szakasz ellenőrzése alá vontunk (pE2FB::amiRBR). Ebben a mutánsban feltételezhetően az E2FB expresszáló sejtekben gátlódik az RBR funkciója. Azonosítottunk egy olyan transzgenikus vonalat, ahol a már jól ismert RBR-csendesítésre jellemző fenotípusos elváltozások mellett (generálisan kisebb növények, kisebb szervekkel, parciális sterilitás, lefelé pöndörödő levelek, 38. ábra), megjelentek olyan új rendellenességek, amelyeket korábban az auxin jelátviteli mutánsokban figyelhettünk meg (abnormális embriók, gyökérnövekedési anomáliák, parciális defektus a gyökerek gravitropikus növekedésében, phyllotaxis problémák, 39-43. ábra). A mutáns növényünkben igazoltuk, hogy a) RBR-specifikus mikroRNS termelődött (37. ábra A), b) az RBR fehérje szinten redukálódott, és kevesebb E2FBRBR komplex jött létre (37. ábra B), c) a mikroRNS-re érzéketlen RBR-GFP-nek a pE2FB::amiRBR mutánsban történő kifejeztetésével tranziensen kompenzálni tudtuk a gyökér fenotípusát (50. ábra). A későbbi vizsgálataink azonban azt is kiderítették, hogy az amiRBR konstrukció egy másik gén kódoló szekvenciájába épült be (51. ábra). Ez a gén az ADAPTOR 55 PROTEIN 2 SMALL SUBUNIT (At1G47830, röviden AP2S), amely az Arabidopsis thaliana 1-es kromoszómáján lokalizálódik. Tehát megállapíthatjuk, hogy a pE2FB::amiRBR növényünk egy dupla mutáns, ahol együtt láthatóak a két mutánsra jellemző jellegek, és ezek elkülönítése további munka részét képezi. Ezt nehezíti az is, hogy az AP2S pontos funkciója kevésbé ismert, azonban kimutatták, hogy részt vesz a növényi ADAPTOR PROTEIN (AP) komplexben. Az ADAPTOR PROTEIN (AP) komplexek heterotetramerek, amelyek két nagy $(\alpha, \beta)$, egy közepes $(\mu)$ és egy kis alegységet $(\sigma)$ tartalmaznak. Öt típusukat különböztethetjük meg (AP1-5), amelyek különböző szabályozási útvonalakban játszanak szerepet. Az eukarióta szervezetek nagy részében megtalálhatóak, úgy, mint élesztő, fonalféreg, emlős (Robinson és mtsai., 2014), beleértve a növényeket, így az Arabidopsis thalianat is (Bassham és mtsai., 2008; Hirst és mtsai., 2011). Állatokban az AP1 a transz-Golgi és endoszóma közötti forgalomban (Hirst és mtsai., 2012), az AP2 a klatrin-mediált endocitózisban (McMahon és Boucrot, 2011), az AP3 a transz-Golgi hálózatból/endoszómából a vakuolumba/lizoszómába irányuló fehérje forgalomban (Dell’Angelica, 2009) vesz részt. Az AP4 specifikus cargo proteineknek (mint az amiloid 
prekurzor fehérje) a transz-Golgiból az endoszómába történő transzportjában (Burgos és mtsai., 2010), az AP5 pedig a kései endoszómában játszik fontos szerepet (Hirst és mtsai., 2011). Az AP komplexek növényekben is nagyon hasonló funkciókat töltenek be. Elsősorban transzport folyamatokban és jelátviteli utakban vesznek részt, azonban szerepük még nem teljesen ismert (Yamaoka és mtsai., 2013).

Az AP2S az AP2 komplex kis alegysége. Az Arabidopsisban az AP2 kölcsönhat a vacuolar sorting receptorokkal (Happel és mtsai., 2004), és szerepet játszik a klatrin mediált endocitózisban is. Ezáltal befolyásolja a PIN-FORMED (PIN) auxin transzportereket, a PLASMA MEMBRANE INTRINSIC PROTEIN 2 víz csatornákat (Dhonukshe és mtsai., 2007), egyes vas transzportereket - mint az IRON-REGULATED TRANSPORTER 1 - (Barberon és mtsai., 2011), a növény-specifikus endocitotikus SNARE VESICLE-ASSOCIATED MEMBRANE PROTEIN 727-et (Ebine és mtsai., 2011), és a BRASSINOSTEROID INSENSITIVE 1 ligand aktivált brasszinoszteroid receptorokat is (Irani és mtsai., 2012; Yamaoka és mtsai., 2013).

Az AP2S mutánsok jellemzése még nem történt ugyan meg, de az AP2 komplex $\mu$ alegység mutánsa (ap2m) mutat némi hasonlóságot a pE2FB::amiRBR vonalunk fenotípusával, bár sokkal kevésbé drasztikusat. Ezek a kisebb rozetta levelek rövidebb petiollal, alacsony fertilitás, zárt állású sziromlevelek (be nem mutatott eredmények) és kisebb maghozam (58. ábra; Yamaoka és mtsai., 2013).
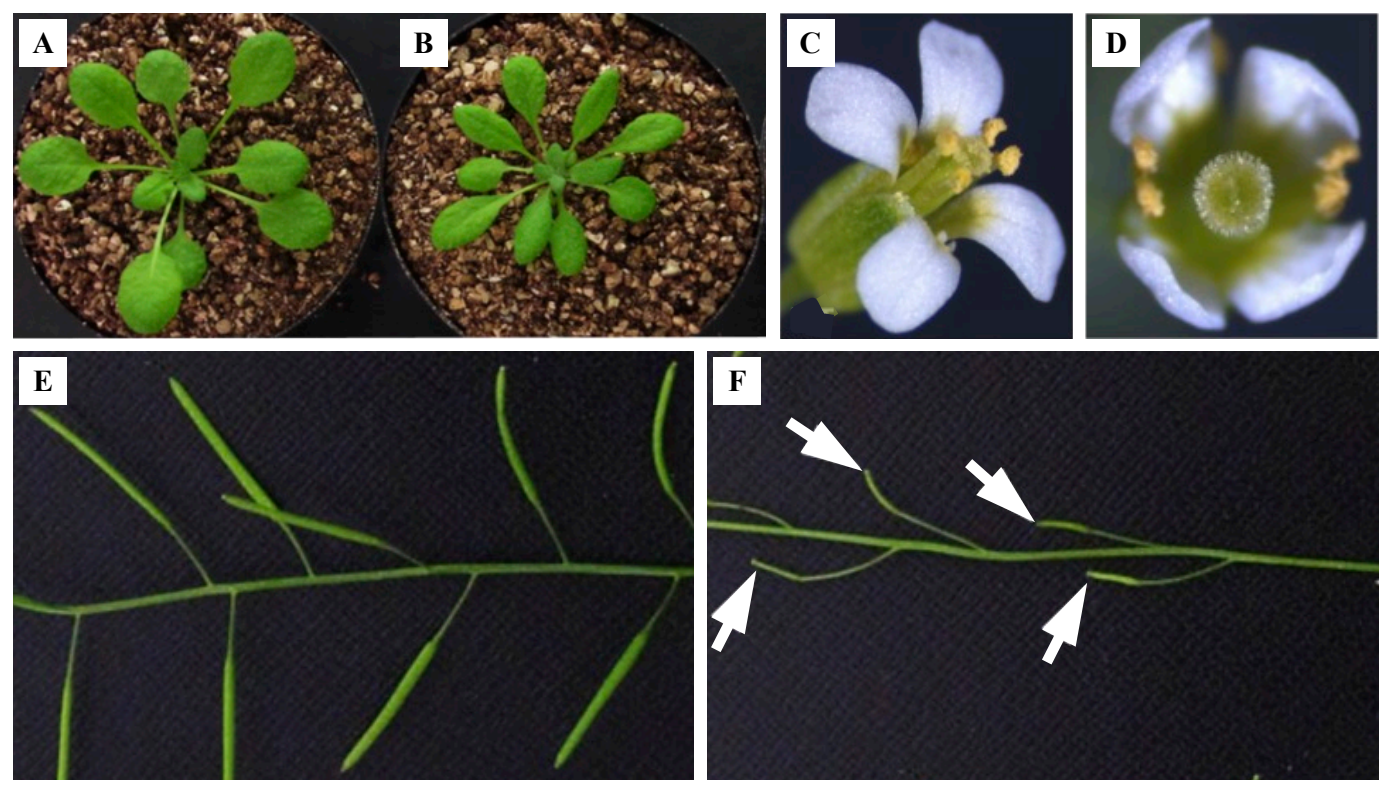

58. ábra. Az ap2m mutáns növények fenotípusa

A négyhetes, talajon növesztett A) vad típusú növényekhez viszonyítva az B) ap $2 m$ növények kisebb méretüek. C) A vad típusú növényekhez képest az D) ap $2 m$ növények sziromlevelei zártabb állásban helyezkednek el. A F) mutáns növények fertilitása alacsonyabb, a megtermékenyülés hiányában sok esetben kisebb becőkkel rendelkeznek (nyíllal jelölve), mint a E) vad típusú kontroll (Yamaoka és mtsai., 2013). 
Az AP2 komplex különböző alegységei természetesen még más folyamatokban is fontos szerepet játszhatnak az AP2 komplexben való részvételen kívül. A komplex egyes elemeinek a fontossága a különböző folyamatokban is eltérö lehet.

A PIN-FORMED auxin transzporterek dinamikus reciklizációja a plazmamembrán és az endoszómális kompartmentek között, amely a PIN-ek polarizációjának előfeltétele, klatrin mediált módon történik (Dhonukshe és mtsai., 2007; Dhonukshe és mtsai., 2008; Laxmi és mtsai., 2013). Ez a megállapítás azért jelentős, mert az AP2 komplex és a KLATRIN NEHÉZLÁNC FEHÉRJE (CLATHRIN HEAVY CHAIN röviden: CHC - a klatrin burkolt vezikulák egyik komponense) között kapcsolat áll fenn (Yamaoka és mtsai., 2013). A pE2FB::amiRBR mutáns auxin-jelátviteli fenotípusai chc funkcióvesztéses és domináns negatív CHC1 (HUB) transzgenikus mutánsokban egyaránt megjelennek. A chc növények olyan különböző morfológiai zavarokkal rendelkeznek, amelyek az auxin mutánsokat (gnom és pin) és az auxin transzport inhibitorral kezelt növényeket jellemzik (Friml és mtsai., 2003; Benková és mtsai., 2003; Geldner és mtsai., 2004). Ezen felül agravitropikus gyökérnövekedést, a kolumella réteg dezorganizációját, a gyökér merisztémában abnormális irányú osztódásokat, és a sziklevelek számának és pozíciójának változását épp úgy mutatják, mint a pE2FB::amiRBR növények (59. ábra; Kitakura és mtsai., 2011).
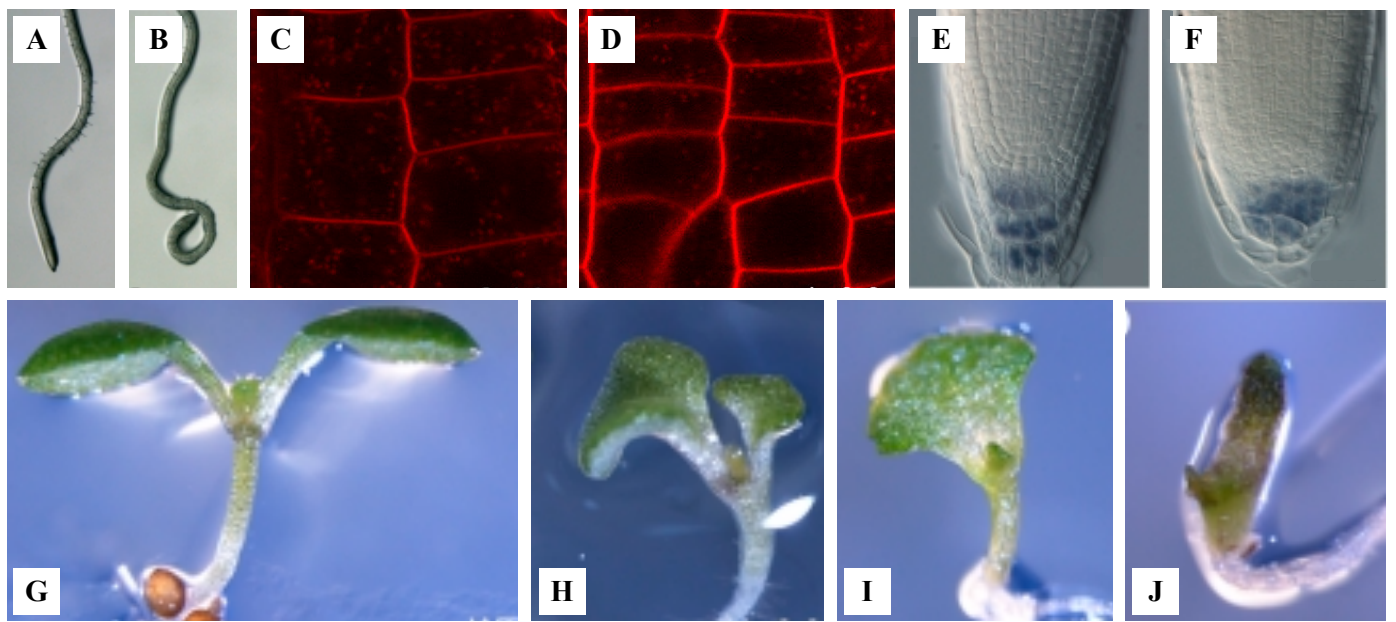

59. ábra. A klatrin nehézlánc (chc2-2) és a domináns negatív CHC1 (HUB) mutánsok jellegzetes fenotípusa nagyon hasonló a pE2FB::amiRBR vonal fenotípusához

Négynapos A) kontroll és B) HUB indukálható domináns negatív transzgenikus vonal gyökérnövekedése 2 nappal a transzfert követően 4-hidroxitamoxifen tartalmú táptalajra. C) vad típusú és D) abnormális osztódási iránnyal rendelkező $c h c 2-2$ mutánsok gyökér merisztéma részlete propídium-jodid festést követően. Tíznapos E) vad típusú és F) chc2-2 mutánsok Lugol festést követően. A mutáns vonal kolumella sejtjei nagy mértékü dezorganizációt mutatnak. Tíznapos G) WT és H-J) abnormális kotiledon fejlődést és szerveződést mutató chc2-2 növények (Kitakura és mtsai., 2011).

A fent említett fenotípusok nagyon hasonlóak a pE2FB::amiRBR transzgenikus vonalban megfigyelt elváltozásokhoz. Azonban nem tudjuk, hogy az AP2 komplex kis alegysége milyen funkciót tölthet be a klatrin mediált endocitózisban, akár önállóan vagy más fehérjékkel komplexben. Ennek a kérdésnek az eldöntésére az AP2S génre mutáns T-DNS inszerciós vonalak (SAIL_245_C03.v1, SALK_092630.43.80.x) jellemzésébe fogtunk bele. Jelen pillanatban nem 
zárható ki az sem, hogy a pE2FB::amiRBR hatás és az AP2S mutáció együttesen vezet a megfigyelt rendellenességekhez. Tömegspektrometriai adatok igazolják az RBR kötődését különböző, vezikula transzportban szerepet játszó fehérjékhez, mint amilyen a MYOSIN 1, vagy a membránszerveződésben szerepet játszó fehérjék: a PAPD-LIKE SUPERFAMILY PROTEIN, a CDH7B (CADHERIN 7B) és egy ATP függő cink metalloproteáz, az FTSH12 (Magyar Z és Pettkó-Szandtner A, nem publikált eredményei alapján). A fenotípusos elváltozás hátterének felderítése érdekében keresztezni kívánjuk az ap $2 s$ mutáns növényeket a p35S::amiRBR vonallal (Horvath és mtsai., 2017). Érdekes módon az E2FB kölcsönható fehérjéi között megtaláltuk az AP2 komplex $\alpha$ alegységét (3. táblázat), ami arra enged következtetni, hogy az E2FB fehérje részt vehet az AP2 komplexben. Ezzel összhangban a HA-E2FB ${ }^{\triangle R B R}$ mutáns konstitutív kifejeztetésével abnormális szervfejlődést figyelhettünk meg, ami alapján az E2FB szabályozhatja az auxin irányította morfogenezist is. Vajon ez a szabályozás transzkripcionális, melyben az E2FB a folyamatban részt vevő szabályozó géneket regulálja, vagy az E2FB részt vesz más szabályozási folyamatokban is? Erre a kérdésre a választ még nem tudjuk. Az E2FB fehérjét ugyanakkor megfigyelhettük nemcsak a sejtmagban, de a membránhoz asszociálódva is. Az E2FB membránspecifikus kapcsolódását több megfigyelés is alátámasztotta: a) az E2FB3xvYFP és az E2FA-3xvYFP közül csak az E2FB szignál asszociálódott a sejtmembránhoz, amit biokémiai módszerrel is igazolni tudtunk, b) a plazmamembránhoz kapcsolódó fehérjék között azonosították az E2FB fehérjét (Mitra és mtsai., 2009), c) az E2FB-GFP-hez kapcsolódó fehérjék között membránfehérjék is előfordultak; a vezikula transzportban szerepet játszó fehérjék mellett az auxin transzport szabályozásában részt vevő PIN fehérjéket is azonosítottunk (PIN3 és PIN7). Kölcsönhatási és kolokalizációs kísérletekkel megerősítettük, hogy a PIN3 és az E2FB fehérjék egymással in vivo kölcsönhatnak, és a plazmamembránban együtt jelennek meg (53. ábra, 54. ábra, 3. táblázat). A tranziens dohánylevél-transzfekciós kísérletekkel kimutattuk, hogy az E2FB gátolja a PIN3 által stimulált auxin transzportot (55. ábra A-B). Erre a gátlásra az E2FB deléciós mutánsa is képes volt, amelyikről eltávolítottuk a C-terminális transzaktivációs domént, együtt az RBR-kötő doménnel és a Marked box szekvenciával (55. ábra C-D). Ez az eredmény egyrészt arra enged következtetni, hogy az E2FB nem transzkripciós faktorként szabályozza a PIN3 müködését, másrészt arra utal, hogy az E2FB N-terminális része szerepet játszhat a membrán lokalizációban és a PIN3 kölcsönhatásban. A két aktivátor E2F közül csak az E2FB kötődik a membránhoz (52. ábra). Az E2FA és az E2FB közötti különbség a kezdeti N-terminális szakaszra korlátozódik, ezért feltételezzük, hogy ez játszhat szerepet a membrán lokalizációban (3. ábra). Arabidopsis e2fb mutánsokban is megvizsgáltuk, hogyan változik meg az auxin transzport a levél protoplasztokban a kontroll vad típusú levélsejtekhez képest (56. ábra). Az e2fb-1 mutáns a kontrollhoz volt hasonló, míg az e2fb-2 mutánsban jelentős gátlást lehetett megfigyelni az auxin traszportban. Ez az eredmény megerősíti, hogy a T-DNS inszerciós e2fb mutánsok különböző funkciókat veszíthettek el. Az e2fb-2, szemben az e2fb-l-vel, a dimerizációs képességét is 
elveszíthette, ezért feltételezzük, hogy nemcsak a DNS-kötő aktivitása csökkent, de a sejtmagba történő transzportja is sérülhetett (Kosugi és Ohashi, 2002b). A membrán lokalizációért felelős E2FB szekvenciát az N-terminális részre prediktáljuk, és az e2fb-2 mutáns ezt a funkcióját megőrizhette, de elveszítette a nukleáris, DNS-kötő szerepét. Van-e valamilyen hatása az E2FBRBR szabályozásnak az auxin transzportban szerepet játszó génekre? Érdekes módon az RBR kötődését figyelték meg számos auxin szignálban központi szerepet játszó génhez - köztük található a PIN3 és PIN4 is, valamint az auxin influx AUX1, - de az RBR szabályozhatja a TIR1 (TRANSPORT INHIBITOR RESPONSE1) auxin receptor müködését is (Bouyer és mtsai., 2018). Hogyan kapcsolódik az E2FB membrán funkciója a nukleáris funkcióhoz? Hogyan szabályozza az RBR ezeket? Van-e közvetlen hatása az E2FB membránspecifikus funkciójára? Hogyan változik meg az auxin szintje a sejtekben, ha elrontjuk az E2FB auxin transzport szabályozó funkcióját? Melyek azok a sejtek, ahol az E2FB auxin transzportot szabályozó funkciója szerepet játszik? Ezekre, és még számtalan más izgalmas kérdésre egyelöre még nem tudjuk a választ. Az eddigi eredményeink alapján az alábbi modellt állítottuk fel (60. ábra).

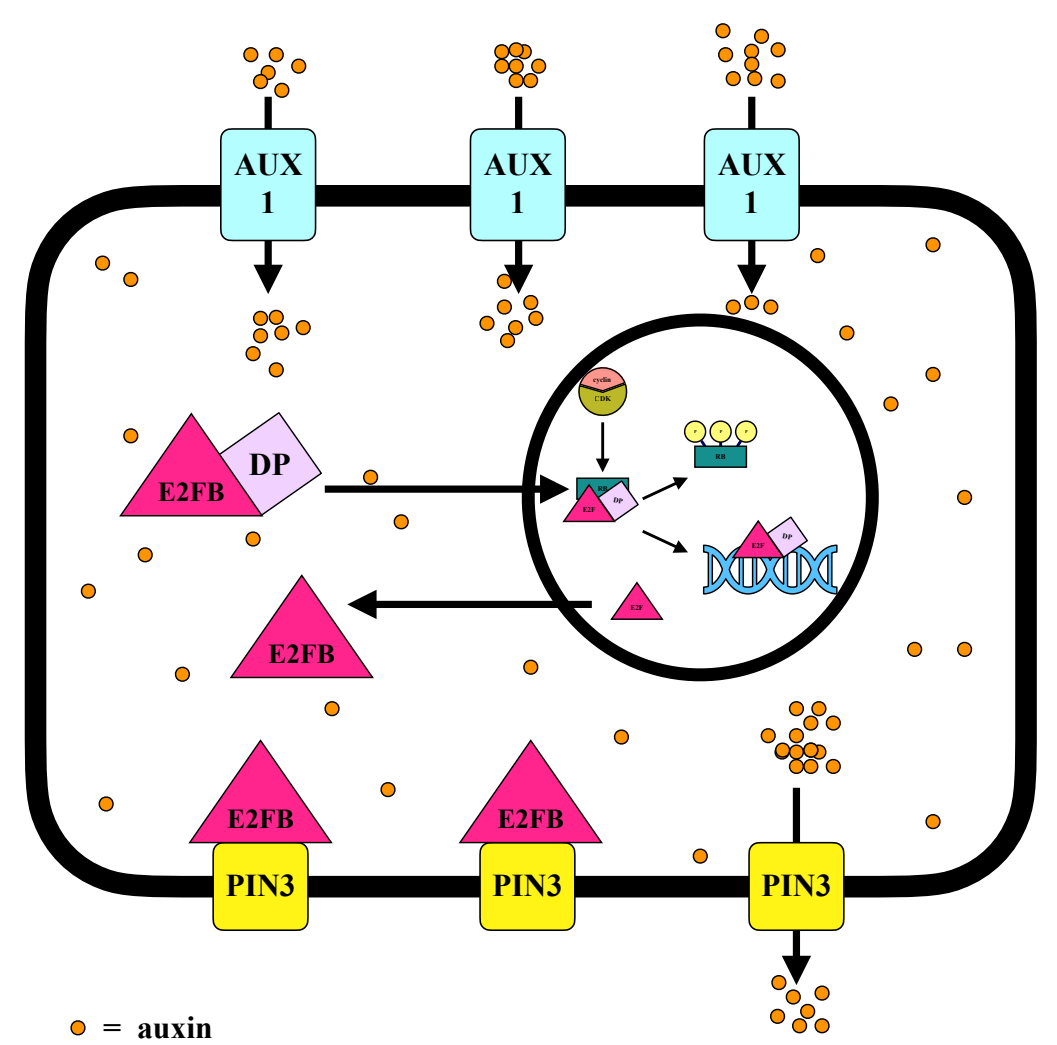

60. ábra. Az E2FB szerepe az auxin transzport szabályozásában

Az auxin aktiválja a sejtosztódást, és az RBR kináz formálódását (CIKLIN D3;1-CDKA;1). Az aktív CDK által foszforilált RBR szabadon engedi az E2FB-t, a sejtciklus gének aktiválódnak, és a CDK az $\mathrm{S}$ fázist követően foszforilálhatja a DP partnert is. Az E2FB monomer, RBR és DP nélküli formája kiáramlik a sejtmagból, és a PIN3 auxin efflux csatornákhoz kötődve megakadályozza az auxin kiáramlását a sejtből, aminek köszönhetően a sejten belüli auxin szint megemelkedik. A megnövekedett auxin szint serkentheti a DP fehérjék szintézisét, és a DPA E2FBhez történő dimerizációját. A DP dimerizáció csökkenti az E2FB sejtmagon kívüli mennyiségét. Az E2FB szint emelkedése az RBR szint emelkedéséhez is vezet, aminek köszönhetően gátlódhat a sejtosztódás, és az E2FB fehérje szintje is, ami az auxin szint csökkenéséhez vezet. 


\section{KÖSZÖNETNYILVÁNÍTÁS}

Ezúton szeretném megragadni az alkalmat, hogy megköszönjem és kifejezzem hálámat mindazoknak, akik munkámban segítettek és mellettem álltak az évek során.

Elsőként szeretnék köszönetet mondani témavezetőmnek, Dr. Magyar Zoltánnak, laboratóriumunk vezetőjének, aki szakmai előmenetelemet az elmúlt 8 évben támogatta és tanácsaival segítette. Áldozatos munkája, rugalmassága és naprakészsége nélkül nem születhetett volna meg ez a dolgozat.

Szeretném külön megköszönni Dr. Molnár Eszternek, hogy egyszerre volt barát és munkatárs. Hasznos tanácsaival és szakértelmével nagymértékben hozzásegített a molekuláris módszerek elsajátításához és kreatív ötleteivel a legösszetettebb feladatot is képesek voltunk megoldani.

Hálás vagyok Dr. Pettkó-Szandtner Aladárnak, aki MS analíziseivel segítette az E2FB kölcsönható partnerek feltérképezését, ezáltal az E2FB funkcióinak mélyebb megismerését.

Köszönetet szeretnék mondani Vaskó-Leviczky Tündének, aki színvonalas munkájával és hozzájárulásával segített, hogy a dolgozat teljessé váljon.

Hálával gondolok a Növényi Morfogenezis Szabályozása csoport valamennyi tagjára, akik mindig vidám, gondtalan légkört teremtettek, és kérdéseimmel, kéréseimmel bármikor fordulhattam hozzájuk.

Hálás vagyok Dr. Rigó Gábornak, akihez bármikor bátran fordulhattam tanácsért, és aki nem egyszer segített ki a kísérletekhez szükséges anyagokkal is.

Szeretném megköszönni Prof. Dr. Koncz Csabának és Dr. Koncz Zsuzsának (Köln, Max Planck Intézet) a támogatását, és a lehetőséget, hogy pályám egy igen fontos időszakát náluk tölthettem. Meghatározó élmény volt számomra.

Szeretnék köszönetet mondani Dr. Markus Geislernek is (Fribourgi Egyetem, Svájc), hogy lehetőséget biztosított számomra a laboratóriumában, ahol új technikákat sajátíthattam el. Ennek köszönhetően fedezhettem fel, hogy az E2FB fontos szerepet játszhat az auxin transzportjában is. Ez a rövid, néhány hónapos időszak nagyon izgalmas szakasza volt az életemnek, amiért nagyon hálás vagyok neki és csoportjának egyaránt.

Itt szeretném megköszönni a segítséget a velünk együttmüködő csoportoknak, elsősorban az angliai Royal Holloway Egyetem School of Biological Sciences-ben dolgozó Dr. Horváth Beatrixnak, Prof. Dr. Bögre Lászlónak, és különös tekintettel Dr. Papdi Csabának, aki a kromatin immunoprecipitációt végezte.

Hálás vagyok szüleimnek és családomnak, akik mindvégig maximálisan támogattak, és biztosították a gondtalan egyetemi éveket.

Köszönöm barátaimnak, hogy annyi emlékezetes pillanatot szereztek az elmúlt évek folyamán, amikre mindig vidáman gondolhatok vissza, ezzel is élvezetessebbé téve az egyetemi éveket. 
Köszönöm a támogatást barátomnak, aki ösztönzésével és szövegszerkesztési bravúrjaival elősegítette a dolgozat megszületését.

Munkámat a következő pályázatok támogatták:

- Nemzeti Kutatási, Fejlesztési és Innovációs Hivatal OTKA K-105816-os pályázata

- Gazdaságfejlesztési és Innovációs Operatív Program GINOP-2.3.2-15-2016-00001 pályázata

- Campus Mundi SM-SMP-KA107/907/2019 számú pályázata

- Nemzeti Tehetség Program NTP-EFÖ-P-15-0392 pályázata

- Campus Hungary B2/1SZ/4176-es számú pályázata 


\section{IRODALOMJEGYZÉK}

1. Abraham Z, del Pozo JC (2012) Ectopic expression of E2FB, a cell cycle transcription factor, accelerates flowering and increases fruit yield in tomato. Journal of Plant Growth Regulation 31(1):11-24

2. Adachi S, Uchimiya H, Umeda M (2006) Expression of B2-type Cyclin-Dependent Kinase Is Controlled by Protein Degradation in Arabidopsis Thaliana. Plant and Cell Physiology 47(12):1683-6

3. Adams PD, Li X, Sellers WR, Baker KB, Leng X, Harper JW, Taya Y, Kaelin WG Jr (1999) Retinoblastoma protein contains a C-terminal motif that targets it for phosphorylation by cyclincdk complexes. Molecular and Cellular Biology 19(2):1068-80

4. Andersen SU, Buechel S, Zhao Z, Ljung K, Novak O, Busch W, Schuster C, Lohmann JU (2008) Requirement of B2-type cyclin-dependent kinases for meristem integrity in Arabidopsis thaliana. The Plant Cell 20:88-100

5. Andriankaja M, Dhondt S, De Bodt S, Vanhaeren H, Coppens F, De Milde L, Mühlenbock P, Skirycz A, Gonzalez N, Beemster GT, Inzé D (2012) Exit from proliferation during leaf development in Arabidopsis thaliana: A not-so-gradual process. Developmental Cell 17;22(1):6478

6. Asl LK, Dhondt S, Boudolf V, Beemster GT, Beeckman T, Inzé D, Govaerts W, De Veylder L (2011) Model-based analysis of Arabidopsis leaf epidermal cells reveals distinct division and expansion patterns for pavement and guard cells. Plant Physiology 156:2172-2183

7. Attwooll C, Lazzerini Denchi E, Helin K (2004) The E2F family: specific functions and overlapping interests. The EMBO Journal 8;23(24):4709-16

8. Baba AI, Rigó G, Ayaydin F, Rehman AU, Andrási N, Zsigmond L, Valkai I, Urbancsok J, Vass I, Pasternak T, Palme K, Szabados L, Cséplö Á (2018) Functional Analysis of the Arabidopsis thaliana CDPK-Related Kinase Family: AtCRK1 Regulates Responses to Continuous Light. International Journal of Molecular Sciences 25;19(5)

9. Bähler J (2005) Cell-cycle control of gene expression in budding and fission yeast. Annual Review of Genetics 39:69-94

10. Barberon M, Zelazny E, Robert S, Conéjéro G, Curie C, Friml J, Vert G (2011) Monoubiquitindependent endocytosis of the iron-regulated transporter 1 (IRT1) transporter controls iron uptake in plants. Proceedings of the National Academy of Sciences of the USA 108:E450-E458

11. Bassham DC, Brandizzi F, Otegui MS, Sanderfoot AA (2008) The secretory system of Arabidopsis. The Arabidopsis Book 6:e0116

12. Bechtold N, Ellis J, Pelletier G (1993) In planta Agrobacterium- mediated gene transfer by infiltration of adult Arabidopsis thaliana plants. Comptes Rendus de l'Académie des Sciences Paris, Life Sciences 316:1194-1199

13. Benková E, Michniewicz M, Sauer M, Teichmann T, Seifertová D, Jürgens G, Friml J (2003) Local, efflux-dependent auxin gradients as a common module for plant organ formation. The Cell 115:591-602

14. Berckmans B, Lammens T, Van Den Daele H, Magyar Z, Bögre L, De Veylder L (2011a) Lightdependent regulation of DEL1 is determined by the antagonistic action of E2Fb and E2Fc. Plant Physiology 157:1440-1451

15. Berckmans B, Vassileva V, Schmid SP, Maes S, Parizot B, Naramoto S, Magyar Z, Alvim Kamei CL, Koncz C, Bögre L (2011 b) Auxin-dependent cell cycle reactivation through transcriptional regulation of Arabidopsis E2Fa by lateral organ boundary proteins. The Plant Cell 23:3671-3683

16. Bisova K, Krylov DM, Umen JG (2005) Genome- wide annotation and expression profiling of cell cycle regulatory genes in Chlamydomonas reinhardtii. Plant Physiology 137:475-4491

17. Black EP, Hallstrom T, Dressman HK, West M, Nevins JR. (2005) Distinctions in the specificity of E2F function revealed by gene expression signatures. Proceedings of the National Academy of Sciences of the USA 1;102(44):15948-53

18. Blancaflor EB, Fasano JM, Gilroy S (1998) Mapping the functional roles of cap cells in the response of Arabidopsis primary roots to gravity. Plant Physiology 116(1):213-22

19. Bonechi C, Consumi M, Donati A, Leone G, MagnaniA, Tamasi G, Rossi C (2017) Bioenergy Systems for the Future. Elsevier 1:3-42

20. Borghi L, Gutzat R, Futterer J, Laizet Y, Hennig L, Gruissem W (2010) Arabidopsis retinoblastoma-related is required for stem cell maintenance, cell differentiation, and lateral organ production. The Plant Cell 22:1792-1811 
21. Boudolf V, Barrôco R, Engler Jde A, Verkest A, Beeckman T, Naudts M, Inzé D, De Veylder L (2004a) B1-type cyclin-dependent kinases are essential for the formation of stomatal complexes in Arabidopsis thaliana. The Plant Cell 16(4):945-55

22. Boudolf V, Inzé D, De Veylder L (2006) What if higher plants lack a CDC25 phosphatase? Trends in Plant Science 11(10):474-9

23. Boudolf V, Vlieghe K, Beemster GT, Magyar Z, Torres Acosta JA, Maes S, Van Der Schueren E, Inzé D, De Veylder L (2004b) The plant-specific cyclin-dependent kinase CDKB1;1 and transcription factor E2Fa-DPa control the balance of mitotically dividing and endoreduplicating cells in Arabidopsis. The Plant Cell 16(10):2683-92

24. Bouyer D, Heese M, Chen P, Harashima H, Roudier F, Grüttner C, Schnittger A (2018). Genomewide identification of RETINOBLASTOMA RELATED 1 binding sites in Arabidopsis reveals novel DNA damage regulators. PLoS Genetics, 14(11), e1007797

25. Bögre L, Magyar Z, López-Juez E (2008) New clues to organ size control in plants. Genome Biology 9(7):226

26. Breeden LL (2003) Periodic transcription: a cycle within a cycle. Current Biology 8;13(1):R31-8

27. Burgos PV, Mardones GA, Rojas AL, daSilva LLP, Prabhu Y, Hurley JH, Bonifacino JS (2010) Sorting of the Alzheimer's disease amyloid precursor protein mediated by the AP-4 complex. Developmental Cell 18:425-436

28. Chandler JW (2008) Cotyledon organogenesis. Journal of Experimental Botany, 59(11)2917-31

29. Chen HZ, Tsai SY, Leone G (2009) Emerging roles of E2Fs in cancer: An exit from cell cycle control. Nature Reviews Cancer 9:785-797

30. Cheng Y, Dai X, Zhao Y (2007 a) Auxin synthesized by the YUCCA flavin monooxygenasesis essential for embryogenesis and leaf formation in Arabidopsis. The Plant Cell 19(8):2430-9

31. Cheng Y, Qin G, Dai X, Zhao Y (2007 b) NPY1, a BTB-NPH3-like protein, plays a critical role in auxin-regulated organogenesis in Arabidopsis. Proceedings of the National Academy of Sciences of the USA 20;104(47):18825-9

32. Christensen S (2010) Agarose imprints of plant cell surfaces for imaging. Cold Spring Harbor Protocols 1;2010(9)

33. Churchman ML, Brown ML, Kato N, Kirik V, Hülskamp M, Inzé D, De Veylder L, Walker JD, Zheng Z, Oppenheimer DG, Gwin T, Churchman J, Larkin JC (2006) SIAMESE, a plant-specific cell cycle regulator, controls endoreplication onset in Arabidopsis thaliana. The Plant Cell 18(11):3145-57

34. Classon M, Dyson N (2001) p107 and p130: versatile proteins with interesting pockets. Experimental Cell Research 10;264(1):135-47

35. Clough SJ, Bent AF (1998) Floral dip: A simplified method for Agrobacterium-mediated transformation of Arabidopsis thaliana. The Plant Journal 16:735-743

36. Cobrinik D (2005) Pocket proteins and cell cycle control. Oncogene 18;24(17):2796-809

37. Costanzo M, Nishikawa JL, Tang X, Millman JS, Schub O, Breitkreuz K, Dewar D, Rupes I, Andrews B, Tyers M (2004) CDK activity antagonizes Whi5, an inhibitor of G1/S transcription in yeast. The Cell 25;117(7):899-913

38. Cress WD, Nevins JR (1996) A role for a bent DNA structure in E2F-mediated transcription activation. Molecular and Cellular Biology 16(5):2119-27

39. Cruz-Ramírez A, Díaz-Triviño S, Wachsman G, Du Y, Arteága-Vázquez M, Zhang H, Benjamins R, Blilou I, Neef AB, Chandler V, Scheres B (2013) A SCARECROW-RETINOBLASTOMA protein network controls protective quiescence in the Arabidopsis root stem cell organizer. PLoS Biology 11(11):e1001724

40. Dahiya A, Gavin MR, Luo RX, Dean DC (2000) Role of the LXCXE binding site in Rb function. Molecular and Cellular Biology 20(18):6799-805

41. de Bruin A, Maiti B, Jakoi L, Timmers C, Buerki R, Leone G (2003) Identification and characterization of E2F7, a novel mammalian E2F family member capable of blocking cellular proliferation. The Journal of Biological Chemistry 24;278(43):42041-9

42. de Bruin RA, McDonald WH, Kalashnikova TI, Yates J 3rd, Wittenberg C (2004) Cln3 activates G1-specific transcription via phosphorylation of the SBF bound repressor Whi5. The Cell 25;117(7):887-9

43. De Schutter K, Joubès J, Cools T, Verkest A, Corellou F, Babiychuk E, Van Der Schueren E, Beeckman T, Kushnir S, Inzé D, De Veylder L (2007) Arabidopsis WEE1 kinase controls cell cycle arrest in response to activation of the DNA integrity checkpoint. The Plant Cell 19(1):211-25

44. De Veylder L, Beeckman T, Beemster GT, de Almeida Engler J, Ormenese S, Maes S, Naudts M, Van Der Schueren E, Jacqmard A, Engler, Inzé D (2002) Control of proliferation, endoreduplication 
and differentiation by the Arabidopsis E2Fa-DPa transcription factor. The EMBO Journal 21:13601368

45. De Veylder L, Beeckman T, Inzé D (2007): The ins and outs of the plant cell cycle. Nature Reviews Molecular Cell Biology 8:655-665

46. De Veylder L, Larkin JC, Schnittger A (2011) Molecular control and function of endoreplication in development and physiology. Trends Plant Science16(11):624-34

47. Dell'Angelica EC (2009) AP-3-dependent trafficking and disease: The first decade. Current Opinion in Cell Biology 21:552-559

48. Dello Ioio R, Galinha C, Fletcher AG, Grigg SP, Molnar A, Willemsen V, Scheres B, Sabatini S, Baulcombe D, Maini PK, Tsiantis M (2012) A PHABULOSA/cytokinin feedback loop controls root growth in Arabidopsis. Current Biology 25;22(18):1699-704

49. Desvoyes B, de Mendoza A, Ruiz-Trillo I, Gutierrez C (2014) Novel roles of plant RETINOBLASTOMA-RELATED (RBR) protein in cell proliferation and asymmetric cell division. Journal of Experimental Botany 65(10):2657-66

50. Desvoyes B, Ramirez-Parra E, Xie Q, Chua NH, Gutierrez C (2006) Cell type-specific role of the retinoblastoma/E2F pathway during Arabidopsis leaf development. Plant Physiology140(1):67-80 Dewitte W, Murray JA (2003) The plant cell cycle. Annual Review of Plant Biology 54,235-264

51. Dhonukshe P, Tanaka H, Goh T, Ebine K, Mähönen AP, Prasad K, Blilou I, Geldner N, Xu J, Uemura T, Chory J, Ueda T, Nakano A, Scheres B, Friml J (2008) Generation of cell polarity in plants links endocytosis, auxin distribution and cell fate decisions. Nature 18;456(7224):962-6

52. Dhonukshe P, Aniento F, Hwang I, Robinson DG, Mravec J, Stierhof YD, Friml J (2007) Clathrinmediated constitutive endocytosis of PIN auxin efflux carriers in Arabidopsis. Current Biology 17:520-527

53. Dick FA, Rubin SM (2013) Molecular mechanisms underlying RB protein function. Nature Reviews. Molecular Cell Biology 14 (5): 297-306

54. Dimova DK, Dyson NJ (2005) The E2F transcriptional network: old acquaintances with new faces. Oncogene 18;24(17):2810-26

55. Dong J, MacAlister CA, Bergmann DC (2009) BASL controls asymmetric cell division in Arabidopsis. The Cell 26;137(7):1320-30.

56. Doonan J, Hunt T (1996) Cell cycle. Why don't plants get cancer? Nature 380:481-482

57. Dudits D (2007) Cell Cycle Control And Plant Develpment, Annual Plant Reviews. WileyBlackwell 32:1-30

58. Dyson N (1998) The regulation of E2F by pRB-family proteins. Genes \& Development 1;12(15):2245-62

59. Ebel C, Mariconti L, Gruissem W (2004) Plant retinoblastoma homologues control nuclear proliferation in the female gametophyte. Nature 429(6993):776-780

60. Ebine K, Fujimoto M, Okatani Y, Nishiyama T, Goh T, Ito E, Dainobu T, Nishitani A, Uemura T, Sato MH, Thordal-Christensen H, Tsutsumi N, Nakano A, Ueda T (2011) A membrane trafficking pathway regulated by the plant-specific RAB GTPase ARA6. Nature Cell Biology 13:853-859

61. Fehér A, Magyar Z (2015) Coordination of cell division and differentiation in plants in comparison to animals. Acta Biologica Szegediensis 59:275-289

62. Ferreira PC, Hemerly AS, Villarroel R, Van Montagu M, Inzé D (1991) The Arabidopsis functional homolog of the p34cdc2 protein kinase. The Plant Cell 3(5):531-40

63. Ferreira R, Magnaghi-Jaulin L, Robin P, Harel-Bellan A, Trouche D (1998): The three members of the pocket proteins family share the ability to repress E2F activity through recruitment of a histone deacetylase. Proceedings of the National Academy of Sciences of the USA 95(18):10493-10498

64. Fox S, Southam P, Pantin F, Kennaway R, Robinson S, Castorina G, Sánchez-Corrales YE, Sablowski R, Chan J, Grieneisen V, Marée AFM, Bangham JA, Coen E (2018) Spatiotemporal coordination of cell division and growth during organ morphogenesis. PLoS Biology $1 ; 16(11): \mathrm{e} 2005952$

65. Friml J, Vieten A, Sauer M, Weijers D, Schwarz H, Hamann T, Offringa R, Jürgens G (2003) Efflux-dependent auxin gradients establish the apical-basal axis of Arabidopsis. Nature 426:147153

66. Friml J, Wiśniewska J, Benková E, Mendgen K, Palme K (2002) Lateral relocation of auxin efflux regulator PIN3 mediates tropism in Arabidopsis. Nature 14;415(6873):806-9

67. Frolov MV, Huen DS, Stevaux O, Dimova D, Balczarek-Strang K, Elsdon M, Dyson NJ (2001) Functional antagonism between E2F family members. Genes \& Development 15;15(16):2146-60

68. Furutani M, Kajiwara T, Kato T, Treml BS, Stockum C, Torres-Ruiz RA, Tasaka M (2007) The gene MACCHI-BOU 4/ENHANCER OF PINOID encodes a NPH3-like protein and reveals 
similarities between organogenesis and phototropism at the molecular level. Development 134(21):3849-59

69. Gajiwala KS, Burley SK (2000) Winged helix proteins. Current Opinion in Structural Biology 10(1):110-6

70. Galinha C, Hofhuis H, Luijten M, Willemsen V, Blilou I, Heidstra R, Scheres B (2007) PLETHORA proteins as dose-dependent master regulators of Arabidopsis root development. Nature 449:1053-1057

71. Geisler M, Kolukisaoglu HU, Bouchard R, Billion K, Berger J, Saal B, Frangne N, Koncz-Kalman Z, Koncz C, Dudler R, Blakeslee JJ, Murphy AS, Martinoia E, Schulz B (2003) TWISTED DWARF1, a unique plasma membrane-anchored immunophilin-like protein, interacts with Arabidopsis multidrug resistance-like transporters AtPGP1 and AtPGP19. Molecular Biology of the Cell 14(10):4238-49

72. Geldner N, Richter S, Vieten A, Marquardt S, Torres-Ruiz RA, Mayer U, Ju rigens G (2004) Partial loss-of-function alleles reveal a role for GNOM in auxin transport-related, post-embryonic development of Arabidopsis. Development 131:389-400.

73. Giangrande PH, Zhu W, Schlisio S, Sun X, Mori S, Gaubatz S, Nevins JR (2004) A role for E2F6 in distinguishing G1/S- and G2/M-specific transcription. Genes \& Development 1;18(23):2941-51

74. Guo J, Song J, Wang F, Zhang XS (2007) Genome-wide identification and expression analysis of rice cell cycle genes. Plant Molecular Biology, 64(4),349-360

75. Gutierrez C (2009). The Arabidopsis cell division cycle. The Arabidopsis Book 7:e0120

76. Gutiérrez-Escribano P, Nurse P (2015) A single cyclin-CDK complex is sufficient for both mitotic and meiotic progression in fission yeast. Nature Communications 20;6:6871

77. Gutzat R, Borghi L, Fütterer J, Bischof S, Laizet Y, Hennig L, Feil R, Lunn J, Gruissem W (2011) RETINOBLASTOMA-RELATED PROTEIN controls the transition to autotrophic plant development. Development 138(14):2977-86

78. Happel N, Höning S, Neuhaus JM, Paris N, Robinson DG, Holstein SE (2004) Arabidopsis $\mu$ Aadaptin interacts with the tyrosine motif of the vacuolar sorting receptor VSR-PS1. Plant Journal 37: $678-693$

79. Harashima H, Dissmeyer N, Schnittger A (2013) Cell cycle control across the eukaryotic kingdom. Trends in Cell Biology 23(7):345-356

80. Henriques R, Magyar Z, Bogre L (2013) S6K1 and E2FB are in mutually antagonistic regulatory links controlling cell growth and proliferation. Plant Signaling \& Behavior 8:6,e24367

81. Henriques R, Magyar Z, Monardes A, Khan S, Zalejski C, Orellana J, Szabados L, de la Torre C, Koncz C, Bögre L (2010) Arabidopsis S6 kinase mutants display chromosome instability and altered RBR1-E2F pathway activity. The EMBO Journal 1;29(17):2979-93

82. Heyman J, Van den Daele H, De Wit K, Boudolf V, Berckmans B, Verkest A, Alvim Kamei CL, De Jaeger G, Koncz C, De Veylder L (2011) Arabidopsis ULTRAVIOLET-B-INSENSITIVE4 maintains cell division activity by temporal inhibition of the anaphase-promoting complex/cyclosome. The Plant Cell 23(12):4394-410

83. Hibara K, Karim MR, Takada S, Taoka K, Furutani M, Aida M, Tasaka M (2006) Arabidopsis CUP-SHAPED COTYLEDON3 regulates postembryonic shoot meristem and organ boundary formation. The Plant Cell 18(11):2946-57

84. Hirayama T, Imajuku Y, Anai T, Matsui M, Oka A (1991) Identification of two cell-cyclecontrolling cdc2 gene homologs in Arabidopsis thaliana. Gene 15;105(2):159-65

85. Hirschi A, Cecchini M, Steinhardt RC, Schamber MR, Dick FA, Rubin SM (2010) An overlapping kinase and phosphatase docking site regulates activity of the retinoblastoma protein. Nature Structural \& Molecular Biology 17(9):1051-7

86. Hirst J, Barlow LD, Francisco GC, Sahlender D, Seaman MNJ, Dacks JB, Robinson MS (2011) The fifth adaptor protein complex. PLoS Biology 9:e1001170

87. Hirst J, Borner GHH, Antrobus R, Peden AA, Hodson NA, Sahlender DA, Robinson MS (2012) Distinct and overlapping roles for AP-1 and GGAs revealed by the "knocksideways" system. Current Biology 22:1711-1716

88. Hirt H, Páy A, Györgyey J, Bakó L, Németh K, Bögre L, Schweyen RJ, Heberle-Bors E, Dudits D (1991) Complementation of a yeast cell cycle mutant by an alfalfa cDNA encoding a protein kinase homologous to p34cdc2. Proceedings of the National Academy of Sciences of the USA $1 ; 88(5): 1636-40$

89. Hong JH, Chu H, Zhang C, Ghosh D, Gong X, Xu J (2015) A quantitative analysis of stem cell homeostasis in the Arabidopsis columella root cap. Frontiers in Plant Science 27;6:206 
90. Horiguchi G, Fujikura U, Ferjani A, Ishikawa N, Tsukaya H (2006) Large-scale histological analysis of leaf mutants using two simple leaf observation methods: Identification of novel genetic pathways governing the size and shape of leaves. The Plant Journal 48:638-644

91. Horiguchi G, Tsukaya H (2011) Organ size regulation in plants: insights from compensation. Frontiers in Plant Science 2:24

92. Horvath B, Kourova H, Nagy S, Nemeth E, Magyar Z, Papdi C, Ahmad Z, Sanchez-Perez GF, Perilli S, Blilou I, Pettkó-Szandtner A, Darula Z, Meszaros T, Binarova P, Bogre L, Scheres B (2017) Arabidopsis RETINOBLASTOMA RELATED directly regulates DNA damage responses through functions beyond cell cycle control. The EMBO Journal 36:1261-1278

93. Huang T, Harrar Y, Lin C, Reinhart B, Newell NR, Talavera-Rauh F, Hokin SA, Barton MK, Kerstetter RA (2014) Arabidopsis KANADI1 acts as a transcriptional repressor by interacting with a specific cis-element and regulates auxin biosynthesis, transport, and signaling in opposition to HD-ZIPIII factors. The Plant Cell 26(1):246-62

94. Ingouff M, Jullien PE, Berger F (2006) The female gametophyte and the endosperm control cell proliferation and differentiation of the seed coat in Arabidopsis. The Plant Cell 18(12):3491-501

95. Irani NG, Di Rubbo S, Mylle E, Van den Begin J, Schneider-Pizoń J, Hniliková J, Śíša M, Buyst D, Vilarrasa-Blasi J, Szatmári AM, Van Damme D, Mishev K, Codreanu MC, Kohout L, Strnad M, Caño-Delgado AI, Friml J, Madder A, Russinova E (2012) Fluorescent castasterone reveals BRI1 signaling from the plasma membrane. Nature Chemical Biology 6;8(6):583-9

96. Iyer VR, Horak CE, Scafe CS, Botstein D, Snyder M, Brown PO (2001) Genomic binding sites of the yeast cell-cycle transcription factors SBF and MBF. Natur 25;409(6819):533-8

97. Johnson DG, Schneider-Broussard R (1998) Role of E2F in cell cycle control and cancer. Frontiers Bioscience 27;3:d447-8

98. Johnston AJ, Matveeva E, Kirioukhova O, Grossniklaus U, Gruissem W (2008) A dynamic reciprocal RBR-PRC2 regulatory circuit controls Arabidopsis gametophyte development. Current Biology 18(21):1680-1686

99. Karimi M, Inzé D, Depicker A (2002) GATEWAY vectors for Agrobacterium-mediated plant transformation. Trends in Plant Science 7:193-195

100. Kim YS, Kim SG, Park JE, Park HY, Lim MH, Chua NH, Park CM (2006) A Membrane-Bound NAC Transcription Factor Regulates Cell Division in Arabidopsis. The Plant Cell 18(11):3132-44

101. Kitakura S, Vanneste S, Robert S, Löfke C, Teichmann T, Tanaka H, Friml J (2011) Clathrin mediates endocytosis and polar distribution of PIN auxin transporters in Arabidopsis. The Plant Cell 23(5):1920-31

102. Kobayashi K, Suzuki T, Iwata E, Magyar Z, Bögre L, Ito M (2015a) MYB3Rs, plant homologs of Myb oncoproteins, control cell cycle-regulated transcription and form DREAM-like complexes. Transcription 6:106-111

103. Kobayashi K, Suzuki T, Iwata E, Nakamichi N, Suzuki T, Chen P, Ohtani M, Ishida T, Hosoya H, Müller S, Leviczky T, Pettkó-Szandtner A, Darula Z, Iwamoto A, Nomoto M, Tada Y, Higashiyama T, Demura T, Doonan JH, Hauser MT, Sugimoto K, Umeda M, Magyar Z, Bögre L, Ito M (2015b) Transcriptional repression by MYB3R proteins regulates plant organ growth. The EMBO Journal 34:1992-2007

104. Kosugi S, Ohashi Y (2002a) E2Ls, E2F-like repressors of Arabidopsis that bind to E2F sites in a monomeric form. The Journal of Biological Chemistry 10;277(19):16553-8

105. Kosugi S, Ohashi Y (2002b) Interaction of the Arabidopsis E2F and DP proteins confers their concomitant nuclear translocation and transactivation. Plant Physiology 128:833-843

106. Kotogány E, Dudits D, Horváth G, Ayaydin F (2010) A rapid and robust assay for detection of Sphase cell cycle progression in plant cells and tissues by using ethynyl deoxyuridine. Plant Methods 6:5

107. Kumar N, Larkin JC (2017) Why do plants need so many cyclin-dependent kinase inhibitors? Plant Signal and Behavior 12(2):e1282021

108. La H, Li J, Ji Z, Cheng Y, Li X, Jiang S, Venkatesh PN, Ramachandran S (2006) Genome-wide analysis of cyclin family in rice (Oryza Sativa L.). Molecular Genetics and Genomics 275(4),374386

109. Lau OS, Bergmann DC (2012) Stomatal development: a plant's perspective on cell polarity, cell fate transitions and intercellular communication. Development 139(20):3683-92

110. Laxmi A, Gupta A, Mishra BS, Singh M, Jamsheer KM, Kushwah S (2013) Signal Integration, Auxin Homeostasis, and Plant Development. Signaling and Communication in Plants 17:45-79

111. Le J, Liu XG, Yang KZ, Chen XL, Zou JJ, Wang HZ, Wang M, Vanneste S, Morita M, Tasaka M, Ding ZJ, Friml J, Beeckman T, Sack F (2014) Auxin transport and activity regulate stomatal patterning and development. Nature Communications 5:3090 
112. Lee H, Ohno K, Voskoboynik Y, Ragusano L, Martinez A, Dimova DK (2010) Drosophila RB proteins repress differentiation-specific genes via two different mechanisms. Molecular and Cellular Biology 30(10):2563-2577

113. Lee JO, Russo AA, Pavletich NP (1998) Structure of the retinoblastoma tumour-suppressor pocket domain bound to a peptide from HPV E7. Nature 26;391(6670):859-65

114. Lee TC, Gombos DS, Harbour W, Mansfield NC, Murphree AL (2013) Retinoblastoma. Retina 5: 2104-2149

115. Lendvai A, Pettkó-Szandtner A, Csordás-Tóth E, Miskolczi P, Horváth GV, Györgyey J, Dudits D (2007) Dicot and monocot plants differ in retinoblastoma-related protein subfamilies. Journal of Experimental Botany, 58(7), 1663-1675.

116. Lenhard M, Bohnert A, Jürgens G, Laux T (2001) Termination of stem cell maintenance in Arabidopsis floral meristems by interactions between WUSCHEL and AGAMOUS. The Cell 15;105(6):805-14

117. Lenhard M, Jürgens G, Laux T (2002) The WUSCHEL and SHOOTMERISTEMLESS genes fulfil complementary roles in Arabidopsis shoot meristem regulation. Development 129(13):3195-206

118. Leviczky T, Molnár E, Papdi C, Öszi E, Horváth GV, Vizler C, Nagy V, Pauk J, Bögre L, Magyar $\mathrm{Z}$ (2019) E2FA and E2FB transcription factors coordinate cell proliferation with seed maturation. Development 26;146(22)

119. Li J, Ran C, Li E, Gordon F, Comstock G, Siddiqui H, Cleghorn W, Chen HZ, Kornacker K, Liu CG, Pandit SK, Khanizadeh M, Weinstein M, Leone G, de Bruin A (2008) Synergistic function of E2F7 and E2F8 is essential for cell survival and embryonic development. Developmental Cell 14(1):62-75

120. Li X, Cai W, Liu Y, Li H, Fu L, Liu Z, Xu L, Liu H, Xu T, Xiong Y (2017) Differential TOR activation and cell proliferation in Arabido root and shoot apexes. Proceedings of the National Academy of Sciences of the USA 114: 2765-2770

121. Logan N, Graham A, Zhao X, Fisher R, Maiti B, Leone G, La Thangue NB (2005) E2F-8: an E2F family member with a similar organization of DNA-binding domains to E2F-7. Oncogene $21 ; 24(31): 5000-4$

122. Magae J, Wu CL, Illenye S, Harlow E, Heintz NH (1996) Nuclear localization of DP and E2F transcription factors by heterodimeric partners and retinoblastoma protein family members. Journal of Cell Science 109(7):1717-26

123. Magyar Z (2008) Keeping the Balance Between Proliferation and Differentiation by the E2F Transcriptional Regulatory Network is Central to Plant Growth and Development. Plant Cell Monographs 10:89-105

124. Magyar Z, Atanassova A, De Veylder L, Rombauts S, Inzé D (2000) Characterization of two distinct DP-related genes from Arabidopsis thaliana. FEBS Letters 486:79-87

125. Magyar Z, Bakó L, Bogre L, Dedeoglu D, Kapros T, Dudits D (1993) Active cde2 genes and cell cycle phase-spe- cific cdc2-related kinase complexes in hormone-stimulated alfalfa cells. The Plant Journal 4,151-161

126. Magyar Z, De Veylder L, Atanassova A, Bakó L, Inzé D, Bögre L (2005) The role of the Arabidopsis E2FB transcription factor in regulating auxin-dependent cell division. The Plant Cell 17(9):2527-41

127. Magyar Z, Horváth B, Khan S, Mohammed B, Henriques R, De Veylder L, Bakó L, Scheres B, Bögre L (2012) Arabidopsis E2FA stimulates proliferation and endocycle separately through RBRbound and RBR-free complexes. The EMBO Journal 31:1480-1493

128. Magyar Z, Mészáros T, Miskolczi P, Deák M, Fehér A, Brown S, Kondorosi E, Athanasiadis A, Pongor S, Bilgin M, Bakó L, Koncz C, Dudits D (1997) Cell cycle phase specificity of putative cyclin-dependent kinase variants in synchronized alfalfa cells. The Plant Cell 9(2):223-35

129. Mariconti L, Pellegrini B, Cantoni R, Stevens R, Bergounioux C, Cella R, Albani D (2002) The E2F family of transcription factors from Arabidopsis thaliana. Novel and conserved components of the retinoblastoma/E2F pathway in plants. The Journal of Biological Chemistry 22;277(12):9911-9

130. Matos JL, Lau OS, Hachez C, Cruz-Ramírez A, Scheres B, Bergmann DC (2014) Irreversible fate commitment in the Arabidopsis stomatal lineage requires a FAMA and RETINOBLASTOMARELATED module. eLife 10;3

131. McMahon HT, Boucrot E (2011) Molecular mechanism and physiological functions of clathrinmediated endocytosis. Nature Reviews Molecular Cell Biology 12:517-533

132. Mitra SK, Walters BT, Clouse SD, Goshe MB (2009) An efficient organic solvent based extraction method for the proteomic analysis of Arabidopsis plasma membranes. Journal of proteome research $8(6): 2752-67$ 
133. Morgan DO (1995) Principles of CDK regulation. Nature 374:131-134

134. Morgan DO (2007) The Cell Cycle: Principles of Control. Chapter 3 The Cell-Cycle Control System. New Science Press Ltd 1:28-58

135. Nadeau JA, Sack FD (2002) Control of stomatal distribution on the Arabidopsis leaf surface. Science 31;296(5573):1697-700

136. Noh B, Murphy AS, Spalding EP (2001) Multidrug resistance-like genes of Arabidopsis required for auxin transport and auxin-mediated development. The Plant Cell13(11):2441-54

137. Nowack MK, Harashima H, Dissmeyer N, Zhao X, Bouyer D, Weimer AK, De Winter F, Yang F, Schnittger A (2012) Genetic framework of cyclin-dependent kinase function in Arabidopsis. Developmental Cell 15;22(5):1030-40

138. Ogawa H, Ishiguro K, Gaubatz S, Livingston DM, Nakatani Y (2002) A complex with chromatin modifiers that occupies E2F- and Myc-responsive genes in G0 cells. Science. 10;296(5570):11326

139. Ohashi-Ito K, Bergmann DC (2006) Arabidopsis FAMA controls the final proliferation/differentiation switch during stomatal development. The Plant Cell 18(10):2493-505

140. Page BD, Guedes S, Waring D, Priess JR (2001) The C. elegans E2F- and DP-related proteins are required for embryonic asymmetry and negatively regulate Ras/MAPK signaling. Molecular Cell 7(3):451-60

141. Park J, Kim YS, Kim SG, Jung JH, Woo JC, Park CM (2011) Integration of auxin and salt signals by the NAC transcription factor NTM2 during seed germination in Arabidopsis. Plant Physiology 156(2):537-49

142. Perrot-Rechenmann C (2010) Cellular responses to auxin: division versus expansion. Cold Spring Harbor Perspectives in Biology 2(5):a001446

143. Perry J, Kornbluth S (2007) Cdc25 and Wee1: analogous opposites? Cell Division 2:12

144. Petrásek J, Mravec J, Bouchard R, Blakeslee JJ, Abas M, Seifertová D, Wisniewska J, Tadele Z, Kubes M, Covanová M, Dhonukshe P, Skupa P, Benková E, Perry L, Krecek P, Lee OR, Fink GR, Geisler M, Murphy AS, Luschnig C, Zazímalová E, Friml J (2006) PIN Proteins Perform a RateLimiting Function in Cellular Auxin Efflux. Science 12;312(5775):914-8

145. Pramila T, Wu W, Miles S, Noble WS, Breeden LL (2006) The Forkhead transcription factor Hcml regulates chromosome segregation genes and fills the S-phase gap in the transcriptional circuitry of the cell cycle. Genes \& Development 15;20(16):2266-78

146. Reinhardt D, Pesce ER, Stieger P, Mandel T, Baltensperger K, Bennett M, Traas J, Friml J, Kuhlemeier C (2003) Regulation of phyllotaxis by polar auxin transport. Nature 20;426(6964):25560

147. Reinhardt D, Mandel T, Kuhlemeier C (2000) Auxin regulates the initiation and radial position of plant lateral organs. The Plant Cell 12, 507-518

148. Risal S, Adhikari D, Liu K (2016) Animal Models for Studying the In Vivo Functions of Cell Cycle CDKs. Cyclin-Dependent Kinase (CDK) Inhibitors. Springer Science+Business Media 1336:155166

149. Robert HS, Grunewald W, Sauer M, Cannoot B, Soriano M, Swarup R, Weijers D, Bennett M, Boutilier K, Friml J (2015) Plant embryogenesis requires AUX/LAX-mediated auxin influx. Development 15;142(4):702-11

150. Robinson DO, Coate JE, Singh A, Hong L, Bush M, Doyle JJ, Roeder AHK (2018) Ploidy and Size at Multiple Scales in the Arabidopsis Sepal. The Plant Cell 30(10):2308-2329

151. Rounds CM, Lubeck E, Hepler PK, Winship LJ (2011) Propidium iodide competes with $\mathrm{Ca}^{2+}$ to label pectin in pollen tubes and Arabidopsis root hairs. Plant Physiology 157(1):175-87

152. Rubin SM, Gall AL, Zheng N, Pavletich NP (2005) Structure of the Rb C-terminal domain bound to E2F1-DP1: a mechanism for phosphorylation-induced E2F release. The Cell 16;123(6):1093106

153. Sadasivam S, DeCaprio JA (2013) The DREAM complex: master coordinator of cell cycledependent gene expression. Nature Reviews Cancer 13(8):585-595

154. Saleh A, Alvarez-Venegas R, Avramova Z (2008) An efficient chromatin immunoprecipitation (ChIP) protocol for studying histone modifications in Arabidopsis plants. Nature Protocols 3(6): 1018-25

155. Santamaría D, Barrière C, Cerqueira A, Hunt S, Tardy C, Newton K, Cáceres JF, Dubus P, Malumbres M, Barbacid M (2007) Cdk1 is sufficient to drive the mammalian cell cycle. Nature, 448(7155),811-815

156. Schaller GE, Street IH, Kieber JJ (2014) Cytokinin and the cell cycle. Current Opinion in Plant Biology 21:7-15. 
157. Schwab R, Ossowski S, Riester M, Warthmann N, Weigel D (2006) Highly Specific Gene Silencing by Artificial MicroRNAs in Arabidopsis. The Plant Cell 18(5):121-1133

158. Shen WH (2002) The plant E2F-Rb pathway and epigenetic control. Trends in Plant Science 7(11):505-11

159. Simmons AR, Davies KA, Wang W, Liu Z, Bergmann DC (2019) SOL1 and SOL2 regulate fate transition and cell divisions in the Arabidopsis stomatal lineage. Development 4;146(3)

160. Simon I, Barnett J, Hannett N, Harbison CT, Rinaldi NJ, Volkert TL, Wyrick JJ, Zeitlinger J, Gifford DK, Jaakkola TS, Young RA (2001) Serial regulation of transcriptional regulators in the yeast cell cycle. The Cell. 21;106(6):697-708

161. Souter M, Topping J, Pullen M, Friml J, Palme K, Hackett R, Grierson D, Lindsey K (2002) hydra Mutants of Arabidopsis are defective in sterol profiles and auxin and ethylene signaling. The Plant Cell 14(5):1017-31

162. Sozzani R, Maggio C, Varotto S, Canova S, Bergounioux C, Albani D, Cella R (2006) Interplay between Arabidopsis activating factors $\mathrm{E} 2 \mathrm{Fb}$ and $\mathrm{E} 2 \mathrm{Fa}$ in cell cycle progression and development. Plant Physiology 140: 1355-1366

163. Stevaux O, Dyson NJ (2002) A revised picture of the E2F transcriptional network and RB function. Current Opinion in Cell Biology 14:684-691

164. Street IH, Mathews DE, Yamburkenko MV, Sorooshzadeh A, John RT, Swarup R, Bennett MJ, Kieber JJ, Schaller GE (2016) Cytokinin acts through the auxin influx carrier AUX1 to regulate cell elongation in the root. Development 1;143(21):3982-3993

165. Takatsuka H, Ohno R, Umeda M (2009) The Arabidopsis cyclin-dependent kinase-activating kinase CDKF; 1 is a major regulator of cell proliferation and cell expansion but is dispensable for CDKA activation. The Plant Journal 59(3):475-87

166. Tanase CP, Ogrezeanu I, Badiu C (2012) MicroRNAs. Molecular Pathology of Pituitary Adenomas 1:91-96

167. Torres Acosta JA, Fowke LC, Wang H (2011) Analyses of phylogeny, evolution, conserved sequences and genome-wide expression of the ICK/KRP family of plant CDK inhibitors. Annals of Botany 107(7):1141-57

168. Torres Ruiz RA (2004) Polarity in Plants: Polarity in Arabidopsis embryogenesis. Blackwell Publishin Ltd. 1:157-191.

169. Treml BS, Winderl S, Radykewicz R, Herz M, Schweizer G, Hutzler P, Glawischnig E, Torres Ruiz RA (2005) The gene ENHANCER OF PINOID controls cotyledon development in the Arabidopsis embryo. Development 132:4063-4074

170. Trewavas AJ (1992) What remains of the Cholodny-Went theory? Plan Cell Environ 15:759-794

171. Umbrasaite J, Schweighofer A, Kazanaviciute V, Magyar Z, Ayatollahi Z, Unterwurzacher V, Choopayak C, Boniecka J, Murray JA, Bogre L, Meskiene I (2010) MAPK phosphatase AP2C3 induces ectopic proliferation of epidermal cells leading to stomata development in Arabidopsis. PLoS One 23;5(12):e15357

172. Umeda M, Bhalerao RP, Schell J, Uchimiya H, Koncz C (1998) A distinct cyclin-dependent kinaseactivating kinase of Arabidopsis thaliana. Proceedings of the National Academy of Sciences of the USA 28;95(9):5021-6

173. van den Heuvel S, Dyson NJ (2008) Conserved functions of the pRB and E2F families. Nature Reviews Molecular Cell Biology 9:713-724

174. van der Vliet PC, Verrijzer CP (1993) Bending of DNA by transcription factors. BioEssays 15(1):25-32

175. Vandepoele K, Vlieghe K, Florquin K, Hennig L, Beemster GTS, Gruissem W, Van de Peer Y, Inzé D, De Veylder L (2005) Genome-wide identification of potential plant E2F target genes. Plant Physiology 139(1):316-328

176. Vélez-Cruz R, G. Johnson D (2017) The Retinoblastoma (RB) Tumor Suppressor: Pushing Back against Genome Instability on Multiple Fronts. International Journal of Molecular Sciencis 18(8): 1776

177. Vidal M, Braun P, Chen E, Boeke JD, Harlow E (1996) Genetic characterization of a mammalian protein-protein interaction domain by using a yeast reverse two-hybrid system. Proceedings of the National Academy of Sciences of the USA 17;93(19):10321-6

178. Vigo E, Müller H, Prosperini E, Hateboer G, Cartwright P, Moroni MC, Helin K (1999) CDC25A phosphatase is a target of E2F and is required for efficient E2F-induced S phase. Molecular and Cellular Biology 19(9):6379-95

179. Vik A, Rine J (2000) Membrane biology: Membrane-regulated transcription. Current biology 30;10(23):R869-71 
180. Vlot AC, Neeleman L, Linthorst HJ, Bol JF (2001) Role of the 3'-untranslated regions of alfalfa mosaic virus RNAs in the formation of a transiently expressed replicase in plants and in the assembly of virions. Journal of Virology 75(14):6440-9

181. Voinnet O, Pinto YM, Baulcombe DC (1999) Suppression of gene silencing: a general strategy used by diverse DNA and RNA viruses of plants. Proceedings of the National Academy of Sciences of the USA 23;96(24):14147-52

182. Wang G, Kong H, Sun Y, Zhang X, Zhang W, Altman N, DePamphilis CW, Ma H (2004) Genomewide analysis of the cyclin family in Arabidopsis and comparative phylogenetic analysis of plant cyclin-like proteins. Plant physiology, 135(2),1084-1099

183. Wang L, Ruan YL (2013) Regulation of cell division and expansion by sugar and auxin signaling. Frontiers in Plant Science 30;4:163

184. Wang S, Gu Y, Zebell SG, Anderson LK, Wang W, Mohan R, Dong X (2014) A noncanonical role for the CKI-RB-E2F cell-cycle signaling pathway in plant effector-triggered immunity. Cell Host \& Microbe 16:787-794

185. Wildwater M, Campilho A, Perez-Perez JM, Heidstra R, Blilou I, Korthout H, Chatterjee J, Mariconti L, Gruissem W, Scheres B (2005) The RETINOBLASTOMA-RELATED gene regulates stem cell maintenance in Arabidopsis roots. The Cell 29;123(7):1337-49

186. Winter D, Vinegar B, Nahal H, Ammar R, Wilson GV, Provart NJ (2007) An "Electronic Fluorescent Pictograph" browser for exploring and analyzing large-scale biological data sets. Public Library of Science 8;2(8):e718

187. Wu CL, Zukerberg LR, Ngwu C, Harlow E, Lees JA (1995) In vivo association of E2F and DP family proteins. Molecular and Cellular Biology 15(5):2536-46

188. Wu H, Zheng R, Hao Z, Meng Y, Weng Y, Zhou X, Zhu L, Hu X, Wang G, Shi J, Chen J (2019) Cunninghamia lanceolata PSK Peptide Hormone Genes Promote Primary Root Growth and Adventitious Root Formation. Plants 8(11),520

189. Wu L, Luo P, Di DW, Wang L, Wang M, Lu CK, Wei SD, Zhang L, Zhang TZ, Amakorová P, Strnad M, Novák O, Guo GQ (2015) Forward genetic screen for auxin-deficient mutants by cytokinin. Scientific Reports 6;5:11923

190. Wu Z G, Jiang W, Tao Z M, Pan X J, Yu W H, Huang H L (2020) Morphological and stage-specific transcriptome analyses reveal distinct regulatory programs underlying yam (Dioscorea alata L.) bulbil growth. Journal of Experimental Botany 71(6),1899-1914.

191. Xie J, Han F, Shi Y (2015) Single-prolonged stress activates the transcription factor ATF6 $\alpha$ branch of the unfolded protein response in rat neurons of dorsal raphe nucleus. Molecular and Cellular Biochemistry 399(1-2):209-16

192. Xie Z, Lee E, Lucas JR, Morohashi K, Li D, Murray JA, Sack FD, Grotewold E (2010) Regulation of cell proliferation in the stomatal lineage by the Arabidopsis MYB FOUR LIPS via direct targeting of core cell cycle genes. The Plant Cell 22(7):2306-21

193. Xiong Y, Jiao Y (2019) The Diverse Roles of Auxin in Regulating Leaf Development. Plants $23 ; 8(7)$

194. Xiong Y, McCormack M, Li L, Hall Q, Xiang C, Sheen J (2013) Glucose-TOR signalling reprograms the transcriptome and activates meristems. Nature 496(7444),181-186

195. Yamaoka S, Shimono Y, Shirakawa M, Fukao Y, Kawase T, Hatsugai N, Tamura K, Shimada T, Hara-Nishimura I (2013) Identification and dynamics of Arabidopsis adaptor protein-2 complex and its involvement in floral organ development. The Plant Cell 25(8):2958-69

196. Yang K, Wang H, Xue S, Qu X, Zou J, Le J (2014) Requirement for A-type cyclin-dependent kinase and cyclins for the terminal division in the stomatal lineage of Arabidopsis. The Journal of Experimental Botany 65(9):2449-61

197. Zacksenhaus E, Jiang Z, Chung D, Marth JD, Phillips RA, Gallie BL (1996) pRb controls proliferation, differentiation, and death of skeletal muscle cells and other lineages during embryogenesis. Genes \& Development 1;10(23):3051-64

198. Zádníková P, Petrásek J, Marhavy P, Raz V, Vandenbussche F, Ding Z, Schwarzerová K, Morita MT, Tasaka M, Hejátko J, Van Der Straeten D, Friml J, Benková E (2010) Role of PIN-mediated auxin efflux in apical hook development of Arabidopsis thaliana. Development 137(4):607-17

199. Žádníková P, Wabnik K, Abuzeineh A, Gallemi M, Van Der Straeten D, Smith RS, Inzé D, Friml J, Prusinkiewicz P, Benková E (2016) A Model of Differential Growth-Guided Apical Hook Formation in Plants. The Plant Cell 28(10):2464-2477

200. Zhang HS, Gavin M, Dahiya A, Postigo AA, Ma D, Luo RX, Harbour JW, Dean DC (2000) Exit from $\mathrm{G} 1$ and $\mathrm{S}$ phase of the cell cycle is regulated by repressor complexes containing HDAC-RbhSWI/SNF and Rb-hSWI/SNF. The Cell 101(1):79-89 
201. Zhang X, Henriques R, Lin SS, Niu QW, Chua NH (2006) Agrobacterium-mediated transformation of Arabidopsis thaliana using the floral dip method. Nature Protocols 1:641-646

202. Zheng HQ, Staehelin LA (2001) Nodal endoplasmic reticulum, a specialized form of endoplasmic reticulum found in gravity-sensing root tip columella cells. Plant Physiology 125:252-265

203. Zhou F, Roy B, von Arnim AG (2010) Translation reinitiation and development are compromised in similar ways by mutations in translation initiation factor eIF3h and the ribosomal protein RPL24. BMC Plant Biology 27;10:1

\section{Felhasznált honlapok:}

1. https://www.uniprot.org

2. http://www.bar.utoronto.ca/efp/cgi-bin/efpWeb.cgi

3. https://www.arabidopsis.org

4. https://www.microscopyu.com 


\section{ÖSSZEFOGLALÁS}

A jelenlegi növényi sejtciklus modell alapján az E2F transzkripciós faktorok a sejtosztódásba lépéshez fontos szabályozási gének kizárólagos aktivátorai. A molekuláris modellnövényben, az Arabidopsisban két aktivátor E2F található, melyekröl feltételezik, hogy redundáns módon szabályozzák a sejtciklus gének működését. Az eddigi, E2FB-ről szóló eredmények az E2FB növényi sejtekben illetve transzgenikus növényekben történő túltermeltetéséből származtak, ami alapján kevésbé lehet az E2FB natív szerepéről pontos képet formálni. Doktori munkám során az E2FB szerepét különböző T-DNS inszerciós mutáns növényekben, domináns negatív túltermelő vonalakban, és olyan transzgenikus növényekben vizsgáltam, ahol az E2FB fehérjét a saját doménjében tudtuk nyomon követni. Tanulmányoztam az E2FB fehérje levélsejtekben történő előfordulását és kölcsönható partnereit is. Döntően az E2FB fejlődésben betöltött szerepét vizsgáltam elsősorban a levél fejlődése során. Az eredményeim alapján a következő megállapításokat és megfigyeléseket tehettem:

1. Kimutattuk, hogy a levélfejlődés során az E2FB az RBR szigorú ellenőrzése alatt áll. Az E2FB saját expressziós doménjében történő jelentős túltermeltetése az RBR szintben is hasonló mértékü emelkedést eredményezett, és az E2FB-RBR komplex mennyisége ezzel arányosan nött meg. Ennek köszönhetően kevesebb levélsejt született, mint a hasonló korú kontroll levélben.

2. Az E2FB közvetlenül szabályozza a saját szabályozó molekuláinak a kifejeződését (RBR és CIKLIND3;1). Ezek a negatív (RBR) és pozitív (CIKLIND3;1) visszacsatolási (feed-back) mechanizmusok biztosíthatják a levél fejlődése során a sejtosztódás és a differenciálódás közti egyensúly stabilitását.

3. Domináns negatív E2FB mutánsok jellemzésén keresztül (E2FB $\left.{ }^{\triangle \mathrm{RBR}}\right)$ kimutattuk, hogy az E2FB a zárósejtek kialakulásáért felelős levél merisztemoidokban represszor komplexet formál az RBR fehérjével, és döntő szerepet játszik a levélsejtek kialakulásában. Mindez arra enged következtetni, hogy az E2FB szerepe sejttípustól függően lehet aktivátor vagy represszor.

4. Az RBR az E2FB gátlásán keresztül tartja fent a nyugalmi állapotot azokban a levél sejtekben, amelyek már elkötelezték magukat a differenciálódás irányába. Az E2FB aktiválódása ezekben a már megnyúlt sejtekben indukálta az osztódásba történő visszalépést. Mindezek alapján az E2FB fejlődési állapottól függően lehet aktivátor és represszor is a levélsejtekben. 
5. Az E2FB hiányában a sejtciklus gének aktivitása csökkent, de fehérje szinten nem detektáltunk változást. Mindez kompenzációs folyamatra vagy folyamatokra enged következtetni. Kimutattuk, hogy az E2FB és az E2FA fehérjék egymásra negatívan hatnak: növekednek a másik hiányában, illetve csökkenek, ha a másik mennyisége megnő. Mindezek alapján feltételezzük, hogy a két aktivátor típusú E2F képes lehet kompenzálni a másik hiányát. Az E2FA az E2FB hiányában nem kötődött az E2FB specifikus célgénekhez (CDKB1;1), és nem lépett komplexbe az E2FB-re jellemző fehérje kölcsönható partnerekkel, ezért feltételezzük, hogy az E2FA alternatív útvonalakon képes az E2FB fehérje müködését helyettesíteni. Ezt a feltételezésünket támasztja alá, hogy a két E2F az RBR aktivitását ellenkezőképpen befolyásolja.

6. A fejlödő levélben az E2FB fehérjét gyakorlatilag minden levélsejtben ki tudtuk mutatni, legyen az osztódó, merisztematikus, vagy terminálisan differenciálódó. A meghatározó sejtmagi lokalizáció mellett kimutattuk, hogy az E2FB fehérje a membránhoz kapcsolódva is detektálható. Felfedeztük, hogy kölcsönhat mebránspecifikus fehérjékkel, mint az auxin transzportban szerepet játszó auxin efflux PIN3 és PIN7 fehérjék. Kezdeti eredményeink arra engednek következtetni, hogy az E2FB a PIN3 fehérjével komplexben gátolja annak müködését, és így képes lehet befolyásolni az auxin áramlását és sejten belüli koncentrációját.

Az előttünk álló évtizedekben növelni kell a mezőgazdasági termelést, de már nemcsak élelmezési, hanem energiatermelési célból is. Olyan új biotechnológiai eljárásokat kell fejlesztenünk, amelyek segítségével képesek leszünk fokozni a mezőgazdasági termelést. Ehhez előszőr azokat a szabályozási folyamatokat kell megértenünk, amelyek döntően meghatározzák a növények növekedését. Az általunk leírt eredmények megerősítik azt a nézetet, hogy az E2FRBR molekuláris mechanizmus meghatározó szerepet játszik a végső sejtszám kialakításában, és így a növények növekedésében. Ennek a szabályozási mechanizmusnak a jobb megértése pedig hosszú távon lehetőséget biztosíthat, hogy a növényi termelést elönyös módon változtassuk meg. 


\section{SUMMARY}

In the current cell cycle model, the E2F transcription factors are essential regulators of cell cycle entry as they are believed to exclusively activate cell cycle genes. In model plant Arabidopsis there are two activator E2Fs, E2FA and E2FB, which are proposed to redundantly regulate cell cycle genes. In Arabidopsis however, the simple classification of E2Fs as activators and repressor is mostly based on overexpression studies in plant cell cultures and in transgenic lines and lacks in vivo validation. During my Ph.D. work I have systematically analysed the function of activator E2FB in various transgenic lines including different T-DNA insertion e2fb mutants, dominant negative overexpression lines and in Arabidopsis plants, where E2FB protein could be monitored during organ development in its own expression domain. We have followed gene expressions, purified E2FB containing protein complexes, identified interaction partners and analysed mutant phenotypes as the consequence of modified E2FB activities. We have focused on the function of E2FB in developing leaf as it is a great model system for organ development. Based on these studies, we could draw the following conclusions:

1. We confirmed that E2FB is closely regulated by RBR. Increased E2FB level, caused either by expression driven by its own promoter or by ectopicall overexpression together with DPA, has further elevated the amount of E2FB-RBR repressor complex, leading to reduced cell number and smaller leaf.

2. We found that elevated and ectopic overexpression of E2FB leads to increased RBR level. This autoregulatory loop enforces repression, which ensures that cell proliferation is kept under control and thus increased E2FB level does not lead to tumorous growth. RBR repression of cell proliferation through inhibiting E2FB is suppressed by RBR phosphorylation, and E2FB positively regulates the regulatory cyclin subunit $(\mathrm{CYCD} 3 ; 1)$ of the RBR-kinase (CDKA;1) as well.

3. By analysing the effect of ectopic co-expression of an E2FB dominant negative mutant $\left(\mathrm{E} 2 \mathrm{FB}^{\triangle \mathrm{RBR}}\right)$ with DPA we observed overproliferation of small cells, likely belonging to the stomata lineage in the leaf epidermis. Accordingly, E2FB could function as co-repressor in complex with RBR in cell type specific manner in the developing leaf.

4. The protein levels of both E2FB and RBR decline as leaf development proceeds. During this transition phase from cell proliferation to differentiation, the E2FB-RBR complex is important for exiting cell proliferation and to establish quiescence. When E2FB escapes from RBR repression after the transition phase, differentiated cells reenter cell division, which is the 
case when E2FB level is elevated with expression driven by its own promoter. Accordingly, E2FB could function either as activator or repressor in leaf cells depending on the developmental stage.

5. Reduced expression of cell cycle genes in E2FB mutants was not manifested at their corresponding protein levels, indicating the implication of compensatory mechanism. We found negative correlation between the protein levels of E2FA and E2FB, and they have different impact on the level and activity of RBR protein. In $e 2 f b$ mutant, E2FA protein neither binds to E2FB targets, nor associates with its specific interactors. Our data indicate that they could compensate each other but not through direct substitution.

6. E2FB protein was detected predominantly in the nucleus of nearly all leaf cells regardless whether they were proliferating or differentiating. Interestingly, we observed the association of E2FB protein with the plasma membrane as well. We discovered that E2FB forms complex with membrane proteins including auxin efflux PIN3 and PIN7. Our data indicate that E2FB could influence the activity of PIN3, and therefore could have an impact on the transport of auxin, and could regulate the cellular concentration of this plant growth hormone.

In the following decades, the global market for plant-derived products is expected to expand exponentially. Not only we do rely on plants to feed the growing world population, but plants will also play a pivotal role in providing a significant part of our increasing energy demands. Therefore it is paramount to advance plant biotechnology to further boost biomass production and crop yield. To do this effectively, it will be necessary to understand how the molecular machinery that determines yield parameters operates. Our data further confirm that the E2F-RBR molecular mechanism plays central role in the control of plant growth thus providing an entry point to understand and manipulate the growth potential of plants and crops. 


\section{SAJÁT KÖZLEMÉNYEK}

A disszertáció alapját képző közlemények:

1. Öszi E, Papdi C, Mohammed B, Pettkó-Szandtner A, Leviczky T, Molnár E, GalvanAmpudia C, Khan S, Juez EL, Horvath B, Bögre L, Magyar Z (2020) E2FB Interacts with RETINOBLASTOMA RELATED and Regulates Cell Proliferation during Leaf Development. Plant Physiology 182(1):518-53

2. Leviczky T, Molnár E, Papdi C, Őszi E, Horváth GV, Vizler C, Nagy V, Pauk J, Bögre L, Magyar Z (2019) E2FA and E2FB transcription factors coordinate cell proliferation with seed maturation. Development. 26;146(22)

3. Őszi E (2016) A növényi Retinoblasztoma (RB) és az E2FB által szabályozott fejlődési folyamatok tanulmányozása transzgenikus Arabidopsis növényekben. PEME XIII. PhD. Konferencia ISBN: 978-615-5709-00-5, 81-86

\section{A disszertáció alapját képző korábbi dolgozatok:}

1. Őszi E (2016) Az E2FB-RBR transzkripcionális szabályozás szerepe az Arabidopsis fejlődésében. SZTE TTIK Biológia Diplomamunka

2. Ö́szi E (2013) A növényi retinoblasztoma (RBR) funkció E2FB specifikus gátlása transzgenikus Arabidopsis növényekben. SZTE TTIK Biológia Szakdolgozat

\section{Egyéb közlemények:}

1. Natan E, Endoh T, Haim-Vilmovsky L, Flock T, Chalancon G, Hopper JTS, Kintses B, Horvath P, Daruka L, Fekete G, Pál C, Papp B, Öszi E, Magyar Z, Marsh JA, Elcock AH, Babu MM, Robinson CV, Sugimoto N, Teichmann SA (2018) Cotranslational protein assembly imposes evolutionary constraints on homomeric proteins. Nature structural and molecular biology 25(3):279-288 


\section{FÜGGELÉK}

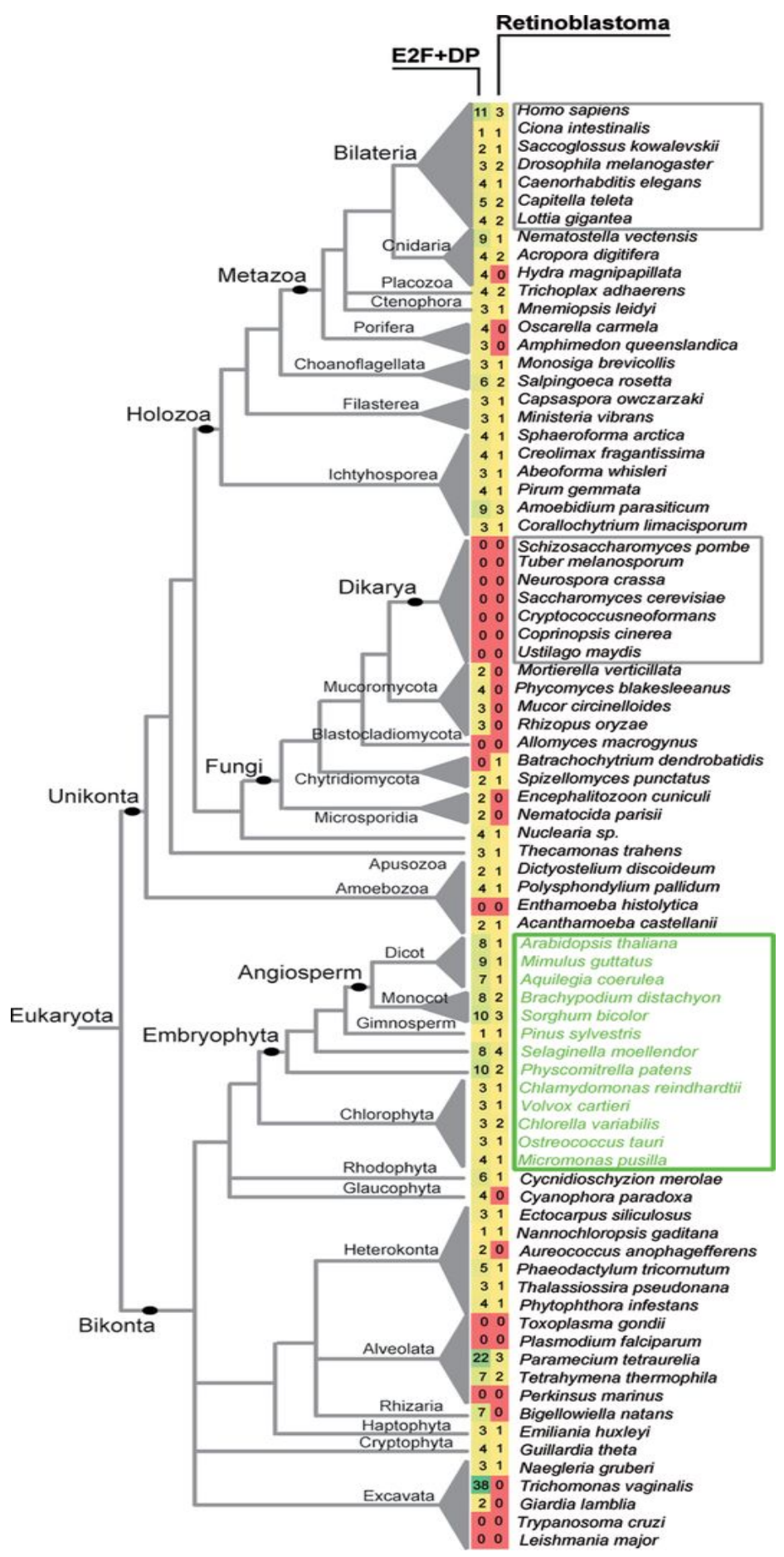

I. ábra. A retinoblasztóma, E2F és DP fehérjék megjelenése az eukarióta evolúció során

$\mathrm{Az}$ eukarióta szupercsoportokat lefedő széles genommintavétel által meghatározott a retinoblasztóma $(R B)$ és az E2F/dimerizációs partner $(D P)$ domének jelenléte, amely PFAMscan felhasználásával készült. (Punta és mtsai., 2012). Az egyes csoportokban a kópiaszám számmal van jelölve. A piros háttér olyan fajokra utal, amelyekben nincs sem $R B$, sem $E 2 F$ vagy $D P$ gén. A sötétzöld háttér azokra a csoportokra utal, amelyekben a legtöbb, a halványzöld, amelyekben a legkevesebb $E 2 F$ és $D P$ gén van. (Desvoyes és mtsai., 2014) 


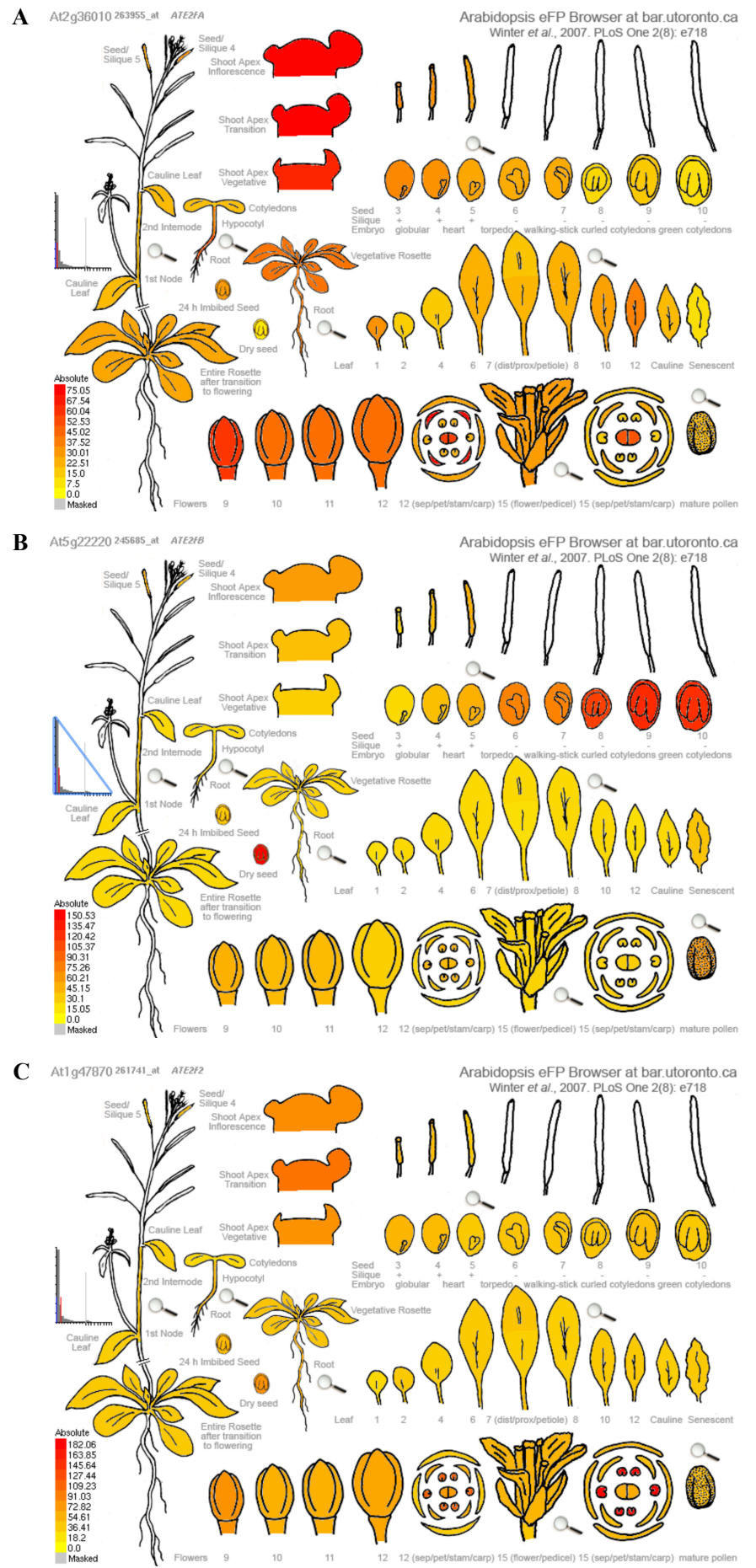

II. ábra. Az E2F gének expressziós mintázata Arabidopsis növény különböző szerveiben

Az eFP browser segítségével ábrázolt A) $E 2 F A$ B) $E 2 F B$ és C) $E 2 F C$ gének expressziós mintázatai (Winter és mtsai., 2007). A fehérből sárgába, narancssárgába majd pirosba hajló színárnyalat fokozatosan erősödő expressziót jelez. 


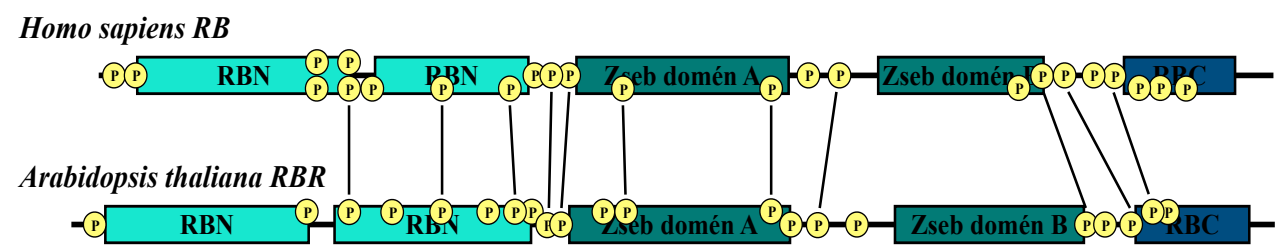

III. ábra. A Homo sapiens és az Arabidopsis thaliana RB fehérjék funkcionális doménjeinek és foszforilációs helyeinek összehasonlító ábrája

A Homo sapiens RB 928, míg az Arabidopsis RBR fehérje 1013 aminosavat számlál, azonban szerkezetük nagy mértékủ homológiát mutat. A sárga hátterü $\mathrm{P}$ jelek a foszforiláció helyeit jelölik, a köztük lévő vonalak a konzervált régiókat jelzik egymásnak megfeleltetve (Dick és Rubin, 2013; Pettkó-Szandtner A, nem publikált eredményei). $($ Mentazöld $=\mathrm{RBN}$, kékeszöld $=$ zseb domén, sötétkék $=\mathrm{RBC}$ régió. $)$

\begin{tabular}{|c|c|c|}
\hline Gén név / régió & Forward primer & Reverse primer \\
\hline ORC2 (AT2G37560) & TCCCGAATCACAACAAACTC & CCACAATAATGGAGGTTGA \\
\hline MCM3 (AT5G46280) & TGGGCAGCACATGAGGAC & CACTTTGTTATCATCTTGCAGTTT \\
\hline CYCA2;3 (AT1G15570) & TCTTGGGAGATCAGCTTCTACAGC & GGCATAGAGGCAGCACAGTAAAGG \\
\hline CYCA3;1 (AT5G43080) & GTCGTACTCGGAGAGCTTCCAAACT & CAGGCATTGTCGCTACACACTTGAA \\
\hline CYCD3;1 (AT4G34160) & GCAGCATAAGTTCAAGTGTGTAGC & AAACCGTAAGAGGCAGCTCTGG \\
\hline CDKB1;1 (AT3G54180) & TCTGTTGGTTGTATCTTTGCTGA & CATTGCTGCTCAGTTGGTGT \\
\hline KRP4 (AT2G32710) & TCGTGGTGATGGGTCTAGGT & GCCAAAGGTTGGATCTTTATTG \\
\hline$R B R(\mathrm{AT} 3 \mathrm{G} 12280)$ & CGCTTCCATTTTGGTTTTGA & TGAACAACAGCAGCAGCAAC \\
\hline E2FA (AT2G36010) & CAACCCAGAAACTGCTATTGTT & GTCCGACTCATCATTTTCAAC \\
\hline$E 2 F C(\mathrm{AT} 1 \mathrm{G} 47870)$ & TGCCGTTATGACAGTTCTTTAGGG & AGTGTTCCATCCTCAGCTTCCT \\
\hline$E 2 F B($ AT5G22220) & GGACCGAGCGACAACAAA & AGGTGATCTCGTAGCAGTGGA \\
\hline UBI10 (AT4G05320) & GGCCTTGTATAATCCCTGATGAATAAG & AAAGAGATAACAGGAACGGAAACATAGT \\
\hline$E 2 F B$ START $e 2 f b-1$ & ATGTCTGAAGAAGTACCTCAA & CTTTCTTGTGATTCTCTGATTTGGT \\
\hline$E 2 F B$ START $e 2 f b-2$ & ATGTCTGAAGAAGTACCTCAA & TGTACTTCATCCTGTAGGTTAGC \\
\hline$E 2 F B$ inszerció $e 2 f b-l$ & ATGTCTGAAGAAGTACCTCAA & TTCATCAGCCTGAGGAATGTC \\
\hline$E 2 F B$ inszerció $e 2 f b-2$ & TCTGCGAAGTCTAATAAGTCTGGA & GTGCCTTTACAGCTATCAGCG \\
\hline
\end{tabular}

B

\begin{tabular}{|c|c|c|}
\hline Gén név & Forward primer & Reverse primer \\
\hline$C D K B 1 ; 1(\mathrm{AT} 3 \mathrm{G} 54180) \mathrm{p} 1$ & CACAGAGGTCACGACTTTAGG & CGCTAAGATACTTCCACGTCAC \\
\hline$C D K B 1 ; 1(\mathrm{AT} 3 \mathrm{G} 54180) \mathrm{p} 2$ & GCTTGCCTATGTTCATGTGG & AGTTCCGCGTTTTGAGACTT \\
\hline$C Y C D 3 ; 1(\mathrm{AT} 4 \mathrm{G} 34160) \mathrm{p} 1$ & CTCTTTTGTAGCTCTCCCCTG & GTTATTGGGTTTTGGCTCAGA \\
\hline$C Y C D 3 ; 1(\mathrm{AT} 4 \mathrm{G} 34160) \mathrm{p} 2$ & AGCCGACAGATTTTACTGCA & TTTCTTTTGCTGTTTCCCGC \\
\hline$C Y C D 3 ; 1(\mathrm{AT} 4 \mathrm{G} 34160) \mathrm{p} 3$ & GGTATCCTCCTCAGCCATCT & ATGGTTGAGGAGGGTAAGCT \\
\hline$R B R(\mathrm{AT} 3 \mathrm{G} 12280) \mathrm{p} 1$ & GGCGAATCTTTCCCTCTCAG & GACACGTACCCATCTGTGAC \\
\hline$R B R(\mathrm{AT} 3 \mathrm{G} 12280) \mathrm{p} 2$ & GGTCCAACTGAAGCAACTGA & ACAGATAGTGTGTGCTAAGCTT \\
\hline ACTIN2 (AT3G18780) & CGCTGACCGTATGAGCAAAG & TTCATGCTGCTTGGTGCAA \\
\hline
\end{tabular}

C

\begin{tabular}{|c|c|c|}
\hline & Hosszú specifikus primer & Rövid nem specifikus degenerált primer \\
\hline PCR I. a & CCTAGAGTCAAGCAGATCGTTCAAACAT & NTCASTWTWTSGWGTT \\
\hline PCR II. & GCATGACGTTATTTATGAGATGGGTTTT & NTCASTWTWTSGWGTT \\
\hline PCR III. & CAAAATATAGCGCGCAAACTAGGATAAAT & NTCASTWTWTSGWGTT \\
\hline PCR I. b & TCACATTAATTGCGTTGCGCTC & NTCASTWTWTSGWGTT \\
\hline
\end{tabular}

\section{I. táblázat. A kísérletek során felhasznált primerek}

Az A) táblázatban találhatóak az RT-qPCR-hoz a B) táblázatban a kromatin immunoprecipitációhoz, míg a C) táblázatban a TAIL-PCR-hoz felhasznált oligonukleotidok. Utóbbinál a PCR I. b-nél vannak azok a primerek feltüntetve, amelyekkel nem kaptunk terméket. 
A

\begin{tabular}{|c|c|c|c|c|c|c|c|c|}
\hline & $\begin{array}{l}\text { levélfelület } \\
\left(\mathrm{mm}^{2}\right)\end{array}$ & $\begin{array}{c}\text { sejtméret } \\
\left(\mu \mathrm{m}^{2}\right)\end{array}$ & $\begin{array}{l}\text { sejtszám / } \\
\text { levél }\end{array}$ & $\begin{array}{l}\text { epidermális } \\
\text { sejtszám / } \\
\text { levél }\end{array}$ & $\begin{array}{l}\text { záró- } \\
\text { sejtszám / } \\
\text { levél }\end{array}$ & $\begin{array}{l}\text { zárósejt } \\
\text { index }\end{array}$ & $\begin{array}{c}\text { extra } \\
\text { sejtosztódás }\end{array}$ & cirkularitás \\
\hline \multirow{2}{*}{ WT } & 1,170 & 149 & 7911 & 6960 & 951 & 0,121 & 27 & 0,625 \\
\hline & $\pm 0,212$ & \pm 15 & \pm 837 & \pm 783 & \pm 83 & $\pm 0,010$ & \pm 12 & $\pm 0,045$ \\
\hline \multirow{2}{*}{$\begin{array}{l}\mathrm{HA}-\mathrm{E} 2 \mathrm{FB} / \\
\mathrm{DPA}^{\mathrm{OE}}\end{array}$} & 0,560 & 106 & 5357 & 4983 & 373 & 0,070 & 8 & 0,758 \\
\hline & $\pm 0,119$ & \pm 12 & \pm 623 & \pm 642 & \pm 20 & $\pm 0,012$ & \pm 14 & $\pm 0,003$ \\
\hline \multirow{2}{*}{$\begin{array}{c}\mathrm{E}^{2} \mathrm{FB}^{\Delta \mathrm{RBR}} / \mathrm{DPA} \\
1\end{array}$} & 0,640 & 144 & 4499 & 3857 & 643 & 0,143 & 21 & 0,674 \\
\hline & $\pm 0,140$ & \pm 11 & \pm 320 & \pm 262 & \pm 60 & $\pm 0,005$ & \pm 19 & $\pm 0,018$ \\
\hline \multirow{2}{*}{$\begin{array}{c}\mathrm{E}_{2} \mathrm{FB}^{\mathrm{ARBR} / \mathrm{DPA}} \\
10\end{array}$} & 0,791 & 166 & 4810 & 3945 & 865 & 0,180 & 18 & 0,668 \\
\hline & $\pm 0,188$ & \pm 19 & \pm 528 & \pm 433 & \pm 102 & $\pm 0,007$ & \pm 16 & $\pm 0,026$ \\
\hline \multirow{2}{*}{ pgE2FB-GFP 72} & 0,702 & 220 & 3219 & 2728 & 491 & 0,152 & 196 & 0,656 \\
\hline & $\pm 0,108$ & \pm 23 & \pm 358 & \pm 279 & \pm 80 & $\pm 0,008$ & \pm 44 & $\pm 0,033$ \\
\hline \multirow{2}{*}{ pgE2FB-GFP 93} & 0,936 & 175 & 5354 & 4678 & 677 & 0,126 & 235 & 0,683 \\
\hline & $\pm 0,151$ & \pm 13 & \pm 400 & \pm 335 & \pm 73 & $\pm 0,006$ & \pm 24 & $\pm 0,018$ \\
\hline \multirow{2}{*}{$e 2 f b-2$} & $1,558 * *$ & 173 & 9169 & 8044 & 1125 & 0,125 & 371 & 0,661 \\
\hline & $\pm 0,314$ & \pm 30 & \pm 1442 & \pm 1473 & \pm 59 & $\pm 0,026$ & \pm 55 & $\pm 0,026$ \\
\hline \multirow{2}{*}{$e 2 f b-1$} & $1,473 * *$ & 184 & 8016 & 6806 & 1210 & 0,150 & 202 & 0,665 \\
\hline & $\pm 0,223$ & \pm 8 & \pm 345 & \pm 400 & \pm 65 & $\pm 0,010$ & \pm 44 & $\pm 0,031$ \\
\hline \multirow{2}{*}{$\begin{array}{l}e 2 f b-2 \text { (pgE2FB- } \\
\text { GFP) } 1\end{array}$} & 1,587 *** & 189 & 8409 & 7172 & 1238 & 0,147 & 186 & 0,657 \\
\hline & $\pm 0,32$ & \pm 13 & \pm 543 & \pm 501 & \pm 45 & $\pm 0,005$ & \pm 57 & $\pm 0,004$ \\
\hline \multirow{2}{*}{$\begin{array}{l}e 2 f b-2 \text { (pgE2FB- } \\
\text { GFP) } 2\end{array}$} & 1,424 * & 193 & 7418 & 6006 & 1412 & 0,192 & 128 & 0,671 \\
\hline & $\pm 0,184$ & \pm 18 & \pm 737 & \pm 845 & \pm 121 & $\pm 0,033$ & \pm 38 & $\pm 0,007$ \\
\hline
\end{tabular}

B

\begin{tabular}{|c|c|c|c|c|c|c|c|c|}
\hline & $\begin{array}{l}\text { levélfelület } \\
\left(\mathbf{m m}^{2}\right)\end{array}$ & $\begin{array}{c}\text { sejtméret } \\
\left(\mu \mathrm{m}^{2}\right)\end{array}$ & $\begin{array}{l}\text { sejtszám / } \\
\text { levél }\end{array}$ & $\begin{array}{l}\text { epidermális } \\
\text { sejtszám / } \\
\text { levél }\end{array}$ & $\begin{array}{l}\text { záró- } \\
\text { sejtszám / } \\
\text { levél }\end{array}$ & $\begin{array}{l}\text { zárósejt } \\
\text { index }\end{array}$ & $\begin{array}{c}\text { extra } \\
\text { sejtosztódás }\end{array}$ & cirkularitás \\
\hline \multirow{2}{*}{ WT } & 11,774 & 724 & 16333 & 9672 & 6661 & 0,408 & 0 & 0,417 \\
\hline & $\pm 2,156$ & \pm 61 & \pm 1434 & \pm 808 & \pm 662 & $\pm 0,011$ & \pm 0 & $\pm 0,021$ \\
\hline \multirow{2}{*}{$\begin{array}{l}\mathrm{HA}-\mathrm{E} 2 \mathrm{FB} / \\
\mathrm{DPA}^{\mathrm{OE}}\end{array}$} & 4,856 ***** & 297 & 16349 & 12237 & 4112 & 0,251 & 0 & 0,557 \\
\hline & $\pm 0,947$ & \pm 1 & \pm 64 & \pm 339 & \pm 368 & $\pm 0,022$ & \pm 0 & $\pm 0,017$ \\
\hline \multirow{2}{*}{$\begin{array}{c}\mathrm{E} 2 \mathrm{FB}^{\mathrm{ARBR}} / \mathrm{DPA} \\
1\end{array}$} & $9,349 *$ & 303 & 31320 & 19429 & 11891 & 0,382 & 0 & 0,589 \\
\hline & $\pm 1,776$ & \pm 46 & \pm 4550 & \pm 3629 & \pm 1179 & $\pm 0,030$ & \pm 0 & $\pm 0,032$ \\
\hline \multirow{2}{*}{ 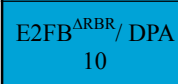 } & 9,906 & 451 & 22330 & 14878 & 7452 & 0,334 & 0 & 0,545 \\
\hline & $\pm 1,976$ & \pm 68 & \pm 3500 & \pm 2444 & \pm 1248 & $\pm 0,027$ & \pm 0 & $\pm 0,016$ \\
\hline \multirow{2}{*}{ pgE2FB-GFP 72} & 6,947 ***** & 537 & 12978 & 9256 & 3723 & 0,286 & 885 & 0,462 \\
\hline & $\pm 1,090$ & \pm 38 & \pm 913 & \pm 337 & \pm 653 & $\pm 0,031$ & \pm 172 & $\pm 0,013$ \\
\hline \multirow{2}{*}{ pgE2FB-GFP 93} & 8,035 ***** & 651 & 12356 & 7416 & 4940 & 0,399 & 50 & 0,431 \\
\hline & $\pm 1,693$ & \pm 30 & \pm 555 & \pm 124 & \pm 520 & $\pm 0,025$ & \pm 87 & $\pm 0,043$ \\
\hline \multirow{2}{*}{$e 2 f b-2$} & $14,571 * *$ & 531 & 27555 & 17601 & 9954 & 0,361 & 0 & 0,493 \\
\hline & $\pm 1,816$ & \pm 37 & \pm 1980 & \pm 1242 & \pm 748 & $\pm 0,004$ & \pm 0 & $\pm 0,012$ \\
\hline \multirow{2}{*}{$e 2 f b-1$} & 13,130 & 583 & 22647 & 13675 & 8972 & 0,398 & 47 & 0,483 \\
\hline & $\pm 2,267$ & \pm 53 & \pm 2160 & \pm 1929 & \pm 450 & $\pm 0,031$ & \pm 48 & $\pm 0,039$ \\
\hline \multirow{2}{*}{$\begin{array}{l}e 2 f b-2 \text { (pgE2FB- } \\
\text { GFP) } 1\end{array}$} & 11,728 & 932 & 12600 & 7296 & 5304 & 0,420 & 30 & 0,423 \\
\hline & $\pm 1,366$ & \pm 34 & \pm 472 & \pm 353 & \pm 463 & $\pm 0,028$ & \pm 27 & $\pm 0,013$ \\
\hline \multirow{2}{*}{$\begin{array}{c}e 2 f b-2 \text { (pgE2FB- } \\
\text { GFP) } 2\end{array}$} & 11,798 & 1172 & 10086 & 5817 & 4270 & 0,423 & 22 & 0,416 \\
\hline & $\pm 1,117$ & \pm 62 & \pm 519 & \pm 105 & \pm 424 & $\pm 0,021$ & \pm 39 & $\pm 0,002$ \\
\hline
\end{tabular}

II. táblázat. Összefoglaló táblázat a vad típusú és transzgenikus növények kinematikai vizsgálata során mért sejtszintü adatokról

Az első valódi levélpárt használtuk a levélfelület meghatározásához A) 8 és B) 12 nappal a csírázást követően. A képanalízist ImageJ program segítségével végeztük. A sejtek felületét, -számát és cirkularitását a levél 3 zónájában megmértük (levél alap, középső régió és levél csúcs), majd ezen eredményekből kiszámoltuk a sejtek átlag méretét, az összsejtszámot, és az epidermális sejtek számát zárósejtek nélkül. A megnövekedett differenciálódott sejtekben kialakuló új sejtfalakat (extra osztódások) a levél mindhárom zónájában leszámoltuk. A transzgenikus vonalak eredményeit a vad típusú növényeken mért adatokhoz viszonyítottuk. (***: $\mathrm{p} \leq 0,001, * *: p \leq 0,01, *: \mathrm{p} \leq 0,05 ; \mathrm{n}>3$, $\mathrm{N}>600$, ahol „n” a biológiai ismétlések száma és „N” a vizsgált sejtek száma / minta). 


\section{NYILATKOZAT}

Mint az alábbi közlemények felelös és/vagy elsö szerzője igazolom, hogy Őszi Erika Ph.D. jelölt jelentős mértékben hozzájárult az alábbi tudományos publikációk létrehozásához és tézisében közölt eredményeit más Ph.D. értekezésben nem használjuk fel.

Öszi E, Papdi C. Mohammed B, Petkó-Szandtner A. Leviczky T, Molnár E, GalvanAmpudia C, Khan S, Juez EL, Horvath B, Bögre L, Magyar Z (2020) E2FB Interacts with RETINOBLASTOMA RELATED and Regulates Cell Proliferation during Leaf Development. Plant Physiology 182(1):518-53

Leviczky T, Molnár E, Papdi C, Öszi E. Horváth GV, Vizler C, Nagy V, Pauk J, Bögre L, Magyar Z (2019) E2FA and E2FB transeription factors coordinate cell proliferation with seed maturation. Development. 26;146(22)

Kelt: Szeged, 2020, október 6.

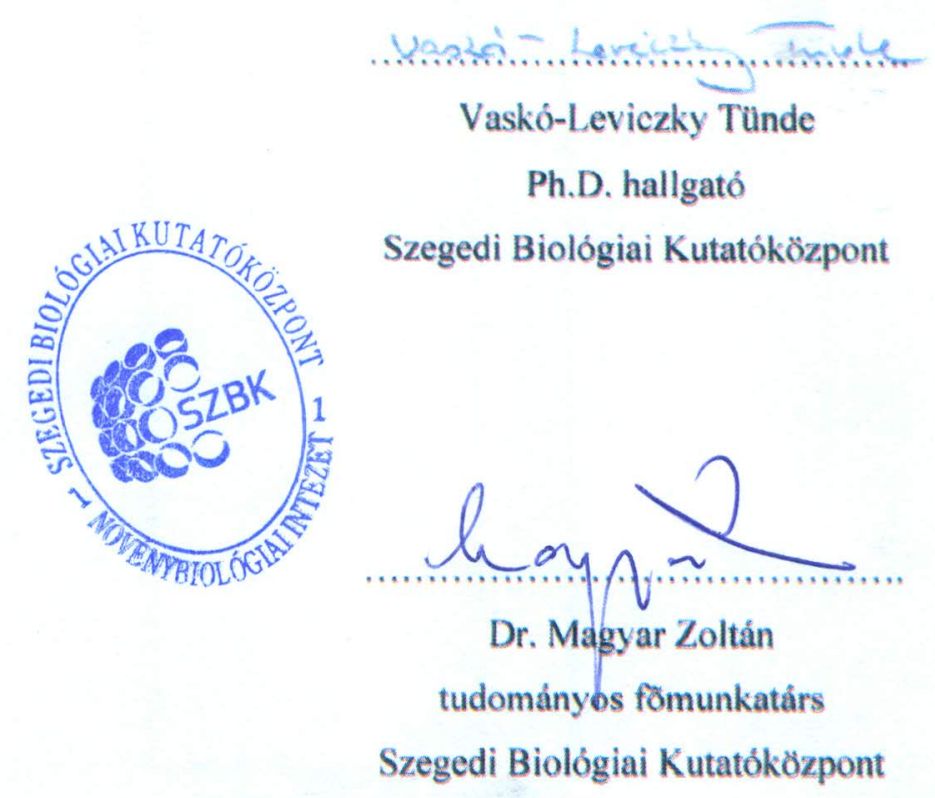

